


\section{Post-Ottoman Coexistence}




\section{Space and Place}

Bodily, geographic, and architectural sites are embedded with cultural knowledge and social value. The Anthropology of Space and Place series provides ethnographically rich analyses of the cultural organization and meanings of these sites of space, architecture, landscape, and places of the body. Contributions to this series examine the symbolic meanings of space and place, the cultural and historical processes involved in their construction and contestation, and how they are in dialogue with wider political, religious, social, and economic institutions.

Volume 1

Berlin, Alexanderplatz: Transforming

Place in a Unified Germany

Gisa Weszkalnys

Volume 2

Cultural Diversity in Russian Cities: The

Urban Landscape in the post-Soviet Era

Edited by Cordula Gdaniec

Volume 3

Settling for Less: The Planned Resettlement of Israel's Negev Bedouin

Steven C. Dinero

Volume 4

Contested Mediterranean Spaces:

Ethnographic Essays in Honour of Charles Tilly

Maria Kousis, Tom Selwyn, and David Clark

Volume 5

Ernst L. Freud, Architect: The Case of the Modern Bourgeois Home

Volker M. Welter

Volume 6

Extreme Heritage Management:

The Practices and Policies of Densely

Populated Islands

Edited by Godfrey Baldacchino

Volume 7

Images of Power and the Power of Images: Control, Ownership, and Public Space

Edited by Judith Kapferer

Volume 8

Performing Place, Practising Memories: Aboriginal Australians, Hippies and the

State

Rosita Henry

Volume 9

Post-Cosmopolitan Cities: Explorations of

Urban Coexistence

Edited by Caroline Humphrey and

Vera Skvirskaja
Volume 10

Places of Pain: Forced Displacement,

Popular Memory and Trans-local

Identities in Bosnian War-torn

Communities

Hariz Halilovich

Volume 11

Narrating Victimhood: Gender, Religion

and the Making of Place in Post-War

Croatia

Michaela Schäuble

Volume 12

Power and Architecture: The Construction of Capitals and the Politics of Space

Edited by Michael Minkenberg

Volume 13

Bloom and Bust: Urban Landscapes in the East since German Reunification

Edited by Gwyneth Cliver and

Carrie Smith-Prei

Volume 14

Urban Violence in the Middle East:

Changing Cityscapes in the

Transformation from Empire to

Nation State

Edited by Ulrike Freitag, Nelida Fuccaro,

Claudia Ghrawi and Nora Lafi

Volume 15

Narrating the City: Histories, Space, and

the Everyday

Edited by Wladimir Fischer-Nebmaier,

Matthew P. Berg, and Anastasia Christou

Volume 16

Post-Ottoman Coexistence: Sharing Space in the Shadow of Conflict

Edited by Rebecca Bryant 


\title{
Post-OtToman COEXISTENCE
}

Sharing Space in the Shadow of Conflict

\author{
$2 \cdot \cdot 6$ \\ Edited by \\ Rebecca Bryant
}

berghahn 
First published in 2016 by
Berghahn Books
www.berghahnbooks.com

(C)2016 Rebecca Bryant

All rights reserved. Except for the quotation of short passages for the purposes of criticism and review, no part of this book may be reproduced in any form or by any means, electronic or mechanical, including photocopying, recording, or any information storage and retrieval system now known or to be invented, without written permission of the publisher.

\section{Library of Congress Cataloging-in-Publication Data}

Names: Bryant, Rebecca (Professor of anthropology) editor.

Title: Post-Ottoman coexistence : sharing space in the shadow of conflict / edited by Rebecca Bryant.

Description: New York : Berghahn Books, 2016. | Series: Space and place ; 16 Identifiers: LCCN 2015036431| ISBN 9781785331244 (hardback : alk. paper) | ISBN 9781785331251 (ebook)

Subjects: LCSH: Turkey-Social conditions-20th century. | Turkey-Social conditions-21st century. | Middle East-Social conditions-20th century. | Middle East-Social conditions-21st century.

Classification: LCC HN656.5.A8 P67 2016 | DDC 306.09561-dc23

LC record available at http://lccn.loc.gov/2015036431

British Library Cataloguing in Publication Data

A catalogue record for this book is available from the British Library

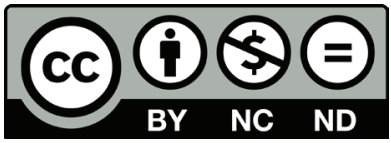

This work is published subject to a Creative Commons Attribution Noncommercial No Derivatives 4.0 International license. The terms of the licence can be found at https://creativecommons.org/licenses/by-nc-nd/4.0/.

For permission to publish commercial versions please contact Berghahn Books.

ISBN: 978-1-78533-124-4 (hardback)

ISBN: 978-1-78533-125-1 (ebook)

ISBN: 978-1-78533-375-0 (open access ebook) 


\section{Contents}

List of Illustrations vii

Acknowledgments ix

Introduction. Everyday Coexistence in the Post-Ottoman Space 1 Rebecca Bryant

\section{Part I. Landscapes of Coexistence and Conflict}

Chapter 1. Sharing Traditions of Land Use and Ownership: Considering the "Ground" for Coexistence and Conflict in Pre-modern Cyprus

Irene Dietzel

Chapter 2. Intersecting Religioscapes in Post-Ottoman Spaces: Trajectories of Change, Competition, and Sharing of Religious Spaces

Robert M. Hayden

Chapter 3. Cosmopolitanism or Constitutive Violence?

The Creation of "Turkish" Iraklio

Aris Anagnostopoulos

Chapter 4. Trade and Exchange in Nicosia's Shared Realm:

Ermou Street in the 1940s and 1950s

Anita Bakshi

\section{Part II. Performing Coexistence and Difference}

Chapter 5. In Bed Together: Coexistence in Togo Mizrahi's Alexandria Films

Deborah A. Starr

Chapter 6. Memory, Conviviality, and Coexistence: Negotiating Class Differences in Burgazadası, Istanbul

Deniz Neriman Duru

Chapter 7. "If You Write This Tačno, It Will Be Točno!":

Language Ideologies and Linguistic Practices in Postwar Bosnia and Herzegovina*

\section{Azra Hromadžić}


Part III. Negotiating Everyday Coexistence in the Shadow of Conflict

Chapter 8. The Istanbul Armenians: Negotiating Coexistence 207

Sossie Kasbarian

Chapter 9. A Conflict of Spaces or of Recognition? Co-presence in Divided Jerusalem

Sylvaine Bulle

Chapter 10. Grounds for Sharing-Occasions for Conflict:

An Inquiry into the Social Foundations of Cohabitation and Antagonism

Glenn Bowman

Index 


\section{Illustrations}

Figure 2.1. Minaret on the fourteenth century St. Nicholas Church in Famagusta, Cyprus, converted into a mosque after the Ottoman conquest in the sixteenth century. Aya Sofya mosque until 1954, then renamed Lala Mustafa Paşa Mosque (photo by Robert M. Hayden, October 2011).

Figure 2.2. St. Nicholas Church, Chania, Crete. Venetian fourteenth century Catholic church, converted into a mosque by Ottomans in 1645, then into a Greek Orthodox church in 1918. Note truncated minaret (photo by Robert M. Hayden, May 2015).

Figure 4.1. "View Near St. Sophia - Late 1950s." The main municipal market Pantapolio/Bandabulya appears in the background. Photograph from The Press and Information Office Archive, 20C.151 (27), Ministry of the Interior, Republic of Cyprus. 117

Figure 4.2. A portion of the map created through discussions and mapping sessions with the shopkeepers. Köprü Başı / Stavro Pazaro was a major landmark in the city and many shopkeepers were able to recall shops that once were located in this part of the city.

Figure 5.1. Chalom and ${ }^{\mathrm{c} A b d u}$ wake up together in bed.

Screenshot, Mistreated by Affluence (1937).

Figure 5.2. Hilmy disguised as "Dr. Hilmy." Screenshot, Doctor Farahat (1935).

Figure 5.3. Hilmy disguised as "Mustafa," with Nona. Screenshot, Doctor Farahat (1935).

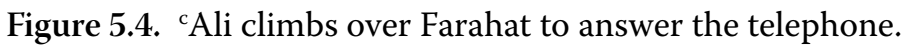

Screenshot, Doctor Farahat (1935).

Figure 5.5. Farahat and Umm Ahmad in bed. Screenshot, Doctor Farahat (1935).

Figure 5.6. Nona and Tahiya in bed. Screenshot, Doctor Farahat (1935). 
Figure 5.7. Tahiya watches Nona undress. Screenshot, Doctor Farahat (1935).

Figure 5.8. Chalom and 'Abdu kiss. Screenshot, Mistreated by Affluence (1937).

Figure 5.9. Driver watches Chalom and ${ }^{\mathrm{c} A b d u}$ kiss. Screenshot, Mistreated by Affluence (1937).

Figure 7.1. Mostar Gymnasium (photo by Azra Hromadžić, June 2012).

Figure 9.1. Confrontation in Jerusalem: Mt. of Olives and East Jerusalem (photo by Sylvaine Bulle).

Figure 9.2. East Jerusalem (photo by Sylvaine Bulle). 


\title{
Acknowledgments
}

\begin{abstract}
S conference "Shared Spaces and their Dissolution: Practices of Coexistence in the Post-Ottoman Sphere," organized by the Peace Research Institute Oslo's Cyprus Centre, the Association for Historical Dialogue and Research, and the Friedrich Ebert Stiftung, with funding from the Chrest Foundation, the National Bank of Greece, and the London School of Economics Research on Southeast Europe Programme. We are grateful to these funders, as well as to the PRIO Cyprus Centre for its generous support of the book project.

Some portions of Azra Hromadžić's chapter appeared in her monograph, Citizens of an Empty Nation: Youth and State-Making in Postwar Bosnia and Herzegovina. We are thankful to the University of Pennsylvania Press for permission to publish a revised version of this chapter.
\end{abstract}





\title{
Introduction
}

\author{
Everyday Coexistence in the Post-Ottoman Space
}

\author{
REBECCA BRYANT
}

In 1974 they started tormenting us, for instance we'd pick our apples and they'd come and take them right out of our hands. Because we had property we held on as long as we could, we didn't want to leave, but finally we were afraid of being killed and had to flee... We weren't able to live there, all night we would stand by the windows waiting to see if they were going to kill us.... When we went to visit [in 2003, after the checkpoints dividing the island opened], they met us with drums as though nothing had happened. In any case the older elderly people were good, we used to get along with them. We would eat and drink together.

-Turkish Cypriot, aged 89, twice displaced from a mixed village in Limassol district, Cyprus

$\mathrm{I}_{\mathrm{n}}$ In a sophisticated portrayal of the conflict in Cyprus in the 1960s, Turkish Cypriot director Derviş Zaim's feature film Shadows and Faces (Zaim 2010) shows the degeneration of relations in one mixed village into intercommunal violence. Zaim is himself a displaced person, and he based his film on his extended family's experiences of the conflict and on information gathered from oral sources. Like anthropologist Tone Bringa's documentary We Are All Neighbours (Bringa 1993), filmed at the beginning of the Yugoslav War and showing in real time the division of a village into warring factions, Zaim's film emphasizes the anticipation of violence and attempts to show that many people, under the right circumstances, could become killers. The film also shows, however, an aspect of that cycle of violence that I often recorded in interviews with Turkish Cypriots displaced during the period: namely, an emphasis on fear but also very often the mention of "old people" who tried to hold things together. 
The epigraph above highlights this, as the speaker, displaced twice over the period of a decade, emphasizes that "the older elderly people were good, we used to get along with them." He uses the phrase eski yaşlı insanlar, the "older elderly people," to indicate not relative age today, but rather that these were people who were already mature, perhaps in late middle age, by the time of the occurrences he describes. In Zaim's film as well, the degeneration into violence is provoked by the actions of a few hotheaded youths, even as the older men and women of the village try to maintain calm and where possible to use relations or connections with police and paramilitaries to prevent the violence from spreading to their own streets. Zaim shows how the more mature members of each community engaged in everyday forms of diplomacy that wove the fragile quotidian fabric of village life. Similarly, in Bringa's documentary Croatian and Muslim women continue to visit and drink coffee together even as their region is on the brink of war. While Bringa's documentary shows how encroaching violence forces neighbors to take sides, Zaim's historical feature film demonstrates how the devolution into violence may be triggered by a few rash actions that create mistrust and hostility and rend the fabric of village life.

Moreover, both the epigraph above and the two films make reference to commensality, a theme often invoked by those who lived in mixed villages. In my own interviews with both Greek Cypriots and Turkish Cypriots who lived in mixed villages, I often heard that "we would eat and drink together" or "we attended each other's weddings" (see Bryant 2010, 2012; also Argyrou 1996). Since commensality is not mentioned in reference to intra-group contact, its invocation already marks this as inter-group contact, implying the unexpected or exceptional. In this circumstance, the invocation of commensality implies a difference overcome through the ritual practice of breaking bread. Women visited each other for coffee, though such rituals were circumscribed by proximity and therefore tended to be limited by the composition of neighborhoods. Meals were shared at weddings, and men drank together in the coffeehouses, although very few accounts speak of sharing food at home, and even more rarely eating together during religious holidays or funerals. Indeed, these instances of commensality appear in many cases to bear resemblance to the "gastronomic diplomacy" discussed by Costas Constantinou (1996) as an important method and ritual for keeping the peace that has been employed throughout the world and throughout human history.

The "shared spaces" of the volume's title are those places where persons of different faiths and ethnic groups lived and worked side by side, where they felt under some moral obligation to attend each other's wed- 
dings and festivals. "Shared spaces" may be religious sites with meaning for more than one confessional group; the market, mine, or other site of economic activity; or the common space of the mixed village or urban neighborhood.

Shared spaces may be characterized by political, economic, or social cooperation or antagonism. The everyday cooperative practices that enable the sharing of space may entail friendship or simple pragmatic accommodation. While these were obviously "places" endowed with specific historical and social meanings to the persons who lived in them, we refer to them here as "spaces" to indicate simple geographical closeness, where it was precisely the meanings of those spaces as places that so often became a source of antagonism and conflict (see Hayden and Bowman this volume). Beginning in the nineteenth century, the spread of nationalisms throughout the Ottoman Empire led to everyday ways of (re)claiming spaces, through renaming sites and streets, destroying and building monuments, and other territorial practices. Throughout Southeast Europe and the Middle East, many former spaces of interaction are now sites of past violence and are marked by the absence of groups who had once lived there. Post-Ottoman spaces are today palimpsests of the social memory of violence, where persons attempt to live together under the shadow of past coexistence and the conflict that rended it.

We know that coexistence in pre-nationalist Southeast Europe involved more than simply living side by side, and that there were rituals of accommodation that simultaneously defined and crossed boundaries. But we piece together this past from fragments of information, and ones that today are heavily laden with the ideological baggage of ongoing conflicts-as in cases such as Cyprus-or unresolved histories, such as in Bosnia, Turkey, and other case examples included in this volume. In such instances, "living together" has significant historical and political implications. Ideology, in turn, gives shape to memory, either nostalgically tinting the past with a rosy glow or painting it as an era of constant conflict.

"Coexistence" is a term that acquires special relevance and meaning when it is no longer possible. The search for an "Ottoman model" for coexistence, for instance, begins retrospectively, after the disintegration of the empire in the wake of Balkan and Arab nationalisms and the ethnic cleansing of Anatolia. ${ }^{1}$ Similarly for South Asia, where a literature has emerged in recent decades that explores the events leading to Partition and Hindu-Muslim tensions today that have resulted in periodic riots. While these and other similar literatures are in some ways case-specificfor instance, "the riot" as a concept does not exist for the Ottoman and post-Ottoman literature ${ }^{2}$ - what they share is an attempt to understand 
the forces that drive us apart by looking at those forces that in the past have held us together. Much as nostalgia emerges from irretrievable loss, so "peaceful coexistence" emerges from violence that appears irreparable. This is, no doubt, why discussions of coexistence often struggle against the rosy tinge that often envelops nostalgic images of the past. ${ }^{3}$

If many people in Southeast Europe and the Middle East today mourn past pluralism, it is in the wake and under the influence of that pluralism's destruction. The post-Ottoman space is one where the Ottoman millet system that defined difference along religious lines became the basis for the peculiar binding of nationalism and religion in the postOttoman period (see, e.g., Grigoriadis 2012; Leustean 2014; Yosmaoğlu 2014). It is also a space that experienced the twentieth century's first massive displacement, movement, and exchanges of peoples, as nationstates attempted to homogenize populations within newly drawn borders. That homogenization was never complete, leaving minority "remainders"-Muslims in Greek Thrace, Orthodox and Armenians in Turkey-who also served as reminders of the violence that had destroyed previous ways of living together and reduced substantial populations to non-threatening numbers. The post-Ottoman space, then, is defined both by the legacy of pluralism and by the enduring puzzle of its violent dissolution.

As I discuss in more detail below, the multi-religious, multi-ethnic Ottoman Empire was a state organized around the management and appreciation of difference. As a result of these arrangements and their violent splintering into nation-states, coexistence has acquired a special meaning in the Ottoman and post-Ottoman context to refer to everyday, horizontal relations among persons belonging to different ethnic or confessional groups. One common assumption in the historical literature is that something that might be called coexistence existed and was operative before the divisions produced by nationalist ideologies and nation-state projects. As a result, "coexistence" has become the conceptual and historical background against which violence unfolds.

Indeed, much of the literature to date conceptually exploring coexistence within the anthropology of the region has primarily addressed the extent to which some form of conflict was or was not latent in the intercommunal quiet of the pre-nationalist everyday. ${ }^{4}$ The spectrum from antagonism to amity has been especially well represented by two contributors to this volume, Robert Hayden and Glenn Bowman. Hayden refers to the "robustness of boundaries" between religious groups, seen in "differences such as in naming, kinship terminology, marital endogamy, places and methods of burial, diet, dress, education, and perhaps preferred methods of gaining a livelihood" (Hayden and Walker 2013: 
401). Moreover, in the model of "antagonistic tolerance" that Hayden has developed with numerous co-authors, he argues that "there is 'tolerance' in the Lockean sense, of enduring the presence of the other but not embracing it, so long as one group is clearly dominant over others" (Ibid.: 402). Hayden claims that such tolerance perdures as long as one group has clear dominance over another, and he argues for a longue durée perspective that will allow us to situate moments of peaceful interaction within the long-term relations of dominance between groups (especially Hayden and Walker 2013; Tanyeri-Erdemir, Hayden, and Erdemir 2014; Hayden this volume).

Bowman, on the other hand, taking issue with "Hayden's concept of the incommensurability of cultures," instead stresses "moments of apparent amity" (Bowman 2013: 2) and the variety of ways in which "boundaries are variously reinforced, opened, and transgressed" (Ibid.: 13). Bowman emphasizes the porosity of popular religious practice that allows it to be suffused with non-orthodox elements, including those of other faiths, when they appear to be efficacious. While Hayden argues that Bowman's work is commensurate with his own thesis in that it shows a recognition of religious difference and is synchronic but may change over time (see Hayden this volume), Bowman views their positions as fundamentally incompatible. Indeed, in this debate, those who take the stronger "difference" position and see quotidian antagonism have been equated with identitarian, nationalist ideologues, or the "clash of civilizations" perspective, ${ }^{5}$ while those who make arguments for the importance of commonalities are often accused of wishful thinking, of projecting their own desires onto the pasts of others. ${ }^{6}$ This debate is representative of a continuing conceptual deadlock within the literature regarding what difference has meant in the Ottoman and post-Ottoman contexts.

Moreover, at least three methodological problems await the researcher attempting to examine coexistence, especially past coexistence affected by conflict. The first is the simple dearth of sources, since coexistence represents the practices of everyday life that rarely find their way into the records, as opposed to the "events" that construct archives and define historical study. ${ }^{7}$ As Nicholas Doumanis in his own examination of pre-nationalist intercommunality remarks, "Intercommunality was designed to produce the kind of history that Hegel likened to a blank page. It militated against the possibility of 'events,' which are the grist of conventional history writing" (Doumanis 2012: 2). This does not mean that we are without records: for instance, the literature on the Ottoman neighborhood uses court documents of formal and informal conflict resolution to assess living together as a way of maintaining communal 
peace (sulh). While such history has only minimal means for understanding perceptions of difference or the texture of relationships, it does help us to understand the mechanisms by which sulh was maintained. Through its "uneventfulness," then, coexistence is by nature self-effacing, though I argue below that there is much to learn from the practices that accomplish its historical disappearance.

The second is the danger of projecting present categories and concerns onto the past, or attempting to define coexistence through the lens of concepts used today such as multiculturalism. Doumanis, for instance, claims that the problem of different groups living together, or the problem of difference per se, is one created in Western Europe and spread to other parts of the world during the era of Western colonialism. ${ }^{8}$ Aron Rodrigue has argued that the problem of difference emerged with post-Enlightenment ideas of majority/minority, and their inflection in a public sphere, where otherness must be "accommodated" (Rodrigue 1996). Indeed, our own contemporary inability to conceptualize difference beyond "identity" and its presumed boundaries continually returns us to the problem of "reconciling" such cultural identities-a problem represented most clearly in the "clash of civilizations" literature, which presumes the irreconcilability of cultural identities. ${ }^{9}$ Indeed, "identity" has perhaps been the most troublesome concept for understanding coexistence, as it demands reification where there may be none, ${ }^{10}$ and in popular literature "peace" is often equated with having the same "identity"-even where the presumption of such an identity is clearly a result of power relations that occlude minority claims. ${ }^{11}$

In a similar vein, current popular nostalgia for a multicultural past may mask denial of the ways in which that multiculturalism was destroyed. Focusing on one neighborhood in Istanbul, Amy Mills shows that the "disguising power of nostalgia," viewed in a landscape dotted with the remnants of Greeks, Armenians, and Jews, occludes how those communities ceased to exist in the present (Mills 2011: 190). In his contribution to this volume, Aris Anagnostopoulos shows how it was actually the disappearance of Muslims from Iraklio in Crete that made it possible to become nostalgic about a multicultural past (see also Kasbarian this volume). In this sense, as Mills comments, the moral values of tolerance and cosmopolitanism work to disguise power, presenting "elite ... visions of history that paradoxically refer to minorities even while they obscure minority perspectives of history" (Ibid.). In her study of plurality in contemporary Poland, Agnieszka Pasieka (2014) refers to this highly idealized and nostalgic view of a "lost paradise" and past "harmony" as the "multiculturalization" of the past, which she believes disguises the tensions of actual living together. Concomitantly, such nostalgia may draw 
attention away from current discriminatory practices against minorities, many of whom are immigrants. As Nora Lafi observes,

Mediterranean cities do not seem to be sponsoring the invention of a new cosmopolitan ideal. The present situation, in which uses of cosmopolitanism are more often ideological decoys than genuine innovations in terms of governance of diversity, draws on a limited vision of the cosmopolitan past of some cities of the region. (Lafi 2013: 331-32)

Rather than engaging fully with a cosmopolitan ideal, in which many residents of especially port cities in the past saw themselves as "citizens of the world" (Driessen 2005), this popular nostalgia instead is used to valorize one's own tolerance and in Turkey has been part and parcel of a neo-Ottoman revival (see Onar 2009).

A third problem, which follows from the first two, is recognizing "coexistence" when one sees it. For instance, is coexistence simply noninterference, or is it a way of actively managing difference? Does coexistence require common goods or aims? Does it include or exclude violence? What we can say with some certainty is that coexistence is a form of sociality, a way of living together and defining belonging and the meaning of its boundaries. Clearly, for the process of living together, and for anyone wishing to study this process, what is important is both the porosity or impassibility of those boundaries, as well as how we understand the implications of what they contain.

Various authors in this collection tackle this latter problem through terms that speak to other affective or experiential facets of living with difference and negotiating boundaries. Deniz Duru uses "conviviality" to describe the ways in which place may be created for those who live in it through the norms and patterns of a shared lifestyle that actively values pluralism and that they consider to be different from the norms of the larger society. This analysis emphasizes the self-conscious making of pluralism, using the Spanish convivència, or "a shared life," which has been recently taken up as policy by local governments in Spain (see Heil 2014) and has been described as "an exercise of negotiation that assumes difference as a basic fact of life and the need to make room for dialog among all members of society, respect for one another, and sharing the public social sphere" (Suárez-Navaz 2004: 191f).

Contrary to the term "coexistence," which appears to imply passively "existing" together, terms such as conviviality emphasize the performative nature of boundary-crossing and the conscious or self-conscious value attached to living with difference. While Duru describes the role of conviviality in making Burgaz Island in Istanbul a place defined by its plurality, 
Deborah Starr shows how what she calls a "Levantine idiom" defined by identity fluidity may be performatively produced. Both these chapters call attention to the relationship between plurality and place-making, "an urban localism characterized by diversity" (Starr this volume). Being a Burgazlı or a Levantine was also a matter of self-consciously making one's own neighborhood or local identity through the performance of pluralism.

Other authors think with ideas of cohabitation or co-presence, concepts that describe sharing space especially in urban environments, as something that may require not the sort of active social interaction described by Duru and Starr but rather inattention or giving way. Sylvaine Bulle describes this as "a mode of living together based on an indifference toward communitarianism and respect for private life" (Bulle this volume). This is the form of coexistence in which we "live and let live," or when in urban spaces we share trains and sidewalks with persons who may be identifiably Other. As Bowman points out, this form of sharing puts emphasis on space rather than place: while the former may be defined by simple "civil inattention" (Goffman 1971), the latter is defined by "giving ground" (Bowman this volume). As Bulle suggests, however, such encounters may also create a foundation for mutual engagement and civic action. Describing these as "communities of confidence," Bulle employs Simmel's idea of "the stranger," someone who has general but not specific similarities to us, as a way to understand this ability to share space. Anita Bakshi's chapter similarly gives us insight into such "communities of confidence" in the marketplace of central Nicosia, a place defined by intercommunal interaction distinct from the primarily monocommunal interaction of the neighborhood. However, Bakshi employs Simmel's stranger also to warn that such everyday interactions usually are not capable on their own of surviving incidents of intercommunal violence.

"Coexistence," then, implies recognition of boundaries but also acknowledges that such boundaries are negotiable and that they allow us in some sense still to live together. While recognizing the limitations of coexistence as a term, we use it here as an umbrella for understanding ways of living with acknowledged difference. We qualify this here, however, as "everyday coexistence," the form of coexistence produced through proximity, to distinguish it from the legal, political, and discursive forms of coexistence that imply the "living together" of millets or ethnic groups within the empire or nation. As I discuss below, geography plays an important role in the ways that modes of living together are negotiated and enacted, especially in the form of what I refer to as multi-scalar sovereignty, experienced as territoriality or territorialization in the enactment of local relations. 
In what follows, then, I draw upon chapters in this volume and the literature on Ottoman and post-Ottoman coexistence to think about the negotiations of everyday life in the post-Ottoman space. Building on this discussion, I then argue that the anthropology and history of the region would benefit from greater conceptual engagement with theories of sovereignty and everyday diplomacy in its studies of everyday interactions involving the proximity of persons understood to be different. As I discuss below, the norms of hospitality and neighborliness that guide interactions in the settings under discussion in this volume are both formalized and embedded within multiple scales of sovereign domain. And while anthropology has long examined the rituals and exchanges of war and peace, there has been little attempt to incorporate recent literature on what Costas Constantinou calls "homo-diplomacy" into the study of quotidian relations (Constantinou 2006). Below I discuss studies of coexistence in the Ottoman and post-Ottoman space in order to make a case for more attention to the role of territoriality, sovereignty, and everyday diplomacy in local socialities.

I then turn to a discussion of the volume's chapters in order to argue for a particular way of understanding everyday coexistence that I believe helps clear some of the conceptual muddle that currently befuddles the field. Bracketing discussions of antagonism or amity, I instead describe everyday coexistence as the labor of peace, including the sorts of conflict resolution mechanisms that maintained sulh, as well as the constant, everyday practices of accommodating each other that maintained huzur. While sulh tends to be used to refer to peace as that which contrasts with conflict, huzur refers to peace as tranquility and calm, the sort of peace that is broken not by violence but by the daily disruptions and tensions of the neighborhood-making too much noise, or disrespecting one's neighbors. "Sulh might occur in any mahalle or village," notes historian Ronald Jennings, "and the negotiation of sulh was a neighborly process, not a formal legal procedure" (Jennings 1978: 148). While sulh might be seen as a type of informal conflict resolution, the maintenance of huzur in the neighborhood is achieved both through the rituals of sociality and through the management of tension in everyday interaction and exchange (see also Ring 2006).

\section{The Historiography of Ottoman Coexistence}

In the wake of war and social upheaval, certain symbols have acquired the cache of representing "peaceful coexistence." One of the most famous of these is the Mostar Bridge. During the Yugoslav war it became 
symbolic of the savageness that rends peoples, and after the war was reconstructed with the express purpose of demonstrating "that the connections between Bosnia's people were being rebuilt, too" (Hayden 2007: 108; see also Hromadžić this volume). As Hayden emphasizes, the bridge was celebrated as a symbol of reunification even as Muslims and Croats in the city were keeping to their own sides of the river. Similarly in $\mathrm{Cy}-$ prus, images of minaret and church bell tower side-by-side were used by the government of the Republic of Cyprus after 1974 to represent a new discourse of peaceful coexistence that had supposedly been shattered by Turkey's invasion and division of the island.

However, Mete Hatay (2011) has shown that minarets and bell towers in the island proliferated in the age of nationalisms, as a competitive way of imprinting one's ethnic presence on the landscape. Moreover, this discourse of peaceful coexistence intentionally occludes the conflict period between 1963-74 (Constantinou and Papadakis 2001) when Turkish Cypriots were disproportionately the victims. In a similar way, nostalgia for multiculturalism in Turkey occludes the way that multiculturalism was destroyed, although Doumanis (2012: 2) urges us not entirely to dismiss the content of nostalgia for this reason.

What is clear, however, is that in the post-Ottoman context, discourses of peaceful coexistence imply a selective archeology of cultural ruins. This region, stamped by pogroms, large-scale population movements, erasures, and reinscriptions, is one in which past coexistence is hidden under conceptual accretions and in which present coexistence is troubled by conflict histories. Moreover, "coexistence" as discourse has often become a tool for denial. In Cyprus and Bosnia, for instance, past coexistence is often invoked as a way to avoid apportioning blame for violence in the (recent) conflicts. This may involve denying the suffering of particular victims, or it may be a way of deflecting blame from oneself-for instance, by scapegoating nationalist "agitators" or "extremists" and deflecting blame from the general population who have, it is claimed, "always gotten along together." In order to avoid these conceptual problems, I find it useful to return to the origins of the concept of peaceful coexistence and its entry into the study of Ottoman and post-Ottoman societies.

The term "peaceful coexistence" first emerged in the context of the Cold War to refer to Soviet policy toward non-communist states and was a central part of Soviet propaganda that set up a contrast with the conflictual foreign policy of the capitalist West. Indeed, it is in the post-1920 period that coexistence acquires academic relevance as a term to explain how nations or groups may live side by side without conflict. "Peaceful coexistence," then, originally emerges as a diplomatic term that assumes hard boundaries around collective entities and calls for noninterference 
between those entities. It was effectively an international term, not one applied to domestic issues, and in that sense is about horizontal, rather than vertical, relations between different social orders. However, as one early discussion notes, what distinguishes "peaceful coexistence" from "peace" per se is not only that it is the coexistence of different social orders but also that an active and strong implementation of peaceful coexistence would imply "the strengthening of contacts in the interest of aims which can be mutually formulated and settled" (Kende 1968: 362-63).

In the twentieth-century literature on the Ottoman Empire and its successor states, a state-based literature that focuses on an Ottoman "model of tolerance" that allowed religious practice relatively unimpeded has opened up to encompass social histories of how groups in the empire "coexisted," or lived together in relatively non-conflictual ways for centuries. ${ }^{12}$ The main focus of this literature is the operation of the millet system, which divided Ottoman society by faith and gave considerable, although hierarchical, freedoms to Christians and Jews that allowed them to practice their religions, be judged in civil cases under their own laws, and be represented by their own religious leaders. A significant part of the literature on tolerance examines the ways and the extent the Ottomans tolerated other religious groups under their rule.

While in the nationalist literatures of many former Ottoman subjects-especially in Southeast Europe-the Ottoman period was one of oppression, it is clear that during the Ottomans' long reign there were various periods when non-Muslims enjoyed greater freedoms than religious minorities in Europe. Indeed, one Ottoman historian makes the claim that the generosity of freedoms granted to non-Muslims under the millet system eventually led to that system's downfall:

If the Ottomans had done what other occupiers elsewhere did and forced those living under their occupation to change their religion, they would never have experienced the minority problem that weakened them in the last century of the Ottoman Empire. Instead the Ottomans protected the rights of Greek Orthodox, Armenians, and Jews to live their own lives with little interaction with the Ottoman ruling class, under the guidance of their own religious leaders, with their own languages and customs, their own schools, courts, orphanages, hospitals, etc., as long as they paid the required taxes and maintained the security and order of the empire. (Shaw 1985: 1003) ) $^{13}$

The vast literature in English, Turkish, and various languages of the former empire that addresses the question of non-Muslims under Ottoman rule has been concerned with understanding what freedoms were 
realized in practice (e.g., Greene 2002; Jennings 1993); how the Ottomans perceived non-Muslims (e.g., Barkey 2005; Masters 2004); what tolerance meant for the operation and longevity of the empire (e.g., Barkey 2007); and how those freedoms may have expanded or contracted in different periods (e.g., Greene 2002; Baer 2011). Because of its focus on state practice, "coexistence" as a question emerges when one begins to ask how Ottoman doctrines and practices of tolerance affected the ways that individuals interacted in daily life, perhaps especially in remote parts of the empire and at times when the state was not palpably present. Moreover, in discussions of the dissolution of that coexistence, a not insignificant part of the literature has focused on the ways that the millet system laid the ground for the strong merging of ethnic and religious identity that we find in many of the Ottoman successor states (e.g., Grigoriadis 2012; Hirschon 2010; Masters 2004).

For the Ottoman context, then, studies of toleration have primarily focused on the structure of the empire and the operation of the millet system. Studies of coexistence, on the other hand, examine the person-to-person interactions enabled, shaped, and impeded by such understandings of difference and their legal and political implementation. Moreover, while "toleration" implies living with or tolerating beliefs or practices that one finds wrong or disagreeable for social, economic, or political reasons, historiographically "coexistence" implies a nonhierarchical form of everyday interaction that is adopted as a manner of living. Historiographically, the primary distinction between these emphases appears to be that while "toleration" assumes that difference is perceived negatively, "coexistence" attempts to interrogate understandings of difference and boundaries, including indifference to difference.

It is perhaps to be expected that while studies by anthropologists have focused primarily on coexistence and shared spaces, especially shared religious sites ${ }^{14}$ historians until recently have turned much of their attention to the question of toleration. While tolerance, in this literature, is primarily a strategy of empire, coexistence, as Ussama Makdisi recently commented, is "more difficult to gage, to describe, and to get at through the available sources than is the practice and politics of toleration, especially when the sources present history from the imperial center and from those at the pinnacle of power in this center" (Baer, Makdisi, and Shryock 2009: 929). While Marc Baer takes issue with "coexistence" as an appropriate term to describe what was, during the Ottoman period, a set of relationships determined by hierarchy, we may turn to Karen Barkey's important work on the longue durée of Ottoman toleration for observations on the connection between the vertical relationship of toleration and the horizontal relationship of coexistence: 
In the Ottoman Empire, because religious identity determined a person's legal and political status, boundaries and belonging were essential; ethnic and religious peace could be maintained by both respecting boundaries and allowing movement across them. (Barkey 2008: 118)

Although her focus is the contribution of toleration to the durability of the empire, and therefore concentrates on state-society relations, she notes that Ottoman understandings of difference had a systemic quality:

The Ottoman understanding-similar to the Roman conception-was that difference was tolerated because it had something to contribute. That is, difference added to the empire; it did not detract from it, and therefore, it was commended. Toleration had a systemic quality; maintaining peace and order was good for imperial life, and diversity contributed to imperial welfare. (Barkey 2008: 110-11)

Such an imperial understanding of difference, she argues, trickled down into the relationships of everyday life.

Similarly, Aron Rodrigue argues that "the static 'mosaic' view, which posits building blocks for Middle Eastern society, in which each group is defined and fixed permanently by its religion or ethnicity, is not particularly useful analytically" Rather,

one can reinterpret the mosaic notion more dynamically, not stressing "minority/majority" or "ruler/ruled," but instead emphasizing the recognition of "difference" and, in fact, the near lack of any political will to transform the "difference" into "sameness." This is not the same as pluralism. The "difference" each group was ascribed, or ascribed to itself in its self-representation, was not articulated on the basis of rights. Rather, nothing in the political system of the Ottoman Empire called for different groups to merge into one. The difference was a given and accepted as such. (Rodrigue 1996)

By most historical accounts, then, the Ottoman Empire was a political space in which difference was recognized and salient in daily life. The hardness of boundaries and the extent to which they mattered clearly differed between village and town, between center and periphery, and between different periods of Ottoman rule. Periods when the rules governing the dress and comportment of religious minorities were lax were often followed by periods when they were more strictly enforced (Barkey 2008: 110-11). Historians have shown that during certain periods zealous sultans instituted campaigns of conversion (Baer 2011), 
while in other periods some of their subjects may have infringed the boundaries of their religious community in order to provoke their own martyrdom (Mazower 2005: 159-70). While we can understand practices and infringements of the rules governing religious difference from court records, eyewitness reports, and the records of travelers, we still lack sufficient means to understand how those who lived at the time perceived these differences. This presents a challenge for those wishing to comprehend coexistence as an everyday practice, as well as for those who wish to think about the necessary social conditions for long-term coexistence.

\section{The "Neighbor's Right"}

One of the few lenses we have for understanding the texture of intercommunal relations is provided by an indigenous term for sociality-in-proximity. Throughout much of the former Ottoman space, coexistence is encapsulated under the name of "neighborliness," what in Turkey and the Balkans is known as komşuluk, a conventional form of everyday interaction that acknowledges the need to accommodate and negotiate difference in the interests of local solidarity (Bringa 1995; Baskar 2012; Valtchinova 2012) ${ }^{15}$ In reference to the concept as it is understood in Bulgaria, Galia Valtchinova comments that komşuluk

has become a cultural category embracing the complex of rules and implicit knowledge about how to live together, side by side, without losing one's religious identity... If this ensemble of conventional attitudes and forms of sociability was supposed to ensure peaceful cohabitation in everyday life, it also allowed a safe distance between them. Often regarded as a "traditional" guarantee of religious peace, the komşuluk works through informal codes that are not well adapted to the modern categories of identity, belonging, or citizenship. (2012: 77)

Certain chapters in this volume (especially Dietzel on Cypriot rural land ownership) demonstrate the circumstances under which such conceptions of neighborhood may be shaken or destroyed, although "neighborliness" remains a reference point for ideas of the moral community.

Komşuluk describes a form of everyday life that implies interaction and interdependency while bracketing the affective. One may not love one's neighbors, but one normally needs to get along with them. Even more than this, however, in the Ottoman period the mahalle or neighborhood was an administrative unit in which persons were made legally 
responsible for each other and for maintaining the peace. As Barkey notes above, maintaining peace and order, what the Ottomans called sulh (Tamdoğan 2008), was an imperial priority. Moreover, the extensive literature on the Ottoman mahalle shows us the legal means by which persons were made responsible for each other. Neighborhoods were jointly assessed for taxes, but they were also made jointly responsible for crimes. Harboring a criminal often resulted in collective punishment. But similarly, one relied on one's neighbors for statements of one's character, as in cases found in local courts where persons wrongly accused of crimes such as theft and prostitution were found innocent on the basis of statements of their good character made by their neighbors.

Indeed, from the early Ottoman period until its end, we find accounts of how neighbors acted as "guarantors" (kefil) of each other's character. ${ }^{16}$ This was only possible, however, through close attention to the behavior of others and care in one's own actions and comportment. Some historians have called this an "auto-control mechanism" (Özcan 2001; Özsoy 1998; Yllmaz 2013), and all conclude that records show the neighborhood as an important social and legal unit. "It would not be wrong," says one historian, "to define the neighborhood community as one that has become a unity sharing a common fate, and with common rights and responsibilities" (Özcan 2001). Fikret Yılmaz, for instance, uses court records from Edremit to argue that the neighborhood was one in which

apart from the civil neighbor relationship it was in fact a control mechanism and a chain of persons who were guarantors for each other and therefore responsible to a degree for each other's behavior, in other words even more than a civil neighborhood, it had become a relationship of official duty, or at least we see that this is how the state had set it up. (Yllmaz, Gürkan, and Gratien 2013; also Yılmaz 1999/2000)

In other words, there seems to be agreement that "peace [huzur] in the neighborhood was the principle thing. There was no discrimination between Muslims and non-Muslims in that regard" (Özsoy 1998).

Moreover, persons tended to be identified based on their neighborhoods, as in "Fatma from Baştepe Mahallesi," or "Ali from Beșpınar Mahallesi." In the period before surnames and identity documents, identity was determined through oral information and witness statements given by those who knew the person best, i.e., neighbors. When necessary, "People who know the person would be asked questions such as, 'Who knows Rabia, and how do they know her? Does she have her wits about her?' in other words, 'Is she someone honorable who won't bring harm to anyone, or isn't she?" (Tamdoğan-Abel 2002: 68). Such statements had 
the effect not only of making neighbors morally accountable but also morally responsible for each other. The neighborhood, in other words, appears to have been understood as a moral community from which one also derived one's identity.

In this sense, then, neighborliness becomes a moral imperative, and one that continued to be written about in the ethics manuals (ahlak kitaplarl) of the nineteenth century that were part of late Ottoman public culture and education. ${ }^{17}$ Indeed, these manuals often discuss what was known as the "neighbor's right" (komşu hakkl), a right to aid and respect. In the various hadiths concerning the neighbor, neighbors are usually seen as having a combination of basic "rights": the "neighbor's right," which includes non-Muslims; the "Muslim's right"; and the "kinship right." Some neighbors may have only the first of these, while others may have two or more. "What is interesting in the ethics manuals of the Ottoman period," notes one historian, "is their advice to tolerate the faults of neighbors" (Tamdoğan Abel 2002: 68). Advice includes cultivating the virtues of patience and speaking in public about the virtues of one's neighbors, not about their shortcomings. Moreover, "another facet of the discourse of neighborly relations in Ottoman ethics manuals is that they do not establish a religious separation: the neighbor 'even if he is an infidel is still a neighbor and has the neighbor's right"' (Ibid.).

While the language of the "neighbor's right" may have disappeared today, there are many indications that the moral imperative of neighborhood remains important in the post-Ottoman space. As one young Turkish Cypriot who had a dispute with his English neighbor over access to his property commented to me, "He made me go to court, and now he won't speak to me. But we're neighbors! If something happens, your neighbor's there for you. Neighbors may be more important than family." Anthropologist Cornelia Sorabji noted a similar sense of duty among Muslims in Sarajevo in the 1980s and remarks, "The call of komsiluk is not heard through a cost/benefit filter but as a duty with religious overtones, a duty that is sometimes pleasurable and profitable, sometimes painful and testing, but never a neutrally moral choice" (Sorabji 2008: 104). The sense of duty rather than affection comes to the fore in these interactions: "In komsilluk painful feelings are put aside in the interests of the religiously sanctioned residential community" (Ibid.: 106; see also Henig 2012).

What emerges clearly from these descriptions is a mutual constitution of person and place, where the social person emerges through the milieu of the neighborhood, while the character of the neighborhood appears through the constitution of its community. The capacity of neighborhoods collectively to ban individuals who would sully their reputation 
(Çetin 2014) or the care to counsel one's neighbors are instances of the ways in which neighborhood and personhood are mutually constituting.

At the same time, this mutual constitution of person and place occurs within the context of mahalles that often were monoreligious. While this was not uniformly the case, and in large cities there were many mixed neighborhoods, it was the tendency for a mahalle to emerge around a central religious structure-a mosque, church, or synagogue-and for the neighborhood to take its name from that structure (Açık 2014; Tamdoğan 2008). Moreover, religious leaders often played important roles in these neighborhoods apart from conducting religious services, such as representing their neighborhood communities before the state. This might include making complaints about insufficient water supply and roads on behalf of their parishioners or acting as agents for registering births, deaths, marriages, and divorces (Açık 2014; Hızlı N.D.; Kazıcı 1982). Imams also acted as tax collectors, assessing the ability of their constituents to pay (Behar 2003: 6). On the other hand, neighborhoods tended not to be divided by occupation or social class, and "in intramural Istanbul, large mansions of pashas and beys neighboring the shanty lodgings of beggars (se'ele) or of street-porters ... were quite a common occurrence" (Ibid.: 5). The mahalle, then, may be taken as a social unit that for the most part was not divided by class; was often, though not always, divided by religion; and where protection of the mahalle, its honor, and its reputation were of central importance.

Given the political importance ascribed to the sociality of komşuluk, it should not be surprising that it occupies a significant role in postOttoman nostalgia for lost pluralism. In that nostalgia, there is a tendency to blur scale, equating the existence of certain neighborhoods where persons of different religions lived side by side, sharing the responsibilities of the mahalle, with the "peaceful" existence of religious and ethnic minorities within the Empire. In other words, the "fact" that religious minorities existed in the Empire for the most part without persecution-in other words, under a regime of tolerance-seems to blend with narratives of mixed neighborhoods, making the claim that "we are all neighbors" applicable even to larger political entities.

In contrast to this blurring of scale, the relatively self-contained nature of the mahalle and the intertwining of personhood and place point us to another feature of living together that I wish to emphasize here: what I have earlier called "the labor of peace." To speak of labor is to emphasize agonism rather than antagonism, and accommodation rather than amity. It is to recognize that neighborliness is not only about living with the Other but is equally importantly about the ways that one becomes a person in the other's eyes. It is also to recognize that the intertwining 
of Other and Self entails a ritualized sociality and forms of exchange that simultaneously bind persons and families together and create their difference. In coming to that point, I will first discuss two other features of Ottoman social structure that are important for our considerations: what I will call here "multi-scalar sovereignty," and the performativity of neighborliness. While the former concerns the type of territoriality produced through the neighborhood, the latter concerns the production of self within the context of the neighborhood. As we will see, both facets are important for thinking about the dissolution of neighborhood relations and the possibilities for living together after violence.

\section{"To Be Master of One's Own Home"}

The common Turkish saying, kendi evinin efendisi olmak (to be master of one's own home) has resonances with the English saying, "a man's home is his castle." Both phrases imply the sovereignty of the home, because while komşuluk requires interdependence, it also requires respecting the "sovereignty" of the other by not making too much noise, not blocking their passage, not picking the fruit from their trees. In the English saying, the image of a castle invokes sovereignty in the form of a king, but the phrase is more commonly used to signal the separation of public and private, or the noninterference of the state in private life. This noninterference is invoked by the walls of the castle, within which each man is his own king.

Rather than stressing the castle with its implications of walls and boundaries, the Turkish saying emphasizes the sovereign as "master" or "lord." In Turkish, to be an efendi or master is not only to be in control but equally to be someone deserving of respect, a realized person. Indeed, the word efendi comes originally from the ancient Greek authentes, which has connotations of self-realization or agency. This is a selfrealization, though, that happens within the context of place-making, the context in which one is known and acquires the respect that makes one "master."

Moreover, in both cases the idea of "home" may be used metaphorically, to refer not only to a house, but also to a larger unit, especially the nation-state. Indeed, we often find that international relations compares relationships between countries to those of neighbors. States have "neighborhood policies," while the doctrine of noninterference resembles the advice above that neighbors avoid too much curiosity about the other's home. In writings on plural societies, "the neighbor" often comes to stand for the Other, the non-ruling ethnic or religious group sharing a 
political space (Zizek, Santner and Reinhard 2013). The tendency to use the neighbor as a scale-free abstraction (compare Candea 2012) reflects similar tendencies in the study of hospitality, where Candea argues that the analogization of hospitality in the home to that in the nation is "tying together into causal chains entities of radically different sizes (individuals, nations, doors, villages, etc.)" (Candea 2012: S35; see also Herzfeld 1987). ${ }^{18}$ By using "the neighbor" to stand for a country, an ethnic group, and at the same time the person next door, the focus is on ethics (especially Levinas and Derrida's response) while sidelining the problems of scalar sovereignty.

Indeed, hospitality is the practice in which the scales of sovereignty embedded in discourses of neighborliness both emerge and are blurred. Put simply, although one owes hospitality to one's neighbors, in actual practice the neighbor emerges as the one who does not need hospitality. This becomes clear in ethnographic examples where various scales of "neighborliness" are employed. For instance, when I conducted research in Cyprus between 2003 and 2005 on the opening of the border that divides the island, I spent about nine months living in a town in northern Cyprus that had a mixed Turkish-Greek population before 1963. After the division of the island in 1974 and the flight of Greek Cypriots to the island's south, Turkish Cypriots originally from the town who had fled in 1963 returned, later to be joined by displaced Turkish Cypriots from the island's southern region and a small number of persons resettled from rural Turkey. A decade or so after the division, foreigners of various stripes, though mostly from the U.K. and Germany, also began to settle in the town. I rented a small apartment in a larger house in a neighborhood of Turkish Cypriots who had been displaced from the island's south. Many of my neighbors were also relatives or came from neighboring villages in the south.

The neighbor who lived opposite our house was a woman around fifty years of age whose husband ran the neighborhood coffee shop. While Şengül sometimes helped him, she mostly baked at home and sold her pastries to local shops. As a result, she was one of two or three female neighbors who were always home. Moreover, during the times that they were at home, their doors were always open, as is common in villages throughout the Eastern Mediterranean and Southeast Europe, where the open door implies both that neighbors are welcome and also that one has nothing to hide (see Henig 2012). Neighbors would step in and out, call to each other, occasionally stop by for coffee. While technically the rules of hospitality remained in place, as for instance the practice of always offering something to drink or eat, in practice hospitality became a referential discourse, something to which one could gesture and 
at the same time flout. In other words, neighbors do not occupy the category of "guests," and they may joke together about the formalities of hospitality. Similarly, Catherine Allerton (2012) notes how in Mangarrai relatives and neighbors may jokingly "become guests" at formal events, taking their places as guests because the formalities of the occasion demand it but at the same time recognizing that their intimacy with the hosts makes "becoming guests" a performance. Conversely, in the Turkish context, the moment when one ceases to be a guest and becomes an intimate treated with a more relaxed hospitality may be marked by the comment, yabancı değilsin artık (you are not a stranger/foreigner anymore).

Guests, then, come in many shapes and sizes, some more intimate than others. Neighbors, however, are hardly ever seen as guests, and certainly not as "strangers." Moreover, the open door puts the norms and rules of hospitality in abeyance. The neighbor's home is porous, although it is not "one's own." This indiscernability of the open door is both a form of community and a way of shaping oneself in the neighbor's eyes: one has nothing to hide, and one displays this honorable openness. To close the door is to hide, to retreat into private life. Given the traditional significance of the neighbor's testimony in the Ottoman neighborhood, it should not be surprising that neighbors are the primary persons in whose eyes reputation is formed. We will return to this consideration in a moment.

In contrast to the intimate hospitality of the neighborhood stands the formal hospitality of the host-guest relationship. ${ }^{19}$ It is the host-guest relationship that appears to be what A.M. Hocart had in mind when he observed that the original form of sovereignty is a hospitality event (Hocart 1957; also Candea and Da Col 2012: S7). While all hospitality depends upon the home and its sovereignty, the host-guest relationship also harbors another element: the guest is expected eventually to leave. In the town where I conducted research after the border opening in $\mathrm{Cy}-$ prus this element of sovereignty became especially contested in that displaced Turkish Cypriots were living in formerly Greek Cypriot houses. With the opening, the owners of those houses returned to visit them, although in the absence of a political solution to the island's division were not able to reclaim them. As a result, those persons with original title deeds to the houses were put in the role of guests being served coffee and lemonade in houses that they claimed as their own. The ambiguity of ownership and the pain of past conflict, then, were mediated through the rituals of hospitality: as good hosts, my neighbors said, "Of course we served them coffee! I wouldn't behave badly to someone who's a guest in my home." And as good guests, the Greek Cypriot visitors eventually would leave. 
In these encounters, the threshold materializes sovereignty, the point at which a stranger knocks or calls out even when the door is open. The open door is for the neighborhood, allowing the sovereignty of home to blend with the sovereignty of the community and signaling the mutual interpenetration of person and place. The open door symbolically blurs the space between inside and outside, between the house and the street, enabling everyday forms of negotiated interaction. Not only does one have nothing to hide from one's neighbors, but those neighbors also cannot pass without greeting. Unlike hospitality, then, it is a practice of moral exchange and interdependency that entails the everyday diplomacy of pleasantries, greetings, and often the exchange of important information in the form of gossip. I saw this in the ways that displaced Greek Cypriots mourned for their lost homes, not as structures but as parts of networks and neighborhoods. ${ }^{20}$ In their descriptions of home, what stands out are the paths between houses, the closeness of relatives, and the openness to fields and to others.

Both neighborliness and hospitality, then, are defined by closeness and distance, by boundary-making that depends upon the threshold of the home. But whereas hospitality depends upon the strict definition of the threshold as boundary between "ours" and "theirs," neighborliness in practice has depended on a blurring of that boundary and on forms of everyday diplomacy. When I refer to "everyday diplomacy" I mean not simply the negotiation of common terms or interests. Rather, I refer to the diplomat as emissary, someone who enters the space of the Other and addresses that Other in a common language. Thinking of diplomacy in this way opens up the possibility also to understand what Constantinou calls the "transformative potential of diplomacy," in other words, "the experience of new or expanding space, opening up possibilities and promising alternative ways of relating to others" (Constantinou 2006: 352; see also Constantinou 1996). Diplomacy, then, involves according respect to the Other but also the potential for self-transformation.

Taking a term from the language of diplomacy, I propose to think of everyday coexistence in post-Ottoman spaces as a labor of peace that relies upon a constructive ambiguity of the boundaries of belonging. By "labor of peace" I have in mind the everyday management of both sociality and tension that is most clearly seen in the neighborhood as a social unit. Sociality is managed through forms of symbolic and material exchange, from exchanging labor in fields to attendance at weddings and funerals. In remembering their lives together, both Turkish and Greek Cypriots from the same time independently recalled the neighborhood system in which families would take turns making halloumi, a local cheese and staple of the Cypriot diet. 
The labor of peace, however, also depends on both managing conflict and maintaining tensions. The local management of conflict is well known as a subject from the anthropological literature on dispute resolution (e.g., Nader 1991; Roberts 1979/2013; Starr 1978) and should be understood as what the Ottomans referred to as maintaining sulh. In places such as Cyprus, traditions of local dispute management created conflicts with British colonial rulers, who wished to replace them with formal judiciary practices. ${ }^{21}$ As one such administrator observed, under the Ottoman system "it was enough that a man was known as an evil-doer to the people generally, and that there was reasonable cause to believe him guilty of certain offences." 22 At the time of the British arrival, then, the sociolegal practices of the mahalle appear to have been in full force, and the multitude of complaints by British police regarding informal dispute resolution practices indicates that they continued until well into the twentieth century.

Apart from the resolution of disputes, however, the labor of peace also entailed what I have referred to as maintaining tensions. In her discussion of everyday coexistence in Karachi, Laura Ring observes that it is in women's bearing of tension, rather than men's discharging of it, that peace is maintained. In Ring's rendering, this "ethic of suspense" linked

generalized reciprocity with the ability to bear in tension, or hold in suspense, contradictory principles of social organization (nation and ethnic group, hierarchy and equality).... [T] reating stranger-neighbors as kin depended not on sentiments of love and attachment but on the willingness and ability to bear the tension of contradictory categories of belonging.... Social, cultural, and intergroup tension is thus managed via the bodies and subjectivities of women. (Ring 2006: 179)

Ring's sensitive study focuses specifically on the ways that women's bodies bear tension because men's bodies are presumed to be violent, incapable of tension and subject to exploding under it.

I cannot engage here with Ring's analysis of the gendered nature of this practice, which is certainly not specific to her field location but may nevertheless not be universally applicable. My own research indicates that while women may disproportionately "bear tension" in this way, the management of contradiction and ambiguity is an intrinsic part of living together. I choose to refer to this process as "constructive ambiguity," a term taken from diplomacy, where it means the use of ambiguous language to deal with sensitive issues about which parties would otherwise remain irreconcilable. 
In diplomacy, constructive ambiguity is the practice of setting aside those issues that cause conflict and moving to those issues about which agreement can be reached. In doing so, the hope is that eventually a new state of affairs will allow the parties to overcome previously irreconcilable differences. This in effect allows each side to claim that it has not conceded the point while allowing negotiations to proceed beyond it. One summary of the strategy notes, "Ambiguities make sure that, on the one hand, the parties retain their own individual perceptions as to "how things should proceed' and that, on the other, one common language is adopted, which both parties may later equally use" (Pehar 2001: 170). Language, in this case, acts as a type of boundary defining the possibility or impossibility of negotiation.

I use the term for what it brings to understanding the everyday negotiation of what Ring calls "tension." "Constructive ambiguity" is a process by which we agree to see differently on a particular issue while not letting that disagreement stand in the way of peace. It is a process of allowing certain boundaries to remain in place while finding common ground where it is possible. It does not deny difference; in fact, it recognizes difference in its refusal to confront it. It does not efface difference but rather denies that difference must be an insurmountable obstacle to sociality and peace. Constructive ambiguity brackets difference, allowing us to retain it while continuing with the everyday process of living.

Just as neighborliness makes the threshold porous, so in everyday life we may recognize, but at the same time bracket, the everyday differences that define boundaries in order to make those boundaries permeable. This is usually done in the interest of some larger cause perceived to be more important-what Kende, in his definition of strong peaceful coexistence, described as "the strengthening of contacts in the interest of aims which can be mutually formulated and settled." That cause may be the need to work together in the fields or marketplace, or simply the belief that the Other, despite Otherness, still subscribes to the moral code of neighborliness that protects the peace of a village. My Turkish Cypriot neighbor commented that "neighbors may be more important than family." And while in a struggle over land access the young Turkish Cypriot was willing to suspend difference in the interest of a higher moral code, his English neighbor saw the fence between them as a legal boundary defining his rights rather than a moral threshold defining his responsibilities.

I have suggested that we may usefully see the coexistence expressed in komşuluk as a constructive ambiguity of the boundaries of belonging, and I have also suggested that seeing it in this way may allow us insight into the everyday diplomacy of coexistence without necessitating insight 
into the affective realm, which is difficult to document in retrospect. Where that coexistence begins to break down, or where it may be difficult to repair, is where such ambiguity is no longer encouraged or feasible. Moreover, it should not be surprising that this occurs with the rise of demands for nation-state sovereignty, as we see that it was precisely in the demands for freedom of ethnic and religious minorities within the Ottoman Empire, as well as the Ottoman attempts to claw back against the empire's disintegration, that the scale of nation-state sovereignty penetrates the sovereignty of the neighborhood. Village and street-names are "nationalized," while national and religious symbols come to dominate local landscapes. In his contribution to this volume, Robert Hayden describes the changes in what he calls "religioscapes" with the advent of nationalist demands. Such changes included the building or destruction of minarets, as well as the size of mosques and churches.

I suggest that the tendency to blend scale in discussions of home or neighborhood is also an indication of multi-scalar sovereignty-the sovereignty of the home, of the mahalle, of the church, all of which have their own sovereign thresholds. In the past, crossing into another neighborhood was not very different from crossing the threshold of a home and entailed scrutiny, as well as rituals of hospitality (see Çetin 2014; Tamdoğan-Abel 2002). Crossing the threshold of a church or mosque was to step into the sovereign realm of faith, something one usually would not do if one did not "belong." These embedded sovereignties were made possible when the state and realm were perceived to belong to a dynasty but not to a "people." Although the Ottoman Empire was a Muslim Sunni state, the state was not equivalent to territory but rather imposed upon it and thereby encompassing all that lived within it. As a result, multi-scalar sovereignties present us with ambiguities and incompleteness in a way that is materialized in the threshold but that disappears with the homogenization of space in the nation-state era. Commenting on the ambiguities inherent in what I have called here multi-scalar sovereignties, Shryock remarks,

the underlying problem is one of sovereignty over a space whose incompleteness, both as a physical and a sovereign space, must be perpetually managed in ways that encourage interaction with outsiders. Bad guests and hosts come in many dramatic forms, but even before they drop the millstone or sever the hand that greets them, they are first of all people who refuse to accept the proper role of host or guest. This refusal is most likely to occur when guest and host cannot agree on who controls the space of interaction, who is sovereign, who be- 
longs, and who owes or should offer respect.... Shifts in scale compound these disagreements and create new ones. (Shryock 2012: S30)

One such scalar shift is when the space of the neighborhood, with its own intimate sovereignty, is overlaid by the exclusive territorial claims of the nation-state-claims that are often also in conflict with others.

Using the contributions to this volume, I would like to think about what the labor of peace and the constructive ambiguity that it entails would mean in the Ottoman and post-Ottoman context. What is helpful about the term "constructive ambiguity" is that it makes reference to a form of everyday diplomacy, to a way of acknowledging both difference and a common set of moral concerns that have priority over that difference. It also allows us to think with more specificity about the conditions under which such ambiguity is no longer possible, and about what happens when it is lost. In addition, it may enable us to identify why it is so difficult to recover such forms of everyday diplomacy in post-conflict interaction.

\section{Everyday Diplomacy in the Post-Ottoman Space}

My attempt to clear away some conceptual brush by referring to coexistence as a labor of peace, and more specifically one supported by the constructive ambiguity of the boundaries of belonging, is also in consonance with other works that have similarly struggled with how to conceptualize the meaning and perception of boundaries in the Ottoman and post-Ottoman space. Exploring the porosity of boundaries at the local level, Doumanis argues that intercommunality, as he calls it, was produced in the quotidian negotiations of daily life:

Ottoman mixed communities did not meld into one organic unit. However ... where such distinct units lived cheek by jowl it was also essential that boundaries shifted whenever dictated by necessity and social norms, and in order to promote an atmosphere of civility and cordiality. (Doumanis 2012: 65)

The everyday creation of community in this way is confirmed for other cases, such as Anja Peleikis's study of Lebanon, where she argues,

shared local identity was not a given simply because of the fact that Christians and Muslims used to live in the same place. On the con- 
trary, social relations across confessional borders had to be confirmed, created and reproduced again and again through the diverse everyday practice of neighborhood relations, mutual assistance in agriculture, and attendance at religious rituals of the confessional "Other." (Peleikis 2006: 134)

Community, then, may not be assumed but must be constantly reaffirmed and reproduced, emphasizing the conscious effort or labor involved. Laura Ring, in her discussion of everyday coexistence in contemporary Karachi, described a similar process of insisting on difference while at the same time complicating it: "[ $\mathrm{t}]$ he repeated insertion of the particular-the insistent invocation of the complexity and ambiguity of social identity - was critical to the very possibility of 'sharing the shade' or ham sayagi, the Urdu term for 'neighborhood"' (2006: 4).

The performance of coexistence also often entailed ritualized and even exaggerated expressions of community solidarity, expressed retrospectively in nostalgia for having attended each other's weddings. Doumanis notes,

[b]ehaving 'as if' they were one community was fundamental to intercommunality. Being like a community without being a community promoted solidarity for the purposes of social order and security, while at the same time ensuring that the distinctions remained intact. The purpose of loving one's neighbour was to keep that neighbour firmly at bay. (2012: 78)

Here Doumanis appears to fall into the identitarian trap he has tried to avoid, by effectively saying that such everyday constructions of community are simulacra rather than essence. In Deniz Duru's chapter in this volume, we see how such self-conscious valuing of plurality may construct the sense of community as community and of place as place.

Moreover, if we return to my earlier invocations of neighborliness and thresholds, we can see how "social order and security" may constitute a higher moral order that calls for constructive ambiguity of boundaries. Leaving one's door open signals both that the home is one's own and also that its threshold is porous. It is also, as certain authors in this volume make clear, a site of performativity. Opening one's door is also a way of constructing oneself in the neighbor's eyes, of displaying that one has nothing to hide. Moreover, one of the most important aspects of hospitality is the rehashing of it afterwards-what one served, how the guest behaved, what this indicates. Hospitality, then, is not only an event but is simultaneously a discourse on an event. In this sense, the moral dis- 
course of hospitality also shapes the moral practice of its performance: to be a good host is to be one not primarily in the eyes of one's guest but in the eyes of one's own community. Similarly with neighborliness: while people such as my own Turkish Cypriot neighbor often perceive the interdependence of neighborliness as something born of necessity, not to help one's neighbor is also to risk the talk of other neighbors.

The argument that everyday coexistence may be as much about the rules of social life as it is about individual relationships-as much about morality as affection and as much about performance as essence-is also in consonance with Ashutosh Varshney's empirical study (2003) of cities in India where ethnic conflict has occurred, and his well-argued claim that intercommunal civil associations are more effective in controlling violence than are individual relationships. "If vibrant organizations serving the economic, cultural and social needs of the two communities exist," Varshney claims, "the support for communal peace not only tends to be strong but it can also be more solidly expressed" (Ibid.: 10). In cities, his study shows, formal networks are important for facilitating what informal networks and relationships may be able to achieve in villages: namely, spaces for negotiating common goods that in turn make what might otherwise be exclusive demands into inclusive ones.

The chapters in this volume suggest that living together is a labor of peace that entails an everyday diplomacy, requires the blurring but not the dissolution of boundaries, and includes the potential for selftransformation. Chapters discuss the simultaneous exclusiveness and inclusiveness of boundaries symbolized by the threshold; the performative aspect of everyday coexistence; and the forms of common civility necessary to enable diversity within the same space. Together, the chapters help us to understand the "constructive ambiguity" that pervades everyday interactions, as well as the moments when such ambiguity or "civil inattention" (Goffman 1971) may no longer be possible.

In her discussion of the Ermou marketplace of Nicosia in this volume, Anita Bakshi, referring to Georg Simmel's now classic observations regarding the stranger, remarks that persons from the other group were both near and remote, defined by difference. However, within the space of the marketplace it was possible also to complicate and blur such borders through the recognition of individuals in face-to-face interactions:

The shared realm provided by the Ermou streets allowed for the recognition of specific differences-the elements that begin to form the outlines of individuals, distinguishing them from the group as a whole. These outlines may remain hazy. They need not be deep friendships, and indeed they probably often were not, but they do help to create 
a public life in which the individual can operate comfortably.... This allowed for a particular habitus to emerge, one constituted by the repetitive nature of interactions and facilitated by the stable pattern of streets and intersections. (this volume, p. 120)

The city, with its separate Greek and Turkish neighborhoods, included sites of exclusion as well as nodes of integration. Indeed, it was the drawing of boundaries that made neighborliness across those boundaries possible.

Similarly, Irene Dietzel shows how the complex land use and land ownership patterns of Ottoman Cyprus encouraged the interdependence and solidarity of village life. As may be seen elsewhere in the Mediterranean, multiple ownership in land, including rights to water and trees, as well as the complexities of farming in a parched climate, lent themselves to forms of cooperation and solidarity that began to disappear with the "rationalization" of land rights under the British administration and the "modernization" of land use in the mid-twentieth century. However, Aris Anagnostopoulos also reminds us in his own chapter that our conceptualization of such coexistence is also predetermined by its end, emphasizing ethno-religious cooperation before later conflict while covering over other forms of exclusion (class, gender, age, etc.) that were present during such periods of "peaceful coexistence." Bakshi gives the example of women excluded from certain marketplace spaces, while Deniz Duru's chapter describing interreligious interaction in Burgazadası, Istanbul, reminds us that such cross-ethnic or cross-faith interactions may be based on their own class, ideological, or gendered exclusions.

Sossie Kasbarian's discussion of the Armenian community in Turkey today is one where individuals think "in terms of clearly defined spheres and the need to transgress and move from one to the other." (this volume, p. 223). However, Kasbarian emphasizes that these spheres are defined not only by religious, ethnic or other identities but also by different historical narratives that must be accommodated. "When contemplating coexistence," Kasbarian remarks, "the coexistence of different narratives is at least as essential as physical coexistence" (this volume, p. 222).

Robert Hayden argues in this volume and elsewhere that examples such as Kasbarian's show that "'peaceful coexistence' is not so much a condition that can be disrupted, as a manifestation of relations at times when the dominance of one group over another is so firmly established that it need not be imposed, and cannot be much countered" (this volume, p. 62). In other words, any "peaceful coexistence" with a dominated minority is only temporary and is bound to change when power rela- 
tions do. He shows this through the physical domination of the landscape during the Ottoman period and attempts to erase signs of that domination in Ottoman successor states.

Other chapters, however, suggest that what may be important is not the "reality" of coexistence but rather its performance, in other words, the ways in which a constructive ambiguity of the boundaries of belonging is (self-)consciously constructed. While Duru's chapter shows the way that residents of the Istanbul island of Burgaz self-consciously value and construct plurality as part of the island's identity, Deborah Starr highlights the performativity of coexistence through discussion of what she calls the "Levantine idiom" in Togo Mizrahi's Alexandria films. Produced at a moment when Egypt was experiencing a rise of a new Arab/Islamic nationalism that excluded, for instance, the large Jewish community of which Mizrahi was a member, Mizrahi's farces use cross-dressing, class-hopping, and hints of homosexuality to emphasize the performative and fluid nature of (Levantine) identity. The "Levantine aesthetics" of the films is one in which "the performance of identity is fluid and mutable, embracing vagueness and porousness of the boundaries of identity" (this volume, p. 136). However, Starr emphasizes that the inclusiveness of this Levantine aesthetic is not "natural" but is explicitly depicted as something performed, an inclusivity that is both self-consciously and repetitively created.

Azra Hromadžić, in her study of a mixed Mostar gymnasium, returns to performativity when she shows how language "purism" in a mixed space is performed by youth often confused by what counts as "their" national language. "Youth," notes Hromadžić,

are ... called to accept, appreciate, welcome and act out this "authentic" difference-the essence of cultural hermaneutics-in exchange for acceptance into the larger transborder nation and domovina's (homeland's) recognition. As a result, language performance acts as a social ethics and cultural technology for successes and failures of national and individual dreams. (this volume, p. 193)

As she demonstrates, however, this ideology of cultural purity is also mapped onto territory, thus creating the presumption of "incommensurability of mutually hostile, spatially segregated ethnicities which are treated as rooted, bounded, homogeneous, and mutually hostile" (this volume, p. 193).

Both Sylvaine Bulle and Glenn Bowman's chapters use Erving Goffman to think about contiguity-what Bulle calls "co-presence"-in contexts that are potentially conflictual. In the context of a divided Jerusa- 
lem, Bulle describes the ephemeral "temporary communities of confidence" that emerge even in and around a security wall. Pizza deliveries, marketplaces, and tramways all provide spaces for interactions that are characterized by what Goffman called "civil inattention," a form of public civility that allows heterogeneous public spaces to function. Temporary communities of confidence "are created within situations where people simply come together, and are not affirmations of belonging," Bulle notes (this volume, pp. 248-9).

Bowman discusses this as "giving ground," what Bulle refers to as a basic civility in urban space:

Viewed not from the perspective of an ideal model of coexistence but rather from its actual practice, we see that small acts of respect for the Other-the exercise or not of domination, of courtesy, of civilitymay be able to construct a livable space, creating a place for people, while at the same time helping to build a shared life. (Bulle this volume, p. 252)

However, as Bowman notes, such forms of ordinary civility are enabled by "spaces" but impeded by "places." In other words, civility is possible only when one community does not make an exclusive claim to a site.

Taken together, the papers in this volume provide new insight into the everyday practices of living together in contexts fraught with conflict histories that include discrimination, displacement, and division. Authors here stress the importance of boundaries that define forms of neighborliness and cooperation, and the everyday diplomacy that allows those boundaries to remain constructively ambiguous. They describe, as well, the quotidian performances of coexistence, which comply with standardized notions of the civil and the cosmopolitan. And they explore the political potential of contiguity and civility for creating spaces defined by robust forms of living together.

\section{Notes}

1. On the way that a discourse of coexistence occludes the manner that coexistence was destroyed in Turkey, see Mills (2011) and Onar (2009).

2. On "the riot" and the post-conflict everyday, see Das (2007); Jeganathan (1997); Mehta (2002); and Mehta and Chatterji (2001).

3. See, for instance, the discussion of such nostalgic visions in Doumanis 2012: 2-19.

4. For a debate that outlines many of the stakes, see Robert Hayden's 2002 Current Anthropology article, including responses (Hayden 2002), as well as articles in Bowman (2012) that respond to Hayden's thesis. 
5. See Glenn Bowman and Dionigi Albera on Robert Hayden's antagonistic tolerance thesis (Bowman 2012; Albera 2012).

6. See Robert Hayden on Stef Jansen and others, as well as replies (Hayden 2007).

7. On the "eventful-ness" of history, see Pandey (2006) and Lubkemann (2008).

8. Doumanis remarks, for instance, "Whereas Ottomans presupposed that cultural difference within society was a given, Westerners tended to proceed from a diametrically opposite position, seeing societal homogeneity as normative and the Babel-like conditions in the Near East as symptomatic of societal degeneration" (Doumanis 2012: 18).

9. On the problem of the "clash of civilization" literature as it relates to the study of multiculturalism, see Mills (2011); Barkey (2005); and Baer, Makdisi, and Shryock (2009).

10. On the problems of identity as a concept in the social sciences, see the important article by Brubaker and Cooper (2000).

11. In Cyprus, for instance, Greek Cypriot nationalists beginning in the 1950s advanced the thesis that Turkish Cypriots were really converted Orthodox and therefore Greek "by blood." Since 1974, the Republic of Cyprus has officially claimed that Cypriots lived "like brothers" before the 1974 Turkish invasion and division of the island. The Left, in turn, has supported "Cypriotism," the claim that Cypriots are "really all the same" and that they were divided by nationalist elements. While this thesis has gained support from left-wing Turkish Cypriots when it is future-oriented and refers to an inclusive, civic patriotism, Turkish Cypriots have tended to give it considerably less support when it is used to refer to "identity."

12. Classic texts that discuss Ottoman tolerance include those by Inalcik (1973), Lewis (1961), and Shaw (1976), as well as one more recently by Ortaylı (2003). For a collection that draws together works on both tolerance and coexistence in the Ottoman domains, see Karpat (2010).

13. This and all other translations from Turkish in the text are my own.

14. There is, indeed, a significant body of anthropological work on shared shrines that constitutes a large part of the ethnographic work on the sharing of space in Southeast Europe and the Middle East. For more on the subject, see recent works by Albera and Couroucli (2012); Barkan and Barkey (2015); Bigelow (2010); Bowman (2012a); and Hayden and Walker (2013).

15. In the Balkan context, the discussion of komšilik has centered primarily on the question of whether or not those relations were antagonistic in the context of the Balkan wars. The term, which comes from the Turkish komşuluk, not only means "neighborhood" rather than "neighborliness," but it also appears specifically to have acquired the meaning of living with plurality. Nevertheless, as I discuss below, the term appears to have retained in the Balkans some of the normative and affective dimensions of the more general "neighborliness," which applies to all forms of living in proximity.

16. For a discussion of the contested way in which this system was destroyed by British colonial rule in Cyprus, see chapter two in Bryant (2004). 
17. On ethics manuals in the late Ottoman period, particularly their use in education, see Fortna (2002).

18. Also, Andrew Shryock remarks, "Hospitality, as Bedouin describe it, is a quality of persons and households, of tribal and ethnic groups, and even of nation-states. At any of these levels of significance, failure to provide karam [hospitality] suggests low character and weakness, qualities that attract moral criticism" (Shryock 2012: S20).

19. Herzfeld has referred to the often aggressive hospitality of the region, as well as the suspension of hostility that contains the ever-present possibility of its degeneration, as "courtesy-as-menace." He remarks that these encounters have a "fragile, nervous force" that he suggests derives from their formality. "It is formality, not the simple act of giving, that creates the ambivalence and tension that is so prominent in the literature about Southern Europe, my own contributions included" (Herzfeld 2012: S214).

20. For more detail, see Bryant (2010).

21. I document this in a previous work (Bryant 2004), in which I devote a chapter to the transition from the Ottoman to the British legal systems. Complaints of the loss of authority by village elders are multitude, and British administrators received numerous letters vociferating against the centralized nature of the new system and the refusal to accept the word of village elders as binding to convict. In 1895, the Bishop of Kition, for instance, reported that "the people wish restrictions to be put on persons of bad character, on persons whom the Mukhtar [headman] and Ayas [Turkish $\underline{a \breve{g} a}=$ elder] of a village may say are of bad character. Such persons might be restricted by being confined to certain localities" (Parliamentary Papers, 1887-1895, quoted in Bryant 2004).

22. Parliamentary Papers, 1887-1895: 51.

\section{References}

Açık, Turan. 2014. “Mahalle ve Camii: Osmanlı İmparatorluğu'nda Mahalle Tipleri Hakkında Trabzon Üzerinden bir Değerlendirme" [Neighborhood and mosque: An assessment of neighborhood types in the Ottoman Empire based on Trabzon]. OTAM 35: 1-39.

Albera, Dionigi. 2008. “'Why Are You Mixing What Cannot Be Mixed?': Shared Devotions in the Monotheisms." History and Anthropology 19(1): 37-59.

__. 2012. "Combining Practices and Beliefs: Pilgrims at Marian Shrines." In Sharing the Sacra: The Politics and Pragmatics of Intercommunal Relations around Holy Places, ed. G. Bowman, 10-24. New York/Oxford: Berghahn Books.

Albera, Dionigi, and Maria Couroucli, eds. 2012. Sharing Sacred Spaces in the Mediterranean: Christians, Muslims, and Jews in Shrines and Sanctuaries. Bloomington: Indiana University Press.

Allerton, Catherine. 2012. “Making Guests, Making 'Liveliness': The Transformative Substances and Sounds of Manggarai Hospitality." Journal of the Royal Anthropological Institute (N.S.): S49-S62. 
Appadurai, Arjun. 1981. "Gastro-politics in Hindu South Asia." American Ethnologist: 494-511.

Argyrou, Vassos. 1996. Tradition and Modernity in the Mediterranean: The Wedding as Symbolic Struggle. Cambridge: Cambridge University Press.

Baer, Marc. 2011. Honored by the Glory of Islam: Conversion and Conquest in Ottoman Europe. New York: Oxford University Press.

Barkan, Elazar, and Karen Barkey. 2015. Choreographies of Shared Sacred Sites: Religion, Politics, and Conflict Resolution. New York: Columbia University Press.

Barkey, Karen. 2005. "Islam and Toleration: Studying the Ottoman Imperial Model." International Journal of Politics, Culture, and Society 19(1/2): 519.

- 2008. Empire of Difference: The Ottomans in Comparative Perspective. Cambridge: Cambridge University Press.

Baskar, Bojan. 2012. "Komšiluk and Taking Care of the Neighbor's Shrine in Bosnia-Herzegovina." In Sharing Sacred Spaces, ed. Albera and Couroucli, 51-68.

Behar, Cem. 2003. A Neighborhood in Ottoman Istanbul: Fruit Vendors and Civil Servants in the Kasap Ilyas Mahalle. New York: State University of New York Press.

Bigelow, Anna. 2010. Sharing the Sacred: Practicing Pluralism in Muslim North India. Oxford: Oxford University Press.

Bowman, Glenn. 1993. "Nationalizing the Sacred: Shrines and Shifting Identities in the Israeli-Occupied Territories." Man 28(3): 431-60.

- ed. 2012a. Sharing the Sacra: The Politics and Pragmatics of Intercommunal Relations around Holy Places. Oxford: Berghahn Books.

_ 2012b. "Introduction: Sharing the Sacra." In Sharing the Sacra, ed. Bowman, 1-9.

_. 2012c. "Identification and Identity Formations around Sacred Shrines in West Bank Palestine and Western Macedonia." In Sharing Sacred Spaces, ed. Albera and Couroucli, 10-28.

Braude, Benjamin, and Bernard Lewis, eds. 1982. Christians and Jews in the Ottoman Empire: The Functioning of a Plural Society, 2 vol. New York: Holmes \& Meier.

Bringa, Tone, Debbie Christie, and Granada Television. 1993. We Are All Neighbours. London: Granada Television Productions.

Brubaker, Rogers, and Frederick Cooper. 2000. "Beyond 'Identity'” Theory and Society 29: 1-47.

Bryant, Rebecca. 2004. Imagining the Modern: The Cultures of Nationalism in Cyprus. London: I. B. Tauris.

— 2010. The Past in Pieces: Belonging in the New Cyprus. Philadelphia: University of Pennsylvania Press.

Candea, Matei. 2012. "Derrida en Corse: Hospitality as Scale-Free Abstraction." Journal of the Royal Anthropological Institute (N.S.): S34-S48.

Candea, Matei, and Giovanni de Col. 2012. "The Return to Hospitality." Journal of the Royal Anthropological Institute 18 (N.S.): S1-S19. 
Çetin, Cemal. 2014. “Osmanlı Toplumunda Mahalleden İhraç Kararları ve Tatbiki: Konya Örneği (1645-1750)” [Neighborhood expulsion decisions and their implementation in Ottoman society: The Konya example (16451750)]. History Studies 6(6): 43-70.

Chau, Adam Yuet. 2008. “The Sensorial Production of the Social." Ethnos 73(4): 485-504.

Constantinou, Costas M. 1996. On the Way to Diplomacy. Minneapolis: University of Minnesota Press.

Constantinou, Costas M. and Yiannis Papadakis. 2001. "The Cypriot State(s) in situ: Cross-ethnic Contact and the Discourse of Recognition." Global Society 15(2): 125-48.

- 2006. "On Homo-Diplomacy." Space and Culture 9: 351-364.

Das, Veena. 2007. Life and Words: Violence and Descent into the Ordinary. Berkeley: University of California Press.

Doumanis, Nicholas. 2012. Before the Nation: Muslim-Christian Coexistence and its Destruction in Late-Ottoman Anatolia. Oxford: Oxford University Press.

Driessen, Hank. 2005. "Mediterranean Port Cities: Cosmopolitanism Reconsidered." History and Anthropology 16: 129-141.

Ergenç, Özer. 1984. “Osmanlı Şehrindeki 'Mahalle'nin İşlev ve Nitelikleri Üzerine" [The function and qualities of the "neighborhood" in the Ottoman city]. Osmanlı Araştırmaları 4: 69-78.

Fortna, Benjamin. 2002. Imperial Classroom: Islam, the State, and Education in the Late Ottoman Empire. Oxford: Oxford University Press.

Fuhrmann, Malte. 2003. "Cosmopolitan Imperialists and the Ottoman Port Cities: Conflicting Logics in the Urban Social Fabric." Cahiers de la Méditeranée 67.

Goffman, Erving. 1971. Relations in Public: Microstudies of the Public Order. New York: Basic Books.

Greene, Molly. 2002. A Shared World: Christians and Muslims in the Early Modern Mediterranean. Princeton: Princeton University Press.

Grigoriadis, Ioannis N. 2012. Instilling Religion in Greek and Turkish Nationalism: A "Sacred Synthesis." New York: Palgrave.

Hadjiprokopiou, Panos. 2012. "Haunted by the Past and the Ambivalences of the Present: Immigrations and Thessalonica's Second Path to Cosmopolitanism." In Post-Cosmopolitan Cities: Explorations of Urban Coexistence, ed. Caroline Humphrey and Vera Skvirskaja, 194-216. Oxford: Berghahn Books.

Halpern, Jodi, and Harvey M. Weinstein. 2004. "Rehumanizing the Other: Empathy and Reconciliation." Human Rights Quarterly 26(3): 561-583.

Hatay, Mete. 2011. "Coexistence or Domination? The Minaret and Belltower in Historical Perspective." Paper presented at the conference Shared Spaces and their Dissolution: Practices of Coexistence in Cyprus and Elsewhere, 14 October 2011, Nicosia, Cyprus.

Hayden, Robert. 2002. "Antagonistic Tolerance: Competitive Sharing of Religious Sites in South Asia and the Balkans." Current Anthropology 43(2): 205-31. 
— 2007. "Moral Vision and Impaired Insight: The Imagining of Other Peoples' Communities in Bosnia." Current Anthropology 48(1): 105-31.

Hayden, Robert M., and Timothy D. Walker. 2013. "Intersecting Religioscapes: A Comparative Approach to Trajectories of Change, Scale, and Competitive Sharing of Religious Spaces." Journal of the American Academy of Religion 81(2): 399-426.

Henig, David. 2012. “'Knocking on my Neighbour's door: On Metamorphoses of Sociality in Rural Bosnia." Critique of Anthropology 32(1): 3-19.

Herzfeld, Michael. 1987. “'As In Your Own House': Hospitality, Ethnography, and the Stereotype of Mediterranean Society." In Honor and Shame and the Unity of the Mediterranean, ed. D. Gilmore, 75-89. Washington, DC: American Anthropological Association.

—. 2012. "Afterword: Reciprocating the Hospitality of These Pages." Journal of the Royal Anthropological Institute (N.S.): S210-S217.

Hirschon, Renee. 2010. "Dismantling the Millet: Religion and National Identity in Contemporary Greece." In Nationalism in the Troubled Triangle: Cyprus, Greece and Turkey, ed. A. Aktar, N. Kızıyürek, and U. Özkırımlı. London: Palgrave.

Hızlı, Mefail. N.D. “Osmanlı Mahalle İmamlarının Performanslarına Dair” [Regarding the performances of Ottoman neighborhood Imams]. Tesam Akademi Dergisi: 41-51.

Hocart, A.M. 1952. "The Divinity of the Guest." In The Life-Giving Myth and Other Essays, 78-86. London: Methuen.

Humphrey, Caroline. 2012. "Hospitality and Tone: Holding Patterns for Strangeness in Rural Mongolia." Journal of the Royal Anthropological Institute (N.S.): S63-S75.

İhsanoğlu, Ekmeleddin. 2004. A Culture of Peaceful Coexistence: Early Islamic and Ottoman Turkish Examples. Istanbul: Research Centre for Islamic History.

Inalcık, Halil. 1973. The Ottoman Empire: The Classical Age 1300-1600. London: Weidenfield and Nicolson.

Jeganathan, Pradeep. 1997. "After a Riot: Anthropological Locations of Violence in an Urban Sri Lankan Community." Ph.D. dissertation, University of Chicago, Department of Anthropology.

Jennings, Ronald C. 1978. "Kadi, Court and Legal Procedure in the 17th century Ottoman Kayseri.” Studia Islamica 48: 133-72.

-1993. Christian and Muslims in Ottoman Cyprus and the Mediterranean World, 1571-1640. New York University Studies in Near Eastern Civilization XVIII. New York: University Press.

Karpat, Kemal H. 2010. The Ottoman Mosaic: Exploring Models for Peace by Re-Exploring the Past. Seattle, WA: Cune Press.

Kazıcı, Ziya. 1982. "Osmanlılarda Mahalle İmamlarının Bazı Görevleri” [Some duties of neighborhood Imams among the Ottomans]. Íslam Medeniyeti Mecmuası 5(3).

Kende, Istvan. 1968. "Peaceful Co-Existence: Its Interpretation and Misinterpretation." Journal of Peace Research 5(4): 352-64. 
Lafi, Nora. 2013. "Mediterranean Cosmopolitanism and its Contemporary Revivals: A Critical Approach." New Geographies 5: 325-33.

Lerner, Warren. 1964. "The Historical Origins of the Soviet Doctrine of Peaceful Coexistence." Law and Contemporary Problems 29: 865-70.

Leustean, Lucian N., ed. 2014. Orthodox Christianity and Nationalism in Nineteenth-Century Southeastern Europe. New York: Fordham University Press.

Lewis, Bernard. 1961. The Emergence of Modern Turkey. Oxford: Oxford University Press.

Lubkemann, Stephen C. 2008. Culture in Chaos: An Anthropology of the Social Condition in War. Chicago: University of Chicago Press.

Marsden, Magnus. 2012. "Fatal Embrace: Trading in Hospitality on the Frontiers of South and Central Asia." Journal of the Royal Anthropological Institute (N.S.): S117-S130.

Masters, Bruce. 2004. Christians and Jews in the Ottoman Arab World: The Roots of Sectarianism. Cambridge: Cambridge University Press.

Mazower, Mark. 2005. Salonica, City of Ghosts: Christians, Muslims and Jews 1430-1950. New York: Harper Perennial.

Mehta, Deepak. 2002. "Writing the Riot: Between the Historiography and Ethnography of Communal Violence in India." In History and the Present, ed. P. Chatterjee and A. Ghosh, 209-41. New Delhi: Permanent Black.

Mehta, Deepak, and Roma Chatterji. 2001. "Boundaries, Names, Alterities: A Case Study of a 'Communal Riot' in Dharavi, Bombay." In Remaking a World: Violence, Social Suffering, and Recovery, ed. V. Das, A. Kleinman, M. Lock, M. Ramphele, and P. Reynolds, 201-49. Berkeley: University of California Press.

Mills, Amy. 2008. "The Place of Locality for Identity in the Nation: Minority Narratives of Cosmopolitan Istanbul." International Journal of Middle East Studies 40(3): 383-401.

__ 2011. "The Ottoman Legacy: Urban Geographies, National Imaginaries, and Global Discourses of Tolerance." Comparative Studies of South Asia, Africa, and the Middle East 31(1): 183-95.

Mills, Amy, James A. Reilly, and Christine Philliou. 2011. "The Ottoman Empire from Present to Past: Memory and Ideology in Turkey and the Arab World." Comparative Studies of South Asia, Africa, and the Middle East 31(1): 133-36.

Nader, Laura. 1991. Harmony Ideology: Justice and Control in a Zapotec Mountain Village. Stanford, CA: Stanford University Press.

Onar, Nora Fisher. 2009. "Echoes of a Universalism Lost: Rival Representations of the Ottomans in Today's Turkey." Middle Eastern Studies 45(2): 229-41.

Ortaylı, İlber. 2002. "Osmanlı İmparatorluğu'nda Millet Sistemi” [The millet system in the Ottoman Empire]. Türkler X. Ankara: Yeni Türkiye Yayınları.

—. 2003. Osmanlı Barışı [The Ottoman peace]. Istanbul: Uçar Matbaası.

Özcan, Tahsin. 2001. "Osmanlı Mahallesi Sosyal Kontrol ve Kefalet Sistemi" [The social control and guarantee system of the Ottoman neighborhood]. Marife 1. 
Özsoy, Osman. 1998. “Osmanlı Toplumunda Mahalleliler Arası Münasebetler” [Relations between neighbors in Ottoman society]. Tarih Dergisi, December 1998: 59-62. http://www.osar.com/modules.php?name=News\&file=ar ticle\&sid $=240352$.

Pandey, Gyanendra. 2006. Routine Violence: Nations, Fragments, Histories. Stanford, CA: Stanford University Press.

Pasieka, Agnieszka. 2014. "Neighbors: About the Multiculturalization of the Polish Past." East European Politics and Societies and Cultures 28(1): 225-51.

Pehar, Dražen. 2001. "Use of Ambiguities in Peace Agreements." In Language and Diplomacy, ed. Jovan Kurbalija and Hannah Slavik, 163-200. Malta: DiploProjects.

Peleikis, Anja. 2006. "The Making and Unmaking of Memories: The Case of a Multi-Confessional Village in Lebanon." In Memory and Violence in the Middle East and North Africa, ed. U. Makdisi and P. A. Silverstein, p. 133150. Bloomington: Indiana University Press.

Philliou, Christine. 2008. "The Paradox of Perceptions: Interpreting the Ottoman Past through the National Present." Middle Eastern Studies 44: 661-75.

Ring, Laura. 2006. Zenana: Everyday Peace in a Karachi Apartment Building. Bloomington: Indiana University Press.

Roberts, Simon. 1979/2013. Order and Dispute: An Introduction to Legal Anthropology. New Orleans, LA: Quid Pro Books.

Rodrigue, Aron. 1996. "Difference and Tolerance in the Ottoman Empire: Interview by Nancy Reynolds." Stanford Electronic Humanities Review 5(1), special issue, "Contested Polities." http://web.stanford.edu/group/SHR/5-1/ text/rodrigue.html.

Sampson, Steven L. 2003. "From Reconciliation to Coexistence." Public Culture 15(1): 181-86.

Shaw, Stanford. 1976. History of the Ottoman Empire and Modern Turkey. Cambridge: Cambridge University Press.

— 1985. "Osmanlı İmparatorluğu'nda Azınlıklar" [Minorities in the Ottoman Empire]. Tanzimat'tan Cumhuriyet'e Türkiye Ansiklopedisi [Encyclopedia of Turkey from the Tanzimat to the Republic]. Istanbul: İletişim Yayınları.

Shryock, Andrew. 2004. "The New Jordanian Hospitality: House, Host, and Guest in the Culture of Public Display." Comparative Studies in Society and History 46: 35-62.

_ 2012. "Breaking Hospitality Apart: Bad Guests, Bad Hosts, and the Problem of Sovereignty." Journal of the Royal Anthropological Institute (N.S.): S20-S33.

Singh, Bhrigupati. 2011. "Agonistic Intimacy and Moral Aspiration in Popular Hinduism: A Study in the Political Theology of the Neighbor." American Ethnologist 38(3): 430-50.

Sorabji, Cornelia. 2008. "Bosnian Neighbourhoods Revisited: Tolerance, Commitment and Komsĭluk in Sarajevo." In On the Margins of Religion, ed. F. Pine and J. de Pina-Cabral, 97-114. Oxford: Berghahn Books. 
Starr, Deborah. 2005. "Recuperating Cosmopolitan Alexandria: Circulation of Narratives and Narratives of Circulation." Cities 22(3): 217-28.

Starr, June. 1978. Dispute and Settlement in Rural Turkey: An Ethnography of Law. Leiden: Brill.

Stefansson, Anders H. 2010. "Coffee after Cleansing? Co-existence, Co-operation, and Communication in Post-Conflict Bosnia and Herzgovina." Focaal-Journal of Global and Historical Anthropology 57: 62-76.

Stewart, Charles. 1999. "Syncretism and Its Synonyms: Reflections on Cultural Mixture." Diacritics 3: 40-62.

Suárez-Navaz, Liliana. 2004. Rebordering the Mediterranean: Boundaries and Citizenship in Southern Europe. Oxford: Berghahn Books.

Tamdoğan, Ișık. 2008. "Sulh and the 18th Century Ottoman Courts of Üsküdar and Adana." Islamic Law and Society 15: 55-83.

Tamdoğan-Abel, Işık. 2002. “Osmanlı Döneminden Günümüz Türkiye'sine 'Bizim mahalle"' ["Our neighborhood" from the Ottoman Period to present-day Turkey] İstanbul Dergisi 40: 66-70. http://www.os-ar.com/mod ules.php? name $=$ Encyclopedia\&op $=$ content $\&$ tid $=501674$.

Tanyeri-Erdemir, Tuğba, Robert M. Hayden and Aykan Erdemir. 2014. "The Iconostatis in the Republic Mosque: Transformed Religious Sites as Artifacts of Intersecting Religioscapes." International Journal of Middle East Studies 46(2): 489-512.

Varshney, Ashutosh. 2003. Ethnic Conflict and Civic Life: Hindus and Muslims in India. New Haven, CT: Yale University Press.

Yavuz, Hakan. 1998. "Turkish Identity and Foreign Policy in Flux: The Rise of Neo-Ottomanism." Critique: Critical Middle Eastern Studies 12(7): 19-41.

Yllmaz, Fikret. 1999/2000. "XVI. yüzyllda Osmanlı toplumunda mahremiyetin sinırlarına dair" [On the limits of privacy in nineteenth-century Ottoman society]. Toplum ve Bilim 83: 92-110.

Yllmaz, Fikret, Emrah Safa Gürkan, and Chris Gratien. 2013. "Osmanlı'da Mahremiyetin Sinırları" [Limits of privacy among the Ottomans]. Ottoman History Podcast, No. 129 (9 November 2013) http://www.ottomanhistory podcast.com/2013/11/private-public-sphere-ottoman-empire.html.

Yosmaoğlu, Ipek. 2014. Blood Ties: Religion, Violence, and the Politics of Nationhood in Ottoman Macedonia, 1878-1908. Ithaca, NY: Cornell University Press.

Zaim, Derviș. 2010. Gölgeler ve Suretler [Shadows and Faces]. Istanbul: Maraton Filmcilik.

Zarinebaf, Fariba. 2012. "Intercommunal Life in Istanbul During the Eighteenth Century." Review of Middle East Studies 46(1): 79-85.

Zizek, Slavoj, Eric L. Santner and Kenneth Reinhard. 2013. The Neighbor: Three Inquiries in Political Theory, with a new Preface. Chicago: University of Chicago Press. 


\section{Part I}

$$
\alpha \cdot 6
$$

Landscapes of Coexistence and Conflict 



\title{
Sharing Traditions of Land Use and Ownership
}

\author{
Considering the "Ground" for Coexistence and Conflict \\ in Pre-modern Cyprus
}

IRENE DIETZEL

\begin{abstract}
Crypr studies" abound, especially since the island's division in 1974 into a Turkish North and a Greek South, an event that formed a tragic closure to two decades of unrest and quarrels between the communities. Peaceful coexistence of Muslims and Christians in Cyprus has been largely attributed to the dynamics of "neighborhood" (Jennings 1993, 1999; Asmussen 2001; Bryant 2004). Mixed neighborhoods, urban as well as rural, emerged during the Ottoman period (1571-1878) as a result of heterogeneous residence patterns, which at first did not follow any systematic pattern of spatial segregation. ${ }^{1}$ By the end of the Ottoman period the majority of villages (346 according to the first official census) were ethnically mixed. Although the number of mixed villages dropped drastically during the course of the twentieth century, the experience of life in mixed settlements has come to form a central part of the collective consciousness of Cypriots. The research on these shared spaces describes the texture and quality of coexistence as determined by the face-to-face-society and the rhythm of agricultural seasons. Despite a low rate of intermarriage, Cypriots forged a variety of inter-communal relations: they entertained neighborhood relations, formed friendships and cooperated in agricultural production.

This chapter contributes to this panoptic of neighborhood through an examination of the particular relationships that emerged from local forms of land use and shared concepts of property. Property relationswhether forged through inheritance practices among kin or maintained
\end{abstract}


through agricultural cooperation among neighbors-were deeply woven into the fabric of neighborhood. Yet, unlike the clear-cut model of individual ownership common to contemporary Western societies, local property concepts in Ottoman Cyprus involved various degrees of ownership, rights of use, as well as an obligation for maintenance-an Ottoman distinction that in itself generated particular and highly sophisticated forms of neighborhood.

Coexistence was certainly not free of conflict. Consider the following example from the mid-twentieth century, describing a state of affairs that seemed to alienate the Cypriot modernizers of the time. The geographer and later state-appointed consolidation officer Demetrios Christodoulou writes in 1959:

Land in Cyprus is unenclosed and unfenced. This permits not only easy subdivision, but also leads to endless friction between farmer and shepherd since the latter can roam with his flocks over anybody's property; friction, constant and costly, often exists between owners of neighboring land. (Christodoulou 1959: 84)

It is thus important to keep conflict and societal unrest between groups well within the scope of analysis. Indeed, practices of land use gave ample reason for dispute: The "constant and costly friction" described above may well be an example of what Bryant describes as "everyday diplomacy," a constant negotiation of boundaries that distinguishes neighborliness from plain hospitality (this volume, p. 21). Yet it is worth asking why conflicts over land and resources did not tend to coincide with ethnic distinctions, mobilize on the grounds of religious identities, or reiterate religious differences. What were the underlying structures that allowed for the management of communally accessed resources as well as the distribution of property in the absence of clear-cut boundaries? Did ethnoreligious differences play a part in the distribution process?

This chapter casts neighborhood in socio-ecological terms and focuses on particular strategies of Cypriot ruralists pertaining to the island's key resources of land, forests, and water. Whether a cause for conflict or cooperation, the particular strategies are "sociogenic" (compare Lansing 1991: 128). They generate specific forms of sociality that in turn maintain the social relations necessary for the strategy to succeed. These social relations can extend far beyond the bounds of the immediate neighborhood, yet property remains a key factor. The Ottoman system of land tenure provided the island's peasantry, both Christian and Muslim alike, with a context in which they could acquire, share, and maintain their access to land and resources. Furthermore, property was also defined 
by the particulars of the Mediterranean landscape. The socio-ecological perspective on Cypriot neighborhoods therefore also reflects the wider picture of the Mediterranean equation of landscape and people.

Local forms of daily coexistence did not cease with the end of Ottoman rule but survived well into the twentieth century. Nonetheless, the first half of the twentieth century witnessed a gradual dissolution of rural communities and traditional agricultural networks. ${ }^{2}$ These developments unfold prior to and along with the rise and consolidation of opposing Greek and Turkish national ideologies, the anti-colonial struggles of Greek nationalists (1955-59), as well as the violent clashes between the communities during the early years of the Republic (1963-64). The time of British colonial rule (1878-1960) therefore represents a transitional period during which the foundations for Ottoman coexistence gradually eroded. The study of coexistence in Cyprus thus inadvertently formulates a critique of colonial hegemonic practices. While the British "divide and rule" strategy has been the focus of numerous valuable studies (Constantinou 2007; Dietzel and Makrides 2009), this chapter also addresses less overt, and possibly less intentional disruptions of Ottoman coexistence, namely the British involvement in the modernization of the agricultural sector and the consequences this bore for societal dynamics between the island's communities.

\section{Reflections on the Ottoman System of Land Tenure}

Despite the official status of most arable land as property of the state, the Ottoman Mediterranean has been described as a "sea of land proprietors," where state land had de jure, rather than de facto character (Hadjikyriacou 2011: 49). However, the Ottoman ways of administering land and property were inherently different from those of Europe. An obvious difference lies in the absence of feudal structures in the Ottoman realm and the concomitant lack of a propertied hereditary noble class that could impose servile obligations on the peasantry. Rather, it was the "signature" of the Ottoman Empire that state control drew its legitimacy of rule from its paternalist protection of the autonomy of the peasant population. It was the priority and ideal of the central state to act as guarantor for the independence of the peasantry and the peasants' means of subsistence, to ensure the provision of the regional markets with agricultural goods, and to prohibit the excessive accumulation of land and resources by private individuals (İslamoğlu-İnan 1991: 58).

The empire administered land and resources in a "distributive-accommodative state environment" that was inclusive of local forms of 
land management and that ensured the loyalty of local authorities in the provinces through the distribution of state land and tax revenues (İslamoğlu 2004: 292). The Ottoman timar state economy depended on a particular system of land distribution, whereby the state leased land to tenants for cultivation, who in turn were expected to pay a portion of their revenue as taxes. The beneficiaries of these taxes were various local rulers or pre-Ottoman ruling groups, such as the Orthodox Church, yet they exercised no jurisdiction over the peasant producers. Jurisdiction over the peasantry lay with the $k a d l,{ }^{3}$ who represented Sultanic law (örf) and Sharia. The central state thus remained the sole source of legitimation for revenue collection (İslamoğlu-İnan 1991: 59).

The Ottoman agrarian landscape was thus fashioned by the cultivation patterns of small producers. Even under increased pressures of commercial expansion following the integration of the Ottoman realm into the world market during the seventeenth century, this pattern did not change in any significant way. While market pressures would encourage the formation of large-scale commercial agriculture and single-crop plantations elsewhere in Europe, small-scale production patterns remained predominant throughout the Ottoman realm (Keyder 1990).

In Cyprus, the Ottoman conquest of 1571 brought a change to the living conditions of the local peasantry that was akin to a socio-economic revolution. By granting the peasants-hitherto serfs on the plantations of Latin feudal lords-the right to resettle and bequeath their leases on state land to their children, Ottoman rulers encouraged the emergence of subsistence agriculture as the predominant form of land use. Another important shift affected the social stratification on the island. The complex social stratification that had characterized the Latin period was replaced by a basic division of society into two major classes: a ruling class (askeri) consisting of imperial administrators, nobility, military officials, and religious clergy, and a large, tax-paying peasant class (reayah).

The emergence of a large and religiously heterogeneous peasant class, as well as the autonomy of small-scale cultivators were important factors in the development of local forms of coexistence. Until the mid-nineteenth century, taxes and tithes were exacted from the villages as a whole-this, one might argue, necessitated a certain degree of internal village solidarity and thereby discouraged social or interethnic strife that could compromise the ability to meet tax requirements. ${ }^{4}$

The legal context of Ottoman land administration offered another flexible system that could accommodate a multitude of claims. Questions pertaining to the way in which the formal category of state property (miri) blended with existing patterns of land ownership have been little explored. The legal context that emerged, however, represents the 
ability of the empire to respond to the cultural diversity throughout its provinces. The Ottoman Land Code reflects the complexity of the system: promulgated by Sultan Abdul Mecid in 1858 during the Ottoman reform period, the Land Code aimed at modernizing the system of land tenure, but accommodated much of the old system within it. It set down no less than five types of categorization of land: ${ }^{5}$ the large part of arable land was state property (miri) that could be rented to individuals for cultivation. The tenant would have to hold a title deed to prove his, or her, ${ }^{6}$ rights to cultivate a particular plot. The tenant could also bequeath the lease to his, or her, children. The land could revert back into exclusive state ownership if the tenant left it uncultivated over a period longer than three years. In the case of reversion, the tenant could still buy the rights back by payment of an equivalent sum. This provision, however, was rarely enforced.

A second category comprised all immovables that were full property, or freehold (mülk). Next to land and houses, also planted trees, such as orchards and vineyards, as well as water holdings would fall under this category. In the latter cases, the law envisioned a system of "multiple ownership." A piece of land, for example, could be owned by the state and leased to a peasant, while the trees growing on this land, or the water that irrigated it could be owned by another.

The full property of religious organizations, however, was not subject to the Ottoman Land Code, but rather to Sharia law. While religious institutions were exempt from taxes, the revenue of these lands and properties, subsumed under the term evkaf, would be dedicated to religious and charitable purposes. The category of evkaf also included state-owned land, on which the tenant paid taxes and tithes to a religious organization and not to the state.

This communal purpose further defined all land that was dedicated to the public (metruk), such as those tracts in the vicinity of settlements, which were assigned to the inhabitants of villages or towns as a whole. These lands could not be individually possessed, bought, sold, inherited, or used for any other purpose other than that for which they were distinctly assigned ab antiquo. The category comprised communal forests, village pasture lands, public roads, and places of worship.

Finally, the remaining waste or rough-land (hali) could function as state land, while permission had to be granted for its use. All rights to utilization were revoked after three years of non-cultivation.

All of the above categories were important factors in the administration of Ottoman provinces. For the fabric of neighborhood, however, the particular stipulation for forms of multiple ownership may have been especially significant, since it legally bound together several individu- 
als as shareholders of one agricultural unit (such as irrigated orchards and multi-use fields). This kind of shareholding not only necessitated a certain level of cooperation, it also fused together the interests of shareholders in the functionality of the agricultural unit, thereby furthering a "sense of the commons"7 within the villages. To the quality of Ottoman neighborhoods, the system of land tenure added another realm of negotiation and diplomacy-perhaps analogously to the "constructive ambiguity of belonging" in Ottoman neighborhoods (this volume, p. 21ff), the Ottoman Land Code and its multiple forms of property reflect an equally constructive ambiguity of ownership.

\section{Reflections on the Mediterranean Landscape of Production}

While anthropologists have questioned the idea that an area with as much linguistic and religious diversity as the Mediterranean may represent a cultural unit (especially Herzfeld 1984; Pina-Cabral 1989), there seems to be more agreement on the Braudelian view of the Mediterranean as an ecological unit. Central works have identified the Mediterranean landscape as the fundament for a cultural distinction that nonetheless characterizes local traditions across the region (Braudel 1972; Horden and Purcell 2000; Tabak 2008). While all of these works acknowledge the landscape as a Mediterranean characteristic of longue durée, they vary in their estimation of the geo-deterministic element in Mediterranean history. Still, the history of Mediterranean localities, and with it Cypriot neighborhood, proceeds from the environmental strategies of local agriculturalists and pastoralists who have altered the Mediterranean landscape in a lasting fashion, rendering it essentially anthropogenic. Such reciprocity of environmental and human history is reflected in Horden and Purcell's concept of "micro-region." It includes "obvious microtopographical identifiers," such as the location of valleys, plains, or the sides of islands, characterized by their particular hydrology, soil conditions, vegetation cover, and annual weather cycle. But it also encompasses the various human effects on the landscape, such as the intensity of labor, the number of animals, and the specific choices of productive strategies. Micro-regions are further determined by the locations they are functionally connected to, such as harbors or detached pastures (Horden and Purcell 2000: 302). Traditional agriculture in Cyprus revolved around these micro-regions and the multitude of micro-economic opportunities they afforded. It is therefore important to imagine Cypriot rural neighborhoods and the "labor of peace" they 
entailed as taking place within these micro-regions, rather than as confined to the residential settlements of the village.

The landscapes of production in Ottoman Cyprus resembled the "agro-sylvo-pastoral system" typical for the Mediterranean region (Blondel 2010; Schnabel 2004; Delipetrou et al. 2008; Tabak 2008). The combination of cereals, tree-crops, and small livestock that made up the core of Cypriot small-scale production bore significant socio-ecological advantages, as it helped to optimize the use of microclimatic and edaphic variations on the island. Interestingly, this polycultural strategy was shared by all peasants, irrespective of their ethno-communal affiliations. In contrast to other cases of similar mosaic co-residence of ethnic communities, the Cypriot peasantry did not develop "niche-specific" agricultural practices (compare Barth 1956). Rather, both Muslim and Christian peasants used the environment in a similar fashion, while there was very little agricultural specialization in terms of ethno-typical preferences for either pastoralism or sedentary cultivation. Most households tended to exploit the full array of possibilities that polyculture could offer. In the semi-arid environment of the island these polycultural strategies as well as the agricultural mobility of Cypriots offered efficient ways to maximize the material basis for life even during periods of scarcity (Given 2000; Harris 2004). In terms of land use and ownership, polycultural strategies, and with it the experience of neighborhood, were fashioned by the basic features of land fragmentation, shifting cultivation, and a complex system of irrigation.

The phenomenon of land fragmentation has been a characteristic pattern of land use throughout Europe, especially in the Mediterranean. It is a result of local patterns of property distribution through inheritance systems, which in turn are subject to change according to demographic developments. While in many parts of Europe land fragmentation has been minimized through consolidation measures, it continues to be the central feature of the rural landscape in Cyprus. Typically, land fragmentation is seen as a problematic historic relic that is incompatible with modern means of agriculture and efficient production. While agrarian reformers of the mid-twentieth century lament the slow and insufficient implementation of consolidation measures (Shaw 1963; Lanitis 1992 [1944]; Christodoulou 1959), they misread or disregard the social and ecological dimensions of land fragmentation. More recent work suggests that under Mediterranean island conditions, land fragmentation holds significant advantages for the local population, by managing the risk of harvest loss, water shortages or pests (Bentley 1987). In sociogenic terms, the dispersal of land holdings is conducive to a very partic- 
ular form of agricultural cooperation that establishes a property relation beyond the level of the village neighborhood. Land fragmentation also engenders what Horden and Purcell call "structural absenteeism," a system that allows the cultivation of scattered fields with the help of other labor-providers who live closer to the particular piece of land (2000:280). Sharecropping thus alleviates the problems arising from the geographical separation of holdings, forges micro-economic relations across remote villages and maintains the connection between dispersed micro-regions.

Fragmented holdings are thus more suited to a system of "shifting cultivation," which is also known as "swidden" or "slash-and-burn-agriculture" (Horden and Purcell 2000: 264; Dove and Carpenter 2008: 26). ${ }^{8}$ Until the nineteenth century, the method of clearing vegetation within a cycle of cultivation was an integral part of local practices in Cyprus, especially for vine plantations. It also incorporated the grazing of goats as part of the land-use cycle and thus occasioned the cooperation of shepherds and farmers of one region. The strategy requires a profound knowledge of soil types and the ability to predict soil quality from vegetation cover. As Christodoulou notes for the Cypriot peasant, it was a highly empirical knowledge that was "inherited together with the land" (1959:41); one might add that developing such expertise must have been a central subject of daily communication among neighbors.

Finally, strategies of irrigation require the highest amount of coordination and negotiation. In Ottoman Cyprus, the use of surface water for irrigation was predominant and depended on a complex system of regulation. In mountainous regions, especially on the southern slopes of the Troodos Mountains, water had to be used effectively to avoid water run-off to the sea. This was envisaged through an intricate distribution of rights to irrigation, i.e., shares or holdings, which could be subdivided according to the needs of the local population. ${ }^{9}$ Land and water sources were held separately and were subject to the stipulations of multiple ownership. Interestingly, rather than providing top-down regulations through a central irrigation scheme, the Ottoman government accommodated traditional systems of distribution that had proved successful over time, and formalized them as part of the legal system. This was set down in Article 6 of Ottoman Civil Law: "Ab antiquo is left in its $a b$ antiquo state" (Christodoulou 1959: 90). Consequently, local ways of water management depended on constant negotiations among the many participants of local agricultural networks. The provision of the Ottoman government to give priority to long-established arrangements required the participants to give testimony based on memory, which resulted in frequent disputes (Ibid.). However, the use of water resources also formed a very practical focus of alliances across ethno-religious borders. 
Frequently, the inhabitants of villages or entire regions took joint action to ensure the water routing in their favor. One example comes from the mixed village of Kolossi, whose inhabitants in 1900 took joint action against a Greek Cypriot outsider who attempted to own all water rights in the region, in order to lease them back to the peasants. Local farmers forged such ad hoc alliances not only within villages, but also regionally. Such was the case in the villages of Styllos, Limnia, and Gaidhouras, all of which competed over water with the village of Prastio, leading the Muslim and Christian villagers to sign a joint petition against the water routing (Asmussen 2001: 138). These are just two out of numerous examples of water negotiations in which the ethno-religious identities of the quarrelling parties were rarely of any significance.

\section{Colonial Land Reforms and the Commodification of Property (1946-1974)}

So far, the modernization of land use has received only cursory attention in the study of the Cyprus conflict (Scott 1998; Heinritz 1975). Rarely is the abandonment of traditional land use patterns understood as a loss. On the contrary, the modernization of the agricultural sector is overwhelmingly seen as an advantage for society, as it guarantees the food security of a growing population and ensures the competitiveness of the agricultural sector through rationalization and an increase in profitability. However, the social and cultural consequences that accompany these transformations are often underestimated in their complexity.

The Ottoman Land Code continued to be in effect until it was finally abolished during the Land Reform of 1946. Depending on national perspective, the persistence of the Ottoman system under British rule has received different evaluation. The Turkish Cypriot perspective emphasizes the idea of its efficacy and sophistication as reasons for its continuation. To the modernizing minds of urban Greek Cypriots, however, both the Ottoman Land Code and the prevalent system of inheritance were considered backward, inappropriate, and in dire need of reform. As Christodoulou puts it: "Ownership in Cyprus is diffuse, fragmented and complicated. It militates against smooth transactions and rational economic land use" (1959: 85).

It was this "rational economic land use" that formed the main purpose of the land reforms of 1946. The Immovable Property Law of 1946 reformed tenure, registration, and valuation of land. It simplified the complex Ottoman Land Code by subsuming the diverse types of land under the two categories of "state land" and "private property." It also 
made provisions that targeted the abolition of the system of multiple ownership. Buildings and trees on a piece of land, as well as the land itself represented one agricultural unit, and as such were now to be the property of one and the same owner. The bill also aimed at limiting further fragmentation of land holdings, prescribing one dönüm ${ }^{10}$ for arable land and one dönüm for vineyard, orchard, or irrigated land as the smallest acceptable size (Lanitis 1992: 4). In addition, the land reform foresaw the consolidation of land holdings, in part as a necessary measure for the construction of water dams.

The consolidation law, which went into planning in 1956, met with repeated and fierce opposition from landowners, and only passed in 1969 (Heinritz 1975: 33). From the reformers' perspective, the peasants' opposition to agricultural reforms was nothing more than tedious parochialism. "Government has failed to realize that the peasant-farmer is by nature, as suspicious, obstinate and unprogressive as any human being can be. The whole world to him is his land, his home and the village coffee-shop. He would never go to the nearest town or even write to obtain advice. In fact, he would often treat any friendly suggestion as to the crops he grows or the way he cultivates his land as one made against his proper interests" (Lanitis 1992 [1944]: 70). Yet, acts of opposition against land reforms also contained an ethno-political dimension. According to the Turkish Cypriot Minister of Defense, the land consolidation measures of the early 1960s constituted a kind of Greek "land-grabbing exercise" that violated the constitution (Örek 1971).

The agricultural reforms mark an important shift from traditional land use patterns to modern ones. Certainly, local patterns of land use were slow to change. The reforms not only met with repeated opposition of farmers but were also compromised by the inevitable inertia of a well-established system. However, legal foundations were laid down with the new law, while former practices of land use were marginalized as backward impediments to progress and prosperity. In ecological terms, the land reform entailed the discontinuation and eventual loss of environmental practices that were well-adapted to the Mediterranean environment of the island. The commodification of land and the institutionalization of individual property as the sole form of ownership, which was to change property relations and social dynamics within Cypriot society, permitted the rise of a dynamic real estate market. Clothed in the guise of modernization, the land reform of 1946 thus literally removed the "ground" for trans-societal environmental cooperation, and should be included as a key date in the chronology of the Cyprus conflict.

The first part of the twentieth century sees a gradual transformation of the traditional rural economy of Cyprus, furthered along by the 
processes of urbanization and emigration. By the mid-century, most landowners no longer depended on agriculture as their sole source of income. According to the census of 1960, only about 50 percent of the privately owned arable land was being cultivated by the owner, while about 40 percent of agricultural land belonged to "non-farmers" (Heinritz 1975: 34). As a result, the system of management farming established itself as the dominant form of agricultural work, replacing other models of communal work, such as shareholding or cooperative farming (Heinritz 1975: 63).

In addition to this decoupling of land ownership from agricultural labor, the value of land was now determined within the context of a thriving real estate market. The prices for the different types of land were subject to high regional variability and reflected the priorities of urbanization and of newly emergent industries, above all the tourism sector. ${ }^{11}$ Most lucrative were those pieces of land that were suitable for construction, such as the dry land in the plains of the urban outskirts of Nicosia, but also the coastal areas, which due to their sandy soil and salty ground water had not been useful for cultivation.

Despite the decline of the actively farming population, agricultural productivity increased steadily. This was mainly achieved on perennially irrigated fields (such as citrus plantations), which yielded more produce in comparison to dry farming in areas that depended on seasonal rainfall. The proliferation of this form of intensive agriculture was furthered by government-subsidized construction of the water infrastructure necessary for the transformation of dry land into irrigated land. The increasingly invasive ways of tapping ground water created an unsustainable industry that further contributed to the severe water shortages on the island (Heinritz 1975: 200). This problem was also exacerbated through market speculations. In many cases, the owner who had installed the infrastructure for irrigation on a piece of land did not intend to use it for agricultural purposes, but rather planned to resell it for a higher price. This form of "upgrading" dry land was conducted without regard for groundwater limitations, putting the entire form of irrigated farming at risk (Ibid.: 78).

The advances in agriculture and the profits of the real estate market did not benefit the farming population, but rather those who did not depend on agricultural income. "Non-farmers"-urban Cypriots (doctors, lawyers or government officials), British customers, or Cypriots living in Britain - were thus at ease to buy land solely to use it as asset for market speculation (Heinritz 1975: 92). ${ }^{12}$

The real estate market not only catalyzed the emergence of a new land-holding class; it also provided another setting in which the Cyprus 
conflict unfolded, not least because it provided the possibility to accumulate the financial resources necessary for political campaigns. Between 1950 and 1970, the Orthodox Church sold large portions of its real estate, in part to further the activities of EOKA, the Greek national paramilitary organization that fought against British colonial rule and for the union of Cyprus with Greece (Enosis). The Orthodox Church also retained substantial assets, especially those in the non-agrarian sector (Heinritz 1975: 86). Moreover, it was within the context of the land market in which the inequalities between the ethnic groups were first manifest and where discrimination against the Turkish Cypriot minority took material form.

This is exemplified in the land transactions following the first violent clashes between the communities. In the course of the intercommunal fighting of 1963-64, a large part of the Turkish Cypriot population emigrated to enclaves under Turkish Cypriot administration. The relocation mainly affected Turkish Cypriots from mixed villages, as well as from smaller Turkish villages that were surrounded by predominantly Greek settlements. According to Turkish Cypriot sources, approximately 20,000 people (about 20 percent of the entire community) left their homes in order to move to the enclaves. ${ }^{13}$ Only a quarter of the total number of refugees returned to their homes in the following years. By 1970 about 15,000 members of the Turkish Cypriot community remained displaced (Heinritz 1975: 89). ${ }^{14}$

Maintaining a normal life and economy within the various enclaves that lay scattered over the island constituted a very complicated logistical act (Brey and Heinritz 1988). Given the mixed settlement patterns and the extension of traditional agricultural networks, Turkish Cypriots' land holdings, too, were dispersed and fragmented. Enclave conditions now made it difficult to cultivate or even access those Turkish Cypriot properties that were located too far from the enclave. Some of these holdings remained deserted, while others were used by Greek Cypriots who could be persuaded to pay a lease on them. The threat of planned and systematic acquisitions of Turkish Cypriot land by Greek Cypriots prompted the Turkish Cypriot leadership to issue a ruling that restricted all sales to intra-communal deeds or, if inter-communal, to exchanges with Greek Cypriot property of equal value. However, this ruling was often circumvented by exchanging the land in question with Greek Cypriot property of lesser value, while the difference was paid out covertly (Heinritz 1975: 90).

In retrospect, the shared spaces of Ottoman Cyprus appear a far-removed reality. Certainly, ethnic boundaries did not dissolve within the peasant context, yet they often remained secondary in the face of a common peasant lifestyle that was based on shared agricultural practices 
and environmental strategies. The relative lack of social stratification in Ottoman society, the mosaic co-residence of Christians and Muslims as well the predominance of cooperative strategies of polyculture facilitated the dissemination of what might be called a "common concept of nature" across ethnic divides. In other words, neighbors shared similar sets of botanical, zoological, and edaphic knowledge of their region, exchanged in day-to-day communication and encoded in many local religious customs and folklore practices. ${ }^{15}$

\section{From Land Dispute to Property Issue: Reconsidering the "Ground" of Coexistence and Conflict}

Under Ottoman conditions of coexistence, land disputes appear as common forms of conflict between the particular interests of local resource user groups. These conflicts rarely produced ethnic discord; rather they provided reasons for inter-ethnic solidarity. In that way, property disputes of the Ottoman and early British period differ substantially from those conflicts that make up the current "property issue," or the dispute over properties that has emerged since the island's division in 1974. The latter arises from the discrepancies between Turkish and Greek Cypriot estimations of the actual land holdings of their communities, the treatment of the property left behind by the displaced population, as well as the conflicting claims for restitution versus remission of property. Its history is a recent one. To the Turkish Cypriot community, it also echoes the losses of land through colonial intervention, such as the distribution of Evkaf (plural of vakıf, or religious foundation) properties to Orthodox peasants during the early part of British rule; Turkish Cypriot accusations of "land grabbing" during the agricultural reform period; or the sales of Turkish Cypriot properties to Greek Cypriots following the first wave of displacement after 1963. While these modern land disputes seem to have lost the particularity of local neighborhood interests, they convey the impression of uniform ethnic communities with essentially opposing interests in the matter. Since the 1990s, the issue has gained an international dimension through several legal cases against Turkey brought to the European Court of Human Rights by Greek Cypriot individuals, who decided to take measures against their expropriation following their displacement in 1974 (for a discussion of the "property issue," see Scott 1998; Gürel and Özersay 2006; Kyriacou 2009; Trimikliniotis and Sojka 2012).

Still, it is helpful to conceive of the current "property issue" as just a recent facet of the long history of inter-ethnic property relations in 
Cyprus. The issue has lost nothing of its historical complexity and represents the one aspect of the conflict that proves the hardest to solve. There is one feature common to all attempts at restitution, remission, and compensation of property: in order to allow for a smooth transaction, the value of land has to be redefined in terms of its monetary, or market, value. While the commodification of land and houses may seem a practical step toward a solution of individual disputes, the historical, biographical, and deeply emotional baggage associated with these contested properties is not easily eradicated. On both sides of the border, Cypriots continue to "assert a model of property as embodying particular places, social relationships and personal histories in which ... the 'other side' and the idea of the island 'as a whole' play a part" (Scott 1998: 158). The current "property issue" thus reverberates a long history of deep involvement of people with their physical environment, a history that is enmeshed in the fabric of mixed settlements and agricultural networks. Its Mediterranean characteristics as well as the complexity of the Ottoman system of land tenure were central parameters for local configurations of coexistence. The history of Cypriot property relations should therefore be explored for its potential for future solutions rather than seen as an old-fashioned relic of the past.

Irene Dietzel completed her Ph.D. in Religious Studies at the University of Erfurt, where she also participated in the research project "Mobilisation of Religion in Europe." Her latest work focuses on religion and ecology in the Mediterranean. The arguments of the present chapter are further developed in Irene Dietzel (2014), The Ecology of Coexistence and Conflict in Cyprus: Exploring the Religion, Nature and Culture of a Mediterranean Island (Berlin: de Gruyter).

\section{Notes}

1. This applied primarily to the properties that were subject to agricultural use, like fields, gardens, or grazing grounds. Residential patterns, however, displayed a number of ethnic differences in terms of spatial organization. Muslim villages, as well as Muslim family homesteads in mixed villages, were characterized by a larger inner domestic sphere, given the religious reasons for the spatial segregation of women. In contrast, neighborhood relations in Greek villages tended to be maintained in the open (Charalambous 1998). The rural context also differed from the urban settings of the island's towns and villages. Here, spatial segregation of ethnic communities was more prevalent, probably due to the occupational specialization of ethnic communities in distinct crafts and trades (Rizopoulou-Egoumenidou 2009: 234). 
2. In 1960, the proportion of urban to rural population was 38.1 percent to 61.9 percent (of a total population of 573,500 ). In 1973, 42.2 percent of Cypriots lived in urban areas, while the rural population amounted to 57.8 percent (of a population of 631,800) (Brey and Heinritz 1988: 12).

3. A state-appointed judge who rules according to Islamic Law.

4. The fact that internal solidarity of local communities and the tax-paying ability of their villages were closely linked is also emphasized by Hadjikyriacou. The levy of a "lump sum" (maktu) from entire villages thus necessitated a certain level of cooperation, which was in peril when the economic situation was dire (2011: 277).

5. The summary of the Ottoman Land Code is adapted from the works of Harris (2007: 176ff) and Christodoulou (1959: 72ff).

6. See Jennings (1999) on the established property rights of women in the Ottoman legal system.

7. The "commons" are defined here as those natural resources that are accessible to all members of a local community. It has been the subject of a lengthy debate whether all human societies are bound to deplete the commons through actions of unconstrained individual self-interest (Hardin 1968), or whether traditional or indigenous societies have developed mechanisms to protect and maintain them.

8. Colonialists have usually portrayed the phenomenon of shifting cultivation with negative connotations - a fact that reflects a limited understanding of this form of agriculture. French colonialists termed this method "nomadisme agricole," Dutch colonialists called it "roofbouw" (robber agriculture) (Dove and Carpenter 2008: 26). In Cyprus, the British colonialists called this method "fitful cultivation" (Harris 2007: 138).

9. Christodoulou gives the following example: "A holding [of water] here refers to each owner's aggregate holding that is made up of a number of registered rights to irrigation on various occasions in a number of localities within the village area with water from the various divisions of the Kythrea Spring. Such rights are more often held in undivided shares, the co-owners being at times numerous. The largest aggregate holding, amounting to 183 hours every fortnight, is that of a parish church; the least does not exceed 12 seconds in the fortnight. About one-quarter of the owners of water possess neither land nor trees" (Christodoulou 1959: 90).

10. The dönüm is an aerial measurement used widely throughout the Ottoman Empire. In Cyprus it came to denote an area of approximately one thousand square meters. The dönüm was introduced in the mid-nineteenth century in an effort to standardize, replacing the çift as measuring unit for arable land, which defined an area that could be ploughed by a pair of oxen in a day. The çift varied throughout the empire according to the climatic and topographical conditions of the locality (İslamoğlu 2004: 297).

11. The tourism industry grew substantially in the years 1966-67, once the upheavals of the conflict of 1963-64 had ebbed. At that time the number of foreign arrivals to Cyprus increased yearly by 25 percent. The northern coast of the island experienced the fastest growth rates of touristic devel- 
opment. By 1974, the district of Kyrenia had recorded the most land sales (Heinritz 1975: 80).

12. In most cases, the construction of hotels followed after the plot of land had changed its proprietor. The first sales of dry land affected the group of "fulltime farmers"-Cypriot peasants who depended entirely on agricultural work for income. While the land was purchased for its agricultural value, it was resold following a re-estimation of its value for the building and tourist sectors, often at several times the original price (Heinritz 1975: 81-85).

13. The number of Turkish villages left deserted was 112, while Turkish Cypriots left 59 of the 146 mixed villages (Heinritz 1975: 89).

14. Alternative sources cite an even higher number of displaced Turkish Cypriots, estimating a total of 25,000 displaced persons, while only about 2,000 were able to return by 1970 (www.prio-cyprus-displacement.net).

15. In Ottoman Cyprus, local religious practices tended to blur, rather than accentuate differences of ethno-religious belonging. As in other Mediterranean settings, the peasant context of Cyprus holds numerous examples of shared practices of devotion, common places of worship and even entire syncretic communities. For an involved discussion, see Dietzel (2014).

\section{References}

Asmussen, Jan. 2001. 'Wir waren wie Brüder' Zusammenleben und Konfliktentstehung in ethnisch gemischten Dörfern auf Zypern. Studien zur Zeitgeschichte des Nahen Ostens und Nordafrikas, Bd. 7. Hamburg: LIT-Verlag.

Barth, Frederik. 1956. "Ecologic Relationships of Ethnic Groups in Swat, Pakistan." American Anthropologist 58(6): 1079-89.

Bentley, Jeffery W. 1987. "Economic and Ecological Approaches to Land Fragmentation: In Defense of a Much-Maligned Phenomenon." Annual Review of Anthropology 16: 31-67.

Blondel, Jacques. 2010. The Mediterranean Region: Biological Diversity in Space and Time. Oxford: Oxford University Press.

Braudel, Fernand. 1972. The Mediterranean and the Mediterranean World in the Age of Philip II. New York: Harper \& Row.

Brey, Hansjörg, and Heinritz Günter. 1988. Bevölkerungsverteilung und Siedlungsstruktur in Zypern nach 1974. Beihefte zum Tübinger Atlas des Vorderen Orients. Wiesbaden: Ludwig Reichert Verlag.

Bryant, Rebecca. 2004. Imagining the Modern: The Cultures of Nationalism in Cyprus. London: I.B. Tauris.

Charalambous, Nadia. 1998. "Ethnicity and Space." Cyprus Review 10(2): 79-115.

Christodoulou, Demetrios. 1959. The Evolution of the Rural Land Use Pattern in Cyprus: With Land Use Map. Bude: Geographical Publications.

Constantinou, Costas. 2007. "Aporias of Identity: Bicommunalism, Hybridity and the 'Cyprus Problem.' Cooperation and Conflict 42: 247-70.

Delipetrou, P., J. Makhzoumi, P. Dimopoulos, and K. Gheorghiou. 2008. "Сyprus." In Mediterranean Island Landscapes Natural and Cultural Ap- 
proaches, ed. I.N. Vogiatzakis, G. Pungetti, and A. M. Mannion, 170-204. Dordrecht: Springer Netherlands.

Demetriou, Chares. 2008. "Big Structures, Social Boundaries, and Identity in Cyprus, 1400-1700." American Behavioral Scientist 51: 1477-94.

Dietzel, Irene. 2014. The Ecology of Coexistence and Conflict in Cyprus: Exploring the Religion, Nature and Culture of a Mediterranean Island. Berlin: de Gruyter.

Dietzel, Irene, and Vasilios Makrides. 2009. "Ethno-Religious Coexistence and Plurality in Cyprus under British Rule (1878-1960)." Social Compass 56(1): 69-83.

Dove, Michael R., and Carol Carpenter. 2008. "Introduction." In Environmental Anthropology: A Historical Reader, ed. M. Dove and C. Carpenter, 1-86. Malden, MA: Blackwell.

Given, Michael. 2000. "Agriculture, Settlement and Landscape in Ottoman Cyprus." Levant 32: 215-36.

- 2002. "Maps, Fields, and Boundary Cairns: Demarcation and Resistance in Colonial Cyprus." International Journal of Historical Archaeology 6(1): $1-22$.

Gürel, Ayla, and Kudret Özersay. 2006. The Politics of Property in Cyprus: Conflicting Appeals to Bizonality and Human Rights by the Two Cypriot Communities. Cyprus: PRIO Cyprus Centre. (Report 3/2006).

Hadjikyriacou, Antonis. 2011. "Society and Economy on an Ottoman Island: Cyprus in the Eighteenth Century." Ph.D. dissertation. SOAS, London.

Hardin, Garrett. 1968. "The Tragedy of the Commons." Science 162: 1243-48.

Harris, Sarah E. 2007. "Colonial Forestry and Environmental History: British Policies in Cyprus, 1878-1960.” Ph. D. dissertation. The University of Texas, Austin. URL: https://webspace.utexas.edu/gwk/graduate/phdchron.html (accessed May 2010).

Heinritz, Günther. 1975. Grundbesitzstruktur und Bodenmarkt in Zypern: Eine sozialgeographische Untersuchung junger Entwicklungsprozesse. Erlanger Geographische Arbeiten, Sonderband 2. Erlangen: Palm \& Enke.

Herzfeld, Michael. 1980. "Honour and Shame: Problems in the Comparative Analysis of Moral Systems." Man 15(2): 339-51.

- 1984. "The Horns of the Mediterraneanist Dilemma." American Ethnologist 11(3): 439-54.

Horden, Peregrine, and Nicholas Purcell. 2000. The Corrupting Sea: A Study of Mediterranean History. Oxford: Blackwell.

İslamoğlu, Huri. 2004. "Politics of Administering Property: Law and Statistics in the Nineteenth-Century Ottoman Empire." In Constituting Modernity: Private Property in the East and West, ed. H. İslamoğlu-İnan, 276-319. London: I.B. Tauris.

İslamoğlu-İnan, Huri. 1991. "Peasants, Commercialization, and Legitimation of State Power in Sixteenth-Century Anatolia." In Landholding and Commercial Agriculture in the Middle East, ed. Ç. Keyder and F. Tabak, 57-76. Albany: State University of New York Press. 
Jennings, Ronald C. 1993. Christian and Muslims in Ottoman Cyprus and the Mediterranean World, 1571-1640. New York University Studies in Near Eastern Civilization XVIII. New York: University Press.

- 1 1999. Studies on Ottoman Social History in the Sixteenth and Seventeenth Centuries: Women, Zimmis and Sharia Courts in Kayseri, Cyprus and Trabzon. Analecta Isisiana, 39. İstanbul: Isis Press.

Keyder, Çağlar. 1991. "Introduction: Large-Scale Commercial Agriculture in the Ottoman Empire?" In Landholding and Commercial Agriculture in the Middle East, ed. Ç. Keyder and F. Tabak, 1-13. Albany: State University of New York Press.

Kyriacou, Andreas P. 2009. "Property Rights and the Cyprus Problem: Insights from Economics and Social Psychology" Cyprus Review 21(1): 193-98.

Lanitis, Nicholas Constantine. 1992 [1944]. Rural Indebtedness and Agricultural Co-operation in Cyprus. Limassol, Cyprus: Proodos.

Lansing, Stephen J. 1991. Priests and Programmers: Technologies of Power in the Engineered Landscape of Bali. Princeton, NJ: Princeton University Press.

Örek, Osman N. 1971. A Legal Exposé on the Main Points of the Land Consolidation Bill Passed by the Greek Cypriot Administration in Violation of the Republic's Constitution. Nicosia: Public Information Office (PIO) of the TRNC.

Pina-Cabral, João de. 1989. “The Mediterranean as a Category of Regional Comparison: A Critical View." Current Anthropology 30(3): 399-406.

Rizopoulou-Egoumenidou, Euphrosyne. 2009. "Traditional Craftsmen in Cyprus during the Period of Ottoman Rule, through Lists of Property of Deceased Persons." In Ottoman Cyprus: A Collection of Studies on History and Culture, ed. M.N. Michael, 231-57. Wiesbaden: Harrassowitz.

Schnabel, Susanne. 2004. Sustainability of Agrosilvopastoral Systems: Dehesas, Montados. Reiskirchen: Catena-Verl.

Scott, Julie. 1998. "Property Values: Ownership, Legitimacy and Land Markets in Northern Cyprus." In Property Relations: Renewing the Anthropological Tradition, ed. C.M. Hann, 142-59. Cambridge: Cambridge University Press.

Shaw, D.J. 1963. "The Problem of Land Fragmentation in the Mediterranean Area: A Case Study." The Geographical Review 53(1): 40-51.

Tabak, Faruk. 2008. The Waning of the Mediterranean, 1550-1870: A Geohistorical Approach. Baltimore, MD: Johns Hopkins University Press.

Trimikliniotis, Nicos, and Bozena Sojka. 2012. Envisioning a Future: Towards a Property Settlement in Cyprus. Cyprus: PRIO Cyprus Centre Report 7/2012. 
2. Chapter $2 \cdot 6$

\title{
Intersecting Religioscapes in Post-Ottoman Spaces
}

\author{
Trajectories of Change, Competition, \\ and Sharing of Religious Spaces
}

ROBERT M. HAYDEN

\section{Introduction}

$\mathrm{T}$

he term "post-Ottoman space" seems to be unproblematic: places that had been part of the Ottoman Empire, but then ceased to be so. Yet the matter is hardly simple. The Ottoman Empire, like many other polities, expanded and then contracted. Thus Pecs, Hungary, and for that matter, Budapest, which were within the Ottoman Empire at its farthest reaches in central Europe in the late seventeenth century, should be considered as much post-Ottoman space as the Balkan territories that were the last to be "liberated," in 1912, even though Ottoman rule in Hungary and Croatia ended more than two centuries earlier than it did in Macedonia and Albania. At the other extreme, we cannot speak of "Ottoman space" before there was at least an Ottoman state, if not yet empire. This means that we must look at the varieties of transformations of the first Ottoman capital, Bursa, over a very long period-from 1326 until the end of Ottoman rule there, first by the Greek occupation in 1920-22, then by the achievement of control there by the forces of the new Turkish state, as well as the abolition of the Sultanate in 1922 and the founding of the Republic in 1923. There was not simply an Ottoman Empire and then post-Ottoman period, even in that one city. The variations in historical periods, national groups, and other elements of Ottoman history are at least as complex as those of any other major empire, so looking for commonalities in the making and unmaking of space as "Ottoman" from Budapest to Basra, and from Sarajevo to Kars, would 
seem an impossible task, even were we not to consider the historical trajectory of a single place, like Bursa from 1326 through 1923.

Yet there was a common way of marking a territory as Ottoman, from the very start of the Empire. From the founder of the dynasty, Osman, through the last Ottoman Sultan, Mehmed VI, the Ottoman ruler was a Muslim and the Ottoman state was grounded on Islam. This was nothing unusual, of course. From the very beginning of Islam, Muslims confronted Byzantium, and Muslim leaders who became rulers did so by conquering territories ruled until then by Christians (Evans and Ratliff 2012). The Christian populations did not disappear, but they were subordinated to Muslims, and this subordination took the form of, among other things, imposing physical signs of the superiority of Islam on landscapes that had until then been marked by signs of the superiority of Christianity. With the weakening or collapse of Ottoman authority in various regions of the Balkans, as shown below, these markers of Muslim dominance were supplanted by markers of Christian dominance. This means that there were common ways of marking territory that became Ottoman, on the one hand, and post-Ottoman, on the other, reflecting the fact that the Christian and Muslim populations were engaged in what a Bulgarian historian, analyzing four hundred years of interaction between Muslims and Christians at key religious sites in the former Bulgarian capital of Veliko Tarnovo, calls "mutual provocation" (Parveva 2002: 52), a pattern of interaction that my colleagues and I have defined more generally as "antagonistic tolerance" (Hayden 2002), explained below.

Other chapters in this volume examine forms of difference such as gender and class, rather than religion, and Rebecca Bryant in her introduction reminds us of Karen Barkey's argument that the Ottoman Empire valued differences. Bryant also notes that the extent to which religious distinctions mattered in daily life "differed between village and town, between center and periphery, and between different periods of Ottoman rule" (this volume, p. 13). Yet it is necessary to recall that there was a hierarchy of statuses, using the model of hierarchy proposed by Louis Dumont and recently reinvigorated by Joel Robbins, in which the superior value encompasses the inferior one (Dumont 1980; Robbins and Siikala 2014). In the Ottoman Empire and in post-Ottoman spaces, the religious identity was superior to the others, in that each of these others was encompassed within it. For example, a woman would rarely be seen as only that, but would of necessity be regarded by others, and regard herself, as a Muslim woman, or a Christian one, or a Jewish one, to give major classifications; there are other possibilities within these larger categories (Baumgarten 2008; Green 2008). Similarly, peasants 
were not just a single category of tax-paying common people; they were also grouped as Muslims or alternatively, as various specified others, who were subject to taxes not imposed on Muslims. While patterns of interaction varied between city and countryside, this seems also to have involved individuals dealing with each other as members of religious communities. Minority communities sometimes had greater autonomy in the countryside than in cities, but their autonomy was tenuous since there could still be overriding involvement from the metropolitan center (Catlos 2014).

Differences between members of different religious communities in formerly Ottoman spaces were and are marked by names, some food prohibitions, following different ritual calendars, and overwhelmingly, endogamous marriages. In this last category, while Muslim men could take non-Muslim women as wives, the reverse was not true. Furthermore, conversion could only be into Islam, conversion from Islam being strongly negatively sanctioned. Focusing on the changing formations of religious dominance is thus not only a way to identify Ottoman and post-Ottoman spaces, but also to identify a primary social category that encompassed other elements of identity, which were subordinated to religious identity.

Of course, recognizing the importance of the categories of religious identities reinforced in multiple ways is not to assert that there is some essential quality to any of them, but rather only to recognize the importance of social phenomena: people themselves used these categories, apparently believing in their validity even as they may often have adopted cultural practices from each other. In this regard, I must question the position asserted in some other chapters in this volume, that the borders between the religious communities were "blurred" when members identifying themselves as belonging to different religions interacted. A leading researcher in the field summed up the findings of a volume on sharing religious sites in the Mediterranean by saying that "while the hybrid practices are striking, mixing with individuals of a different religion does not result, so to speak, in any evident damage to existing religious identities. Indeed, these 'transgressions' usually appear to be associated with the original religious polarization" (Albera 2012: 243). Such continued "polarizations" are a common finding of researchers on sites shared by members of different religious communities.

Sharing of sites does not mean sharing of identity. I am reminded of the Ottoman-era tombstones exhibited inside a Bulgarian museum that in situ had shown Muslim names in the Arabic script above ground, but also carried crosses with Christian names, in Cyrillic, below ground, both names referring to the same person. Even obvious syncretism does 
not lead to shared identities. Observational studies of Christians and Muslims at shrines frequently attended by members of both groups have been very clear: from Hasluck in 1913 through very recent studies in Bulgaria nearly a century later, members of these communities maintain their separate religious identities, and avoid engaging in some of the characteristic forms of worship of the other religion. As one recent study put it, at sites in which members of two or more religious communities interact, "[c]ooperation between believers from different religious traditions should not be mistaken for religious syncretism. Deep down, this ... is a cultural strategy developed by members of both groups for anti-syncretic purposes, that is to preserve the religious autonomy of each group" (Lubanska 2013: 107). We have no reason to believe that such strategies were different in the Ottoman period.

If we pay attention to the processes of marking and unmarking Ottoman space through manifestations of dominance of Islam or Christianity, we are forced to consider the circumstances under which they take place, and thus also the trajectories of relations between the religious communities. Seen in this light, "peaceful coexistence" is not so much a condition that can be disrupted, as a manifestation of relations at times when the dominance of one group over another is so firmly established that it need not be imposed, and cannot be much countered. By focusing on the physical forms used to mark dominance, we can also trace the trajectories of domination and its decline, and thus of periods of peaceful interaction with those of contestation.

\section{Marking and Unmarking Space as Ottoman}

Let us begin with the very start of Ottoman rule in Bursa. Osman died two years before Bursa was captured, but his son and successor Orhan had him buried in the most prominent building of the formerly Christian town, the "silver dome" of a monastery complex (Çağaptay 2011: 52-53). Upon his own death, Orhan was buried in the main church of the same complex (Ibid.). Çağaptay argues that the early Ottomans thereby "transferred the confessional loci" in the city by adapting these Byzantine religious structures into their developing Ottoman design. In so doing, she argues, the Ottomans were demonstrating conquest and power, but also incorporation of Christian elements into their empire (Çağaptay 2011: 64-65). Thus we have apparent syncretism, but in an effort to persuade Christians to accept the legitimacy of Muslim rule and even, possibly, emphasize the continuity of Islam with Christianity. 
Such appropriation of the most prominent Christian structures was a common feature of Ottoman conquest, as seen at Constantinople in 1453, Belgrade in 1521, and Pecs in 1545. In all of these cases, literally the first action of the conquering Ottoman (Mehmet II in Constantinople, Suleyman in Belgrade and Pecs) was to convert the largest church into a mosque. Thereafter, in all of these cases, the city soon came to be dominated by mosques and other structures associated with Islam, and in ways that quite literally imposed Muslim dominance on the cities.

The early Ottoman development of Bursa has recently been studied using advanced geo-spatial technologies. Employing GIS data and various mapping techniques, a Turkish-Japanese research team found that the first Ottoman mosques were placed so as to maximize their visibility throughout the city. These researchers suggest that the Ottoman emperors controlled the city through the strategic placement of mosques in what had been a Christian city (Dostoğlu et al. 2004). A later publication by members of the same team argued that not only was one of the largest mosques built on a site of high visibility, but that after the mosque was built the road network was altered to increase the mosque's visibility even further (Kensuke et al. 2004).

Çağaptay sees the transformation of Bursa as a model for later Ottoman adaptations of conquered Christian towns, in the region and beyond. Another tendency was to build outward from the old town in ways that were more clearly Muslim in origin and did not connect to the Byzantine past. In fact, Bursa's contested history continued: the Greek army conquered it in the invasion of 1920 and held it as their headquarters until their defeat and withdrawal in 1922. We know that they reconverted Byzantine churches that had been converted into mosques in nearby towns such as Trilye/Triglia and Iznik/Nicea, but we do not have details of those conversions, which were in any event reversed after not only the Greek army but the Christian civilian population was driven out in 1922-23 (Hayden et al. 2011). Remarkably, however, in October 2012, renovations in the Muradiye Mosque (1426) in Bursa revealed blue stencils of Greek flags under the whitewash, obviously from the time of Greek rule in 1920-22, but unknown until now (personal communication from Dr. Tuğba Tanyeri-Erdemir, 13 October 2012). These Greek national icons indicate that the Greeks converted the mosque to their own use at that time.

Since marking a space as Ottoman involved imposing a Muslim identity on major Christian structures within it, and then expanding the visibility of Islamic structures in a town, the reverse process also held true: de-Ottomanization (at least outside the territory of today's Turkey) was 


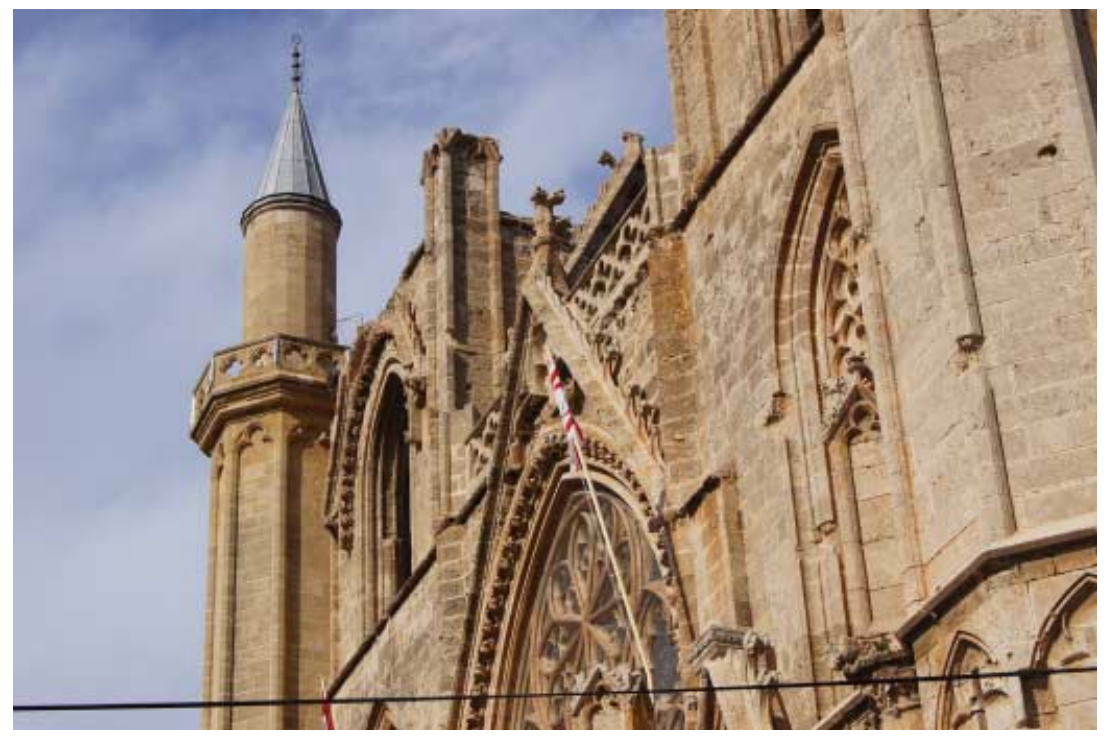

Figure 2.1. Minaret on the fourteenth century St. Nicholas Church in Famagusta, Cyprus, converted into a mosque after the Ottoman conquest in the sixteenth century. Aya Sofya mosque until 1954, then renamed Lala Mustafa Paşa Mosque (photo by Robert M. Hayden, October 2011).

marked by replacing the dominance of Muslim structures by dominant Christian ones.

The case of Pecs is interesting. The Mosque of Kasim Pasha was built between 1543 and 1545 on the site of what had been St. Bartholomew's Church and using the stones of that church, but was (re)converted into a Catholic church when the Ottomans were forced from Pecs, and remains such today (Bachmann and Bachman 2010). This was hardly an unusual case. In Belgrade, following the 1521 Ottoman conquest, every church was destroyed or converted until the Hungarians took the place in 1688 and then all mosques were converted or destroyed. After the Ottomans took it again in 1690 they repaired the damaged mosques and built a new one; but when the Austrians took the city in 1717 they promptly destroyed the mosques or converted them. The Ottomans returned in 1739 and again tore down churches while setting up mosques; the third Austrian occupation from 1789 to 1791, again saw the destruction or conversion of mosques, until the final Ottoman conquest of Belgrade in 1791 led, again, to the repair of mosques and the destruction of churches. Among the very first actions taken by Karađorđe, the leader of the First Serbian Uprising, when his troops took control of Belgrade in 1806, was to convert the largest mosque into an Orthodox church. 


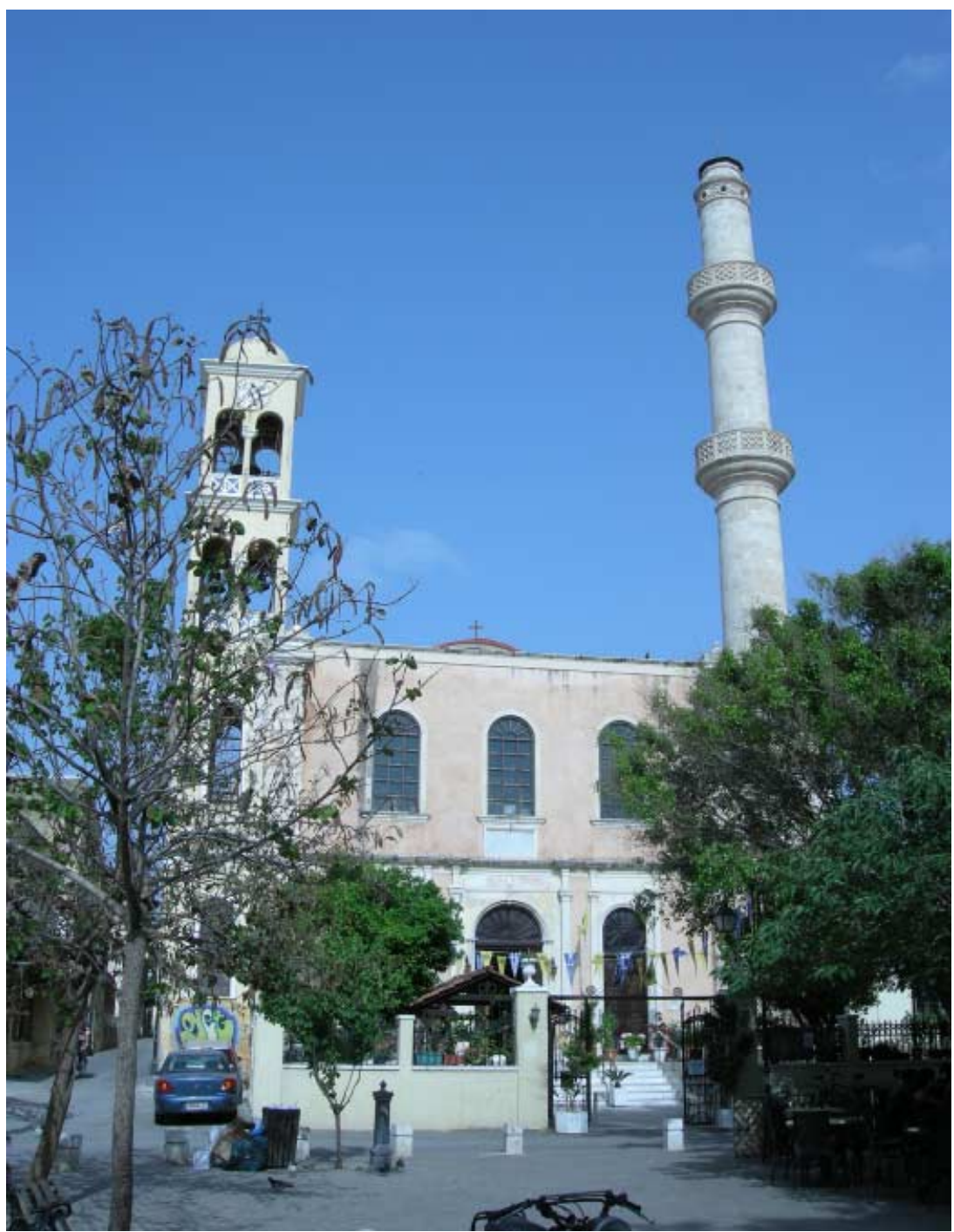

Figure 2.2. St. Nicholas Church, Chania, Crete. Venetian fourteenth century Catholic church, converted into a mosque by Ottomans in 1645, then into a Greek Orthodox church in 1918. Note truncated minaret (photo by Robert M. Hayden, May 2015).

While that uprising was suppressed in 1813, with Belgrade retaken and the church reconverted into a mosque, with the establishment of the Serbian principality in 1830 the power of the Ottomans was in decline, so that when they were finally forced to abandon Belgrade in 1867, only 
one small mosque remained in operation, and remains so today (on all of this history, see Hayden 2005).

Sofia, Bulgaria, saw a history similar to that of Belgrade, with the Ottomans destroying churches or converting them into mosques, and the newly liberated Bulgarian state destroying mosques or converting them into Bulgarian Orthodox churches (Hayden et al. 2011). Such cycles of destruction/conversion/reconversion were not limited to capitals. One of my favorite examples is the present-day Church of the Resurrected Christ in Čačak, Serbia. The church still has visible signs of its last incarnation as a mosque between 1738 and 1805; but between 1560, when the first mosque was built on the site by destroying a church there, until 1738, the town changed hands numerous times and the building went through several cycles of transformation from mosque to church and back again (Rajić and Timotijević 2011).

What marked a space as Ottoman, then, was the imposition of Muslim religious structures in primary locations in the town or city concerned, while marking it as no longer Ottoman involved displacing these Muslim structures with Christian ones. This does not mean that, in either case, all of the religious structures of the group that was suddenly subordinated would be transformed or destroyed. On the contrary, we know that very soon after taking Constantinople, Mehmet II issued orders giving rights to the remaining Greek population and protecting many of their churches (Inalcik 1969/70), and even though the Hagia Sophia was immediately converted into a mosque, some of the Christian iconography on the walls remained for decades afterwards (Necipoğlu 1992). One small Byzantine church in Istanbul, St. Mary of the Mongols, was never converted and remains functioning as a Greek Orthodox church. Similarly, in Belgrade and Sofia, there are still functioning Ottoman-era mosques, albeit small ones. In Triglea/Trilye, already mentioned, the Ottomans did indeed convert the largest of the Byzantine churches there into a mosque in the sixteenth century, but five other large churches remained functioning in a town that was overwhelmingly majority Christian until the "population exchange" of 1923 forced the Christian population to leave for Greece (Hayden et al. 2011).

Being marked by the Ottoman conquest in all of these places was Muslim dominance over Christianity; this was the primary indicator that a space was indeed Ottoman. And when a territory was brought out of Ottoman rule, the physical markers of Muslim dominance-mosques, minarets, türbes, and other structures-were destroyed or displaced by more prominent Christian structures: churches, bell towers, and the like (see, e.g., Mišković 2011 on the transformations of urban space in 
Belgrade during the transition from Ottoman to Serbian national rule). This form of marking was constant, from the beginning of the empire until past its end, and this consistency through time provides a means to analyze the coexistence of the religious communities in the Ottoman period, by considering the physical structures associated with each: their distribution through time, and their features as indicators of dominance. These are brought together in the concept of religioscape, the distribution in spaces through time of the physical manifestations of specific religious traditions and of the populations that build them, as explained below. First, however, it is necessary to consider what we mean by saying that space is "shared," peacefully and less so.

\section{Antagonistic Tolerance: Competitive Sharing, Dominance and Intertemporal Violence}

My analysis differs from that of others in this volume because it draws on concepts developed in the course of a five-year, multi-disciplinary, and comparative research project on competitive sharing of religious sites, which my colleagues and I have carried out via field research in Bulgaria, India, Mexico, Peru, Portugal, and Turkey, with substantial reference to library resources on other places (see Hayden 2002; Hayden et al. 2011; Hayden and Walker 2013; Hayden et al. 2016; and the website of the project, http://www.ucis.pitt.edu/antagonistictolerance/AT_Main_ Page.html). We have developed a model of "antagonistic tolerance" (hereafter, AT) to explain long-term patterns of relationship between members of groups who identify themselves and each other as Self and Other communities, differentiated primarily on the basis of religion, living intermingled but rarely intermarrying (Hayden 2002). The religious distinction is often accompanied by other differences, such as in naming, kinship, diet, and perhaps preferred methods of gaining a livelihood. In this model, which was inspired by the work of F.W. Hasluck (1973 [1929]), contestation develops in a region in which one religious tradition is dominant when a community identified with a differing religion arrives via trade or indigenous development.

The AT model holds that in such situations, there is "tolerance" in the sense of enduring the presence of the other but not embracing it, so long as one group is clearly dominant over others. Such dominance is indicated in part by control of the primary identity of major religious sites. However, when existing dominance is threatened, violence results, and violence often accompanies the transformation of sites, which may hap- 
pen when one group replaces the dominant position previously held by another. The processes involved are long-term, though transformations may take place in short periods.

A key feature of this model is consideration of the dominance of one religious community over another, or over others, and of contestations for dominance; we do not regard religion as likely to be irrelevant politically in any situation in which large groups self- and Other-identify as different communities. Religious dominance is marked by control over key religious sites, and the attainment of dominance leads to the transformation of such places. The transformation of Hagia Sophia in Istanbul from a church into a mosque, or the conversion of the great mosque of Cordoba into a church, are obvious examples; but the mosque in Cordoba stood in the place of the Gothic Christian church, which had replaced the Roman Christian one, which had replaced the Roman temple. It is important to note that, often, members of a subordinated community may visit religious sites claimed by the dominant one, and even perform some observances there. Syncretism may arise from such sharing, even though dominance of one group over the other is clear.

The AT pattern is also one of intertemporal violence, either at times when an existing structure of dominance of one group over others is threatened or when existing dominance has been overturned. We adapt the term intertemporal in part from economics, where it refers to dynamic decision making in regard to investment and consumption over the course of a period of time, so that the present state of, for example, an investment account is the result of a series of forward-looking decisions made at earlier times. In international and comparative law, intertemporality refers to the differences between the legal rules applied to a factual situation at an earlier time and those applied at the time of analysis, so that, for example, a decision granting ownership of property to a party at an earlier time is not ordinarily challengeable later on the grounds that the law changed ex post facto.

In the AT model, we envision relatively stable manifestations of dominance that are both adjusted and reinforced by changes attempted by the parties with greater or lesser success (drawing on the economic meaning of intertemporal) but also liable to sudden transformations when a change in dominance is effected (drawing on the legal meaning of intertemporal). Thus the model is akin to what biologists describe as punctuated equilibrium, as that term has been adopted for religious studies by Mark C. Taylor (2007: 27): "periods of relative stability and gradual change are interrupted by phase shifts that lead to structural and morphological transformations." Even then, in many cases, violence is likely to be only that which is necessary either to re-establish the ear- 
lier dominance or to put in place the dominance of another group. After that, relations between the communities involved may continue relatively peaceably for centuries (see, e.g., Hayden et al. 2011).

Critics of the AT model generally disregard the intertemporality of social relations between members of religious communities, preferring instead to isolate specific brief periods in historical trajectories for analysis and largely ignoring what has occurred before and after. They also analyze individual shrines as if they were isolated from other such sites, focusing on what they see as primarily local actors. Such analyses reflect the traditional anthropological framing of imagining an ethnographic present and a locally delimited community. Yet they also manifest the conceptual weaknesses of structural-functionalism, presuming stasis in social relations among local communities and unable to deal with change except as disruption of this static condition by the intervention of outsiders.

Glenn Bowman's critique of the AT model through analysis of relations between members of different Christian churches at the Church of the Holy Sepulchre in Jerusalem (Bowman 2011b) exemplifies this tacit revival of structural functionalism. He posits an "existential consanguinity ... when people live in relatively close proximity, engaging with each other in quotidian activities" except when this is disrupted by external religious leaders. He also says that "[e]ven manifestations of apparent hostility between local Christians of different denominations, such as the ritualised 'fights' which take place between Armenians and Greeks ... are traditional charades played out between men who, on the street, are friends." Since Radcliffe-Brown (1965: 179) defined the function of any recurring practice (here, the "ritual fights") as the role it plays in maintaining the social structure (the "set of relations amongst unit entities," here the "existential consanguinity" of local Christians), Bowman seems to have re-invented structural-functionalism. I understand the normative appeal of seeing interaction within shrines as being determined primarily by the traditions of sanctity that mark them as sacred to a local community that supposedly operates in harmony unless it is disrupted from the outside. However, to do so is to make the same mistake as the structural-functionalists did when they analyzed the inherently stabilizing effects in local communities of "tribal" institutions (e.g., kinship, law) without making reference to the institutions of the larger colonial states that set the parameters on what the natives could do.

At the same time, ignoring the intertemporality of social relations between members of different religious communities also permits critics of the AT model to ignore the reality of these communities as corporate groups. Rogers Brubaker's dismissal of putative "groupism" has been 
used to criticize the AT model (Henig 2014), but it is difficult to deny that religious communities existed as corporate groups in the Ottoman and post-Ottoman period. That individuals act in the name of corporate groups hardly negates the importance of considering the group as a social actor, without assuming that the corporate group is internally homogenous or is composed of "unitary collective actors with common purposes" (Brubaker 2004), though further discussion of Brubaker's model lies outside the scope of this chapter. Corporate groups, of course, are in principle immortal, so an intertemporal frame of reference is needed to accommodate their relevance before, and after, any particular ethnographic present, period of conflict, or post-conflict configuration. By the same token, saying that the AT model sees periods of peaceful interaction as "only temporary" misses the point that we always anticipate change-neither peaceful interaction nor conflict are permanent conditions, and in fact, we see the longer periods as being those of peaceful interaction.

I should also make clear our view of the connection between religion and violence. It has become popular in policy and political science circles to emphasize the differing worldviews of various religions, which by definition are at variance, to say that violence is inevitable between members of different religions, and that conflict at "contested" religious sites is inevitable, intractable, and impervious to a rational solution (Atran et al. 2007; Ginges et al. 2007; Hassner 2009; Atran and Ginges 2012). In part this position rests on a confusion between the necessarily totalizing worldviews of religions, which tend to explain the world in toto, (i.e., without remainder), with the political reality of a modern totalitarian state (Bakić-Hayden 2002: 65-67). In fact, among the latter, only a few attempts have been made to completely eradicate religion (in the name of socialism, with the possible exceptions of the early years of the USSR and of Albania among European socialist states) or even particular minority religions. Even the Islamic Republic of Iran tolerates Judaism and Christianity, albeit antagonistically, since demographically and otherwise the members of these communities do not pose any threat to it.

We see violence as likely only when dominance is under contention and must be either acquired or (re)inforced. We also do not see religion per se as inherently linked to violence, despite the fact that violence is present in many a holy book. Rather, religion may be the key identifying factor associated with a community and thus accepted as defining that group as opposed to others. The importance of such distinctions, while potentially strategic, are not static but may be subject to change with new circumstances, reflecting their intertemporality. For example, Bowman (1993) has shown how Christian and Muslim Palestinians unite at 
a shrine shared by members of both groups in the face of oppression of both communities by the Israeli state, but that when Israeli occupation was briefly lifted following the Oslo accords, the Muslims and Christians became much more opposed under the Muslim-dominated, and Muslim-favoring, governance of the PLO (Bowman 2001).

\section{Shared Space: Overlapping Religioscapes and Indicators of Dominance}

This brings us back to the nature of the "space" that we can call Ottoman or post-Ottoman, and how it was shared. In the AT model, we refer to groups that live intermingled, and our own initial conceptualization was of individual sites in localities (neighborhoods, towns) where members of different groups may live in the same neighborhoods, or in adjacent neighborhoods. As our research progressed, however, we saw that it is better to view shared religious sites as nodes in structures of social interactions between populations that distinguish themselves and each other as different, on religious grounds, through time. As a node, a single site is not isolable from the social networks that interact at it. Thus a Muslim site should be seen as linked to other Muslim sites, a Christian site to other Christian sites, and all at varying scales. Scale here may range from local communities to regional networks to those on a state or imperial scale, and even between states/empires.

In our usage, "religioscape" refers to the distribution in spaces through time of the physical manifestations of specific religious traditions and of the populations that build them (Hayden and Walker 2013). Both the population and the physical manifestations of the religion are components of a religioscape; a physical artifact associated with a religion that is no longer practiced may be evidence of a previous religioscape but does not itself constitute a religioscape. Religioscapes as we define them are inherently fluid: people move, taking their religious practices with them, and potentially change the built environment, too, in ways that reflect their beliefs. Yet the religioscape also reflects the connections between people who regard themselves as holding the same beliefs, or are regarded by others as doing so. The religioscape, then, is a social space marked by physical icons, from small shrines to large complexes of them, or even sacred cities. Indeed, complexes of places, or even territories, may be imbued with religious meaning.

The situations we are interested in are those in which two populations distinguished by differing religions inhabit the same territory. In such cases, their religioscapes intersect, and the power relations of the two 
groups will be displayed by features of the sites relative to each other. In our work, we have identified two indexes of empirical indicators of dominance, centrality and perceptibility. Centrality refers to location within a settlement, or perhaps proximity to locations of important economic or political activities. ${ }^{1}$ Perceptibility refers to features of a structure that make it more perceptible: height, mass, color, projection of sound are examples. In all cases, the greater the indicator, the higher the assertion of dominance. Thus a building that is more centrally located is likely to belong to the dominant community, as is a building that is taller, or broadcasts sound better, or is more colorful than a nearby building of another religious community. Centrality and perceptibility are co-relevant factors, meaning that a shrine may exhibit a combination of these attributes. A massive building with a high tower and amplified sound in the center of a settlement would be dominant, but as these factors vary, dominance may be challenged. A primary finding of our comparative research, however, is that centrality is the key factor in indicating dominance. That is, a religious structure that is at a central location is presumed to reflect dominance over shrines at less central positions.

We can give some concrete examples from spaces that were soon to be, or had just become, post-Ottoman. Let us start with one of the most important indicators of perceptibility, height. Building churches was generally prohibited in the Ottoman Empire, but it was possible to "repair" older ones. Even so, churches could not be as tall as mosques and were generally on the periphery of settlements that also contained mosques (Gradeva 1994), and could not have bell towers; indeed, even clock towers were resisted by many Muslims in the late Ottoman period because they were said to resemble church bell towers (Uluengin 2010). When the Ottoman Empire was losing its ability to govern in Bosnia and tried to appease the Serbian population in Sarajevo by permitting the construction of a large Orthodox church, the dedication of the church (1872) was protected by 1,200 Ottoman troops, with cannon positioned to bombard the city should trouble break out from among the local Muslims, who were protesting not only against the construction of the church, but especially against its having a bell tower (Donia 2006: 33-35). Among the first actions taken after the end of Ottoman rule in 1878 in both Bosnia and Bulgaria was that bell towers were added to churches, as can be seen in the old Serbian church in Sarajevo (sv. Arhandela Mihaila $i$ Gavrila) and the 1859 cathedral in Plovdiv (sv. Bogoroditsa), both of which received bell towers in 1880. Another example from northeastern Bulgaria: near the center of the town of Suvorovo in northern Bulgaria, a mid-nineteenth century church faces a sixteenth-century mosque. The town now has a Christian majority, though it had a Muslim majority 
under Ottoman rule. The minaret of the mosque is taller than the bell tower of the church-but the minaret is topped by a cross, an unusual feature (to say the least!) that both Christians and Muslims will point out to visitors. Close-up pictures reveal that what looks like a cross from the ground is actually a fleur de lis, quite an ambiguous symbol, and while doubtless most townspeople know this, the general acceptance of the icon as a cross acknowledges the local supremacy of the Christian population of the town.

The interplay between centrality and perceptibility can be seen in Plovdiv (Turkish: Filibe), Bulgaria, a former capital city and one of the first parts of Bulgaria conquered by the Ottomans. The main Friday mosque, the Muradiye, built apparently in the 1420s (Boykov 2009), ${ }^{2}$ is in the center of the Ottoman town and actually the center of the place since the Roman period: the mosque perches literally on the edge of a Roman amphitheater. Almost due east, up a hill via ulitsa Saborna (Cathedral St.), is the Cathedral of the Holy Mother of God (sv. Bogoroditsa), an 1850s church with a bell tower added in 1880, two years after Ottoman rule ended. The church is large, and taller than the mosque, but it is removed from the center of the town. Even then, looking back at the mosque, one sees that the minaret is at the same level as the church, and until an earthquake in 1928, the minaret was actually higher than the roof of the church-which makes the erection of the bell tower, even taller than that, very understandable.

Other evidence on the importance of centrality can be seen in Razgrad, also in northeastern Bulgaria, and still the center of one of the few remaining concentrations of Turks in Bulgaria (Sözer 2012). The sixteenth-century Ibrahim Pasha Mosque, one of the largest mosques in the Balkans, is in the center of town. As of 2008, the mosque had been closed for decades, which means that even though it is in the center of the town, that center is denied to the Muslims, as sacred space; they are limited to using a much smaller mosque outside the city center (Hande Sözer, personal communication, 14 November 2012; see also Keil 1991). Meanwhile, the 1860 St. Nicholas Church, on the outskirts of the town when it was built (presumably without a bell tower), was massively reconstructed (and a bell tower added) after the official independence of Bulgaria, and again immediately after the fall of communism. Since the town center is denied to the dominant Christian community (the Ibrahim Pasha Mosque being too large and well-known to permit its destruction), the Muslims are denied use of it as well.

Dominance, though, is local, as can be seen in the one region of Bulgaria in which ethnic Turks form a majority, around Kardjali/Karcali (see Sözer 2012). The town itself is under the political control of the 
main Turkish political party in Bulgaria, the Movement for Rights and Freedoms [Hak ve Özgürlükler Hareketi], and is one of the very few towns in Bulgaria in which an Orthodox church is not located in the center, but there is a mosque there. In the nearby town of Benkovski, which has an almost exclusively Muslim population, is not only one of the oldest mosques in the region (recently renovated as of 2008) but also one of very few, if not the only, churches from the Tanzimat period that is abandoned. When we saw it in July 2008, not only was the church empty (though it did bear a sign saying it would be renovated), but the church yard was being used to dry tobacco, the local cash crop. This empty church would not be so surprising were it not for the fact that so much effort and money has been put into renovating other churches from the period, which are often referred to as "liberation churches" and are seen as having been central to the Bulgarian national movement in the nineteenth century. Indeed, a mural from the 1950s in the Plovdiv Cathedral of the Holy Mother of God depicts a Turk whipping a crying woman, a city dweller, and a priest, all in chains and at the head of a column of other Bulgarians, with the title of "the church and the nation in the struggle for liberation." Thus the local dominance of the Turks in Kardjali lets them maintain mosques in the center of towns there, but they are on the south-eastern periphery (the Greek border) of a postsocialist Bulgaria defined very much in terms of its Orthodox Christian heritage-with St. Ivan Rilski, carrying a cross, appearing on the one-lev coin in use in the post-communist period.

By evaluating the nodes of religioscapes in accordance with the indicators of centrality and perceptibility, we can get a very good picture of which group is dominant at any given moment in time for which we can obtain the relevant data; and by looking at the changing nodes of religioscapes through time, we can assess the development of dominance by religiously-defined groups as well. To give the simplest of examples, a map of religious sites in Sofia shortly before 1878 would have indicated two small Orthodox churches near the Market Mosque and the Banya Başı Mosque, much smaller and lower than either of them; an 1867 stone church without a bell tower (St. Nedelya) nearby; slightly farther way and on a hill was the sixth-century St. Sophia Church for which the city was named but had been converted into a mosque; and there was also a large mosque on another nearby hill, the Kara Camii (Black Mosque). In terms of our indicators, the Muslim religioscape shows dominance: the mosques were all larger than the churches, and on higher ground. However, a map today would show the reverse: the two small Christian churches remain, but the former Market Mosque is now the Museum of the Archeological Institute of the Bulgarian Academy of Sciences, 
the former Black Mosque has been transformed into the Church of the Forty Martyrs, the St. Sophia church is once again a church, and there is a larger St. Nedelya, erected in 1933 to replace the earlier one (which had gotten a bell tower in 1879), plus the second-largest cathedral in the Balkans, the Aleksander Nevsky Cathedral, planned in 1888 and built in the first decade of the twentieth century, on a point even higher than St. Sophia and the Forty Martyrs Church. The Muslim religoscape still exists, but is much reduced in size, and the remaining nodes on it are dominated by the nodes of the Orthodox Christian religioscape, in terms of height, elevation, size and amplification of sound. On this last point, the churches have bell towers, but the mosque is not permitted to amplify the call to prayer.

\section{Intersecting Religioscapes}

Most intriguing, perhaps, are those situations in which two religioscapes intersect, in that a single site is claimed as a node on each of them. Saints' shrines are common places of such overlap, from India (where a saint may have both a Hindu identity and a Muslim one, and be venerated as such by members of each group [Hayden 2002]) through the Balkans and indeed, the wider Mediterranean world (see Albera and Couroucli 2012; Bowman 2012). The AT model anticipates such intersections, drawing on Hasluck's analysis that "ambiguous shrines," those shared by members of more than one religion, represented a "period of equipoise" in the relations of power between them. To us, what is most interesting is to analyze the trajectories of the development of the differing religioscapes that can turn a site from belonging to one group, through the period of equipoise when it is also claimed by another, to perhaps a stage in which the first group has been largely displaced.

Such a site can be seen in Obrochishte, in northeastern Bulgaria, in what was clearly built as the türbe of a Muslim saint and has long been identified as the tomb of the saint Ak-yazul Baba. The site has been a museum since at least the communist period, and a booklet from the time (Margos n.d.) presents a straightforward archaeological and historical analysis of the site, as having been built in the sixteenth century and being similar in design to other türbes in the region. There was also a dervish connection: the site has not only the tomb (türbe) but also an additional building which Margos (n.d.) identifies as an imaret (soup kitchen) or a tekke. The latter seems more likely, since Margos reports that in 1884 (thus six years after Bulgarian independence) a Czech historian visited the site and found one remaining dervish. It is also possible 
that the site was Alevi or Bektashi, and the second building a cem hall, though, as Hande Sözer (2012) has shown, the Alevi presence among Bulgarian Turks often passes unnoticed.

In any event, there seems little reason to doubt that the site was built for the use of Muslims, during the Ottoman period. By the time of our visit in 2008, however, while the site was still officially a museum, the usual internal trappings of the türbe of a sufi saint were accompanied by Christian icons, as well as by crosses, ${ }^{3}$ and the site was identified by the museum employee on duty as actually being that of a Christian saint, Atanas, the "good friend" of Ak-yazul Baba, rather than of the Baba himself. In fact, the identities of the saint(s) were merged in the telling, with the ultimate climax of the story being that Atanas had been so unfortunate as to fall in love with a Muslim woman, something that was prohibited and thus led to his execution. Ak-yazul Baba, heartbroken, knew that to build a tomb for his friend would not be permitted by the Ottoman rulers, so in one night he built the türbe, saying it was a tomb for himself, but actually burying Atanas there and then leaving the place.

The website of the museum, now called the "Monastery of Akyazala Baba-St. Atanas," does not tell this story but refers to the place as "The bi-ritual prayer house of the Muslim saint Akyazala Baba and of his Christian counterpart St. Athanasius," in contrast to the booklet from the communist period, which referred only to the Baba. The website identifies the site as having been built as a Bektashi tomb in the sixteenth century but that in the late nineteenth century it became a "biritual sanctuary" visited by Muslims and Christians, presumably following Bulgarian liberation from Ottoman rule in 1878. The website notes that Christians believe that there had been a monastery at the site before the Muslims came and turned the monastery into a Dervish lodge/tekke, a claim made of many other tekkes in the Balkans and Anatolia. The website, which is in English as well as Bulgarian, is thus more reserved than the Bulgarian-speaking museum employee whom we met in 2008, who presented the site as the tomb of the Christian, St. Atanas, telling the story related above.

In terms of the balance between the religious communities, in this part of Bulgaria Muslims have almost vanished, and the site is increasingly visited by Orthodox Christians, not only Bulgarian but also Russian and Romanian (whose border is only about forty kilometers distant). In May 2009, a "folklore fair-St. Anasthasius" was held at the site for the first time. ${ }^{5}$ The site thus seems to be at a stage of transformation that is likely to turn it into a predominantly Christian shrine, just as Hasluck's model, and ours, would predict. We note that this transformation is taking place in the context of a democratic Bulgaria, a member of the 
European Union and, thus, presumably dedicated to minority rights, comprehensive religious freedoms, and cultural preservation. The museum is facilitating this change.

Other cases of intersecting religoscapes have been presented by perhaps the most persistent critic of the AT model, Glenn Bowman. He and other scholars have done an excellent job of providing detailed ethnography, including a short book with a separate analysis of certain shrines along with professional photographs (Koneska and Jankuloski 2009) and accompanying film (Koneska 2009). Those correspond to and document further sites in Macedonia that Bowman has presented in several publications (Bowman 2010, 2012b) and as the cover photograph of an edited book (Bowman 2012). We focus on the Sveti Nikola church in Makedonski Brod, Macedonia, which "contains the turbe (tomb) of a Bektashi saint, Hadir Bābā," and which is visited by members of other Sufi orders as well as by Sunni Muslims. The Christians also hold rituals there. The place shows very interesting forms of syncretism: various pictures show Muslims praying and, in the background, there are icons of Orthodox Christian saints, and another icon of an Orthodox saint is on the very grave of the Bektashi saint to which they are praying. The flat stone marking the grave, covered by a green cloth, is used by the Christians as a table for their icon and offerings during their rituals. Several striking photographs in the Koneska and Jankuloski volume show Bektashi and Helveti Muslims praying (separately) toward the grave, which has on top of it an Orthodox icon of St. George. Bowman also notes that a Sufi prayed towards the iconostasis that the Orthodox added to the building, thus towards the Christian altar, rather than toward the grave of the saint.

Bowman interprets all of this as a form of "mixing" that is actually a symbiotic "sharing" (Bowman's quotes) of the shrine (Bowman 2010: 202), and reflects "an institutional and personal openness on the part of Orthodox caretakers towards the presence of Muslim 'others"' (Bowman 2010: 203). However, this ignores the main factor of the AT model: dominance. We have argued that when one group is clearly dominant over another, the subordinated group may be permitted to attend the shrines of the dominant group. This fits perfectly the site of the St. Nicholas church in Makedonski Brod: the population of the town is now almost completely Orthodox Christian, so dominance of that group is not threatened, and the building is clearly controlled by the Christians. They determine when the Muslims can utilize the place, and the appropriation of the stone covering the grave of the Bektashi saint to serve as a table for Christian services, even when the Muslims are conducting their own rituals, is a striking manifestation of dominance. Furthermore, de- 
spite the presence of elements of each others' iconography in the building, there is no evidence that the Muslims regard themselves as anything other than, severally, Bektashi, Halveti, and Sunni Muslims, nor are the Christians in doubt as to their identity as Macedonian Orthodox Christians; none of these identities is in question, and neither are they in any way mixed, shared, or mingled. Koneska's essay (2009) and film make these separations literally visible, especially in the original, Macedonian, version of the bilingual text, and in the spoken Macedonian heard in the film.

The importance of both the trajectory of events and the scale of relevant religioscapes can be seen by revisiting Bowman's citation of Hasluck for the proposition that Orthodox Christians rarely if indeed ever convert mosques into churches unless the site had previously been a church (Bowman 2010: 217n13). Hasluck did his fieldwork before World War I, while the Ottoman Empire was still in existence. After final Bulgarian independence in 1908, and the expulsion of the Ottoman Empire from Macedonia in 1912, Orthodox Christians did indeed convert some mosques into churches, including those in Sofia and Uzundzhovo Bulgaria (Hayden et al. 2011). Heath Lowry (2009: 61-93) describes several more such transformations in northern Greece, and notes that this process is understudied. The trajectory of events following the demise of the Ottoman Empire changed the possibilities for contesting dominance between Christians and Muslims, and this change in possibility had local effects but on a large scale. Hasluck's early twentieth-century ethnography thus reflected the structure of dominance of Muslims over Christians in the late Ottoman period but not those in post-Ottoman space, and cannot be taken as evidence of an Orthodox Christian aversion to converting Muslim shrines.

What we find most lacking in ethnographic accounts of interaction that seems non-conflictual is serious consideration of the trajectories of events that set up the systems of dominance that, in our model, allow for such peaceful situations. We believe that the more fully developed approach to competitive sharing put forth in this article should serve to clarify that both long periods of peaceful interaction as well as brief ones of violence can be explained by the AT model, which identifies the conditions that promote both.

\section{Contiguous Religioscapes as Demarcating Borders}

Historical processes may lead to the physical separation of religious communities that had been living intermingled, peacefully through voluntary 
processes of migration, or violently and suddenly through the processes formerly called "population exchanges" and now called "ethnic cleansing." In such cases, what had been nodes in religioscapes may be abandoned, destroyed, or transformed into nodes in the religioscape of the other group. This last form of transformation may be exemplified by the sixteenth-century mosque in Uzhundzhovo, Bulgaria, that since 1908 has been an Orthodox Church (Hayden et al. 2011), or the mid-nineteenth-century Orthodox church in Derinkuyu, Turkey, that since 1949 has been the Republican Mosque (Tanyeri-Erdemir et al. 2014). As for sites abandoned or destroyed, we may recall many Orthodox churches in the Turkish Republic of Northern Cyprus, or many Islamic ones in the Republic of Cyprus; or mosques in the Republika Srpska in Bosnia after 1992, and Serbian Orthodox churches in Kosovo after 1999. In such cases, the religioscapes no longer overlap, and they are unlikely to intersect. They are instead contiguous, marking the frontiers of territories that have been partitioned. The territorial spaces marked by such borders need not be coterminous with state or political borders, though they may become so through time.

We would argue that careful examination of the sites that actually remain in use by members of a minority religious community may reveal aspects of inter-communal interactions that may otherwise go unnoticed. For example, while most people in Belgrade know that there are two türbes in the oldest part of the city, I have observed that these are used as saint shrines by local Muslims, who seek blessings and favor at them. This use is unknown to my colleagues at Belgrade University, even though one türbe is directly across the park from the building that houses the Departments of Anthropology and Archaeology, but it means that the Muslim archaeoscape of Belgrade still has more nodes than might be expected.

Sometimes such a more or less covert use of part of a site that has otherwise been lost to a religious group may indicate that there are more intergroup activities going on than may be recognized at the level of public politics. Two such sites may be seen in northern Cyprus, in places that were major Orthodox Christian sites but from which the Christians were driven away in 1974: the Monastery of St. Barnabus (Famagusta) and the Church of St. Mamas (Morphou). In both cases, the churches were turned into museums. Yet visits to them in October 2011 revealed the renewed presence of Orthodox Christians. ${ }^{6}$ At St. Barnabus, the monastery remains a museum, but the tomb of the saint is lit by votive candles, and has icons and symbolic offerings (dolls representing hoped-for babies, eye symbols for the return of sight) that indicate that the Orthodox faithful, and probably others, are coming there. As for St. 
Mamas, the church looks as though it is ready for a liturgy at any time: the iconostasis is in place, as is the altar behind it, and the altar has all of the necessary equipment. And it turns out that the Bishop of Morphou has been able to hold occasional services in the church, beginning in 2004, thirty years after he and his flock were driven out of the town. It seems that these sites, though officially secularized and thus no longer part of any religioscape, may be serving to make the Orthodox Christian religioscape in Cyprus overlap again with that Muslim one, and possibly even to make them intersect, since Muslims also leave offerings at the shrines to the saints. Mete Hatay has also noted cases of what we would regard as re-overlapping of the Christian and Muslim religioscapes in northern Cyprus, in places where Greek Christian visitors to places from which they or their families had been driven in 1974 are reclaiming parts of abandoned churches by lighting candles in them (Constantinou et al. 2012: 180-82). If we pay careful attention to such low-profile manifestations of religious behavior in places where a group has officially been excluded, we may well be able to see indicators of the low-key sharing of space, even after such sharing has been dissolved at official levels.

\section{Conclusion}

I have utilized the concept of religioscape and the indicators of dominance to analyze the ways that spaces and places were marked as Ottoman and post-Ottoman as manifestations of interaction between Orthodox Christians and Muslims. This analysis demonstrates the importance of linkages between local sites and wider networks of religious structures, at specific moments in time and through time as well. We can thus see the commonalities of the political and social processes that led to the transformation of spaces from Byzantine, thus Christian, to Ottoman, thus Muslim, and in southeastern Europe, from Ottoman to the several Christian nationalist spaces (Bulgarian, Greek, Hungarian, Serbian), on varying scales, and from the seventeenth century in Hungary to the present in Bulgaria. These commonalities indicate that the term "peaceful coexistence" is misleading, as even during periods when there is little or no violence, relations of dominance are manifested in the physical structures associated with religious communities, measured against each other rather than analyzed as isolates, with the divisions reproduced through these structures as well other markers of difference.

From this perspective, looking at local patterns of interaction to explain coexistence is to reverse causality, because it is the placement of a local site on a religioscape, and that site's relationship to the nodes of 
the religioscape of a competing religious community (i.e., contiguous, overlapping, or intersecting), that determines whether local relations are likely to be peaceful or conflictual. Space may be shared as the nodes of competing religioscapes overlap; local shrines may be shared if they form nodes on two or more competing religioscapes; and both larger spaces and local shrines may no longer be shared when the religioscapes no longer intersect. In all cases, however, coexistence must be analyzed through the patterns of competition of the larger religious communities whose religioscapes are represented locally, if we are to understand when it is likely to be peaceful, when conflicted, and when disrupted completely.

Robert Hayden is Professor of Anthropology, Law and Public \& International Affairs at the University of Pittsburgh. While most of his work for the past thirty years has focused on the former Yugoslavia and the Balkans, he has also done substantial research and writing in and on India. Since the 1990s much of his work has focused on the cultural logic of ethno-national violence. His current major project is an international, interdisciplinary, and comparative study on competitive sharing of religious sites that examines the thesis of "Antagonistic Tolerance." He is the author of Social Courts in Theory and Practice: Yugoslav Workers' Courts in Comparative Perspective (Philadelphia: University of Pennsylvania Press, 1990); Disputes and Arguments in a Nomad Caste Council (Delhi: Oxford University Press, 1999); and Blueprints for a House Divided: The Constitutional Logic of the Yugoslav Conflicts (Ann Arbor: University of Michigan Press, 1999), among other works.

\section{Notes}

Research reported here was supported in part by the National Science Foundation, which is not responsible for the views expressed in this paper. I am grateful to Professors Simeon Evstatiev and Galina Stefanova-Evstatieva for their organization of fieldwork in Bulgaria in 2008 and help during it, to Dr. Hande Sözer for her assistance as well during part of that fieldwork and for her comments on this paper, and to Dr. Rabia Harmanşah for her assistance in site visits in $\mathrm{Cy}$ prus in 2011. As with all other work stemming from the Antagonistic Tolerance project, this paper has benefitted from the discussions of my team members: Tuğba Tanyeri-Erdemir, Aykan Erdemir, Tim Walker, Devika Rangacahri, Manuel Aguilar, Enrique Lopez-Hurado, and Milica Bakić-Hayden.

1. Our use of centrality is different from that of Ron Hassner (2009), who instead defines centrality of a site in terms of its "space in the spiritual landscape" of the religious community concerned. He sees conflict as increasing insofar as a site central to a religious community becomes vulnerable to 
being controlled by another community. However, he then confounds the importance of this supposedly primary consideration by noting the importance of vulnerability, saying that conflict should be "expected to arise" at the places a religious group are "most central and most vulnerable," without distinguishing which condition is more important, except to say that he is offering a "rough heuristic at best," and furthermore, that even a minor site can be the focus of conflict "if a local community places high value on it for political reasons" (Hassner 2009: 33). That last admission actually vitiates Hassner's attempt to define centrality in terms of the wider symbolic geography of a religious community and brings it precisely to those local levels where conflict does, in fact, take place. We are confident that our definition of centrality, in terms of the local importance of a site, is thus superior to Hassner's, even in his own terms.

2. By far the best scholarly source on this mosque that I have found is the web blog of Grigor Boykov (2009), which draws on Turkish, Bulgarian, and English-language sources.

3. See the Museum's "gallery" website, http://www.museumbalchik.com/eg/ t_gallery.php?id=\&page $=1$.

4. http://www.museumbalchik.com/eg/mteketo.php.

5. http://www.museumbalchik.com/eg/t_fsabor.php.

6. I am grateful to Rabia Harmanşah for taking me to both sites, discussing their meaning with me and sharing some of her own fieldwork data on them; her dissertation (Harmanşah 2014) contains other details.

\section{References}

Albera, Dionigi. 2012. "Conclusion: Crossing the Frontiers betweeen the Monotheistic Religions: An Anthropological Approach." In Sharing Sacred Spaces in the Mediterranean, ed. D. Albera and M. Couroucli, 219-44. Bloomington: Indiana Univeristy Press.

Albera, Dionigi, and Maria Couroucli, eds. 2012. Sharing Sacred Spaces in the Mediterranean: Christians, Muslims and Jews at Shrines and Sanctuaries. Bloomington: Indiana University Press.

Alcock, Susan E. 2001. "The Reconfiguration of Memory in the Eastern Roman Empire." In In Empires: Perspectives from Archaeology and History, ed. S.E. Alcock, T.N. D’Altroy, K.D. Morrison, and C.M. Sinopoli, 323-50. Cambridge: Cambridge University Press.

- 2002. Archaeologies of the Greek Past: Landscapes, Monuments and Memories. Cambridge: Cambridge University Press.

Appadurai, Arjun. 1996. Modernity at Large: Cultural Dimensions of Globalization. Minneapolis: University of Minnesota Press.

Bachmann, Bálint, and Zoltán Bachman. 2010. "St Bartholomew's Bell Tower." Pollack Periodica 5(3): 19-26.

Baumgarten, Elisheva. 2008. “'A Separate People'? Some Directions for Com- 
parative Work on Medieval Women." Journal of Medieval History 34(2): 212-28.

Birge, Darice. 1994. “Tress in the Landscape of Pausinias's Periegesis." In Placing the Gods: Sanctuaries and Sacred Space in Ancient Greece, ed. S.E. Alcock and R. Osborne, 231-45. Oxford: Clarendon Press.

Bowman, Glenn. 2010. "Orthodox-Muslim Interactions at 'Mixed Shrines' in Macedonia." In Eastern Christians in Anthropological Perspective (The Anthropology of Christianity), ed. C. Hann and H. Goltz, 163-83. Berkeley: University of California Press.

- 2011. “'In Dubious Battle on the Plains of Heav'n': The Politics of Possession in Jerusalem's Holy Sepulchre." History and Anthropology 22: 371-99.

— ed. 2012 Sharing the Sacra: The Politics and Pragmatics of Intercommunal Relations around Holy Places. Oxford: Berghahn Books.

— 2012b. "Identification and Identity Formations around Shared Shrines in West Bank Palestine and Western Macedonia." In Sharing Sacred Spaces in the Mediterranean, D. Albera and M. Couroucli, 10-28. Bloomington: Indiana University Press..

Boykov, Grigor. 2009. "Plodiv (Filibe)." In Ottoman Architectural Heritage in Bulgaria, http://www.oahb.org/category/plovdiv-ott-filibe/ (online resource). Accessed Nov. 12, 2012.

Brubaker, Rogers. 2004. Ethnicity without Groups. Cambridge, MA: Harvard University Press.

Çağaptay, Suna. 2011. "Prousa/Bursa, a City within the City: Chorography, Conversion and Choreography." Byzantine E Modern Greek Studies 35(1): 45-69.

Catlos, Brian. 2014. "Is It 'Country Air' that Makes Infidels Free? Religious Diversity in the Non-Urban Environment of the Medieval Crown of Aragon and Beyond." In La cohabitation religieuse dans les villes Européennes, XeXVe siècles/ Religious cohabitation in European towns (10th-15th centuries), ed. J. Tolan and S. Boissollier, 141-66. Turnhout: Brepols

Constantinou, Costas M., Olga Demetriou, and Mete Hatay. 2012. "Conflicts and Uses of Cultural Heritage in Cyprus." Journal of Balkan and Near Eastern Studies 14(2): 177-98.

Donia, Robert J. 2006. Sarajevo: A Biography. Ann Arbor: University of Michigan Press.

Dostoğlu, Neslihan, Kensuke Kitagawa, and Yasushi Asami. 2004. "Locational Tendency of Mosques in Bursa, Turkey: Regional Study Using Geographic Information System." Journal of Architectural and Planning Research 21(3): 209-21.

Dumont, Louis. 1980. Homo Hierarchicus: The Caste System and Its Implications (complete revised English edition). Chicago: University of Chicago Press.

Evans, Helen C., and Brandie Ratliff, eds. 2012. Byzantium and Islam: Age of Transition, 7th-9th Century. New York: Metropolitan Museum of Art.

Gradeva, Rossista. 1994. "Ottoman Policy towards Christian Church Buildings." Balkan Studies (Etudes balkaniques) 4: 14-36. 
Green, Monica H. 2008. "Conversing with the Minority: Conversations among Christian, Jewish and Muslim Women in the High Middle Ages." Journal of Medieval History 34(2): 105-18.

Harmanşah, Rabia. 2014. "Performing Social Forgetting in a Post-Conflict Landscape: The Case of Cyprus." Ph.D. dissertation, University of Pittsburgh.

Hayden, Robert M. 2002. "Antagonistic Tolerance: Competitive Sharing of Religious Sites in South Asia and the Balkans." Current Anthropology 43(2): 205-31.

_- 2005. "Religious Structures and Political Dominance in Belgrade." Ethnologia Balkanica 9: 213-24.

Hayden, Robert M., et al. 2011. "The Byzantine Mosque at Trilye: A Processual Analysis of Dominance, Sharing, Transformation and Tolerance." History and Anthropology 22(1): 1-17.

Hayden, Robert M., et al. 2016. Antagonistic Tolerance: Competitive Sharing of Religious Sites and Spaces. London: Routledge.

Hayden, Robert M., and Timothy D. Walker. 2013. "Intersecting Religioscapes: A Comparative Approach to Trajectories of Change, Scale and Competitive Sharing of Religious Spaces." Journal of the American Academy of Religion 81: 399-426.

Henig, David. 2014. "Contested Choreographies of Sacred Spaces in Muslim Bosnia." In Choreographies of Shared Sacred Sites: Religion and Conflict Resolution, ed. E. Barkan and K. Barkey, 130-60. New York: Columbia University Press.

Inalcik, Halil. 1969/70. "The Policy of Mehmet II toward the Greek Population of Istanbul and the Byzantine Buildings of the City." Dumbarton Oaks Papers 23/24: 229-49.

Kiel, Machiel. 1991. "Hrazgrad-Hezargrad-Razgrad: The Vicissitudes of a Turkish Town in Bulgaria. Historical, Demographical and Art Historical Notes." Turcica 31-32: 495-563.

Kitagawa, Kensuke, Yasushi Akami, and Neslihan Dostoglu. 2004. "ThreeDimensional View Analysis Using GIS: The Locational Tendency of Mosques in Bursa, Turkey." In Islamic Area Studies with Geographical Information Systems, ed. O. Atsuyuki, 243-52. London: Routledge Curzon.

Koneska, Elizabeta, dir. 2009. Мир на Cume / Peace for All. Macedonia.

Koneska, Elizabeta, and Robert Jankuloski. 2009. Заеднички Светилишта / Shared Shrines. Skopje: Macedonian Center for Photography.

Lowry, Heath W. 2009. In the Footsteps of the Ottomans: A Search for Sacred Spaces and Architectural Monuments in Northern Greece. Istanbul: Bahçeşehīr University Press.

Lubanska, Magdalena. 2013. "Muslim Pilgrims at the Orthodox Christian Monastery in Hadzhidimovo: Studies on Religious Anti-syncretism in the Western Rhodopes, Bulgaria." Anthropological Journal of European Cultures 22(2): 91-110.

Margos, Ara. N.d. Текето Ак Язъль Баба-Пъте-водител. [The Tekke of Ak Yazul Baba-Guide] Толбухин: Окръжен историчецки музеи Толбухин. 
McAlister, Elizabeth. 2005. "Globalization and the Religious Production of Space." Journal for the Scientific Study of Religion 44(3): 249-55.

Mišković, Nataša. 2011. Базари и Булевари: Свет Живота у Београду 19. Века [Bazaars and boulevards: The world of life in Beograd in the nineteenth century]. Београд: Музеј града Београда.

Necipoğlu, Gülru. 1992. “The Life of an Imperial Monument: Hagia Sophia after Byzantium." In Hagia Sophia from the Age of Justinian to the Present, ed. R. Mark and A. Cakmak, 195-225. Cambridge: Cambridge University Press.

Parveva, Stefka. 2002. "Intercultural Contact and Interaction in the Ottoman Period: The Zaviye Kavak Baba and the Church of the Holy Forty Martyrs in the Real and Imaginery World of Christians and Moslems in the Town of Veliko Tarnovo (15th-19th c.)." Bulgarian Historical Review 2002(1-2): 13-54.

Radcliffe-Brown, A.R. 1965. "On the Concept of Function in Social Science." In Structure and Function in Primitive Society, 178-87. New York: Free Press,.

Rajić, Delfina and Miloš Timotijević. 2011. Црква Светог Вазнесења Христовог у Чачку [The Church of the Holy Assumption of Christ, Čačak]. Чачак: Народни Музеј Чачак.

Robbins, J., and J. Siikala. 2014. "Hierarchy and Hybridity: Toward a Dumontian Approach to Contemporary Cultural Change." Anthropological Theory 14(2): 121-32.

Schama, Simon. 1995. Landscape and Memory. New York: Alfred A. Knopf.

Sözer, Hande. 2012. "Managing (In)Visibility by a Double Minority: Dissimulation and Identity Maintenance among Alevi Bulgaria Turks." Ph.D. dissertation, University of Pittsburgh, Anthropology.

Tanyeri-Erdemir, Tuğba, Robert M. Hayden, and Aykan Erdemir. 2014. "The Iconostasis in the Republican Mosque: Transformed Religious Sites as Artifacts of Interesecting Religioscapes." International Journal of Middle East Studies 46: 489-512.

Taylor, Mark C. 2007. After God. Chicago: University of Chicago Press.

Turner, Bryan S. 2008. "Religion and Politics: Nationalism, Globalisation and Empire." Asian Journal of Social Science 34: 209-24.

Uluengin, Mehmet Bengü. 2010. "Secularizing Anatolia Tick by Tick: Clock Towers in the Ottoman Empire and the Turkish Republic." International Journal of Middle East Studies 42(1): 17-36. 
2. Chapter $3 \cdot 6$

\title{
Cosmopolitanism or Constitutive Violence?
}

\author{
The Creation of "Turkish" Iraklio
}

\section{ARIS ANAGNOSTOPOULOS}

\begin{abstract}
W
hen thinking and speaking of past coexistence, we necessarily speak from the historically specific ideological conditions of contemporary discourses, since those discourses have been shaped by events of fissure and strife. This has become by now almost a truism in the social sciences, but it is far less accepted in public discourses on historical division. When studying peaceful coexistence before a period of interethnic strife, we need to wonder, for example, whether the subjects of this coexistence are social entities created after the fact of violent rupture. This is a point amply made by Rebecca Bryant in the introduction to this volume and need not be reiterated here. What I want to consider, however, is that this condition of reflexivity is not an epistemological adeptness-or lack thereof-on our part, but a historical "real": the very same processes and events that were recorded as transformative in the timeline of communities are often those that create the analytical categories we assume as natural. Historians and social scientists, as evidenced in this volume, speak and intervene as political subjects firmly embedded in an ex post facto arrangement of concepts, people, and things. In this respect, it may be more pertinent to instill a radical strangeness in these taken-for-granted agglomerates, rather than establish a final truth about communities and individuals in the past, which, as Bryant points out, may oftentimes be impossible. By studying these liminal positions of strangeness, we may hope to understand more clearly the construction of either/or binaries through which historical reason functions in intercommunal conflict (see Bakshi this volume), but also establish our position as engaged subjects, without recourse to essential identities and states (Bryant this volume).
\end{abstract}


The particular examples I discuss below show how historical categories such as "Turkocretans," widely accepted today as an accurate sociological denomination for Cretan Muslims and a political tool for reframing interreligious coexistence, when examined more closely present testimonies for a violence of definition that is the corollary of a social rupture they leave unexplained. The profound antagonism between Christian and Muslim Cretans produced a descriptive term for the latter, which bore the marks of the predominance of the former in all aspects of social life during the last half of the nineteenth century (Andriotis 2004). The creation of sociological entities such as "communities" is often intertwined with larger projects of power, which reshape the material environment and therefore alter the memoryscape in which groupings of people are imaginatively created and remembered. The way scholars and laypeople approach and recreate images of peaceful coexistence in the Ottoman Empire is oftentimes markedly aestheticized by the heritage industry of today, especially in the context of cosmopolitan Mediterranean ports, and often prevents them from understanding the context of coexistence in the past (e.g., Ilbert and Yannakakis, 1997; see also Driessen 2005; Waley 2009). Furthermore, a picture of coexistence painted after conflict has occurred may avoid the portrayal of power relations of exploitation or oppression on a multiplicity of levels-gender, class or otherwise-in favor of a major, usually ethnic, antagonism (see Starr this volume; compare Humphrey 2012: 45; Theodossopoulos 2006).

The turn of the twentieth century constituted a threshold in the history of Crete. Following a Christian insurrection that began in 1896, in 1898 the nearly two hundred-year-long Ottoman rule was succeeded by an autonomous regime that lasted for fifteen years, up to 1913, when Crete was officially annexed to Greece. The year 1898 marked, for the inhabitants of the city of Iraklio, the beginning of the destruction of the material traces of Ottoman presence. This was part of a class initiative to reshape the city into a western metropolis (Anagnostopoulos 2007) - a process that began after Iraklio was annexed; gathered pace in the decades following the 1923 exchange of populations, when the last Muslims left the island; was deepened by wartime destruction; and eventually reached its apex in the construction boom of the early 1970s. Throughout the destruction of the Ottoman past of the city runs a uniting thread that connects the annihilation of material artifacts with the effacement of the living memory of its Muslim inhabitants. The latter either abandoned the island in subsequent waves of immigration to Asia Minor and the Middle East, or they were forcibly relocated in the 1923 exchange of populations. The very process that guaranteed the destruction of the marks of their presence was the same process that created the 
grounds for the nostalgia for the "others" that cohabited the cosmopolitan city. In a very apposite irony, this process began effacing the marks of those others by first naming them.

\section{One City, One History, Two Cities, Two Histories, or Perhaps More?}

In 2004, in view of the portion of the Olympic Games being held in the city, the municipality of Iraklio issued a DVD guide to the city in collaboration with the University of Crete. The guide, a celebration of the material and cultural heritage of the city, is called "Heraklion, A City Through the Ages." The Greek subtitle of the guide is much more revealing of its scope: "One City, One History" (mia poli, mia istoria). The unification of the history of the city into one continuous narration, held together by the material fabric of the city and the traditions, real or invented, of the people inhabiting it today, is further pursued in the spoken text, especially in the section "Monuments" (or "Space" in the Greek version):

Through $[s i c]$ a dynamic city, modern Iraklion is steeped in the history of its awe-inspiring defenses. A stronghold built by the sea, its walls stand in silent witness to the moments of glory and terror. Many races have found a home in its streets, and many gods have been invoked in its houses of prayer. Along its winding streets, humble dwellings are cramped cheek-by-jowl with neoclassical mansions and modern, multi-story apartment blocks. (Municipality of Heraklion 2004)

To identify Iraklio with its Venetian ramparts is here a convenient way of conceiving the city as a single, compact body, transformed though history. Many of the "races" implied in the voiceover lived in the city long before the "awe-inspiring defenses" were constructed in the fifteenth century CE. The idea of the enclosed city-organism is the converging point for the rationales of modern heritage industry and nationalist history: past antagonisms and historical transformations are subsumed into a major antagonism, which in this case is understood as the liberation of Cretans-Greeks-from subsequent waves of invasion and occupation, which is inscribed in the unified material infrastructure of the city and sold as a packaged commodity to the thousands of tourist visitors each year. In view of this subsumation, material markers of communal or other identity that were prominent in the past are naturalized as marks of the "pluralism" of the cultural heritage of the city. The different "races" that walked the streets of the city, the different religions that prayed 
in its confines, and the different classes and gendered individuals that lived in the city, are all transformed into positive forces that "secreted" the multifarious built record of the city, which proves a selling point in the context of the heritage industry today. Ironically, the effort to show the city as a unique transhistorical organism is a distinctively modern concept. The Cretan Autonomy period (1898-1913) was marked by the effort of the prevailing Christian Cretans to modernize the city according to Western precepts (Anagnostopoulos 2007). City authorities and entrepreneurs cut into the fabric of the city, excising most signs of heterodox presence-especially Muslim. ${ }^{2}$ For example, there is not a single standing minaret in Iraklio, whereas the minarets of the other main cities of Crete (Chania and Rethimno) constitute iconic selling points for these cities. Much later, during the commercial and tourist boom of the 1960s and 1970s, important Venetian landmarks-such as the church of St. Salvador-were demolished by the city authorities following decisions to encourage progress aimed at creating a cityscape more akin to a western metropolis. The idea was to open up spaces and roads in the urban fabric that to many progress-minded commentators looked like a "tourkopolis" (Turkish city) (Dermitzakis 1963: 89). Now this dedication to progress has put Iraklio in the difficult situation of having to shape a past by pulling together what remains of the destructive effects of modernization (Anagnostopoulos 2007, 2011).

In the DVD, the Muslims of Crete are rarely encountered. In fact, they are only mentioned as the mob that perpetuated the uprising of 25 August 1898 and the slaughter of some two hundred Christian Irakliots and eighteen British soldiers (Karelis 2001). However, many of the old houses that are presented as the built heritage of the city are Muslim Cre$\tan$ houses. In fact, throughout the nineteenth century at least, Cretan cities were predominately Muslim. Iraklio itself had a very pronounced Muslim element, which declined after the transition to the autonomous regime in 1898 and the massive immigration of Cretan Muslims. ${ }^{3}$ Irakliot Muslims were notorious for their propensity to mass violence; however, there is little known about the social reasons for the reactions of the most destitute of Iraklio Muslims (see Anagnostopoulos 2007: 88; Andriotis 2004: 71). This "barbarous mob" featuring in most histories of Crete and the city is responsible however for most of the remaining buildings that constitute the "old Iraklio" today.

The periodization of Cretan history presented in the DVD is based on the tacit understanding that the history of Crete is the history of its conquest by foreign armies, and that the time between the Byzantine era and 1898 was merely a break in the continuation of Greek history on the island. To give only one example, the nineteenth century, a century of 
profound changes in the administration and character of the Ottoman Empire (Ortayli 1999), which had equally deep and long-lasting effects on the social formations in Crete, is described in the work of historians of Crete as "the era of Cretan revolutions" (e.g., Detorakis 2005: 26). International events feature in this kind of history only as a backdrop, as echoes from distant shores, but Cretan history is conceived as a product of the voluntarism of its people and their desire for union with Greece. The dramatic and epic scale such events are described in this history contrasts starkly with the parochial character historians attribute to it, since they consistently refuse to examine Crete as part of a wider network of economic exchanges and political power. Consequently, all interpersonal, familial, or clan instances of violence recorded throughout the nineteenth century are inscribed into this narrative of the struggle of all (Christian) Cretans for unification with Greece.

While this picture is currently being rectified in economic history (e.g., Perakis 2008), social history remains trapped in a strange conundrum. Contemporary historians attempt to counter strictly nationalist narratives by emphasizing the cosmopolitan past of the city. Giannis Zaimakis, for example, in a chapter titled "The Cosmopolitan City, 19001923," after stating that "historical events and political changes transformed the social body of the 'oriental' city" (Zaimakis 1999: 69), gives the following description:

Cultural elements of the spatial organization, like religious monu-
ments (Orthodox, Sinai and Armenian temples, mosques, minarets
and tekkes), Venetian buildings (the Koule, ${ }^{\text {t }}$ the Loggia, the tall ram-
parts etc), the Arabian wall, poor neighbourhoods with stone paved
alleys and low-ceilinged houses, mondain ['kosmikos'] squares with
theatre halls and nightclubs and, finally, scattered cafe aman and cafe
chantants shaped a landscape that testified to the cosmopolitan char-
acter of the city and the mix, in its environment, of various cultural
traditions. (Zaimakis 1999: 70)

The question here, of course, is how in the two years that followed the end of Ottoman rule the city was transformed from "oriental" to "cosmopolitan." On further examination, the question remains: what exactly is the difference between the two cities, since the picture Zaimakis gives us can apply to the city at the end of the nineteenth century as well as at the beginning of the twentieth (see Zei 2005: 82). The answer, according to the same author, is that the violent antagonism of the two main religious elements brought about profound demographic changes, with the emigration of some 40,000 to 50,000 "Turkocretans" to Asia Minor and 
North Africa. It thus transformed a predominantly Muslim city into a city where the two elements were almost equally represented, with the Muslim element constantly declining until their final departure during the population exchange following the Asia Minor defeat of the Greek army in 1923. At the same time, the British occupation of the city, the development of trans-local communication networks and the mingling of different ethnicities within the city "created conditions of cosmopolitanism" (Zaimakis 1999: 70).

One could counter that trans-local communication networks were already in place by at least the beginning of the eighteenth century (Triantafillidou-Balladié 1988), while contact with foreign ideas and mores was a mainstay for the wealthier classes of the city at least since the middle of the nineteenth century (Svolopoulos 2005: 147). Besides that, the main import of this description is to contrast cosmopolitanism to the "oriental" city. In a few words, cosmopolitanism is secured only after the ethnic (religious) balance is shifted, when the Turkocretans leave the island, and only when the legitimate use of force (to use a Weberian category) changes hands and comes to employ distinctively Western techniques of liberal governance (Svolopoulos 2005: 122-23; compare Foucault 1997: 73-74). Up to then the Ottoman Empire was the guarantor of the health and prosperity of the Muslim element. Now, the Great Powers were the guarantors of the growing economic and social power of the Christian element, and the legitimacy of the new autonomous state. The predominance of the Muslim element was prohibitive of cosmopolitanism, but contributed greatly to it through its minority existence after its gradual uprooting from Crete. Its non-presence, and the marks that it leaves behind, become cultural markers that secure the character of the new, cosmopolitan city. In fact, the cosmopolitan city becomes cosmopolitan only when contrasted to the older, "oriental" city, and incorporates the material fabric of this city as an indicator of this passage to modernity (compare Said 1978: 6-7).

Cosmopolitan versions of the city's past are strikingly similar to what Renato Rosaldo has termed "imperialist nostalgia": the agents of ruination feel nostalgic toward the state of things they have destroyed. The very force of destruction is the one that produces its memory, but occludes the process of destruction itself (Rosaldo 1989). Central to the "crypto colonialism" (Herzfeld 2002) of the West in this case is the activity of merchant elites, especially Christian ones, in the forging of a cosmopolitan identity for the city. In fact, as recent work on "actually existing cosmopolitanism" (Robbins 1998: 2) shows, cosmopolitanism is an explicitly class-bound "ethos" that is intrinsic to the activity of mercantile elites who integrated the eastern Mediterranean into the world 
economy (Driessen 2005; Sifneos 2005). The ways in which this class ethos and its related ethnic politics translated into an aesthetic outlook of nostalgic cosmopolitanism is well documented for other port cities, as for example for Habsburg Trieste (e.g., Ballinger 2003a, 2003b; Waley 2009). The paradoxical nature of nostalgic claims to Irakliot cosmopolitanism is that it runs counter to wider political understandings of cosmopolitanism. Recent revisions of the notion have stressed that cosmopolitanismas a political program envisioned in the early nineteenth century-is inimical to the territorial demands of the nation-state, although it can be a compliment to nationalism and irredentism (Cheah 1998: 25; see also Fine 2003, 2006). In the case of Crete, cosmopolitanism in its port cities was enhanced, rather than inhibited, by the protection of the millet system (compare Driessen 2005: 138), and flourished in tandem with the irredentism and nationalism of its Christian inhabitants. As Ballinger shows in the case of Trieste (Ballinger 2003b: 93), the apparent paradox of Cretan irredentism coinciding with cosmopolitanism is no paradox at all, in fact it is part of the political action that created a network of contacts and power that caused political and social change. What is really paradoxical is that this cosmopolitanism is attributed to its effect, rather than its cause: that it was really produced by the coming of the territorial state-which was the end result of its political mobilization - rather than the social relationships of empire that produced and nourished it.

The construction of the historical entity of the "old Iraklio" (to palio Iraklio), which represents the city at an indeterminate point in time amounts to a project of "aesthetic cosmopolitanism" (Kofman 2005; Calhoun 2008), stripped of its social or political corollaries and presented as a characteristic of the city-organism rather than a trait of a specific class. It selectively connects a Eurocentric vision of modernity to a fetishization of ruins in the promotion of the European character of the city: the unifying characteristic is not the haphazard, maze-like urban fabric of "oriental" times, but the sturdy, imposing ramparts of Venetian, i.e., European, tradition. The erasure of poor, disenfranchised, oriental subjectivities from the shaping of history, through a variety of means, described below, is therefore the other central characteristic of this aesthetic. The remains of this underrepresented element constitute an addendum to aesthetic cosmopolitanism: without these remains, a cosmopolitan image is impossible.

\section{Marks of Coexistence and Invisible Minorities}

Invisible and unrepresented, the Muslim element is usually identified with the anonymous mass that produced the indiscriminate maze of 
low-rise houses in the poorest neighborhoods of the city. This maze in its nostalgic content becomes in other narratives a symbol of something else entirely: the peaceful coexistence of the "common people," who in fact had nothing to divide them and were living in a continuous peace that was wracked by the forces of politics (compare Millas 2006). Interestingly, accounts of this sort were descriptions of the Muslim element after the predominance of the Christian, in the two decades or so between the regime change of 1898 and the forced repatriation of Cretan Muslims in 1923.

Elli Alexiou, a female, left-wing writer, disciple and friend of Kazantzakis, wrote an autobiographical short story (published in 1938), in which this association of built monuments in space is precisely tallied with the forced excision of Muslim Cretans from the past of the city and the island, leaving only their material traces behind. The short story begins with the communal spring donated by one "Brahim Baba," which was the mainstay of the neighborhood and a common source for water. It was built by Ibrahim Baba, still alive at the time of Alexiou's writing, as a donation for his son's well-being. Alexiou describes it as a communal monument, a place for socialization, and also a marker for very personal coming-of-age rituals. The story then recounts the forced expatriation of Muslims and how their Christian friends reacted with sadness and a true sense of loss. Exhorted by her friend Hayriye Hanım, Ibrahim Baba's wife, Alexiou's mother sends the then teenage writer to tend the grave of Hayriye's unfortunate son, to whose health the spring was donated. The story ends with Alexiou and her brother encountering two civil engineers taking measurements of the Muslim cemetery for the refugee encampment subsequently built on the grounds: "The foundations of the houses were built on skulls and all sorts of human remains" (Alexiou 1978: 73). To Hayriye Hanım's constant questions in letters of whether the hyacinths on her son's grave were in bloom, Alexiou's mother falsely replies "yes, indeed they are again this year" (Alexiou 1978: 73).

While, in a sense, accounts such as these aim to subvert the nationalist narrative of predating Turks by showing the plight of Cretan Muslims, they nevertheless accept the major antagonism central in these accounts as valid. They accept, in other words, that the cultural differences between Christians and Muslims were the only real differences worth considering. Other, less politically discerning writers, offer a much more nuanced picture. For example Marika Freri, born in 1907, describes the neighborhood where she grew up in the only Christian house, not as an "ethnic," undifferentiated social space, marked by the idiosyncrasies of Cretan Muslims, but as a space where other differences, and particularly class differences, were also active. She explicitly contrasts the wealth of 
Fatima, wife of the rich landowner Sami Bey, with the destitution of her fellow Muslims who lived in miserable abodes at the edge of the neighborhood (Freri 1979: 36-40).

The extent, however, to which the prevailing narrative about Cretan Muslims blinded social commentators and memoirists to the difference and variety crisscrossing Irakliot society at the time, is equally evident in discerning accounts of urban life. Manolis Dermitzakis, for example, a local barber, poet, and memoirist tends to lump all together as "Turks" Turkish officers; wealthy Muslims, educated in the ways of Islam; and the lower Muslim strata (Dermitzakis 1962). Furthermore, while women writers, such as Freri or Alexiou, stress cultural differences as elements of difference but not antagonism, their male counterparts reminisce somewhat differently, by coupling stories of coexistence with more polemic accounts; a good example of the latter is Kazantzakis's account of the city in Kapetan Michalis (Bien 2001). Both men and women writers, however, represent women as guarantors of peaceful coexistence in the city, due to their mild character and female charms (see Anagnostopoulos 2014). Kondylakis, for example, in a series of articles that I will analyze below, notes with evident nostalgia: "Poor Hanıms! If it was up to most of them, there would be such concord between Turks and Christians! They are especially conciliatory, and their beauty is often so great that it softens the cruelest heart" (Kondylakis 1896b). This is an oblique recognition of the communal ethos that emerged from practical considerations of everyday coexistence, of communal organization on the ground. Christians and Muslims shared common ground and habits, especially in the markets of the city, but also a deep-seated antagonism, which translated much larger stories of national strife into everyday terms (Dermitzakis 1962; Vardavas 1971a). It is therefore significant that stories of coexistence are woven into narratives that involve women as active agents and take place in essentially "effeminized" urban public spaces, such as communal springs (Anagnostopoulos 2011).

The Muslim element was doubly erased from the memory of the city. In nationalist versions, all Muslims are presented as the demonic "other," the instrument of the oppressing "Turkish" regime, against whom Christians (Greeks) rose in revolt, rightly ousting them from the island. On the other hand, the contribution of this element to the built fabric of the city is cleansed of any reference to ethnic or religious denominations as active agents, and presented as the result of a regime of "coexistence." These twin versions present us with the same conundrum: either the Muslims of Crete were violent barbarians or they were peaceful nonentities. Their violence is either vile or nonexistent, but in any case it has no social roots at all. 
The Muslims of Crete as a historical entity are a mute subject as well as a construction of historical thinking. Others speak about them; their speech is mediated by the reminiscences of their Christian compatriots or the appreciation of the authorities for their humble abodes. There are rare occasions where a distinctively Muslim "voice" can be heard (e.g., Planakis 2011; Anagnostopoulos 2011). Appropriately, a recent investigation into the Muslims of Crete by a social historian was called "Turcocretes: In Search of Identity" (Tzedaki-Apostolaki 2001). Yet, the search for identity that is more evident right now is that conducted by the historians themselves. The existence of Cretan Muslims constitutes a major historiographic problem, that of writing about a group of people that has left sparse representations of itself as a community of any kind (see, e.g., Andriotis 2004; Peponakis 1997). However, in their attempt to resolve the question of political violence, social historians reverted to a notion that is totally created by the Christians of Crete, namely the Turkocretan.

The problem, then, is not whether the Muslims of Crete were violent or not. The problem is the question itself, which presupposes that the Muslims of Crete were one thing that must be examined in its totality as a political entity; that their violence, collective or individual, must be explained accordingly, based on social, cultural, or, even worse, "racial" traits. That violence, especially ethnic violence, is central in the political constitution of this entity is evident. However, this violence is much different than the one supposed by the historians. Historians attempt a sum totaling of acts of violence under the common denominator of ethnicity-religion. For example, Margaritis states that the massacres perpetuated by the Muslims in Iraklio were of lesser impact and scale to the massacres perpetuated by Christians in Sitia (Margaritis 2001: 104). It is unclear whether the Muslims of Iraklio had anything in common with the Muslims in Sitia, and the same goes for the Christians of the same regions. In fact, fractionalism was much more pronounced in the two purported camps than is commonly accepted (e.g., Aggelakis 2004). Losses on two "sides" presuppose that there are two sides that understand themselves as such. Not only as enemies of one another, but also as friends, as culturally common within their confines. The notion of the millet may have been an official way of thinking, but it is unclear to what extent it unified the religious element on the ground, beyond a merely strategic identification with a religious creed that regulated access to state services. As has been noted, the imagination of the antagonistic other is paramount in the transgression of these fractional differences within the community and sometimes the constitution of a nation-in-waiting from people who would not think of themselves as 
members of a community (Bowman 2003, 2007). In this case, it also constitutes the Other as a distinct community, through a process that misrepresents this Other, effaces the social grounds of its existence and leaves traces that become ex post facto histories of this imagined Other.

\section{Naming the Other}

The category "Turkocretes" (Turkish Cretans) used by modern-day historians to denote and analyze Cretan Muslims as a community, as a consistent ethnicity, has a revealing genealogy. As a descriptive term, it collapses regional and class variations, and proposes a common identity, which probably only gained some significance after the last of the Muslims had left the island for the Asia Minor and North African coasts in 1923. Then it came to signify Greek-speaking, Muslim refugees from Crete. The first public appearance of the term in writing that I have located is in an article by the popular fiction writer and journalist Ioannis Kondylakis in the Athens daily Estia, on 15 June 1896. While it is certain that Kondylakis did not himself invent the term, he is probably responsible for turning it into a sociological category of invented ethnicity. Kondylakis aimed to show that Cretan Muslims were in their majority Cretans who were converted to Islam after the Ottoman occupation of Crete in 1669 (see also Peponakis 1997). The new converts, albeit forced to change their religion, were so eager to show their allegiance that they were gradually transformed into "the fiercest and most reprobate of Turks" (Kondylakis 1896a). He recognizes that this accusation is not valid for the entire Muslim population of Crete, stating that the Muslims of the Iraklio rural provinces are more tame and industrious (Kondylakis 1896b), or that the differences in customs and appearance between Christians and Muslims are minor and attributable to religion: "Their life in general differs from the mores of Christians only where it is connected with their religion or soiled [sic] by Turkish wickedness" (Kondylakis 1896b). He nevertheless attempts to give an account of differences that constitute the Muslims of Crete as a distinct ethnic group, and furthermore, one responsible for the perpetuation of the violence of the Ottoman state against its subjects.

But why did Kondylakis seek to introduce this new term at the time for the Athenian reading public? He could simply refer to Cretan Muslims, as foreign diplomats, politicians, and the international press called them, and at least some of the Cretan Muslims called themselves this at the time (e.g., Députation des Musulmans de Crête 1896). Kondylakis was writing amid an uprising by the Christian element of Crete that was 
meant to be the last under Ottoman rule. The nationalist atmosphere in Greece, which would lead to the unfortunate Greek-Turkish war of 1897, brought the "Cretan Question" to center stage once more, as a pivot to the populist nationalism of different political factions in Athens (Gianoulopoulos 2001: 132). Simultaneously, the time seemed ripe for the annexation of Crete, either through diplomatic means or through direct intervention of the Greek army (see Holland and Markides 2006: 87).

While the violent transition from Ottoman rule to autonomous state took place, other political questions emerged, regarding the status of Cretan Muslims in a new territorial state, whether autonomous or annexed to Greece. This debate took place in view of massive Muslim outmigration from Crete. Muslim smallholders sold off their property, pressed by the Christian insurgents in the countryside, and left the island permanently (Andriotis 2004: 88; Margaritis 2001). The emerging regime was forced to guarantee equal treatment to prevent further out-migration and depletion of the island's productive workforce (Svolopoulos 2005: 111). The equality of the two creeds was guaranteed in the new constitution of the autonomous regime by the notion of ithagenia (autochthony), which employed the ideological notion of the Cretan soil as a basis for an ad hoc Cretan ethnicity, which transversed "older" religious differences and securely tied ethnic identity to the territory of the new state (Anagnostopoulos 2007: 177). Simultaneously, however, an official discourse was necessary that would account for interethnic violence, an analysis that would simultaneously advance the irredentist cause of Cretan Christians to its final consummation at enosis (union) with Greece, and pave the way to peaceful coexistence afterwards. The attention of social commentators turned to the "Turkocretans," as a slippery category denoting every Cretan Muslim by referring to the most fanatic among them. By naming this social group, it created it. At the same time, however, it concealed the social sources of events of religious fanaticism, and especially the ever-increasing numbers of Muslim Cretans who were violently pushed into poverty in contrast to the rising fortunes of their Christian compatriots (Andriotis 2004: 87-90).

Kondylakis's first use of the term is already loaded: the apparent confusion that ensued from a term that aimed to denote ethnicity in the context of religious affiliation in the millet system shows how the political position of Kondylakis determined its content, but also allowed for other meanings to slip in. This is evident for example in the brochure "Turkokrites" written by the translator and specialist in Ottoman law Konstantinos Fournarakis in 1929 (Fournarakis 1929). Fournarakis manages to use the term Turkocretes only a handful of times, preferring the 
more descriptive Cretan Muslim instead, pointing to the fact that ethnic identity and religious conviction were situation-bound and contingent, rather than ascriptive, especially in view of the devolution of the millet system and the empire as a political formation. He seems to reserve the characterization for those Cretan Muslims who were better off and had closer ties with the Ottoman administration, the urban and rural aghas and beys, wealthy enough to afford harems and konaks (Fournarakis 1929: 9). The marked class differences within the Muslim population, and its class relations with the Christian element, are already discernible in Kondylakis's account several decades earlier, as well as other contemporary accounts as we have seen above.

Fournarakis was writing six years after the last of the Muslim Cretans were forcefully transferred to the Asia Minor coast, as a result of the "population exchange" agreed to in the Lausanne Treaty. Therefore the author was referring to a social category that was already in the past, and its manipulation into nostalgia could be safely completed. To this day, the term has been so profoundly consolidated to signify Muslim Cretans in general, that scholarly debate can talk about "Turkocretans" as if they were a "really existing" ethnicity even before the events of their violent excision from the island (e.g., Tzedaki-Apostolaki 2001). As Slavoj Žižek argues, the identity of an object is "the retroactive effect of naming itself: it is the name itself, the signifier, which supports the identity of an object" (1989: 95, emphasis in the original). Indeed, the creation of a name marked the precise moment of the beginning of the excision of this population from the life of the island, and in particular the economic and social life of the city. To look for the missing identity of "Turkocretans" without looking at the genealogy of the term itself, is an incomplete undertaking, and furthermore one that embodies a profound symbolic violence. The very category that is aimed at bringing to light a supposedly forgotten "ethnicity" forgets the conditions of the creation of this category.

\section{Spatial Politics: The "Oriental" City Versus the "Modern Western" Metropolis}

As Thomas Hansen points out, "[t]he question of naming revolves," among questions of history and language, "around the question of which space, and whose, should the name fix and territorialize as its object" (Hansen 2001: 3). A bundle of interconnected processes were at work in this erasure, all of which had to do with novel techniques and ideologies of managing space in the city. In Crete, and especially in the cities, the 
creation of "Turkocretans" went hand in hand with the political project of restructuring urban space. The Christian bourgeoisie, who had consolidated their control over the political fortunes of the cities, developed a discourse of progress from the filthy and disorganized Ottoman city to the controllable, clean and ordered Western, cosmopolitan metropolis, that put the blame for the destitute condition of the city in the aftermath of the 1896 uprising on the cultural shortcomings of the Muslim element.

The image of the city when a British garrison was stationed there in 1897 was nearly apocalyptic. Almost 50,000 destitute, impoverished and hungry Muslim refugees were lumped within the city walls, when in times of peace the city had a mere 20,000 inhabitants (Detorakis 2001: 112). The sanitation officials of the British occupying army described the situation with alarm in their reports to the Foreign Office. In those papers, written by Lieutenant Clarke (sanitation officer for the British garrison in Iraklio, and later advisor for public health with the Cretan government), was a report copied verbatim from his correspondence with Amabile Ittar, a doctor of Italian descent, member of the "good society" of Christian Irakliots. Ittar accounts for the sorry state of the city by giving a description of the island's Muslims, saying that while for "Orthodox" Muslims in general bodily hygiene is of major importance, for the rural Muslims, because they are of the Bektashi order and therefore more secular, ablutions are not the norm, so they are "still less apt to feel horror of filth and dirt" (Turkey No. 1 (1899): Further Correspondence: 130). The medical gaze of the two correspondents was informed by the already established practices of the European urban sanitation movement. But their ideological proximity was not based on a community of interest: Clarke's concerns were practical, as he wanted to sanitize the eastern neighborhoods of the city, packed to capacity by impoverished Muslim refugees. These neighborhoods were a potential source of contagion, and were close to the ramparts where the British garrison was stationed (Anagnostopoulos 2007: 114-16). For Ittar, cleaning these neighborhoods was part of a much larger scheme. On the one hand, his alarm was not only of a sanitary nature, but of a moral one as well. These neighborhoods were locally known as berbat mahalle-and sanctioned most of the city's unsolicited brothels and makeshift taverns. ${ }^{5}$ These neighborhoods were thus seen as sources of pollution on two fronts.

Ittar was a vocal spokesman for the developing scheme of urban reform that was brought forward by the most enterprising of the city's bourgeoisie. Sanitary ideologies effectively justified the Christian bourgeois class offensive that reshaped the built form of the city and altered its conceptual geography. It prompted a view of the modern city that 
contrasted its present with the abject past of disorganized, ad hoc Ottoman administration. It partly did so by creating an abject subject of Muslim Cretans, and organizing it in specific geographic locations. It is only seemingly paradoxical that these very same abject spaces are today rendered in a nostalgic manner as the creation of the peaceful coexistence of "common people" in their meandering alleys; seemingly, because from the moment of their inception in official schemes of city building, they were already "older" spaces, representing the Ottoman past of the city, which ended with the triumph of Christian Cretans over their Muslim compatriots.

\section{Interethnic Violence, Nationalism, Religion and Urban Space: From Stories to History}

The wholesale reshuffling of urban space in ethnic terms accompanied the process of solidifying local, contingent, person-specific stories into grand narratives of nationalist history. Both these processes-shaping space and consolidating the history of this space-share the same logic of transforming smaller, seemingly unconnected events of local significance into an organized, interconnected whole. At the same time, however, they create meaning for these smaller parts that they may not have had in advance. For example, the street known locally as karteria was at the beginning of the century a badly lit alley that led from a gambling house for the wealthier urban professionals to the center of the city. Local (Christian) lore exploited the similarity of the name karteria derived from the Italian quartiere, for the Venetian military quarters that stood in the street, with the Greek karteri, meaning ambush, urged possibly by the frequency of muggings in the area. Although Christian thieves were possibly equally involved in such exploits, the local lore has it that the name derived from the ambushes set up by Christian vigilantes that caught Muslim thieves in their getaway from robbing Christian gamblers, and then returned the money to the victims (Vardavas 1971b).

As unlikely and convoluted as this story sounds, the way it is narrated is meaningful. It seeks to connect stories of male prowess with struggles for the organization of space and the creation of ethnic subjects in the same process (compare Herzfeld 1988). The exploits of Christian and Muslim hoodlums in the city are a mainstay in accounts of the times (e.g., Vardavas 1971a, 1973; see also Zaimakis 1999). These accounts make it clear that their behavior transgressed religious or ethnic boundaries and sought to establish "turfs" as networks of personal status and prestige. The example of one Ali Obashi, a fierce former lieutenant in 
the Ottoman gendarmerie, who physically attacked a fellow Muslim for abusing a Christian passer-by in religious terms, is instructive. It is clear that Ali was at this particular time more interested in keeping order over his "turf" and preserving good relations with neighboring Christians, than playing on religious or ethnic difference. This behavior becomes even more relevant to discussions about violence and coexistence when we learn that this same Ali Obashi was arrested for massacring Christians during the August 25 riots in 1898 (Dermitzakis 1962: 31). Relations with other male hoodlums, based on a violent male code of honor became more important than religious difference in the context of everyday diplomacy even in peaceful times (see Bryant this volume). These exploits were made iconic of the widespread occurrence of violence in interpersonal relations. The stories of manly feats that accompany the exploits of such men point to a narrative organization of customary, quotidian violence that transforms it into a commonsensical occurrence in the community (Ferrándiz and Feixa 2007: 57; Scheper-Hughes 1997). Violence in interpersonal relationships was constitutive in many aspects of social life in the city at the end of the nineteenth century. From establishing the boundaries of a social group such as a neighborhood to resolving interpersonal disputes, to opposing challenges to one's integrity and honor (see Anagnostopoulos 2007 for extensive discussion). Historical circumstance, however, selectively transformed the stories about local hoodlums of both religious faiths into a series of symbolic statements of Christian retributive violence.

The nineteenth-century irredentist "state of emergency" legitimized a number of common criminals as bulwarks of the struggle for liberation (e.g., Bien 2001: 373), while the military and political organization of Cretan insurgents was based on a network of status and manly violence developed in rural areas (Anagnostopoulos 2007: 90-94). As the "modern" Autonomous Cretan polity was instituted, it had to perform a double feat: delegitimize personal violence by arresting and marginalizing its perpetrators as insults to the civilization and propriety of the "new" city, and at the same time make it heroic by ousting it into the past, incorporating it into the national narrative, and forgetting the mundane character of personal violence by referring to exceptional acts of collective violence. We have already seen how the "Turkocretan" subject was constituted as a violent subject symbolic of the institutional violence of the Ottoman regime. In spatial terms, the activity of hoodlums of both religions was morally colored by the abject urban spaces that it demarcated as its turf. That these spaces were the habitation of the majority of impoverished Muslims was, of course, no coincidence. Finally, the defining violence of Christian discourses had to be invested with historical 
legitimacy, which would simultaneously justify the widespread social violence of the time, especially when coming from Christian subjects. Thus, the violence of "Turkocretans" was an inherent trait, caused by their religious affiliation and their corruption by the "Turkish" maladministration (Kondylakis 1896a), whereas the violence of the Christians was a legitimate strategy, in view of their irredentist struggle.

What does this mean for the researcher who tries to establish the climate of peaceful coexistence between the two creeds? First, that coexistence is not necessarily peaceful. Reconstructions of it, especially in fiction, had a specific, progressive program that sought to present the city as a cosmopolitan haven, broken down by nationalist excesses. However, historical research makes it clear that violence was a common occurrence, moving both vertically (people oppressed by their more powerful compatriots) and horizontally (across religious groups). Especially in the case of Iraklio, to employ notions of cosmopolitanism is to ignore the plurality of antagonisms at the heart of this urban society. Second, it means that the creeds themselves were social subjects that were created by violence not on the everyday level, but rather when this violence became transvaluated (Tambiah 1996: 191) by nationalist or religious retelling. The process of transvaluation takes everyday disputes over "turf" - either personal or group territory-and invests them with imagined meaning that presupposes something "beyond" the direct community of interest, a utopian space opened by the dream-nation (Gourgouris 1996). What changes in periods of widespread interethnic violence is that precisely this common occurrence of violence is orchestrated around a common cause, which in turn justifies the proliferation of such violent incidents. Whereas the national dream proposes the abolition of all violence, its political program is to justify the violence that engenders it, and in the course of this, it allows for personal strategies of identification that justify all instances of interpersonal violence through reference to a common cause.

This process of justification is inextricably linked with the recreation of the built fabric of the city. In fact, as I have proposed in this paper, it is the very same process that produces modern ruins and furnishes them with nostalgic histories. This is a process resulting in social fetishism in the classic sense of the term, in that it creates material "testimonies" of the cosmopolitan city that occlude the social processes that have enabled them to exist at all; it seeks to present luxurious mansions, official buildings, and humble abodes as one thing, created by the linear advancement of one people through history. However, the hidden genealogy of antagonism inherent in struggles over space comes out in the stories told about the space itself. Historical and anthropological re- 
search needs to read it, instead of opting for the romantically inflected nostalgia for ruins that is inherent in notions of past cosmopolitanism.

Aris Anagnostopoulos holds a PhD in social anthropology and an MA in urban history. His research focuses on the ways in which the material remains of the past are conceptualized and acted upon by contemporary societies, and the ways in which the past influences the shaping of social space. His recent work brings together the concerns and methods of archaeology and social anthropology, in the emergent sphere of archaeological ethnography. He is an honorary lecturer at the School of European Culture and Languages and a post-doctoral researcher with the Initiative for Heritage Conservancy in Greece; he currently serves as assistant director of the Irish Institute of Hellenic Studies at Athens.

\section{Notes}

1. The municipality uses the transliteration Heraklion, whereas in this article I use the much simpler and demotic Iraklio.

2. While in other areas of the Greek state this process was a conscious effort of state authorities in order to "Hellenize" local populations, in Crete the Autonomous State at least acted as a buffer to interethnic violence and attempted to safeguard the rights of Muslims, in an effort to dampen emigration and prevent economic stagnation. Local initiative was paramount in reshaping the urban environment and excising Muslim landmarks from the city, which accounts for the differences in built heritage between Cretan cities, as well as their differential management (see, e.g., Herzfeld 1991).

3. In 1881, there were 6,421 Christians in total in the city and 14,597 Muslims (Stavrakis 1890: 68). In 1900, there were 10,753 Christians and 11,659 Muslims (Kritiki Politeia 1904). In 1911, there were 15,877 Christians and 9,248 Muslims (Efimeris tis Kyberniseos 1911).

4. The local name for the Venetian castle at the Iraklio port.

5. This is another phonetic allusion, as the one described in the following paragraphs: the word berbantis in Greek means the dissolute philanderer. While the etymology of the word probably derives from the Italian birbante, which in turn derives from birba (crook, bum), it is phonetically close to the Turkish berbat (terrible, disgusting). Later commentators, e.g., Vardavas (see references), use the phrase berbat mahalle to refer to the neighborhood as a place of ill-repute that berbantis males would frequently visit, unaware of its original Turkish meaning (terrible neighborhood). I am indebted to the editor of this volume for alerting me to this particular detail.

\section{References}

Aggelakis, Emmanouil. 2004. Apomnimonevmata. Athens: Estia. Alexiou, Elli. 1978 (1938). Ypoleimmata Epaggelmatos. Athens: Kastaniotis. 
Anagnostopoulos, Aris. 2007. "From 'Tourkopolis' to 'Metropolis': The Creation of Public Space in Early Twentieth-Century Iraklio, Crete." Ph.D. dissertation, Department of Social Anthropology, University of Kent, Canterbury, UK.

- 2011. "Picturing Public Space: Ethnicity and Gender in Picture Postcards of Iraklion, Crete, at the Beginning of the 20th Century." In Audiovisual Media and Identity in South-Eastern Europe, ed. E. Pistrick, N. Scaldaferri, and G. Schwörer, pp. 171-191. Newcastle Upon Tyne: Cambridge Scholars Publishing.

Andriotis, Nikos. 2004. "Christianoi kai Mousoulmanoi stin Kriti 1821-1924." Mnimon 26: 63-94.

Anagnostopoulos, Aris. 2014. "Writing the Cretan woman. Gender and society in two ethographies of fin-de-siècle Crete". Journal of Modern Greek Studies 32(1): 81-110.

Ballinger, Pamela. 2003a. History in Exile: Memory and Identity at the Border of the Balkans. Princeton: Princeton University Press.

—_. 2003b. "Imperial Nostalgia: Mythologizing Habsburg Trieste." Journal of Modern Italian Studies 8(1): 83-101.

Bien, Peter. 2001. “O 'Kapetan Michalis' : Ena ateles politiko mithistorima.” In I Teleftea Fasi tou Kritikou Zitimatos, ed. T. Detorakis and A. Kalokerinos, pp. 369-388. Iraklio: Municipality of Iraklio.

Bowman, Glenn. 2003. "Constitutive Violence and the Nationalist Imaginary: Antagonism and Defensive Solidarity in 'Palestine' and 'Former Yugoslavia.' Social Anthropology 11(3): 319-40.

- 2007. "Constitutive Violence and Rhetorics of Identity: A Comparative Study of Nationalist Movements in the Israeli-Occupied Territories and the Former Yugoslavia." In Multidisciplinary Perspectives on Peace and Conflict Research: A View from Europe, ed. F. Ferrándiz and A. Robben, 117-46. Bilbao: University of Deusto.

Calhoun, Craig. 2008. "Cosmopolitanism in the Modern Social Imaginary." Daedalus 137(3): 105-14.

Cheah, Pheng. 1998. "Introduction, Part II: the Cosmopolitical Today." In Cosmopolitics: Thinking and Feeling Beyond the Nation, ed. P. Cheah and B. Robbins, 20-41. Minneapolis: University of Minnesota Press.

Députation des Musulmans de Crête. 1896. Les Événements crétois du 24 mai 1896: Par la députation des Musulmans de Crête. n.p.

Dermitzakis, Manolis. 1962. To Palio Kastro, Vol. 1. Iraklio: n.p.

—_. 1963. To Palio Kastro, Vol. 2. Iraklio: n.p.

Detorakis, Manolis. 2001. "Kinonikes epiptosis sto diamerisma Irakliou sti metapoliteftiki epanastasi tou 1895-1898." In I Teleftea Fasi tou Kritikou Zitimatos, ed. T. Detorakis and A. Kalokerinos, pp. 109-126. Iraklio: Municipality of Iraklio.

Detorakis, Theoharis. 2005. Neokritika Meletimata, Vol. I. Iraklio: Vikelea Municipal Library. 
Driessen, Hank. 2005. "Mediterranean Port Cities: Cosmopolitanism Reconsidered." History and Anthropology 16(1): 129-41.

Efimeris tis Kyberniseos. 1911. "Apografi tis Nisou Kritis tis 4-5 Iouniou 1911." Efimeris tis Kyberniseos. Chania: Typografeio Kritikis Politeias.

Ferrándiz, Francisco, and Carles Feixa. 2007. "An Anthropological View of Violence." In Multidisciplinary Perspectives on Peace and Conflict Research: A View from Europe, ed. F. Ferrándiz and A. Robben, 51-76. Bilbao: University of Deusto.

Fine, Robert. 2003. "Taking the Ism Out of Cosmopolitanism." European Journal of Social Theory 3: 451-70.

- 2006. "Cosmopolitanism and Violence: Difficulties of Judgment." The British Journal of Sociology 57(1): 49-67.

Foucault, Michel. 1997. "The Birth of Biopolitics." In Michel Foucault, Ethics: Subjectivity and Truth, ed. P. Rabinow, pp. 73-80. London: Penguin.

Fournarakis, Konstantinos. 1929. Tourkokrites. Chania: I. Giannakoudakis.

Freri, Marika. 1979. To Kastro Mas. Athens: Kastaniotis.

Gourgouris, Stathis. 1996. Dream Nation: Enlightenment, Colonization, and the Institution of Modern Greece. Stanford, CA: Stanford University Press.

Hansen, Thomas Blom. 2001. Wages of Violence: Naming and Identity in Postcolonial Bombay. Princeton, NJ: Princeton University Press.

Herzfeld, Michael. 1988. The Poetics of Manhood: Contest and Identity in a Cretan Mountain Village. Princeton, NJ: Princeton University Press

—. 1991. A Place in History: Social and Monumental Time in a Cretan Town. Princeton, NJ: Princeton University Press.

— 2002. "The Absence Presence: Discourses of Crypto-Colonialism." The South Atlantic Quarterly 101(4): 899-926.

Humphrey, Caroline. 2012. "Odessa: Pogroms in a Cosmopolitan City." In Post-Cosmopolitan Cities: Explorations of Urban Coexistence, ed. C. Humphrey and V. Skvirskaja, pp. 17-64. New York: Berghahn.

Ilbert, Robert, and Ilios Yannakakis. 1997. Alexandria, 1860-1960: The Brief Life of a Cosmopolitan Community. Alexandria, Egypt: Harpocrates Publishing.

Karelis, Manolis. 2001. “25 Avgoustou 1898: I megali sfagi tou Irakliou." In I Teleftea Fasi tou Kritikou Zitimatos, ed. T. Detorakis and A. Kalokerinos, pp. 481-498. Iraklio: Municipality of Iraklio.

Kofman, Eleonore. 2005. "Figures of the Cosmopolitan: Privileged Nationals and National Outsiders." Innovation: The European Journal of Social Sciences 18(1): 83-97.

Kondylakis, Ioannis. 1896a. “Oi Tourkokritikoi. Pos Efytrosan." Estia 15 June.

_. 1896b. "Oi Tourkokritikoi. Pos Eine Simeron." Estia 16 June.

Kritiki Politeia. 1904. Statistiki tis Kritis. Plithismos 1900. Chania: Typografeio Kritikis Politeias.

Margaritis, Giorgos. 2001. "I Kriti sta 1896-1898: Kinonikes anakatataksis se metavatiki periodo." In I Teleftea Fasi tou Kritikou Zitimatos, ed. T. Detorakis and A. Kalokerinos, pp. 103-108. Iraklio: Municipality of Iraklio. 
Millas, Iraklis. 2006. "Tourkokratia: History and the Image of Turks in Greek Literature." South European Society and Politics 11(1): 47-60.

Municipality of Heraklion. 2004. Heraklion, A City through the Ages [DVDROM]. Iraklio: Municipality of Iraklio.

Ortaylı, İlber. 1999. İmparatorluğun En Uzun Yüzyılı. Istanbul: İletişim Yayınları.

Peponakis Emmanouil. 1997. "Eksislamismi kai Epanekchristianismi stin Kriti, 1645-1899.” Nea Christianiki Kriti, Special Issue 2.

Planakis, Stavros. 2011. Tourkokritiki Logotehnia-Anthologio. Chania: n.p.

Robbins, Bruce. 1998. "Introduction, Part I: Actually Existing Cosmopolitanism." In Cosmopolitics: Thinking and Feeling Beyond the Nation, ed. P. Cheah and B. Robbins, 1-19. Minneapolis: University of Minnesota Press.

Rosaldo, Renato. 1989. "Imperialist Nostalgia." Representations 26: 107-22.

Said, Edward. 1978. Orientalism. London: Routledge and Kegan Paul.

Sifneos, Evridiki. 2005. 'CCosmopolitanism' as a Feature of the Greek Commercial Diaspora." History and Anthropology 16(1): 97-111.

Stavrakis, Nikolaos. 1890. Statistiki tou Plithismou tis Kritis. Athens: Palligenesia.

Svolopoulos, Konstantinos. 2005. O Eleftherios Venizelos kai i Politiki Krisis is tin Aftonomon Kritin, 1901-1906. Athens: Ikaros.

Tambiah, Stanley, 1996. Levelling Crowds: Ethnonationalist Conflicts and Collective Violence in South Asia. Berkeley: University of California Press.

Theodossopoulos, Dimitrios. 2006. “Introduction: The 'Turks' in the Imagination of the 'Greeks." South European Society and Politics 11(1): 1-32.

Tzedaki-Apostolaki, Lena. 2001. “Tourkokritikoi: anazitisi mias taftotitas." Istorika 34 .

Vardavas, Minas. 1971a. "O kapetan Giannikos." Ethniki Foni, 25 January.

__. 1971b. "Ta Mpempletzidika." Ethniki Foni, 21 June.

_. 1972. "I Brises." Ethniki Foni, 3 July.

—_. 1973. "G. Magriplis.” Ethniki Foni, 8 October.

Waley, Paul. 2009. "Introducing Trieste: A Cosmopolitan City?” Social E Cultural Geography 10(3): 243-56.

Zaimakis, Yannis. 1999. "Katagogia Akmazonta": Parekklisi ke Politismiki Dimiourgia sto Lakko Irakliou, 1900-1940. Athens: Plethron.

Zei, Eleftheria. 2005. Xoros ke Fotografia: To Iraklio apo tin Othomaniki Aftokratoria stin Kritiki Politia. Athens: Politistiko Idrima Omilou Pireos.

Žižek, Slavoj. 1989. The Sublime Object of Ideology. London: Verso. 
\%. Chapter $4 \cdot 6$

\title{
Trade and Exchange in Nicosia's Shared Realm
}

\author{
Ermou Street in the 1940s and 1950s
}

\author{
ANITA BAKSHI
}

\begin{abstract}
A
river once ran through the center of Nicosia's walled city. It was diverted by the city's Venetian rulers, and the "riverbed streets" later formed the backbone of the east-west route through the city-a major commercial corridor that ran along Ermou Street. ${ }^{1}$ It is along these streets that Cypriots from all communities came together-streets that contained a mixture of Greek, Turkish, and Armenian businesses (Marangou 1995). This historic urban topography has endured, with most of these riverbed streets falling within the United Nations-controlled Buffer Zone, radically transformed from spaces of cooperation into lines of division. This division, first termed the Mason-Dixon Line, a wire fence following Paphos and Ermou Streets in the late 1950s, gelled in 1963, and became permanent with the arrival of Turkish troops on the island in 1974 (Hocknell 2001). What is commonly known about this part of the city is that it was an important commercial area, well used by both Greek Cypriots and Turkish Cypriots, as well as other ethnic minorities, prior to partition. The importance of this part of the city is recognized in that it was one of the few ethnically mixed areas of a city otherwise defined by the Ottoman mahalle structure of generally segregated neighborhoods. The significance of this area is often mentioned in other texts that outline the history of the city, and it is also referenced in idealized reconstructions of a past of brotherhood and unity when Greek and Turkish Cypriots were sharing this area. Yet, the scholarship dealing with this site is thin, and little detailed information about it is available, thus enabling reductive depictions that serve these reconstructions. ${ }^{2}$ This is a history that had remained unwritten, and had not found its way
\end{abstract}


into public discourse so that we might interrogate it as a more substantive resource.

This chapter will attempt to rebuild the lost topographies of the Buffer Zone-spatial, social, and commercial-using the few resources available and relying most heavily on the memories of those who knew this area in the 1950s, before intercommunal conflict changed the nature of the city. It examines what these memories can reveal about the slow process of change from a city of coexistence to the spatial segregation of the two communities. I use Simmel's discussion of "the stranger" to explore how the spatial framework of the marketplace street supported both the phenomena of "nearness" and "remoteness" as the street changed from a space of coexistence to a site of conflict. These memories aid in the reconstruction of a clearer picture of the idealized description of the "mixed city" of Nicosia, using memories associated with the spatial framework of the Ermou marketplace to broaden understandings of social relations between the city's diverse communities prior to division.

These streets contained many shops, almost all of which were long and narrow, lit only by the entrance and an arsera, or small high window. Therefore the tall wide doors were often left open, creating a rich and vibrant streetscape. Prior to division, residents from all over the city came to shop in these streets, where merchants and farmers from surrounding villages traded their goods. Today, however, this part of the city is nearly a reverse image of this past incarnation, its activity and density replaced by emptiness and silence. To use Dylan Trigg's words regarding his experience of the temporality of ruins: "There is a sense of being displaced here, of having come to a scene too late, as though the presence is defined by what fails to materialize in the present" (Trigg 2009: 98).

While the nature of the Cyprus problem has changed over the years, being further complicated by developments since 1974, such as the demographic impact of large numbers of migrants from mainland Turkey and the accession of the Republic of Cyprus to the EU in 2004, in many ways the area within this set of lines has remained the same since 1974. The layout of its streets and shops remains unchanged, and on some buildings signs still hang that advertise businesses once located there. A journalist allowed to tour the Buffer Zone inside the walled city in 2010 writes: "We come across signs bearing the names of famous entrepreneurs who range from brewers of beer to importers of cars and electrical goods: Fotos Fotiades, Kozakis Galatariotis Bros, Philippou Bros, Hadzikyriakos and others" (Christofi 2010). Because many buildings in this area were constructed from mud-brick, they have been slowly eroding, and there have been many roof and facade collapses. The Nicosia 
Master Plan (NMP) team has worked to reinforce several buildings, but they are only allowed to do as much as is necessary to prevent their collapse, supporting crumbling facades with wooden scaffolding. ${ }^{3}$ Thus a peculiar situation exists in this swath of land in the center of the city: buildings cannot be altered or demolished, and the effects of time can clearly be witnessed on their scarred figures.

The rationale for studying Nicosia through an investigation of placebased memories is connected to the problematic nature of official historical narratives related to contested histories, where certain events, chronologies, and perspectives are remembered while others remain unregistered, officially relegated to the realm of the forgotten. In regions of conflict, histories are contested and competing, often resulting in national narratives that are heavily imposed through official channels of history and memory. I will argue in this chapter that in Cyprus, where official repositories of history like archives and textbooks can be heavily manipulated, an investigation of place can prove a valuable resource for understanding and challenging these competing histories.

The "Cyprus Problem" today remains unresolved, and the fate of the Buffer Zone, which stretches for 180 kilometers through the island, remains suspended; but perhaps the most contested terrain of all in Cyprus today is that of history. Official Turkish Cypriot and Greek Cypriot historical narratives represent the contested past in starkly different ways (Papadakis 2008). These divergent narratives present different chronologies, where different periods and events are remembered and forgotten by each side. Additionally, Nicosia in the past is represented in different ways: either as a city of brotherhood, where different communities lived together in complete harmony, or as a city segregated along communal lines (Bakshi 2012a). These factors have made it difficult to understand the nature of everyday coexistence and conflict between communities in Cyprus, necessitating the development of new theoretical and methodological tools arrived at through a close investigation of peoples' individual and collective engagements that can enrich our understandings of this space. Such tools can allow us to describe how diverse populations negotiate, through actual relations, the daily practices of sharing space and living together, and also to understand how enmity is created in the transition to conflict. In this chapter, I attempt to do this through a detailed spatial investigation from my perspective as an architect, looking closely at the spatial configuration and materiality of the Ermou marketplace and how it functioned in structuring social relations.

Often the Buffer Zone is rendered simply as a line on the map. But it does have thickness-a thickness that extends beyond its edges as the de facto Buffer Zone, neglected and sparsely populated contiguous 
areas, which radiate out from these edges deeper into the walled city. This chapter will argue that this part of the city has always "extended beyond" its apparent borders. The Ermou marketplace streets, while of a different nature than the rest of the city, introduced cohesion and structural integrity to the city as a whole. Market areas generally encourage the appearance of other urban activities and programs at their edges. These are areas of the city that have their own associations and symbolic meanings: areas that operate on a different clock from the rest of the city, known for trade, exchange, and a multitude of possibilities (Calabi 2004). This chapter, in rebuilding these topographies, aims to highlight the importance of these shared streets to the functioning of Nicosia as a mixed city of diverse populations.

A more comprehensive rendering of the Ermou marketplace will assist in broadening understandings of the nature of coexistence of diverse populations in mixed cities. ${ }^{4}$ This is especially important in contested or divided cities where, as in Nicosia, much of the rhetoric about the past centers on the city as either intermixed or segregated. Scholars have challenged this reductive understanding of place, proposing instead a more dynamic and flexible understanding of cities. Doreen Massey describes space as a composition of multiple trajectories, reading it as a medium that involves time and allows for the simultaneity of multiple stories within its framework. This allows for an understanding of the city as an entity that is neither "diverse" nor "homogenous." She views space as "the sphere of the possibility of the existence of multiplicity in the sense of contemporaneous plurality; as the sphere in which distinct trajectories coexist; as the sphere therefore of coexisting heterogeneity" (Massey 2005: 8). This research attempts to examine Nicosia along these lines, as a city where, prior to the 1950s, different communities were dependent upon each other, while at the same time maintaining varying degrees of separation. The picture of life that emerges from this research falls outside of the overly strict definitions of the city as either intermixed or segregated. Rather, the city's mixed nature was in some ways facilitated by its segregation.

The Buffer Zone is a gap in the city-a physical gap and a gap of the imagination, separating differing interpretations of the past. There also exists a gap in knowledge about this place and the way of life it at one time encapsulated. The limited existing scholarship on this site reveals that it was once the city's main marketplace, well-used by all Cypriots, and that there are two divergent official narratives about life in the city before 1974 (Papadakis 2005). I argue that this makes it important to now go back to the city as the base, and then rebuild a richer and more nuanced depiction of life in the most important and ethnically mixed 
urban space of the city. This investigation of everyday life complements the histories, and it also narrates, using individuals' stories, how people can become alienated and separated, even while sharing the same city center.

The reconstruction of the topographies of the Buffer Zone was accomplished through a process of piecing together information from different sources-including archives, newspaper advertisements, commercial catalogues, ${ }^{5}$ land registers, and photographic surveys-and emplacing them on maps of the walled city. ${ }^{6}$ These maps and visual prompts were then used in loosely structured interviews with Greek Cypriot, Turkish Cypriot, and Armenian Cypriot shopkeepers who once lived or worked in this part of the city, allowing themes to emerge. ${ }^{7}$ The spatial framework of this site was used to trigger memories in the people who once worked there, enabling them to provide narratives describing a lost way of life and the relatively undocumented dynamics of intercommunal commercial and social relations. A study and discussion of place allows access to these types of memories because these places provided the setting or background for the activities of daily life; and they serve now as a setting for memory. As this chapter will outline, the Buffer Zone was and is so crucial to the functioning of this city and the relations between its populations that it certainly merits a closer, more detailed investigation-one that zooms in, to elucidate how the city functioned as a whole, and how it broke apart. ${ }^{8}$

\section{Life of the Ermou Marketplace}

By tapping into the resource of these maps and narratives a scenario can be composed of the rich street life along Ermou in the early 1950s-of narrow shops with workers sitting outside, and of recognizable street vendors with their distinct calls for advertising goods. Most of the shopkeepers did not remember every detail about life in this area, nor were they able to remember time frames with much specificity. Rather, their remembrances were of certain images and sounds-memories of moments and places that have been strong enough to persist. It is these memories that begin to reveal the outlines of the narrow shops of the Ermou marketplace. ${ }^{9}$

These streets would fill with people early in the morning. Ali, whose father ran a grocery on Ermou, remembers opening the shop at 6:30 AM and selling around three hundred loaves of bread most mornings within the first two hours of business. His shop was located around the corner from a Greek merchant who ran one of the city's most recogniz- 
able businesses, Tsaiousis 1,000,000 Things. Their shops were near the intersection of Ermou and Goldsmiths' Street, also known in Turkish as Köprü Başı, the "bridgehead," as it historically was the location of one of the main bridges that spanned the river. In Greek it was known as Stavro Pazaro, the "cross-market." 10 This intersection could be considered the center of the marketplace streets, and many important merchants were located here. Monyatis, Klerides, Agrotis, and Kokinos were popular glassware shops. Nearby was a large KEO shop, selling the famous beer of Cyprus since 1951, as well as Platanis Wines and Spirits. Just to the east were smaller, but equally well-known shops, such as the Galip Grocery, Camberis Clothing, Varnavas Nicolaou the timber merchant, Irfan Hussein's large retail store, and the Çıraklı confectionary.

The shopkeepers' memories describe the crowded nature of the street with people sitting outside of their shops, and at outdoor cafes during siesta time, which lasted from 1:00 PM to 4:00 PM during the summer. This was a mandated time of rest, enforced by the British, and people were required to close their workshops for these three hours. At 1:00 PM every working day a horn would sound from the nearby power station, marking the beginning of siesta. While some went home for lunch and a nap, others would sit at the cafes playing cards or backgammon. They sat on traditional Cypriot chairs, wooden with woven seats, in the cafes or outside of their shops. A frequent sight on the streets would be a boy holding a metal tray, delivering short cups of strong coffee. The streets were often enlivened by coppersmiths and blacksmiths who would take their work outside. Tassos recalls that as a child he saw two men sitting on Iphestos Street, where most of the coppersmiths were located, hitting a piece of metal and singing a song: "Ash gollarna, ash gollarna, sargolari" - a version of the Turkish song, "aç kollarını, aç kollarını, sarıl bana"- "open your arms and hug me." Photographs from 1957 show what Tassos may have seen: Coppersmiths sit on the street, hammering away at large pans held up between their knees, next to stacked pots and pans of all sizes. These were streets where daily rituals took place in accordance with a common clock, and where different traditions and languages came together.

Just as Iphestos was the street of the coppersmiths, other streets in the marketplace were also known for specific trades. Goldsmiths' was the street of jewelers. Arabacilar Street, "the coachmens' street," was one of the main stops for amaxa, horse-drawn carriages, and was lined with carpenters' workshops. Arasta Street was largely known as a place to shop for shoes and leather goods, and there were many Armenian merchants selling leather, shoes, and textiles. ${ }^{11}$ Among these streets were several outdoor gathering spots such as Platanos, located at the inter- 
section of Ermou and Militou, where a large tree provided shade from the strong Cyprus sun, and many people would gather here throughout the day. Towards the eastern end of Ermou Street, where it became considerably wider, were several factories processing sesame seed oil. The leftover from this process, a delicious paste called kouzvos, was given away to the neighborhood children. Many factories were to be found at this end of Ermou including the Klitos soda factory, the Kulabis flour mill, and Kyriakos Anastassiades furniture factory, well known for the sign above the door that read "VISIT US FOR YOUR OWN BENEFIT." And finally, at the end of Ermou, was the Olympiakos Football Club. Just as individual shops were known for certain features, different parts of Ermou Street were defined by distinct characteristics.

In the center of this activity was the main municipal market called Pantopolio in Greek, which means a place to buy everything, and pronounced as Bandabulya in Turkish. ${ }^{12}$ This market, located at the intersection of three of the most important commercial streets in the city-Ermou, Goldsmiths', and Arasta-could be considered the hingepoint of the city. Everybody shopped in this market, and it was the main outlet for produce and meat. Mustafa, a butcher who has been working at Bandabulya ever since he was a young child in the 1940s, remembers the many languages spoken there-Greek, Turkish, English, and even some Arabic. The market was very mixed, although the Greek butchers were in a separate section selling pork, and it was always crowded. In one of the rare memoirs written about this period, Taner Baybars describes his impression of this place as a child in the 1950s:

We went to the closed marketplace on foot, walking along the road called Arasta which was the hub of haberdashery, lingerie and buttons. That smell from each shop, cool, starchy. The market was always cool. ... The whole place was a mixture of smells. There were rows. Each row smelled differently. One of spices, another one of vegetables and fruit, and another one of fresh blood dripping from newly slaughtered beasts hanging on sharp, shiny hooks. (Baybars 1970: 47)

Photos of Pantopolio taken in the 1950s show that the activity extended out from the large entrances of the market onto the surrounding streets. Just outside the northern entrance, located at the end of Arasta and in front of the Aya Sofya Mosque, ${ }^{13}$ a thick border of vendors defines the edge of the street. Goods for sale are laid out, and vendors push carts with ready-to-eat food. It was not only the buildings and places that defined Ermou, but these vendors were part of the common vocabulary of the streets as well, and, more importantly, part of the common language 
shared by all communities in Nicosia. This language was composed of the repetitive practices of the daily life of the city-practices that were known and recognized by all.

Many shopkeepers remembered the vendor who sold chickens from cages in a street just off of Goldsmiths' and the petrol-seller who travelled the streets with a donkey-cart. But most popular of all were the sellers of sweets and refreshments. They would push their carts of shiamali-made from semolina, yogurt, and syrup-and muhallebi, the characteristic starch pudding of Cyprus, making their rounds through the marketplace, especially in the evening hours. A variety of muhallebi was made from milk, and the most coveted ones were those that came out blackened, the sugar slightly burnt and caramelized. In the mornings vendors would sell a variety of breakfast rolls, the warm and soft koullaria as well as bread rolls baked with halloumi or kaskavalli-a rich cheese with holes that the oil runs through when warm. Perhaps the most interesting vendor was the Turkish woman who sold Oxinindie Lemonade, which she carried in a tank on her back. She wore a belt stocked with glasses, bending over and pouring the lemonade from the tank into these glasses.

The vendors had their own unique calls for advertising their products. "Salebi vraaaaazi...."-"hot salep"-the men would call out who sold this sweet winter drink made from crushed almonds. Some even had their own lyrical sayings; particularly well-remembered was a Maronite man who sold pastellaki, a mixture of nuts and honey pressed into flat bars. He would walk up and down the marketplace streets two or three times a day calling out:

$\begin{array}{ll}\text { To pastellaki to kalo, } & \text { The pastellaki is good, } \\ \text { Mono ego to poulo, } & \text { The only one who sells it is I, } \\ \text { Olo kouna kai athasi, } & \text { All nuts and almonds, } \\ \text { Opkios den fai tha hasi } & \text { Whoever does not eat it loses. }\end{array}$

These vendors and their calls were recognized by all, and in this unassuming way different communities shared these aspects of everyday life in the city.

While this area contained hundreds of small shops, cafes, vendors, and gathering spots, there were several in particular that came up repeatedly in many of the shopkeepers' mappings and remembrances. Many shopkeepers would gather in the taverns on Ermou in the evenings: "a bachelor's life was there, at the bar," says Christos. While the rest of Ermou was quiet in these late hours, the bars and taverns, especially Antonakis, Kikas, and Iraklis, were always crowded. Antonakis 
was a small, narrow bar where people would stop in for a quick drink and a light snack. Tassos remembers being intrigued by these places as a child, wondering about the clear, colorless beverage served there. Through the open doors he would watch the men sitting at small metal tables, eating from plates of olives and halloumi cheese; bottles of One Star Cognac sat on the tables.

Several popular restaurants sold pacha, a hearty soup made by slowly cooking together sheep head or stomach, vinegar, garlic, salt, and pepper. These restaurants were very popular both for breakfast as well as for a late-night meal, opening around 3:00 AM to prepare the soup for breakfast for workers who would begin arriving at 5:00 AM. The most popular was Hadjigeorgios' restaurant, located just north of Ermou. Some claim that Hadjigeorgios would carry cooked sheep eyes, considered a real delicacy, in his apron, popping them into the soup of his special customers. Another popular pacha shop was owned by an Arab from Beirut, who spoke excellent Turkish and also served hummus and pastries similar to börek. Vazken, an Armenian leather merchant who ran a shop on Arasta, remembers that his family would start work very early, leaving their neighborhood near Victoria Road around dawn, to return to their club only in the evening. They would open up shop at 7:00 AM, breaking for a 9:00 AM meal at Parsegh's kebab shop, run by an Armenian who had migrated from Turkey. Some claimed that his was the most popular shop in all of Nicosia. Ermou also hosted dozens of small cafes, which were especially crowded during the siesta hours. Of these, everybody had his or her favorite. Many remember the smell of coffee from Özerlat, a coffee roasters operating since the early 1900s near the southern entrance to Pantopolio. Another roaster, Tahsin Bey, was known for his unique method of preparing coffee without a grinding machine, using a hammer instead. Many hans, or inns, were also located on Ermou, known for specific characteristics and functions (Bakshi 2012b).

Legendary characters were also housed in these streets. Many shopkeepers told stories about Kutsofannis, who owned a small tobacco shop on Ermou. Many made of fun of him, recalling that he was a bit slow, a bit fat, and had a funny way of walking and talking. When Tassos was a child, his father, a soldier in World War I, collected his ration of cigarettes, taking them to Kutsofannis' shop to resell for cash. Tassos would stand outside the shop, and wonderingly stare up the steps at the "Cigarette Buddha." The common knowledge about this character can best be illustrated by an anecdote. Andreas recalls a time when an actor, who of course knew about Kutsofannis, went to his shop to play a joke on him, speaking in the same manner, and walking with a limp. When the 
actor left, Kutsofannis saw him straighten up and walk properly from the door. He became very angry, yelling curses down the street after the actor; and of course, all the shopkeepers on the street laughed. Places on Ermou were known not only for their physical characteristics or the goods they sold, but also for the personalities associated with them. The Ermou marketplace might almost be imagined as a framework in which these characters, sounds, and daily practices were located.

The nature of this area changed greatly beginning in 1958. At the end of two months of arson, destruction, and murder in Nicosia, fifty-six Greeks and fifty-three Turks had died (Panteli 1990: 180). Even after order was restored and negotiations were underway for the eventual independence of a united Cyprus, the city was left divided in crucial ways. I have described this in more detail elsewhere, but for the purposes of this discussion, Pantopolio can serve as example of this change. The tone of an article regarding the municipal market in the Turkish press on 1 July 1958 is telling of the increasing territorial claims being staked in the once mixed commercial center:

The Lefkoşa Municipal Market, which had been closed for the last three weeks, opened yesterday.... Numerous British soldiers with machine guns and billy clubs can also be found occupying the market.... The market's Greek Cypriot shop owners appear to be gone.... I met with the Turkish butchers and green grocers who had the chance to settle back into their old shops again.... The Turkish owners say that the market already belonged to the Evkaf, and therefore it has always been Turkish. They also made the point that there are four municipal markets in the Greek Cypriot areas, and therefore the Greek Cypriots should not claim a right to this market. ${ }^{14}$

Thus after 1958 the Greek butchers and grocers never again sold their goods in Pantopolio. At the end of 1958 several major Ermou marketplace institutions including Bandabulya and the hans-both of which had once encapsulated a particular way of life and the overlapping of spatial, commercial, and social topographies familiar to both communitieswere irretrievably transformed. The intercommunal violence lasted for only two months, but the damage to the city was much more permanent. The topography of the Ermou streets was transformed by the beginnings of division-demarcated by fences, barriers, and patrolling military groups-giving visual expression to the separation of the two communities. Like a zipper pulling apart, the Ermou streets became divided as Turkish-Cypriot businesses relocated north and Turkish-Cypriot residents of these streets left their homes as refugees. 


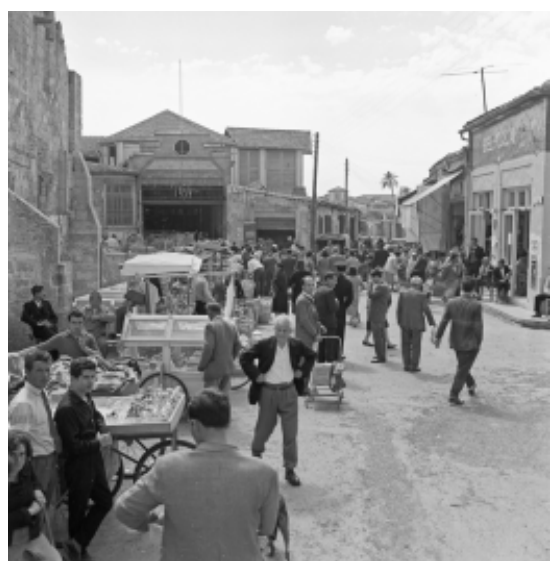

Figure 4.1. "View Near St. Sophia - Late 1950s." The main municipal market Pantapolio/Bandabulya appears in the background. Photograph from The Press and Information Office Archive, 20C.151 (27), Ministry of the Interior, Republic of Cyprus.

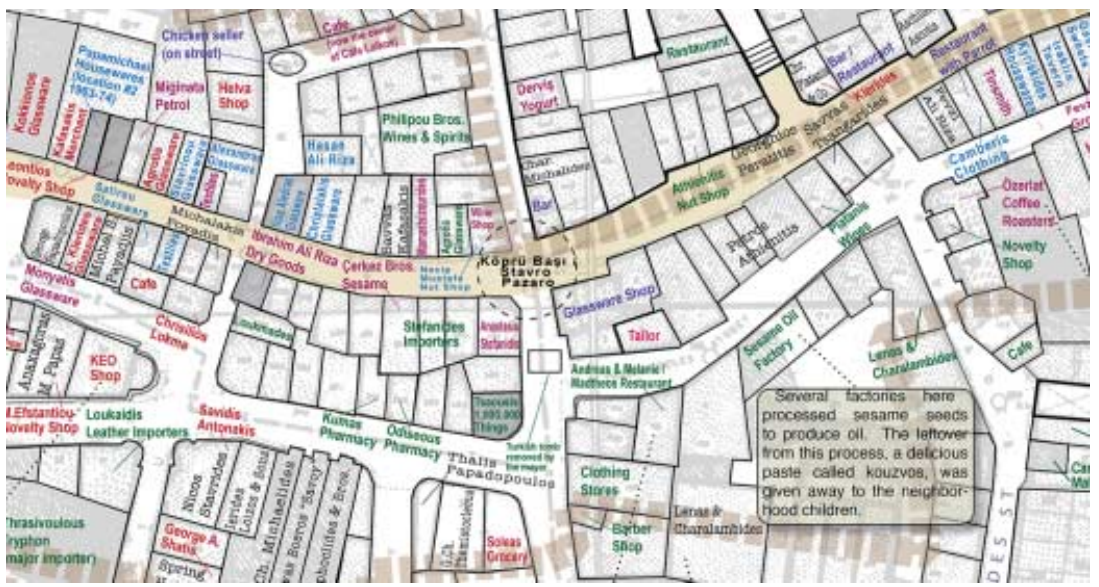

Figure 4.2. A portion of the map created through discussions and mapping sessions with the shopkeepers. Köprü Başı / Stavro Pazaro was a major landmark in the city and many shopkeepers were able to recall shops that once were located in this part of the city.

\section{Exclusion within Inclusiveness}

It was important to here describe the Ermou marketplace in such great detail because the depiction of these streets is critical to understanding how the city functioned as a whole. It is clear that many aspects of daily life in Nicosia's marketplace were shared and understood by Cypriots from all communities. But at the same time, the city was divided in other ways: structured into distinct mahalles, neighborhoods or quarters that were most often ethnically segregated..$^{15}$ 
While these quarters were generally divided along ethnic lines, other public, civic, and commercial areas in the city were quite mixed. The Ermou marketplace perhaps best exemplifies this, but the commercial Ledra and Regena Streets were also used by all communities, as well as Sarayönü Square, considered the clerical center of the city. In this sense, the city was inclusive in that it provided spaces that were shared by all communities, allowing for the participation of all residents in a common urban life. At the same time, this was to some extent limited to certain areas, and the morphology of the city included spaces and urban practices that were formed around exclusion; there were differing degrees of inclusion and exclusion in the city. There were "public" institutions within certain neighborhoods, but these were mainly for the use of defined communities. For example, the Armenians, who were well represented as merchants throughout the city, had their own club, school, and church clustered around their main residential quarter near Victoria Road. The lives of the Armenians of Nicosia were "largely separate" from those of the Greeks and Turks (Pattie 1997: 56), yet significant contact occurred through children's play, business matters, and shops. Their community life was focused around their club:

By 1925 the Armenian club had been functioning in Nicosia for twenty years.... In the library ... were numerous books and periodicals from around the diaspora.... There was also a large room used for dances and meetings, and a small canteen from which coffee and food were served. Upstairs was a space for backgammon and card playing; above that were more rooms, where a few poor families lived.... [There was] a cultural hour at midday on Sundays, after church. These were attended by both men and women and included poetry, music, dramatic recitations, and lectures. People from the community played instruments or sang, and occasionally artists or speakers would come from outside. (Ibid.: 73)

This was a community space and a community life that others did not have, nor expected to have, access to. The Latin community, located near Paphos Gate, had their own space near the Maronite Church. Likewise, the Greek and Turkish communities had their own institutions and spaces for gathering. This social structure existed alongside the understanding of the city as areas and spaces with varying degrees of inclusiveness or exclusion, one that consisted of realms that were shared to differing degrees. Even some aspects of the commercial life of the city were segregated: For instance, there was an order of Turkish tanners, marked by their special sashes and with their own initiation ceremonies in the Ömerye hamam (Bağıșkan 2009: 469). Yet the Turkish and Greek 
merchants and tradesmen came together in the Ermou bazaar. As Bryant notes in her introductory discussion of "multi-scalar sovereignties," there was an understanding of the city as a number of overlapping public and private zones, not one monolithic understanding of the city as "shared space" to which every citizen had the "right" to access.

Additionally, Ermou Street was a very different space for women than it was for men. Vathoula, an 83-year-old Greek Cypriot woman interviewed for this research, remembers the Ermou of the 1950s as being crowded with stores that sold jewelry, lace, fabrics, and shoes. Few women worked in the shops, but many shopped in these streets. While she remembers noticing restaurants and coffee shops from the street, she would never stop there. These were places that were only for men, and if women even glanced inside they would be labeled with a "bad name." Young girls never went to the market alone; they would always be accompanied by mothers, grandmothers, or brothers. The structuring of the Ermou marketplace, then, excluded women from certain parts of the city. As Vathoula's testimony illustrates, it was not considered proper to even look into certain places. ${ }^{16}$ The differential access allowed to men and women exemplifies what was then an accepted structuring of the city into zones of inclusion and exclusion for different groups-much in the same way that it was accepted that the Turks had their own nargile cafes, the Greeks their own taverns, and the Armenians had their club.

There is much in contemporary writing about cities that praises diversity and multiculturalism, and this narrative, as a nostalgic trope, is especially dominant in official Greek Cypriot understandings of what the old city was like. But we can see through the example of the limited access that women had to certain places on Ermou, and the example of the Armenian Club, that this utopic narrative of urban inclusiveness does not stand up to close scrutiny. Rather, the city was inherently structured as different zones, and it was well understood which populations had access to which places. Nicosia worked as a mixed city because of a spatial structure and communal understanding of the city as one that was divided into areas with differing levels of public access and private exclusivity. This overlapping could roughly, for the purposes of this discussion, be divided into three categorical realms, although greater subtlety and nuance would assuredly allow for more. Each of these realms allowed the residents differing levels of participation in the public life of the city, and thus enabled varying degrees of interaction with members of other communities.

The most mixed realm of the city consisted of shared commercial areas, most importantly the Ermou streets. This area structured daily life into a system that was repetitive: certain daily patterns and timings were 
followed by all. This allowed for recognition of people that one would get to know over time, enabling relationships of secondary familiarity. A reference to Georg Simmel's analysis of "the stranger" and human relationships can shed some light on why this realm was so important. In his discussion of "nearness" and "remoteness" Simmel claims that the stranger is someone that we know, and in knowing them we understand that they are not part of "us":

The unity of nearness and remoteness involved in every human relation is organized, in the phenomenon of the stranger, in a way which may be most briefly formulated by saying that in the relationship to him distance means that he, who is close by, is far, and strangeness means that he, who is also far, is actually near. (Simmel 1950: 402-8)

These strangers are not really "conceived as individuals" in the sense that we do not think about their individual qualities, but rather generalize them into a group that is characterized by their being different to us. The shared realm provided by the Ermou streets allowed for the recognition of specific differences-the elements that begin to form the outlines of individuals, distinguishing them from the group as a whole. These outlines may remain hazy. They need not be deep friendships, and indeed they probably often were not, but they do help to create a public life in which the individual can operate comfortably-what Sylvaine Bulle in this volume describes as "co-presence."

Unlike the Jerusalem described by Bulle, however, Nicosia of this period was one that may have experienced the sorts of everyday tensions described by Bryant in her introduction, but where there was little overt hostility. This allowed for a particular habitus to emerge, one constituted by the repetitive nature of interactions and facilitated by the stable pattern of streets and intersections. As Doreen Massey states:

One of the truly productive characteristics of material spatiality [is] its potential for the happenstance juxtaposition of previously unrelated trajectories, that business of walking around a corner and bumping into alterity, of having ... to get on with neighbors ... what is important is that contact is involved and some form of social negotiation. (Massey 2004: 94)

The spatial characteristics of the Ermou marketplace created the possibilities for such activities and mediation. This part of the city had functioned as the main bazaar area for centuries, and its material and spatial characteristics developed because of this location and function. It was once a riverbed, and the narrow and twisting roads that were laid out 
here were originally unpaved market lanes that followed the course of the river. It was the main east-west route through the city, linking two city gates, so hans were established along its course. Plots in this market area were divided to create narrow lots. The wide doors fronting on Ermou provided the main natural light for these narrow shops, and were often left open to the street making the shopkeepers visible to passersby. The few squares and wide streets became places where vendors would establish themselves into recognizable patterns. People could be seen sitting outside of their shops, walking in the streets selling their goods, or resting in cafes during siesta. Thus trade considerations created this particular spatial configuration, and then the material reality of the spaces served to create a well-functioning shared realm for the city-a space that allowed for visual recognition, contact and social negotiation. It was the praxis of the city that allowed for this. In her introduction to this volume, Bryant proposes using the term "constructive ambiguity" to think about a process that allows "certain boundaries to remain in place while finding common ground where it is possible" (p. 23). In this way, differences are bracketed, allowing it to be retained while everyday practices continue. The Ermou marketplace provided a spatial field that could accommodate this kind of negotiation.

The second realm was that of institutions within, or in close proximity to this mixed area: cafes, taverns, or clubs that were segregated and were for the exclusive use of one group or another. These allowed for certain moments when one could withdraw from the shared realm. And finally, the third realm is that of the mahalle, neighborhoods or quarters that were most often ethnically segregated. This allowed for a complete retreat from the mixed, public life of the city into the comfort and familiarity of the mahalle. It is important to state here that some of these neighborhoods, such as Tahtakale and Ömerye, were ethnically quite mixed, and here the familiarity with neighbors also became a defining feature of the mahalle, outside of ethnicity.

\section{Conclusion: Loss of a Structure of Meaning}

While the walled city is mythologically depicted either as a space of comprehensive coexistence or total separation, a closer investigation reveals a more complex urban structure. Communities came together for trade and commerce, working together but generally living in separate quarters. Most of the Turkish neighborhoods were north of the old riverbed, with the exception of Tahtakale and Ömerye to the south. Most of the Greeks lived in the south, with the exception of Ayios Lucas in the north. Still, there were many places in the marketplace streets 
frequented by both communities. These were the tacitly agreed upon places for public intermingling, while intimate neighborhood spots, certain cafes, or ethnic institutions like the Armenian Club, were private, used exclusively by certain communities. An understanding was in place that the city was composed of a number of realms of varying degrees of exclusion or integration.

It is important to introduce this distinction and this gradation into the discussion, as this is lacking in most depictions of the city. For example, a Greek-Cypriot text, Peaceful Co-existence in Cyprus under British Rule, shows a photograph taken in the 1950s at the Women's Market, of Greeks and Turks shopping side by side. This text, using such photographs, seeks to render the old city as a site of unity, prior to 1974 (Kyrris 1977). Yet, these kinds of narratives leave out the forces that changed the city from the 1950s to 1974. Rather than stopping with such photographic "evidence," it is necessary to continue to examine the resource of place, to trace the devolution of the city toward complete division. From the shopkeepers' memories outlined above, it certainly does seem as if these streets contained a common way of life that was recognized by many-a world of recognizable faces and images, a rhythm consisting of the regular flow of known sounds and daily patterns of movement, governed by a common clock. Halbwachs has argued that "[h]abits related to a specific physical setting resist the forces tending to change them" (Halbwachs 1992: 133). This understanding is limited by his assumption of the given dynamics of a stable society. Different dynamics present in sites of conflict, and it is obvious that it was not possible to resist the forces that changed Nicosia from a mixed city to a divided city.

The current material reality of the Buffer Zone represents the loss of a collective way of life. Here an entire web of streets, buildings, occupants, and sounds has been destroyed. While these streets are still in place, the mud-brick buildings that define their edges are eroding away. Signs have rusted, walls have collapsed, and the life that sustained these marketplace streets is gone. What has been lost is what Peter Loizos, in his study of the 1974 refugees from the Cypriot village of Argaki, has called a "structure of meaning." This refers not just to the loss of homes, but rather the loss of highly unique and particular homes, "in which most of their most important social experiences had taken place ... identified with labour, life-history, taste and personality of their owners, and they are in each case a unique combination of subject (owner) and object (construction)." Loizos argues that a refugee can be given a new place to live, a new plot of land, or a new business, "but in the most profound sense, he cannot be given his home again" (Loizos 1977: 8-9). The same can be said of those who were forced to leave the Ermou streets-either 
in 1958, 1963, or 1974-due to political developments and intercommunal conflict. What they cannot find again, what has been lost, is the common experience of the mixed city. The closure of these streets meant the disruption of the everyday lives of all Cypriots. It meant the loss of the smell of warm koullaria breakfast rolls sold on the street, the rhythmic hammering of metal workers, the cries of the salep seller, the endless rounds of jokes about Kutsofannis, the crowds flowing into Pantopolio/ Bandabulya from two entrances in the north and the south, the end of quick drinks of cognac at Antonakis, and the end of long discussions under the shade of Platanos. What has been lost is not just this collective memory, but the collective city itself-the way of life that had existed in the shared realm of the Ermou marketplace.

Again, Simmel's discussion of "the stranger" is useful in thinking about the change in the nature of social relations between Greeks and Turks in Cyprus:

With the stranger one has only certain more general qualities in common, whereas the relation to more organically connected persons is based on the commonness of specific differences from merely general features. (Simmel 1950: 407) ${ }^{17}$

This statement can be used to analyze the changing nature of relations between shopkeepers from different communities. In their remembrances of these streets, shopkeepers spoke about "organically connected persons" such as Kutsofannis or Hadjigeorgos, and other well-known personalities. They spoke of the "commonness of specific differences" such as "he was fat," "he walked funny," "he had a quick temper," "he was good about extending credit." These qualities later changed to "merely general features" about "the Greeks" or "the Turks" as the shopkeepers reminisced about later periods with statements such as "the Greeks were cunning" or "the Turks wanted too much." There was a shift in the dynamics of personal relations between Greeks and Turks, moving those from the other community into the position of "the stranger."

This detailed study of Ermou has attempted to again bring out the "commonness of specific differences." Place-based research has much to offer in bringing to light alternative narratives in contested environments where alternative histories may be unavailable or obscured by official versions. The retrieval of memories from the resource provided by the Ermou marketplace does not serve simply to enable nostalgia for this lost past. Rather, if a shared future is to be possible in Cyprus, a recognition of a shared connection to place, by all Cypriots, can serve as a useful foundation for dialogue and exchange. 
Anita Bakshi teaches in the Department of Landscape Architecture and the Cultural Heritage and Preservation Studies (CHAPS) Program in the Department of Art History at Rutgers University. Following several years in architectural practice in Chicago, California, and Istanbul, she received her Ph.D. in the History and Theory of Architecture from Cambridge University, where she was a member of the Conflict in Cities research group. She is interested in the relationship between memory and materiality and engages in design research that looks for new forms for monuments, memorials, and other commemorative structures.

\section{Notes}

1. The name of this street in English is Hermes Street, and in Greek and Turkish it is Ermou or Ermu, pronounced the same. In this chapter I will refer to it as Ermou, as this is the name by which it is recognized by all shopkeepers interviewed for this research.

2. I have described elsewhere the significance of this area in the construction of the differing Greek Cypriot and Turkish Cypriot "myths" of the city (Bakshi 2014).

3. The NMP is a bicommunal initiative involving the Greek-Cypriot and Turkish-Cypriot communities. It was established in 1981, largely at the initiative of the mayors of the two sides of the city. Since that time they have worked to create an overall master plan for the city.

4. There is significant scholarship that addresses this issue in cities in the former Ottoman sphere. For instance, Gilson Miller and Bertagnin have looked beyond the dimensions of segregation in these communities, arguing that apparent fixed boundaries were perhaps more fluid than previously thought (2010).

5. The Cyprus Industrial, Commercial, and Professional Guide and The Cyprus General Directory contain listings and advertisements of businesses in the old city prior to division. For this research I consulted annual issues dating from 1946-1951. These catalogues feature advertisements for many shops along formerly important commercial streets such as Ermou, Arasta, Yeşil Gazino, Kykko, Ledra, and Libertis Streets.

6. As the existing maps gave no indication of street addresses, it was necessary to use partial Evkaf property registers and photographs of buildings taken during the Buffer Zone Survey in order to connect the building plots with door numbers. Issues of the Cyprus Mail newspaper from the 1940s and 1950s provided additional information about shop addresses through advertisements published by vendors in the back pages.

7. I conducted a series of interviews with these shopkeepers in Nicosia, meeting with them regularly in 2010-11. Eleven Greek Cypriots, twelve Turkish Cypriots, and two Armenian Cypriots were interviewed. The names of individuals appearing in the text have been anonymized. 
8. As Dennis Cosgrove has stated, urban archeology works by "mapping the stratigraphy of material deposits stretched across former urban space." These mappings then can be used to "reconstruct not only a city's physical appearance but also its social, political, commercial and religious life" (1986: 169).

9. Unless otherwise noted, most of the material in this section comes from interviews conducted with the shopkeepers.

10. Interviews with the shopkeepers revealed that different communities at times used common names to describe places in Nicosia, and in other cases described them using linguistically specific referents.

11. At the foot of Arasta was Lokmacı Krikor, an Armenian maker of lokma, fried sweet dough, who unwittingly gave the name to the barricade that was to be built in front of his shop in 1964, the Lokmacı Barikat, which is the name by which the Ledra Street crossing is known today in Turkish.

12. While Pantopolio was the main market, there were smaller weekly markets as well such as the Gynaikobazaro, the Women's Market, which was also mixed. This market was south of Ermou, and bordered on one side by the popular north-south commercial Ledra Street. An open structure, consisting of two sets of slender columns supporting a wooden pediment roof with arched vault, defined the crowded market.

13. This former Gothic cathedral, which had been commonly known as the Aya Sofya Mosque, was renamed the Selimiye Mosque in 1958. Tensions between the Greek Cypriot and Turkish Cypriot communities was reflected in many such name changes, such as the names of street names, in 1958.

14. Türk Belediye Çarşısı açıldi [The Turkish Municipal Bazaar opened], 1958.

15. For example, the census of 1946 shows that Phaneromeni, a neighborhood in the south, had a population of 10 "Mahomedans" (Turks) and 1,065 "Non Mahomedans" (mainly Greeks). Tahtakaleh, also south of the riverbed streets, had 518 "Mahomedans" and 902 "Non Mahomedans." The neighborhood of Emerieh (Ömerye) had a population of 249 "Mahomedans" and 917 "Non Mahomedans." In the north, Ayios Lucas had a population of 536 "Mahomedans" and 263 "Non Mahomedans." Unlike Phaneromeni, these neighborhoods were the most mixed in the city.

16. According to Doreen Massey "not all the 'others' whose existence and difference were so vital to the establishment of the modern sensibility were located in distant regions of the planet. There were also 'others' within ..." including women (Massey 2005: 92-93).

17. See also Rebecca Bryant's description of George Simmel's analysis of "the stranger" in her 2004 study, Imagining the Modern: The Cultures of Nationalism in Cyprus (Bryant 2004: 186).

\section{References}

Bağışkan, Tuncer. 2009. Ottoman, Islamic, and Islamised Monuments in Cyprus. Nicosia: Cyprus Turkish Education Foundation.

Bakshi, Anita. 2012a. "A Shell of Memory: The Cyprus Conflict and Nicosia's Walled City." Memory Studies 5(4): 477-94. 
- 2012b. "The Legacy of Ottoman Building in Nicosia: Hans as Spaces of Coexistence in Pre-conflict Cyprus." International Journal of Islamic Architecture 1(1): 109-30.

- 2014. "Urban Form and Memory Discourses: Spatial Practices in Contested Cities." Journal of Urban Design 19(4): 36-57.

Baybars, Taner. 1970. Plucked in a Far-Off Land: Images in Self-Biography. London: Victor Gollancz Ltd.

Calabi, Donatella. 2004. The Market and the City: Square, Street and Architecture in Early Modern Europe. Aldershot: Ashgate.

Christofi, Emilia. 2010. "The Haunting Silence in the Heart of a City." Cyprus Mail, 25 April 2010, 8-9.

Cosgrove, Denis. 1986. Geography and Vision: Seeing, Imagining and Representing the World. London: I.B. Tauris.

Gilson Miller, Susan, and Mauro Bertagnin, eds. 2010. The Architecture and Memory of the Minority Quarter in the Muslim Mediterranean City. Cambridge, MA: Harvard University Graduate School of Design.

Halbwachs, Maurice. 1992. On Collective Memory, ed. Lewis A. Coser. Chicago: University of Chicago Press.

Hocknell, Peter. 2001. Boundaries of Cooperation: Cyprus De Facto Partition, and the Delimitation of Transboundary Resource Management. The Hague: Kluwer Law International.

Kyrris, Costas P. 1977. Peaceful Co-Existence in Cyprus under British Rule (1878-1959) and after Independence: An Outline. Nicosia: Kosmos Press.

Loizos, Peter. 1977. "Argaki: The Uprooting of a Cypriot Village." In Cyprus Reviewed: The Result of a Seminar on the Cyprus Problem held in June 3-6 1976 by the Jus Cypri Association and the Coordinating Committee of Scientific and Cultural Organisations, ed. M. Attalides. Nicosia: Jus Cypri Association.

Marangou, Anna. 1995. Nicosia a Special Capital. Nicosia: The Leventis Municipal Museum.

Massey, Doreen. 2005. For Space. London: Sage Publications.

Mills, Amy. 2010. Streets of Memory: Landscape, Tolerance, and National Identity in Istanbul. Athens: The University of Georgia Press.

Papadakis, Yiannis. 2005. Echoes from the Dead Zone: Across the Cyprus Divide. London: I.B. Tauris.

Papadakis, Yiannis. 2008. History Education in Divided Cyprus: A Comparison of Greek Cypriot and Turkish Cypriot Schoolbooks on the 'History of Cyprus.' Nicosia: PRIO Cyprus Center.

Pattie, Susan P. 1997. Faith in History: Armenians Rebuilding Community. London: Smithsonian Institution Press.

Simmel, Georg. 1950. The Sociology of George Simmel, trans. Kurt Wolff. New York: Free Press.

Trigg, Dylan. 2006. The Aesthetics of Decay: Nothingness, Nostalgia and the Absence of Reason. New York: Peter Lang. 


\section{Part II}

$\alpha \cdot\}$

Performing Coexistence and Difference 

a. Chapter $5 \cdot 6$

\title{
In Bed Together
}

\section{Coexistence in Togo Mizrahi's Alexandria Films}

\section{DEBORAH A. STARR}

\begin{abstract}
$\mathrm{T}_{\mathrm{b}}$
he camera pans across the rooftops in a popular district of Alexandria. The image cuts to chickens feeding on one of the rooftops, then fades to the interior of the adjacent one-room apartment. An alarm clock rings, waking Chalom, a Jewish seller of lottery tickets. He quiets the alarm, leans over, and wakens his bedmate, 'Abdu, a Muslim butcher's assistant (figure 1). Thus opens al- ${ }^{c} I z z$ Bahdala [Mistreated By Affluence (1937)], a film written, directed, and produced by Togo Mizrahi (1901-1986), an Alexandrian Jew with Italian nationality. ${ }^{1}$

This image of a Jew and a Muslim in bed together functions as a point of departure for this essay's analysis of the construction of coexistence in Togo Mizrahi's films produced in his studio in Alexandria. I approach the phrase "in bed together" as not just a metaphor of coexistence, but as a key to unlocking Mizrahi's projection of sameness and difference, self and Other, in 1930s Alexandria.

From the outset I should note that the sight of these two impoverished characters sharing a bed need not-and indeed should not-be understood as signaling sexual desire or a romantic affiliation between them. They share a bed because they are poor, not because they are gay. However, in this essay I argue that Togo Mizrahi's Alexandria comedies queer gender identity in a variety of ways, and that we cannot dismiss out of hand the gender and sexuality implications of this opening scene. ${ }^{2}$ In this essay I tease out the interrelationship in Togo Mizrahi's films between an ethics of coexistence, "Chalom and 'Abdu," and the queering of gender identity, "in bed together," as they play out against the backdrop of the cosmopolitan city of Alexandria. I argue that Mizrahi's films, through their narratives of mistaken identity, queer both ethno-religious identities and gender.
\end{abstract}




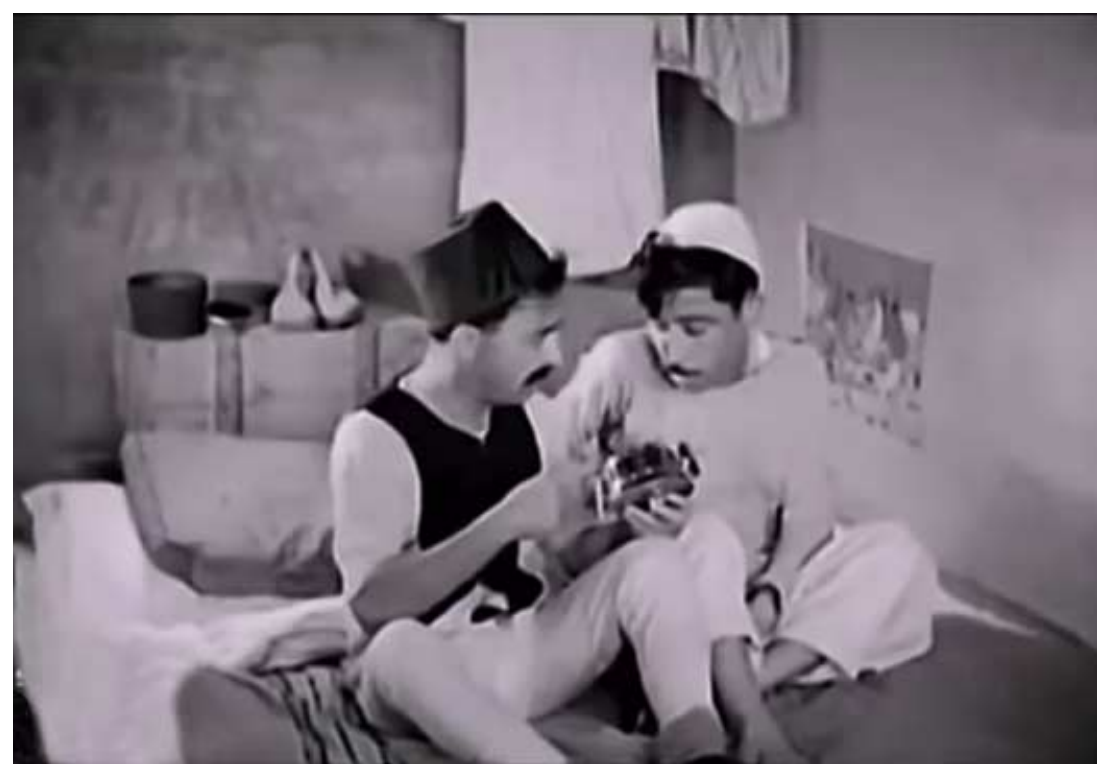

Figure 5.1. Chalom and ${ }^{\mathrm{c}} \mathrm{Abdu}$ wake up together in bed. Screenshot, Mistreated by Affluence (1937).

I begin my analysis by situating Mizrahi's Alexandria films within the development and critical reception of Egyptian cinema. Mizrahi's comedies-and 1930s and 1940s Egyptian films in general-while popular at the time of release, have been disparaged by latter-day nationalist film critics and historians. In the first section below, I argue that the coexistence narrative in Mizrahi's Alexandria films-as articulated through what I have termed a "Levantine cinematic idiom" - does not fit into the parochial nationalist paradigm of the critics, and goes at least part of the way toward explaining their discomfort with his films. In the second section I unpack the twin critical frameworks through which I analyze Mizrahi's films: queerness and the Levantine. In the final sections I flesh out this argument with readings of two of Mizrahi's Alexandria comedies: al-Duktur Farhat [Doctor Farahat (1935)] and Mistreated by Affluence. ${ }^{3}$

\section{Levantine Farce Versus National Melodrama}

Togo Mizrahi was one of the pioneers of the Egyptian film industry. Through the 1920s until the mid-1930s, filmmaking was driven by the creative efforts (and financial investments) of individuals-there was no 
Egyptian equivalent to the Hollywood studio system. In 1929 Mizrahi established his own film studio in Alexandria and his own production company Shirkat al-aflam al-misriyya (Egyptian Films Company). Studio Mizrahi produced more films in the 1930s than any other studio in Egypt (El-Shammaa 2007). Mizrahi directed and produced his films, developed the scenarios, and for the most part, throughout his career wrote (or co-wrote) his scripts. The first three films that Togo Mizrahi made in his Alexandria studio addressed social issues: al-Hawiya / al-Kukayin [The Abyss or Cocaine (silent, 1930)]; 5001 (silent, 1932); and Awlad Misr [Children of Egypt (sound, 1933)]..$^{5}$ Between 1934 and 1938 Mizrahi made nine Arabic comedies filmed in Alexandria and its environs and in his Alexandria studio. ${ }^{6}$

In 1939 Mizrahi began filming in Cairo, first shooting on the sound stage at Studio Wahbi, and then opening a second location for his own studio. ${ }^{7}$ His decision to begin filming in Cairo was likely due to the centralization of talent and resources in the capital at that time. In 1934, Egyptian nationalist financier Muhammad Tal' at Harb had founded Studio Misr, with the goal of establishing a robust national film industry. Harb also supported the development of local talent, investing in sending Egyptians for technical training in Europe (al-Hadari 2007; Hasan 1986). Studio Misr's first film, Widad, a musical starring the already well-known singer, Umm Kulthum, was released in $1936 .{ }^{8}$

The comedies Mizrahi directed between 1934 and 1938 in Alexandria share a number of features that distinguish them from his films made after his 1939 move to Cairo. The Alexandria comedies are all set in Egypt of the 1930s and involve a plot of mistaken identity. These films also all feature the same three comic stars who play consistent characters or types across the films: Chalom; 'Ali al-Kassar; and Fawzi al-Jazayirli. Leon Angel, the actor credited as Chalom, regularly appears as a charac-

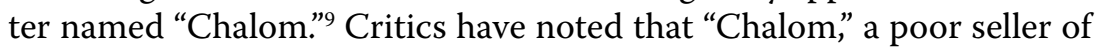
lottery tickets in a popular district of Alexandria, is modeled on Charlie Chaplin's tramp (Farid 1996). ${ }^{10}$ During the period under discussion Chalom appeared in two films directed by Mizrahi. 'Ali al-Kassar regularly appeared on stage and screen as a character called ${ }^{\mathrm{C}} \mathrm{Usman}{ }^{\mathrm{C}} \mathrm{Abd}$ al-Basit, a down-on-his-luck Nubian. ${ }^{11}$ Fawzi al-Jazayirli frequently played the shop owner "Bahbah," as well as a variety of other simple characters of limited means. ${ }^{12}$ In Mizrahi's films, al-Jazayirli's characters get themselves into complicated situations beyond their comprehension.

These films also all play out in the streets, cafes, shops, homes, clinics, and, of course, beaches of Alexandria. Alexandria has a long-standing reputation as a cosmopolis. Mizrahi's representation of the city in these films reflects Alexandria's diversity. Mizrahi's films from this era repre- 
sent a culture of coexistence that cuts across class. ${ }^{13}$ Mizrahi's choice of stars-Chalom plays a Jewish character; ${ }^{\mathrm{c}} \mathrm{Ali}$ al-Kassar portrays a Nubian-reflects an inclusive vision of local subjectivity. Mizrahi's films from this period regularly feature Greek and shami [Levantine Arab] characters as well as members of the Francophone Alexandrian elite.

While there is no abrupt rupture between Mizrahi's films before and after the relocation of his studio in 1939, some differences are notable. After 1939 Mizrahi continued to write and direct comedies of mistaken identity; however, he also began to explore other genres. The first film he made in Cairo, Fi Layla Mumtira [On a Rainy Night (1939)], is a musical melodrama. ${ }^{14}$ In the 1940s Mizrahi began to branch out into what could be called costume comedies, like the films starring ${ }^{\mathrm{c}} \mathrm{Ali}$ al-Kassar based loosely on narratives from the Thousand and One Nights: Alf Layla wa-Layla [1001 Nights (1940)]; and 'Ali Baba wa-l-Arbacin Harami [Ali Baba and the Forty Thieves (1942)]. Also, in Mizrahi's films after 1939 the self-conscious engagement with an ethics of inclusion becomes somewhat more muted, whether by virtue of generic conventions in the case of musicals, or the removal of comedies-which had already maintained a strained relationship to reality-from the Egypt of the time and into fictional settings.

Contemporaneous Egyptian critics lauded Mizrahi's efforts to bring locally produced entertainment to Egyptian viewers. One critic, Ra'uf Muhammad al-Shaf ${ }^{c}$ i (1935), deemed Doctor Farahat "a brilliant success ... in step with the Egyptian spirit." During these early years, critics also lavished praise on the performance of Mizrahi's stars. Muhammad Yunis al-Qadi (1935), a playwright who had written for Fawzi al-Jazayirli, expressed his appreciation for Mizrahi's adaptation of the actor's physical comedy for the screen. Another critic (Kutah 1935) lauded the screen presence of Tahiya Muhammad, later known by the screen name Tahiya Carioca, in her film debut under Mizrahi's direction in Doctor Farahat. ${ }^{15}$

Later Egyptian critics do not generally share this enthusiasm about Mizrahi's films. In an essay published in 1996, 'Ali Abu Shadi (1996: 9192), for example, concedes that, "Mizrahi's films were very popular and successful at the box office, and they made their stars famous." However, he goes on to dismiss these films for their "contrived and exaggerated" plot lines and their low-brow humor. Abu Shadi (1996: 91-92) levied the following critique of Mizrahi's comic fare: "These films are light comedies, there is no character development, no motivation for action, and no subtlety to the words. They seek only to amuse and entertain, and some are farces using mistaken identity and misunderstanding as their primary means of arousing laughs." 
Abu Shadi is correct that farces were indeed Mizrahi's stock in trade in the 1930s. The Concise Oxford Companion to the Theater defines farce as a "form of popular comedy in which laughter is raised by horseplay and bodily assault in contrived and highly improbable situations ... It deals with the inherent stupidity of man at odds with his environment" (Hartnoll and Found 1996). In its modern usage, according to the entry, "the word farce is applied to a full-length play dealing with some absurd situation, generally based on extra-marital adventures-hence "bedroom farce" (Hartnoll and Found 1996). However, the entry draws a clear distinction between farce with "its hold on humanity" and burlesque "depicting the grosser faults of mankind" (Hartnoll and Found 1996). Abu Shadi and other Egyptian critics are not alone in disparaging the contrivances of farce. ${ }^{16}$ Eric Bentley (1964: 219-56), in his analysis of the genre, cites a host of oppositions to the underpinning violence of farce, and its subversion of the tenets of religion, marriage, and moral social codes.

Mizrahi's farcical plots of mistaken identity are indeed "contrived" and "highly improbable." In this article I aim to make a case for the value of revisiting these farces (which I, apparently unlike Abu Shadi, find quite entertaining). What interests me is the nature of the contrivances of Mizrahi's farcical plots. Specifically, I wish to unpack the particular acts of "mistaken identity and misunderstanding" that Abu Shadi dismisses.

Abu Shadi's assessment also reflects a predominant trend in Egyptian film criticism. Critics sympathetic to Nasserist ideology take a dim view of interwar and postwar genre films, dismissing them as decadent and derivative of (dangerous) foreign influences (Flibbert 2005: 461n3). ${ }^{17}$ Nationalist critics of Egyptian film have tended to view melodrama as the vehicle best suited to cinema of substance. Melodrama has the capacity to reveal social ills. It was also the genre of choice for depicting the anti-colonial struggle. ${ }^{18}$

To summarize this position, nationalist critics have posited a relationship between the genre of melodrama and the nation (with emphasis here on the post-Nasser Arabo-centric nation). In this chapter, I similarly posit a relationship between the genre of farce and the Levantine. The Levantine idiom in Togo Mizrahi's 1930s farcical films, I am arguing, queers identity. ${ }^{19}$ It is this dynamic, more than the mere inclusion on screen of non-Arab minorities that challenges the hegemonic national narrative of Egyptian film criticism. As articulations of a queer, Levantine urban localism, Mizrahi's farces offer an alternative to the parochial, homosocial, and heteronormative national imaginary produced by and reproduced in melodrama. ${ }^{20}$ 


\section{Queerness and the Levantine}

My construction of the performativity of identities-Levantine, on the one hand, and gender and sexuality on the other-is indebted to Judith Butler's influential work, Gender Trouble (Butler 1990). Since her debunking of the myth of compulsory heterosexuality and stable categories of gender, the epistemological questions about identity that Butler raises burst open interrogation of other forms of identity formation. Richard Thompson Ford (2011: 123), for example, models his own critique of racial identity politics on Butler's critique of gender: "Queer theory's anti-identitarianism is the key to its portability ... The queer critique of (nominally) gay identity politics would seem to apply to identity politics in general." In labeling Mizrahi's Levantine film idiom "queer" I am referring to both the particularities of the performativity of gender and sexuality, as well as its broader destabilizing potential, as explored by Ford, for "identity politics in general."11

In the introduction to Out Takes, a volume of essays on queer theory and film, Ellis Hanson takes a similarly broad view of the term's significance. Hanson (1999: 4) defines "queer" as:

a rejection of the compulsory heterosexual code of masculine men desiring feminine women, and it declares that the vast range of stigmatized sexualities and gender identifications, far from being marginal, are central to the construction of modern subjectivity; but it is also, as Michael Warner has pointed out, a resistance to normalization as conceived more generally as a sort of divide-and-conquer mentality by which cultural difference-racial, ethnic, sexual, socioeconomic-is pathologized and atomized as disparate forms of deviance.

Hanson acknowledges the broad significance of the term queer, in destabilizing received categories including but not limited to gender and sexuality. In the second half of the quote, he asserts the power of queer theory to expose the dynamics of other forms of social marginalization.

I argue that Mizrahi's Alexandrian bedroom farces destabilize prevailing gender categories in 1930s Egypt. The films, by extension, poke fun at emerging middle class assumptions about modernity and the nation. Historian Wilson Jacob (2011) has mapped what he terms "effendi masculinity" - a subject position reflecting middle class aspirations toward and performance of modernity that began emerging in the last decades of the nineteenth century. This "effendi masculinity" was commonly recognizable by the 1930s. Jacob reads as performance these new forms of gendered, national subjectivity that emerge in British colonial Egypt. 
Mizrahi's 1930s comedies feature lower class characters ill at ease with middle class expectations. The bumbling characters portrayed by Chalom, 'Ali al-Kassar, and Fawzi al-Jazayirli simultaneously confront modernity and emerging gender norms to which they do not conform. Class mobility is linked in these films with the performance of normativized gender expectations that look a lot like the "effendi masculinity" Jacob identifies. The lens provided by Jacob permits us to see the ways, by extension, Mizrahi's films reflect upon and subtly critique (in a non-ideological way) emerging normativizing discourse and Egyptian articulations of modernity. ${ }^{22}$

According to Gershoni and Jankowski (1995), the new effendiyya were also the driving force behind a shift in the conception of the nation Egypt underwent in the 1930s that ran counter to Mizrahi's Levantine construction of identity, and threatened the coexistence of Jews and Muslims portrayed in his films. The territorial nationalism identified with the 1919 revolution, with its pluralist bent, had derived from Western thought and political philosophy. By the 1930s the economic and political environment had shifted, and disillusionment with the failures of the 1919 agenda fed the ascendance of what Gershoni and Jankowski (1995) call supra-Egyptian nationalism. Although these strains of nationalism shared an anti-colonial agenda, the supra-nationalists drew inspiration from Arab-Islamic sources and articulated their political agenda in terms shared by other Arabs and Muslims in contrast to the Western orientation of territorial nationalism. In practice, the ascendant nationalist strains increasingly excluded resident non-Muslim minorities like Mizrahi. The 1929 Nationality Law, according to Shimon Shamir (1987: 48), "gave dominance to jus sanguina" in defining those eligible for Egyptian nationality, and "accorded special position to Arab and/or Muslim affiliation." In the interwar period exclusionary nationalist discourses such as Greek irredentism, Italian fascism, and Zionism also circulated among some members of Egypt's resident foreign minority communities, dividing them from one another and from the majority culture.

Mizrahi's films resist this deterministic trend by embracing what I call a Levantine cinematic idiom. I have chosen the term "Levantine" because it reflects the 1930s Alexandrian society that Mizrahi portrays on screen, and in which he produced his films. The term "Levantine" also highlights ambiguity and performativity of identity alongside the presumption of diversity. I identify three characteristics of Mizrahi's Levantine idiom. First, Levantine films depict an urban localism characterized by diversity, and feature, to echo Rebecca Bryant's definition of "coexistence" in the introduction to this volume, "the horizontal relations among persons belonging to different ethnic or confessional groups." ${ }^{23}$ 
These films engage with, although do not necessarily promote, a Levantine ethics of coexistence. Second, these films also employ a visual language of inclusion, a Levantine aesthetic. Third, in these films the performance of identity is fluid and mutable, embracing the vagueness and porousness of the boundaries of identity. This idiom, which grows out of Egyptian comic theater, is evident in films by other filmmakers in Egypt in the 1930s as well. ${ }^{24}$

In what follows, I analyze two Togo Mizrahi films produced and set in Alexandria in the 1930s that engage the nexus between queerness and the Levantine: Doctor Farahat and Mistreated by Affluence. Doctor Farahat overtly troubles assumptions about gender and sexuality. Mistreated by Affluence, as I have already described above, foregrounds coexistence. By reading these films together, I aim to demonstrate how these two articulations of the performativity of identity in Mizrahi's work inform one another.

\section{Suitors in Swimsuits - Doctor Farahat (1935)}

Like Mizrahi's other films from this era, Doctor Farahat is fundamentally a comedy of assumed identity. Hilmy, a successful surgeon who has been living in England for fifteen years, returns to his native Alexandria to get married. In addition to his wealth, he is considered a minor celebrity for his medical discoveries. A match has been arranged to Nona, a woman he has not yet met. Concerned that she is a gold-digger, he seeks an opportunity to court her, without her knowing his identity. So, he arranges to meet her twice, once in disguise as the stuffy, bearded, and bespectacled Dr. Hilmy (figure 2), and once looking and acting naturally, but under the assumed identity of Mustafa, a clerk (figure 3 ).

To add to the confusion, upon Hilmy's arrival, he dodges reporters by asking an employee of the hotel, Farahat (Fawzi al-Jazayirli), to assume his identity. The backward, impoverished, and uneducated Farahat has been employed as a translator by the hotel under false (and humorous) pretenses. Nevertheless, the ruse succeeds; the reporters snap Farahat's picture, convinced they have taken the photo of Dr. Hilmy, setting in motion this additional plot line of mistaken identity.

Nona's family, eager to meet the young suitor, send for Hilmy, and instead get his geriatric pretender, Farahat. As the title suggests, it is Farahat's humorous misadventures in the guise of the esteemed Dr. Hilmy that dominate the plot. Farahat and his sidekick ${ }^{\mathrm{c}} \mathrm{Ali}$, in the role of the doctor's secretary, pay a visit to Nona's house. ${ }^{25}$ Nona and her friend Tahiya privately mock the suitor, and set out to humiliate him in the hopes of calling off the engagement. 


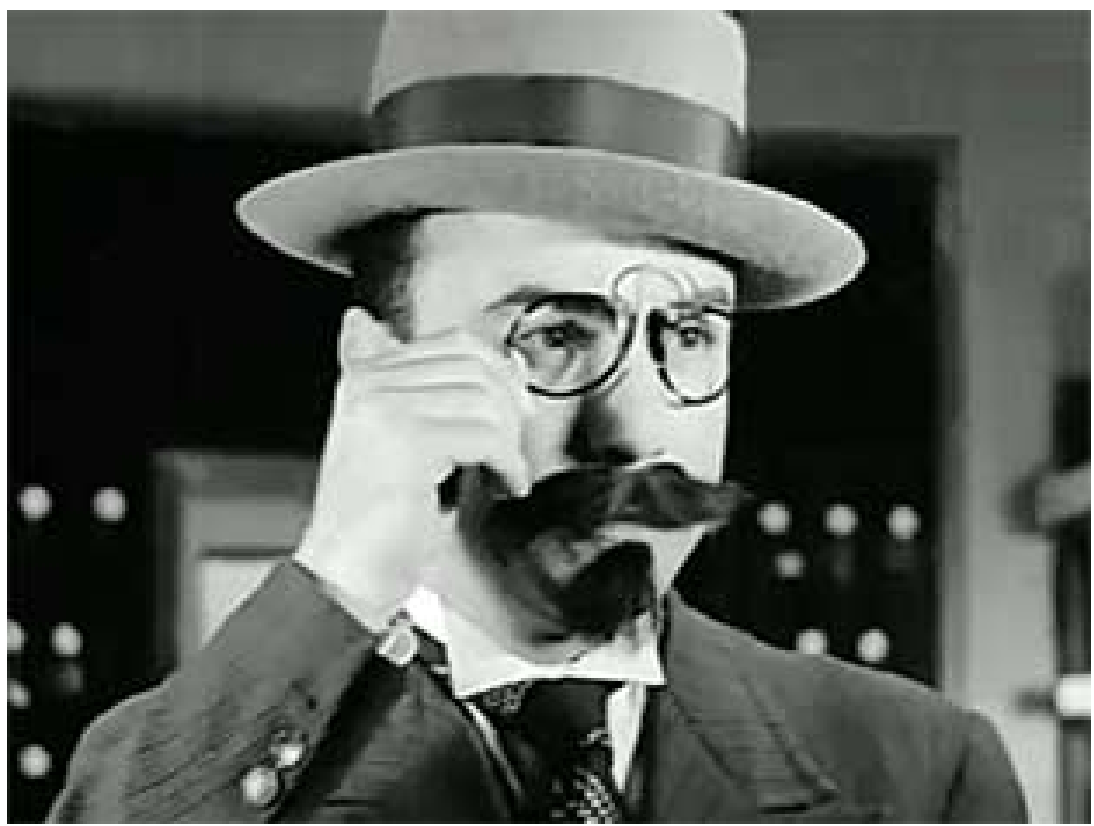

Figure 5.2. Hilmy disguised as Dr. Hilmy. Screenshot, Doctor Farahat (1935).

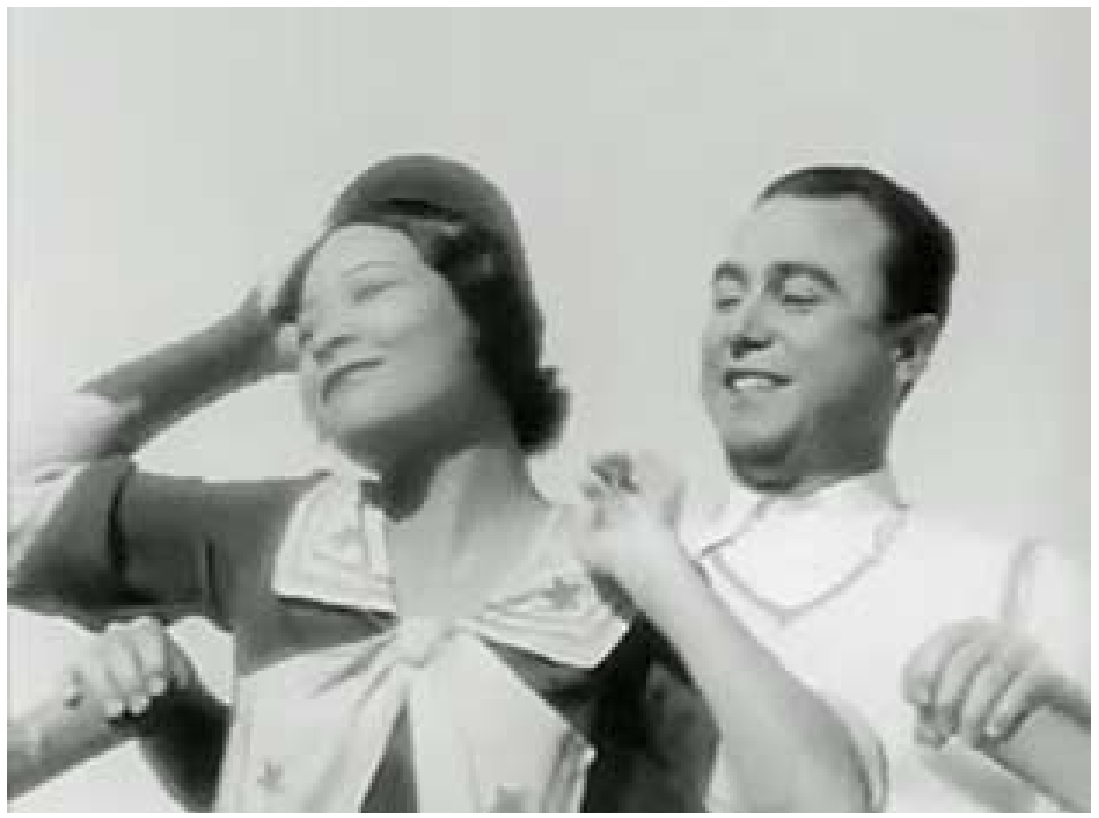

Figure 5.3. Hilmy disguised as Mustafa, with Nona. Screenshot, Doctor Farahat (1935). 
It is within this multilayered charade of mistaken identity that one encounters gender play. In what follows, I unpack two articulations of the queering of gender identity in Doctor Farahat. First, I examine instances when same sex pairs share the same bed. Then, I discuss moments in the film that individually and collectively can be read as highlighting a performative construction of gender identity.

Much of the plot of Doctor Farahat revolves around Nona's efforts to exhaust Farahat and to drive him away. The women first keep the men walking along the Corniche until midnight, then Nona calls at five o'clock the following morning to invite them for a swim. Nona also arranged for notable doctors to attend a lecture later the same morning to be given by "Dr. Hilmy" (Farahat), and in the afternoon she entices the men to join her for a party on a boat that lasts until late in the evening.

On four occasions, during the brief intervals between these engagements, Farahat and ${ }^{\mathrm{c}}$ Ali flop into the plush double bed in their shared hotel room. These comic scenes are rife with sight gags and tame verbal innuendo. On the first occasion, 'Ali removes his jacket on Farahat's side of the bed and starts to climb over Farahat. Farahat exclaims, "Hey brother, why not enter from the door of your house?" cAli responds, "But it's a long way from here. Let me pass through your roof." The root of the verb kharama, here used in its form that signifies "pass through" or "take a shortcut," can also signify "pierce"-adding to the suggestive double entendre to the exchange. Later in the scene, when the phone rings, ${ }^{\mathrm{c}} \mathrm{Ali}$, in his role as the esteemed doctor's secretary, again climbs over Farahat to answer the call (figure 4).

Although the men remain fully clothed, physical contact between them in bed-like the sight of ${ }^{\mathrm{c}}$ Ali climbing over Farahat-elicits laughs. ${ }^{26}$ By contrast with this scene, while the opening sequence of Mistreated by Affluence leaves no question that we are viewing a comedy, the fact that the two men share a bed is not played for laughs. Farahat and ${ }^{\mathrm{c}}$ Ali would, like their counterparts Chalom and ${ }^{\mathrm{c}} \mathrm{Abdu}$, think nothing of sharing a bed with a male friend in their own cramped domestic quarters. The luxurious bed in the hotel is large and inviting, and despite the presence of a couch in the suite, neither character seems to question that they would share the bed. Farahat objects to the way ${ }^{\mathrm{c}}$ Ali enters the bed, but not to his presence.

The scenes with Farahat and ${ }^{c}$ Ali confirm heteronormative sexuality within homosocial Egyptian norms. Any ambiguity of these bedroom scenes is resolved in the final iteration of this repeating pattern (figure 5). Throughout the film, Umm Ahmad, Farahat's wife, chases after him. After failing to follow him to the party on the boat, she lies in wait. After the party, Farahat falls drunk into bed and starts to brag about kissing Nona. Umm Ahmad indignantly reveals herself and demands an expla- 


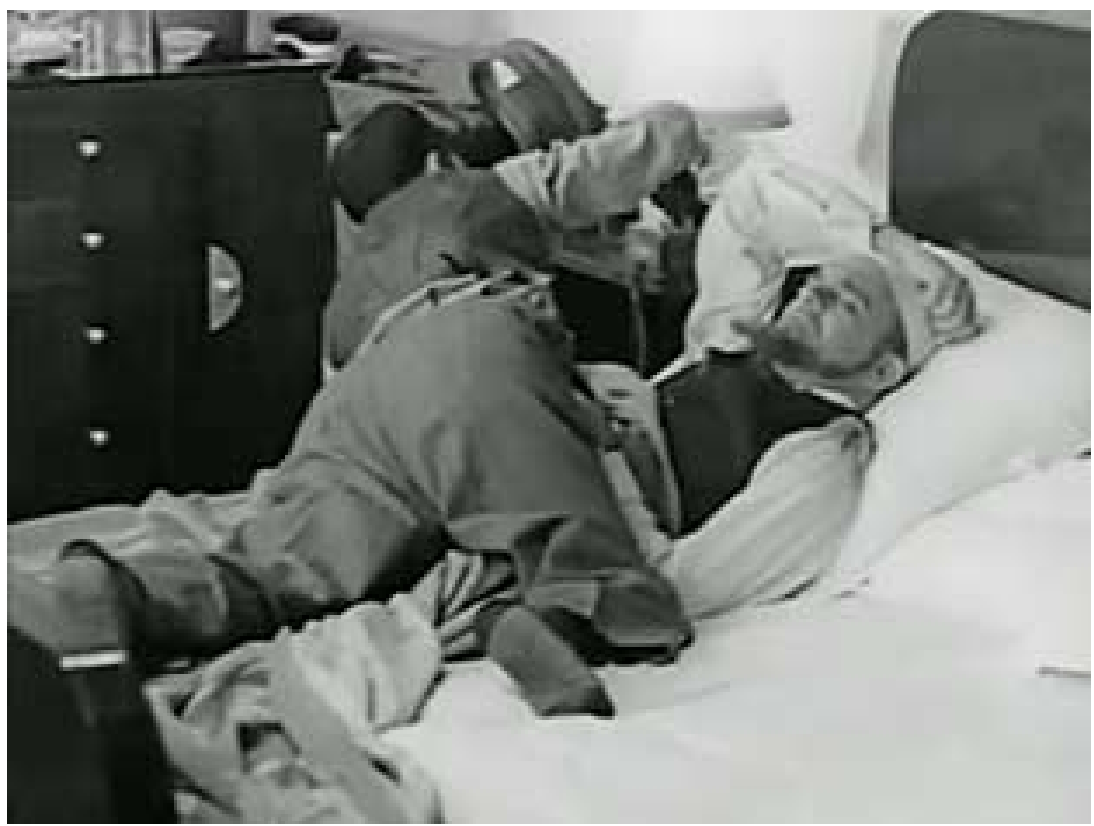

Figure 5.4. 'Ali climbs over Farahat to answer the telephone. Screenshot, Doctor Farahat, (1935).

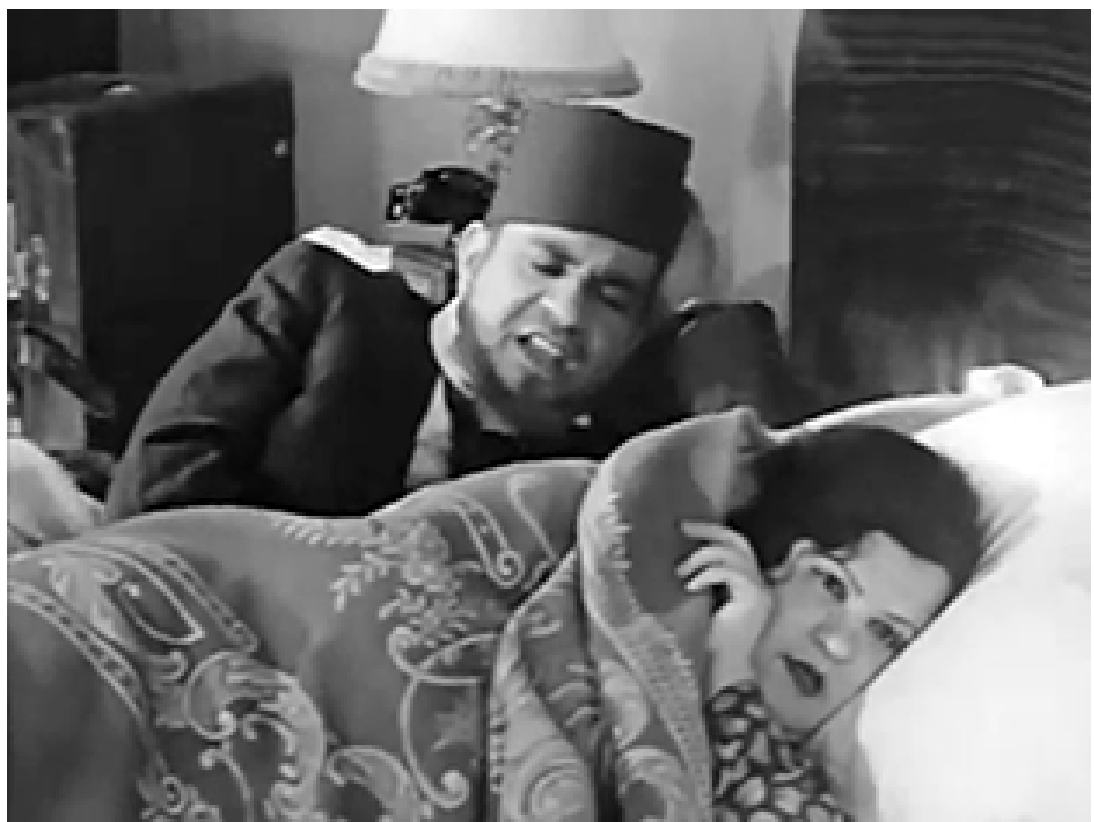

Figure 5.5. Farahat and Umm Ahmad in bed. Screenshot, Doctor Farahat (1935). 
nation. We are restored to the standard heteronormative extramarital love triangle of the bedroom farce.

Just prior to the first scene of Farahat and ${ }^{\mathrm{c}}$ Ali in bed together, Nona and Tahiya are also shown sharing a bed. After the long walk on the Corniche, Nona sits on the bed in a negligee, stretches, proclaims that she is tired and then lies down under the covers. Tahiya, sitting on the edge of the bed undressing, concurs, adding "If you think you're tired, what about them?" This scene reads as a (male) voyeuristic view into the women's boudoir.

Later, at the conclusion of the party scene, Nona and Mustafa embrace in the moonlight. The scene cuts abruptly to Nona's bedroom, the second scene showing the women in bed together. In this miniature scene, lasting nineteen seconds, Nona lies awake, and repeats Mustafa's proclamation of love to her, while Tahiya drifts off to sleep beside her (figure 6). The film then cuts to Umm Ahmad hiding under the covers awaiting Farahat's return from the party. As with the scene between Farahat and Umm Ahmad that follows, Nona's wakeful reflection appears to restore heteronormative desire. But, Nona muses on Mustafa's words-"I love you, Nona"-rather than giving voice to her own emotions (even in the privacy of her own bedroom). Unlike the conclusion of the scene between Farahat and Umm Ahmad, the self-reflexivity of Nona's utterance

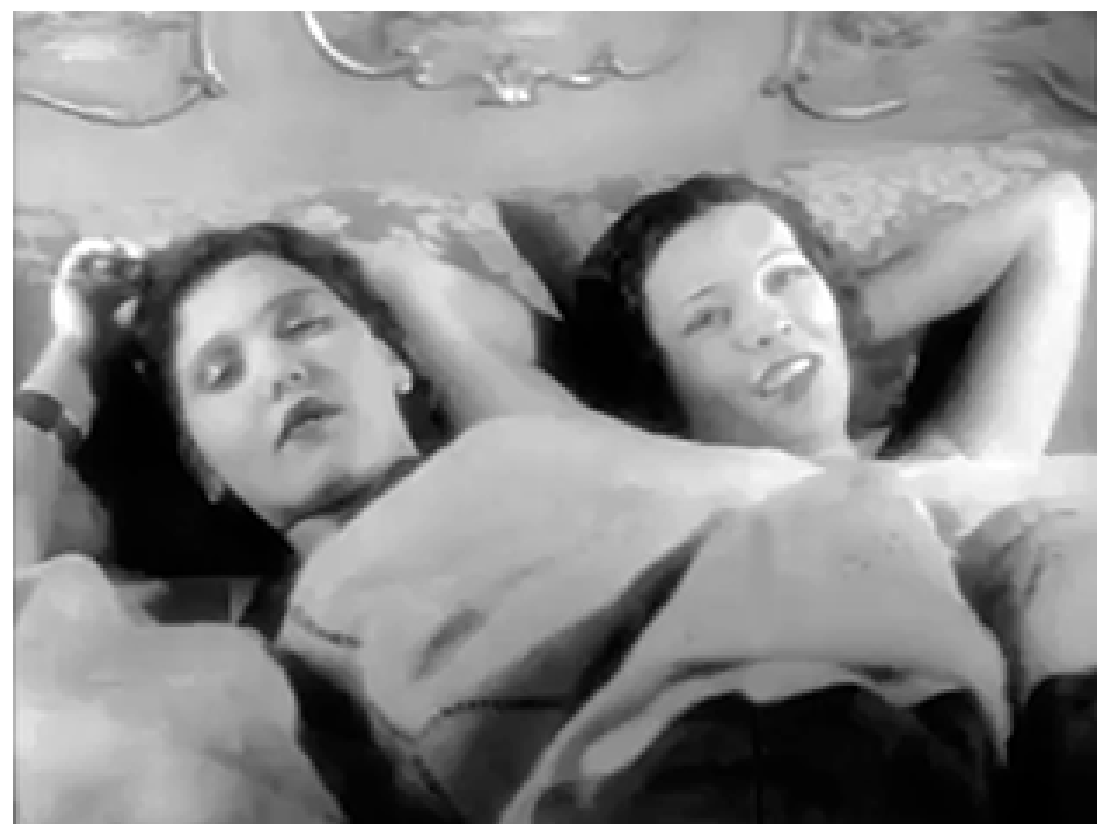

Figure 5.6. Nona and Tahiya in bed. Screenshot, Doctor Farahat (1935). 
simultaneously troubles the predominant narrative axis of heterosexual desire that it appears to assert. The ambivalence of Nona's assertion also fails to completely displace the titillating queerness of the visual projection of two scantily clad women in bed together.

As my reading of these bedroom scenes implies, Nona's role as an object of desire and as a desiring subject bears closer examination. Nona believes she has three male suitors in the film: Farahat, in the guise of Doctor Hilmy; Hilmy, in disguise as the stuffy doctor; and Hilmy as Mustafa. Male desire is focalized through the main character, Farahat. Viewers recognize that Farahat is a buffoon. His age and his coarse, uneducated, and lower-class manner make him appear an inappropriate suitor for the wealthy, modern, westernized Nona. We also know that Farahat is already married. ${ }^{27}$ While he inadvertently falls into the role of suitor, he persists in the charade for the promise of access to Nona's body. Each time Farahat considers walking away, Nona draws him back in by feigning affection and then, after the appearance of Mustafa, by fomenting jealousy.

Nona embraces her performance of femininity to deceive Farahat. Take, for example, the early morning swim. In the cabana with ${ }^{\mathrm{c}} \mathrm{Ali}$, Farahat decides that it is too cold to swim. He steps outside to inform Nona. Borrowing a visual idiom already established by Hollywood cinema, the camera reproduces Farahat's desirous gaze by panning Nona's body from toe to head. The sight of Nona in her bathing costume changes Farahat's mind.

But, the bathing scene that follows troubles these very same gendered assumptions about agency and desire. As she is changing into her bathing suit, an exasperated Nona proclaims that perhaps the women should "drown [the men] and be done with them." Tahiya, it appears, takes Nona's suggestion seriously. A lengthy silent montage (accompanied by upbeat music) intercuts Tahiya wrestling with ${ }^{\mathrm{c}} \mathrm{Ali}$ and Nona attempting to coax Farahat into the water. As the scene progresses, Tahiya's malicious intent becomes more apparent with each subsequent dunking. What is striking about this scene is its violence-violence perpetrated by the female characters. ${ }^{28}$ Tahiya's physical contact with ${ }^{\mathrm{c}}$ Ali in the water is simultaneously ludic and menacing, playful dunking that verges on attempted drowning. In the final image of the scene, Nona is shown dragging Farahat screaming into the cold water. This is torture, not play. Thanatos, not eros.

In the swimming scene the male characters are emasculated by an aggressive, predatory, violent femininity. And, over the course of the film, Nona's cruel tricks become increasingly more emasculating. The final indignity involves Nona piloting a small plane with Farahat as a passenger. Nona's aerial acrobatics frighten Farahat, causing him to wet his 
pants, and then pass out. It is worth recalling that this violence and cruelty is in the service of repelling a prospective suitor, deferring marriage.

Tahiya encourages Nona in her sadistic yo-yo of attraction and repulsion toward Farahat. Her motives begin to emerge in the cabana as the two women change into their swim suits. As Nona begins to unbutton her shirt, Tahiya casts her own desirous gaze at her friend's body. Farahat, it seems, is not the only one to leer at Nona's body. Nona is not only the object of the male gaze within the film (and for that matter, the object of the masculine gaze of the audience), she is also the object of a desirous female gaze. ${ }^{29}$ Tahiya's desire for Nona poses a complication (but not a replacement) of the heteronormative reading of the women's bedroom scenes.

Nona appears oblivious to Tahiya's affections. And, as the plots of mistaken identity unravel, we encounter a final (but not complete) restoration of heteronormativity. After Farahat passes out on the plane, the real Dr. Hilmy revives him. Hilmy and Farahat reveal their true identities. Hilmy requests Nona's hand in marriage from her puzzled parents. Nona's parents agree, although they admit they do not understand what has happened. When Tahiya bows out, she too, expresses her confusion. After dodging marriage for the whole film, Nona agrees to wed. Nona

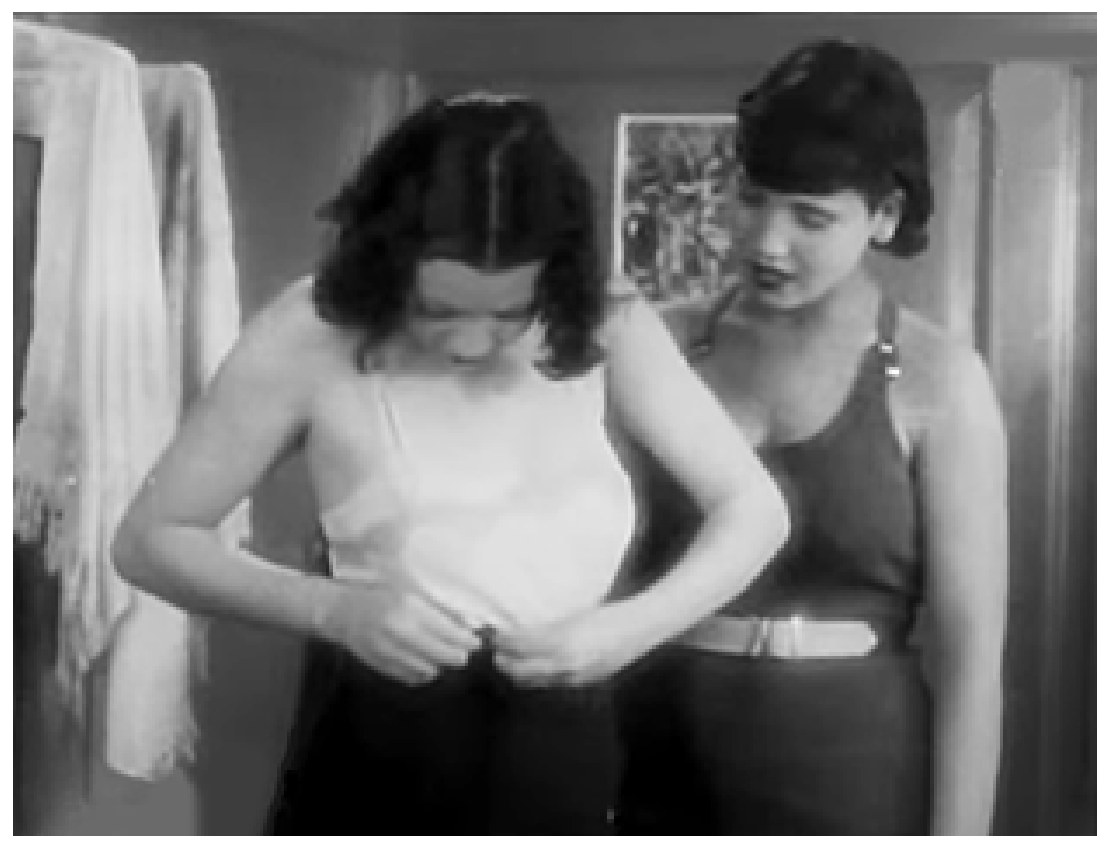

Figure 5.7. Tahiya watches Nona undress. Screenshot, Doctor Farahat (1935). 
and Hilmy embrace, as do the happily reunited Farahat and Umm Ahmad. Tahiya, however, is not paired off at the end of the film, despite the presence of a suitable male mate-Hilmy's friend. While her designs on Nona are thwarted, her same-sex desire is not normativized.

While I grant that this film narrates an especially convoluted plot, even for a farce, it is unusual for the characters in Mizrahi's films to remain confused once all has been revealed. The boundaries of identityand gender-have been troubled. The characters' confusion at the end of the film reflects the residual of the disturbances wrought by masquerade. We may end up with two male-female pairs, but the film does not conclusively or universally restore heteronormativity.

Thus far, I have focused my attention on masquerade as an articulation of gender instability in Doctor Farahat. I would also like to point to the way this film also marks fluidity of identity as Levantine. Hilmy first appears on screen in a disguise, insisting on embracing the fluid possibilities afforded by Levantine subjectivity. He counts on names as a signifier of an ethno-religious affiliation just as he relies upon the physical (and linguistic) indifferentiability of Levantines.

Dr. Hilmy makes his first appearance as he enters the hotel. In the first words he utters, Hilmy confirms with his secretary, ${ }^{\mathrm{c}} \mathrm{Ali}$, that a room has been booked. He continues: "Under what name?"

"Doctor Hilmy," replies 'Ali.

"You idiot," exclaims Hilmy, "Didn't we agree that you shouldn't register under the name 'Doctor Hilmy?"

"What should I have written?" retorts 'Ali.

"Write any name you want. Write 'Boutros.' Write 'Mikha'il."

In this originary moment, the masquerade that sets into motion the multiple layers of role play in the film, lies the (nominally) Muslim character's desire to hide behind a Christian name.

There is yet another layer to passing as a Levantine. The credits identify the actor playing Hilmy as ${ }^{\mathrm{c}} \mathrm{Abd}$ al-Aziz al-Mashriqi. This is a pseudonym. The actor playing Hilmy is none other than Togo Mizrahi. ${ }^{30}$ Mashriqi is the Arabic translation of the Hebrew Mizrahi (meaning "eastern," or, not to put too fine a point on it "oriental"). In other words, a Jewish actor (always already in disguise) plays a Muslim character, who seeks cover under a Christian name.

\section{A Parting Kiss - Mistreated by Affluence (1937)}

In Doctor Farahat the Levantine idiom I am mapping is articulated primarily through gender play as masquerade, with limited, but notable, 
articulations of an ethics of coexistence. Mistreated by Affluence inverts this formula, emphasizing coexistence over masquerade. As noted earlier, at the start of Mistreated by Affluence, the protagonists, Chalom and ${ }^{\mathrm{c}} \mathrm{Abdu}$ live together in a cramped room on the roof of an apartment building. ${ }^{31}$ The families of their respective fiancées, Esther and Amina, reside side by side in modest middle class apartments on the floor below. ${ }^{32}$ Although the families sleep in their separate quarters, they are frequently shown socializing in one another's apartments. This construction of domestic space, and the characters' actual or virtual cohabitation, serves as a microcosm for coexistence in the society at large.

Mistreated by Affluence is not about coexistence, though. The film neither interrogates nor problematizes difference. Nor does Mistreated by Affluence rely upon ethno-religious stereotypes as a source of comedy (Starr 2011). The narrative takes for granted that Jews and Muslims could be longstanding friends and neighbors in 1930s Egypt. This domiciled, or perhaps domesticated, coexistence serves as the solid foundation against which the film's contrived, farcical plot unfurls. Uncertainty lies beyond the confines of the domestic space and the quarter.

Buffeted along by chance, Chalom and ${ }^{\mathrm{c}} \mathrm{Abdu}$ bumble into (comical) situations beyond their control. ${ }^{\mathrm{C}} \mathrm{Abdu}$ is mistrusted, berated, and beaten by Hasan, the butcher for whom he works. But, when Hasan dies, he bequeaths the shop to his assistant. ${ }^{\mathrm{c}} \mathrm{Abdu}$ shares his newfound wealth with Chalom, enabling his friend to open a small shop from which to sell lottery tickets and exchange currency. The money also enables the men to get married after lengthy engagements. Following the weddings, Chalom purchases a bundle of scrap paper on behalf of his friend to use for wrapping meat. He discovers that the papers are stock certificates worth over 650,000 Egyptian pounds. Chalom insists on splitting the newfound wealth evenly with 'Abdu. They decide to purchase a bank, and settle into neighboring villas with their wives and in-laws. But the money sows discord, and the friends have an altercation. In the end, chance again prevails, the bank fails, and Chalom and ${ }^{\mathrm{c}} \mathrm{Abdu}$ lose their wealth. Chalom and ${ }^{\mathrm{c}} \mathrm{Abdu}$ reconcile, and they rejoice along with their families in the return to their homely coexistence.

The sharing of food and a shared food culture underpin the film's construction of coexistence between Jews and Muslims. ${ }^{33}$ The families are regularly depicted eating together in a series of scenes that intertwine the film's Levantine ethics and aesthetics. Near the beginning of Mistreated by Affluence, the two families prepare a picnic for Shamm al-Nasim-a spring festival celebrated by Egyptians of all religious affiliations. On the night before the festival, the women, Vittoria, Esther, Umm Amina, and Amina are shown packing food, while the men, Solomon and Ibrahim, 
play backgammon. Both families await the return of Chalom and ${ }^{\mathrm{c}} \mathrm{Abdu}$ who are charged with purchasing fisikh, the salted fish traditionally eaten on Shamm al-Nasim. The day of the festival is heralded by a lively montage of documentary footage shot in the streets, parks, and beaches of Alexandria, accompanied by a festive, non-diegetic soundtrack. Following shots of celebrants on the beaches of Alexandria, the scene cuts to a long shot in which we see Jewish and Muslim families crowded around covered crates, picnicking together in front of a bank of cabanas.

The scene is shot (in a studio) to give the impression of a busy beach during a popular festival. The wide-angle establishing shot of the group picnic offers an inclusive vision of cosmopolitan Alexandria. Several figures from a range of classes cross between the seated picnickers and the camera: a male bather; a police officer; a woman in bourgeois, Western attire holding a parasol; a fisherman carrying his gear. Two barefoot children sit cross-legged in the foreground eating, and in the background another man in a bathing suit engages in calisthenics. Even as the camera zooms in to a tighter group shot of the picnic, the scene retains its inclusiveness as the camera pans to show all eight characters eating and conversing.

This vision of coexistence is disrupted only by Vittoria's verbal abuse of her future son-in-law. The continuous take is broken by a cut to a close-up of Chalom asking about a dish not included in the feast. Vittoria berates him, and Chalom, gathering up loaves of bread, excuses himself and prepares to retreat, inviting Esther to join him. But, even in this moment of familial discord, a Levantine aesthetic persists. The camera pans from Chalom to Vittoria and back. Rather than shooting the argument in a shot-reverse-shot sequence of the two characters, the interaction is shot panning from one character to another, with other members of the group in view. This continuous, inclusive camerawork mirrors the content of this scene in which Jews and Muslims break bread together in celebration of a shared festival (Shafik 2007: 31).

Vittoria's condemnation of Chalom turns to praise after the families relocate to posh estates. The Jewish and Muslim families remain neighbors, residing in adjacent villas. The families continue to gather in their new homes and share meals together. But the pleasures of eating are denied to them just as they can finally afford expensive delicacies. In a comic subplot, two nurses, Maurice and Wali, pretending to be doctors, insinuate themselves on the families. They diagnose imaginary diseases so they can be paid for providing ongoing care. In the meantime, they sidle up to the young brides, hoping to woo them away from their husbands. Their "medical advice" consists primarily of manipulating access to food. 
In one scene, when Chalom and 'Abdu are delayed at the bank, the families begin dining in their absence under the doctors' vigilant eyes. The older generation is excoriated to abstain from anything but milk and boiled vegetables. The young women, by contrast, are plied with wine and rich foods. Like the picnic, the scene opens with a long establishing shot showing the families gathered together around a formal dining table. A servant enters carrying food to the table. But, the camerawork then mirrors the rupture between this dining experience and the former communal preparation and consumption of food; the dining room scene is constructed with a discontinuous series of two-shots, rather than the inclusive zoom and pan of the picnic scene.

In Mistreated by Affluence the masquerade is one of passing, involving Chalom and 'Abdu's (failed) efforts to act like members of the elite following their chance windfall. Their behavior is a comic exaggeration of the boorishness and ostentation of the nouveau riche. When they host a cocktail party for business associates, Chalom and ${ }^{\mathrm{c}} \mathrm{Abdu}$ wear lapel pins identifying themselves as the bank's directors. A bank manager charged with introducing the guests to the receiving line disdainfully flicks Chalom's pin and asks in a scornful voice, "What are you wearing? What is that? Take that thing off!" Chalom, puzzled, responds, "Why? Shouldn't people know that I am the director of the bank?" Gesturing toward "Abdu, he adds, "And him too?" The exasperated manager exclaims, "Director of the bank? Take it off! That is something janitors wear!" This misjudgment reflects the myriad missed codes and social cues of their adopted titles and assumed identities.

Chalom and 'Abdu take advantage of their newfound wealth and position of power to chase women. In the dalliance that renders Mistreated by Affluence a bedroom farce, Chalom and ${ }^{\mathrm{c}} \mathrm{Abdu}$ pursue the affections of a singer, Zuzu, and a dancer, Ruhiya. In contrast to Doctor Farahat, the heterosexual love triangle itself is the site of gender instability in Mistreated by Affluence.

Following their introduction at the nightclub where the women perform, Chalom and 'Abdu agree to a date at the women's apartment. Chalom and 'Abdu are cowed by the women's overt sexuality and forwardness. The viewer understands that these "artists" [artistat], are to be understood as loose women, if not downright prostitutes. ${ }^{34}$ Ruhiya beckons ${ }^{\mathrm{c}} \mathrm{Abdu}$ to enter her dressing room as she disrobes behind a shoulder-high barrier. While in this state of undress, she beckons ${ }^{\mathrm{c}} \mathrm{Abdu}$ to give her a kiss. Meanwhile, Chalom is instructed to enter the adjoining room where he finds Zuzu soaking in a tub. Covering his eyes as he approaches, Chalom hands Zuzu a bouquet of flowers. He crouches next to the tub and presents her with a bracelet, which he accidentally drops 
in the water. He pushes up his sleeve and reaches into the tub. Realizing what he has done, he runs out of the room, only to find that ${ }^{\mathrm{c}} \mathrm{Abdu}$ has also retreated. Chalom is rendered speechless, and resorts to gesturing and whistling to describe his interaction with Zuzu. ${ }^{35}$ The women's overt expression of sexual desire and, as in Doctor Farahat, predatory female sexuality poses an affront to the men's masculinity.

Chalom and ${ }^{c} \mathrm{Abdu}$ regroup and resolve to reassert their masculinity. ${ }^{\mathrm{C}} \mathrm{Abdu}$ steels himself to return to Ruhiya saying: "Listen Chalom, we need to be men. Ruhiya! I must speak to her. I must tell her that I love her. I must hold her. I must kill her with my kisses. Yes, I must!" [my emphasis]. Pushing Chalom out of the way 'Abdu warns, "Watch out!" and marches back toward Ruhiya's door. Thumping his chest Chalom concurs, "Yes! Men!" He attempts to repeat 'Abdu's rousing speech, but gives up when he is unable remember the exact words. Instead, Chalom tips his tarbush forward, puffs up his chest, and, as he dramatically prepares to march himself toward Zuzu's quarters, he says “Men! I will go! Watch out!"

The men, however, remain passive recipients of the women's affections. When Chalom enters Zuzu's boudoir, she is toweling her thighs, wearing only a bathrobe. She invites a nervous Chalom to kiss her, and he hesitantly responds with a chaste kiss on the top of her head. With further prompting, he kisses her on the cheek. Zuzu finally takes charge, throws herself into Chalom's arms and passionately embraces him. Likewise, after the encounter, a grinning ${ }^{c} \mathrm{Abdu}$ is shown with lipstick marks all over his face (but not on his lips). Although the camera does not follow 'Abdu's second encounter with Ruhiyya, the visible evidence also places him in a passive role.

Zuzu and Ruhiya's emasculating rhetoric sets into motion a sequence of events that devolve into a fight between Chalom and ${ }^{\mathrm{c}} \mathrm{Abdu}$ as they seek to reassert their masculinity. In the climactic party scene, Chalom and ${ }^{\mathrm{c}} \mathrm{Abdu}$ hide behind a curtain planning to surprise Zuzu and Ruhiya with bouquets of flowers. Instead, they overhear the women disparaging them. Ruhiya calls ${ }^{\mathrm{c}} \mathrm{Abdu}$ an oaf, but admits she likes the contents of his wallet. Zuzu casts aspersions on Chalom's virility, calling him a grasshopper, and likening his floppy mustache to a shrimp. She concludes with the kicker, "That half pint, you call that a man?"

From their hiding place, Chalom and ${ }^{\mathrm{c}} \mathrm{Abdu}$ also overhear the nurses Maurice and Wali professing their love to Esther and Amina. Impotent to respond to these insults on their own, Chalom and ${ }^{\mathrm{c}} \mathrm{Abdu}$ call for their in-laws to intervene. Following a chaotic shouting match, Maurice and Wali are escorted out of the party, but the protagonists are still smarting from the insults and spoiling for a fight. When Chalom overhears a guest 
claiming that he would be nothing without ${ }^{\mathrm{c}} \mathrm{Abdu}$, it is the last straw. Chalom pours out his wrath upon ${ }^{\mathrm{C}} \mathrm{Abdu}$, and his friend reciprocates. In the heat of the argument, each claims to have made "a man" out of the other.

Destabilized gender identity threatens to upset the narrative of coexistence. Esther's and Amina's families appeal to Chalom and 'Abdu to reconcile, urging the men not to let their fight undermine a thirty-year friendship between the families.

The emasculation of the bourgeois lifestyle and the threats it poses to coexistence are reversed only after Chalom and ${ }^{\mathrm{c}} \mathrm{Abdu}$ lose their wealth and the characters all return to their old residences. Likewise, at the end of the film, the equal access to communal food-along with the inclusive Levantine aesthetic-is restored. In the penultimate scene, the Jewish and Muslim families once again crowd around a table to share their favorite food together. As with the picnic, this scene is comprised of a single shot that includes all of the characters in the frame. The closing shot of the film also serves to reassert Chalom's virility. Chalom is shown returning to the street in the old neighborhood hawking lottery ticketsbut this time he is carrying infant twins.

By way of conclusion, I would like return to a brief scene that depicts the intersection of the two idioms of Levantine fluidity I have traced:

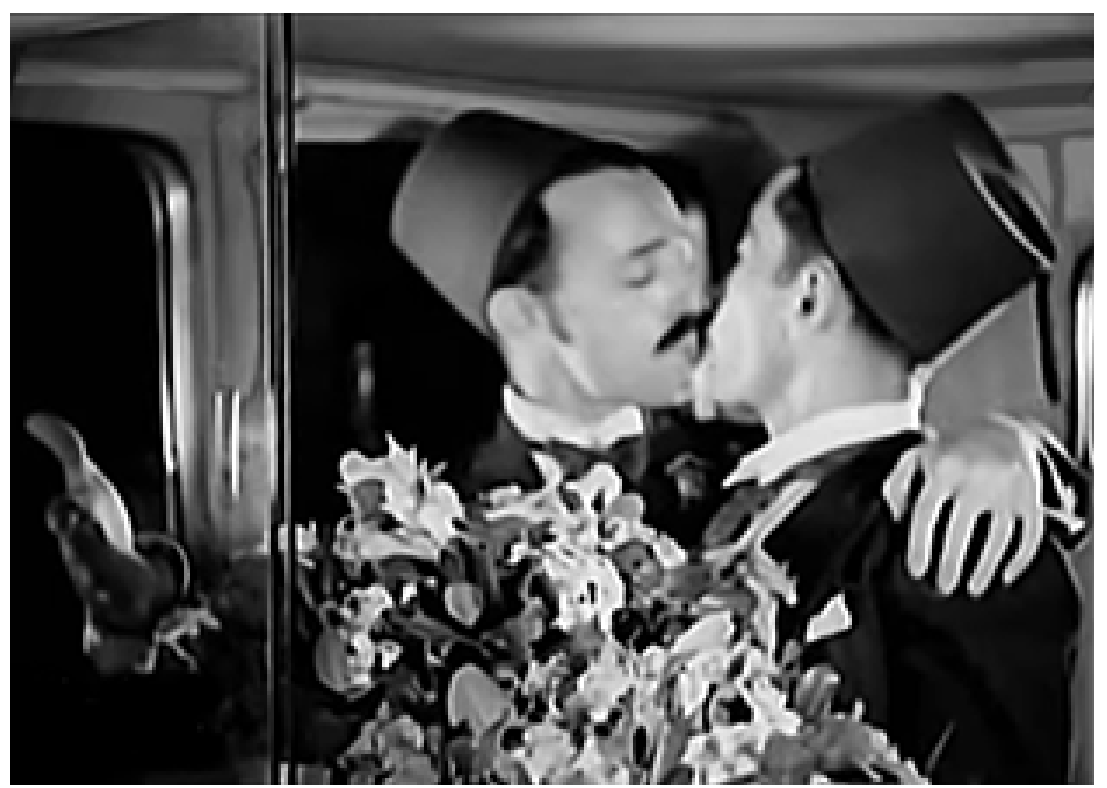

Figure 5.8. Chalom and ${ }^{\mathrm{c}} \mathrm{Abdu}$ kiss. Screenshot, Mistreated by Affluence (1937). 
communal, or ethno-religious identity on one hand; gender and sexuality on the other. On their way to their first encounter with their prospective mistresses, Chalom assuages 'Abdu's performance anxiety by offering him a tutorial on kissing. Holding up a bouquet of flowers, Chalom advises: "Say to her, 'take this present.' Say to her also, 'come here my love. ${ }^{36}$ And just like in the movies ..." Chalom then leans over and plants a kiss on ${ }^{\mathrm{C}}$ Abdu's lips.

For Mizrahi, it was not sufficient to draw laughs by depicting the two men kissing. The camera cuts to a second angle showing the driver observing the embrace in the rear view mirror (figure 9). The presence of a witness, an audience, signals the film's self-awareness of the act as a performance. The narratives of coexistence and the queering of identity evidenced in Mizrahi's films meet with the touch of Chalom and 'Abdu's lips.

Deborah Starr is Associate Professor of Modern Arabic and Hebrew Literature and Film in the Department of Near Eastern Studies at Cornell University. She is the author of Remembering Cosmopolitan Egypt: Literature, Culture, and Empire (Routledge, 2009) and co-editor, with Sasson Somekh, of Mongrels or Marvels: The Levantine Writings of Jacqueline Shohet Kahanoff (Stanford University Press, 2011). She also curated an open access digital archive of unpublished writings by Anglophone Coptic novelist Waguih Ghali. Her articles on various aspects

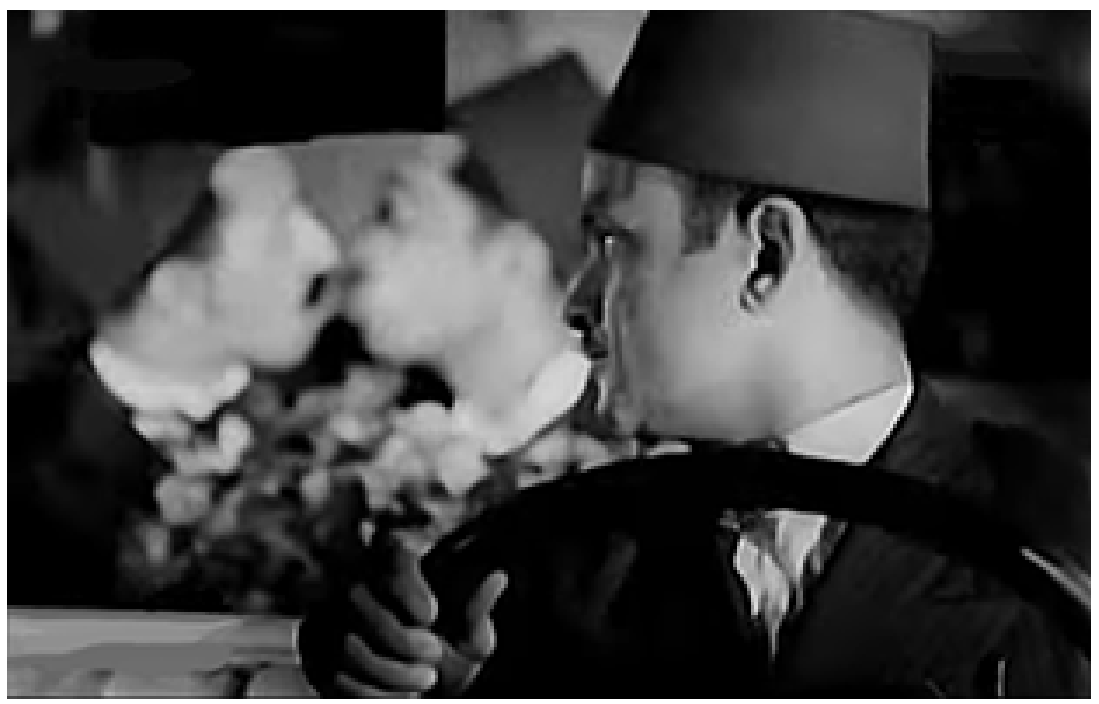

Figure 5.9. Driver watches Chalom and ${ }^{\mathrm{c}} \mathrm{Abdu}$ kiss. Screenshot, Mistreated by Affluence (1937). 
of Egyptian Jewish literature, as well as the cultural production of other Egyptian minorities have appeared in Prooftexts, Middle Eastern Literatures, and The Journal of Levantine Studies. This essay grows out of her current book project on the films of Togo Mizrahi.

\section{Notes}

I would like to thank the following people for their advice, comments, and support during the writing and revision of this article: Rebecca Bryant, Ziad Fahmy, Shai Ginsburg, Nick Salvato, Elliot Shapiro, Yaron Shemer, and Sara Warner. I am also grateful for the support of the Cornell Diversity Fellowship Seminar in 2013-14, and for the insightful comments of my fellow participants. I would also like to thank Amy Cheatle who helped capture and format the screenshots accompanying this chapter.

1. I have adopted Viola Shafik's (2007: 29) translation of the film's title from Arabic into English. The French title of the film at the time of its release was Les Deux Banquiers [The Two Bankers]. I am using a simplified version of the IJMES transliteration system; I use "c" for cayin and an apostrophe for hamza, but I have omitted diacritical marks. Upon first mention, I identify films by both their Arabic title and the title translated into English; on subsequent reference, I refer to films exclusively by their title in English.

2. My contention here is not unlike that made by Steven Cohan about the 1940s Bob Hope and Bing Crosby "Road to" movies, about which he writes: "I do not mean to propose that the 'Road to' films openly represent a gay sexual relation between the two male stars; but I am arguing that the comedic framework of the series plays upon intimations of homoeroticism, and that the queer shading of their buddy relation must be taken into account when understanding the immense popularity of Hope and Crosby's teaming in the 1940s" (Cohan 1999: 25).

3. I refer to the film in English as Doctor Farahat, rather than "Doctor Farhat," following the lead of Mizrahi's own romanization of the title into French in the credits as Le Docteur Farahat.

4. The film was released in Alexandria as al-Hawiya [The Abyss] and later screened in Cairo under the title al-Kukayin [Cocaine].

5. Little is known about 5001, and the film is unavailable. Ahmad al-Hadari does not include a plot summary in his entry on the film in his encyclopedic work on 1930s Egyptian cinema (al-Hadari 2007). The "Alex Cinema" website hosted by Bibliotheca Alexandrina offers the following synopsis: "By a stroke of luck Shalom wins lottery ticket number 5001 and becomes rich. Rather than bring him happiness, this wealth causes him trouble. He therefore goes back to his old way of life." ("Films Set or Filmed in Alexandria," Bibliotheca Alexandrina, http://www.bibalex.org/alexcinema/films/ Filmed_Alexandria.html.) This plot could either be played as comedy (as it is in Mistreated by Affluence) or as a drama. The editors at "Alex Cinema" 
mistakenly assume that the film is a drama that "tackle[s] social issues." ("Togo Mizrahi," Bibliotheca Alexandrina, http://www.bibalex.org/alexcin ema/cinematographers/Togo_Mizrahi.html.) Publicity around 5001 at the time of release identifies the film as a sports comedy.

6. During this four-year period Mizrahi also released a musical melodrama al-Bahhar [The Sailor (1935)]. I emphasize "Arabic films" because between 1937 and 1943 Mizrahi also directed four Greek-speaking films. Two of the films were Greek versions of his Arabic films Doctor Farahat [1935 Arabic; 1937 Greek], and The Sailor [1935 Arabic; 1943 Greek] ("Greek-Speaking Films," Bibliotheca Alexandrina, http://www.bibalex.org/alexcinema/films/ Greek.html).

7. Fi Layla Mumtira [On a Rainy Night], released on 9 March 1939, and Salafini 3 ginayh [Lend Me 3 Pounds], released on 28 September 1939, were shot at Studio Wahbi (al-Hadari 2007: 365-69).

8. For more on Umm Kulthum's career see Danielson (1997).

9. Chalom starred in three films directed by Togo Mizrahi: 5001; The Two Delegates; and Mistreated by Affluence.

10. Ahmad al-Hadari also cites the Egyptian actor Bishara Wakim as a source of influence on Chalom's acting style. Wakim had debuted a down-on-hisluck character on screen in a silent comedy shot in Alexandria, Barsum Yabhath ${ }^{c}$ an al-Wathifa [Barsum Looks for a Job (1925), directed by $\mathrm{Mu}-$ hammad Bayumi] (al-Hadari 2007: 255).

11. Al-Kassar starred in five films directed by Togo Mizrahi in his Alexandria studio: Miat alf ginayh [One Hundred Thousand Pounds (1936)], Khafir aldarak [The Watchman (1936)], al-Saca Sabca [Seven O'Clock (1937)], al-Tiligraf [The Telegraph (1938)], and ${ }^{c} U$ thman wa- ${ }^{c}$ Ali [ ${ }^{c}$ Usman and ${ }^{c}$ Ali (1939)].

12. In the 1930s Fawzi al-Jazayirli starred in two films directed by Mizrahi: Doctor Farahat and The Sailor. He also appeared in supporting role in The Two Delegates.

13. Most of the later nostalgia literature about cosmopolitan Alexandria, by contrast, largely represents the foreign-minority bourgeoisie; see Starr (2009). This phenomenon is not limited to Alexandria, as Anagnostopoulos notes in this volume: "The way scholars and laypeople approach and recreate images of peaceful coexistence in the Ottoman Empire is oftentimes markedly aestheticized by the heritage industry of today, especially in the context of cosmopolitan Mediterranean ports, and often prevents them from understanding the context of coexistence in the past" (p. 87).

14. Mizrahi's 1930 s sound comedies tend to include musical numbers. I have, however, chosen not to designate them as "musicals." Mizrahi's 1940s musical melodramas feature a singer in a starring role, whereas the stars in the 1930s Alexandria comedies are non-singing comic actors. While musical performance features in these films, it is beyond the scope of this chapter to engage in a sustained analysis of its significance.

15. All three 1935 reviews are cited in al-Hadari (2007: 169). Tahiya Carioca's given name was Badiya Muhammad 'Ali al-Nidani. In Doctor Farahat she is credited as Tahiya Muhammad. 
16. For example, there is a very small body of academic literature on the Victorian farce Charley's Aunt (1892), by Brandon Thomas, an enormously popular play with a record-breaking run on stage for its time, and multiple translations and adaptations - including a short Egyptian silent film in 1920 starring 'Ali al-Kassar, al-Khala al-Amrikiyya. By contrast, Oscar Wilde's The Importance of Being Earnest (1895), which is widely viewed as a subversion of the genre, has received extensive critical attention.

17. Flibbert lists several notable examples of this commonly accepted claim. Others, including Flibbert have drawn attention to the value for film critics and historians of films in these under-studied periods, and of critically under-appreciated popular genres such as musicals and comedies. This present study emerges out of engagement with this body of scholarship. Ahmad Yusuf, for example, debunks assumptions about "the cinema of war profiteers" of the 1940s, in Yusuf (1996). See also Armbrust (2000).

18. Joel Gordon's Revolutionary Melodrama maps the centrality of melodrama to the construction of national identity in the 1950s (Gordon 2002).

19. I am not suggesting that the terms I am using (or their equivalents, such as they might be, in Arabic, French, or Italian, etc.) would have had currency in 1930s Alexandria-neither among Egyptians nor the resident minorities and foreigners. Rather, the notions of "queerness" and "the Levantine" in tandem provide a language and critical framework for understanding and unpacking the significance of Mizrahi's fluid construction of identity in these films.

20. In the American literary and film vernacular in the same period, Dashiell Hammett's Joel Cairo offers a notable example of the slipperiness attributed to both the Levantine and to queerness (Hammett 1984). I am not suggesting that The Maltese Falcon (1929) nor its 1930s film adaptations [The Maltese Falcon, Roy Del Ruth, dir. (1931); Satan Met a Lady, William Dieterle, dir. (1936)] should be read as direct intertexts for Mizrahi's work. Rather, I wish to point out the parallel associations between queer and what I have termed "Levantine" identities in Mizrahi's films.

21. I do not assume in my analysis that queerness need align with progressive or radical politics. While Mizrahi's queer Levantine disrupts emerging parochial ethno-religious nationalisms in 1930s Egypt, his liberal, pluralist, ethics of coexistence could hardly be termed radical.

22. A film Togo Mizrahi produced, al-Riyadi [The Athlete (1937)], garners brief mention in Jacob's discussion of the place of sport and fitness in the emergence of effendi masculinity (Jacob 2011: 156). The film, starring Chalom, was directed by L. Nagel and Clément Mizrahi.

23. Bryant, "Introduction," p. 4.

24. For example, elsewhere I have examined Niyazi Mustafa's Salama fi khayr [Salama is Fine (1937)] as an articulation of this Levantine idiom (Starr 2011). Garay Menicucci (1998: 32) analyzes the homoerotic content of another contemporaneous film, Bint al-Basha al-Mudir [The Pasha Director's Daughter, Ahmad Galal, dir. (1938)], about a young woman who dresses as 
a man for purposes of employment, precipitating a love triangle where she becomes the object of both male and female desire. The Pasha Director's Daughter shares a fluidity of gender identities with Mizrahi's films from the 1930s.

25. The actor Ahmad al-Haddad also plays ${ }^{\mathrm{c}} \mathrm{Abdu}$ in Mistreated by Affluence.

26. Vito Russo (1987: 37) lists legions of examples from Hollywood cinema in the 1910s through the 1930s in which homoerotic innuendo between men was played comically. He also notes that the American press, which took issue with more directly subversive characters and plots, tended not to comment on "open signs of homosexuality in a comic context." The screenwriters of the documentary film based on Russo's book put it more succinctly: "In a hundred years of movies, homosexuality has only rarely been depicted on screen. When it did appear, it was there as something to laugh at, or something to pity, or even something to fear." The Celluloid Closet, Rob Epstein and Jeffrey Friedman, dir. (1995).

27. Although polygamy is permitted by Islam and remains legal in Egypt, it was not commonly practiced in Mizrahi's time (Kholoussy 2010: 83).

28. I am thinking here of Eric Bentley's (1964: 219-56) contention about the centrality of violence to farce, and the inherent dialectic within the genre between gentleness and violence. I would like to thank Nick Salvato for pointing me to this reference.

29. Little has been written about female same-sex desire in the Middle East and its representation in literature and film. Stephen Murray (1997) provides a very brief introduction to the topic in "Woman-Woman Love in Islamic Societies." Samar Habib's (2000) monograph Female Homosexuality in the Middle East offers the most extensive study of the topic, although her discussion skips from Medieval texts to late twentieth century, and her analysis of Arab film begins in the 1970s.

30. While writing and directing credits appeared in all of his films as "Togo Mizrahi," as an actor, he appeared under a pseudonym. Togo Mizrahi acted in two films under the name Ahmad al-Mashriqi: The Abyss / Cocaine and Awlad Misr [Children of Egypt (1933)]. An actor credited in those same two films as 'Abd al-'Aziz al-Mashriqi is believed to be Togo's brother. In Doctor Farahat, Togo Mizrahi, not his brother, is the actor credited as 'Abd al${ }^{\mathrm{c} A z i z}$ al-Mashriqi (al-Hadari 2007: 168). I would also like to thank Jacques Mizart, Togo Mizrahi's nephew, for confirming the identity of the actor.

31. In his 2002 novel ' Imarat Yacqubiyan (The Yacoubian Building), 'Ala alAswani $(2002 ; 2006)$ returns to roof-dwellers to reflect anew upon Egypt's multi-cultural past and its bearing on the present and future of Egyptian society. For analyses of the signification of the homosexual relationship between a resident of the building and a roof-dweller in The Yacoubian Building, see al-Samman (2008) and Hadeed (2013).

32. Mistreated by Affluence is the second of two films Mizrahi made about the friendship between Chalom and 'Abdu, Esther and Amina. The first was al-Manduban [The Two Delegates (1934). 
33. In the introduction to this volume, Rebecca Bryant offered shared meals as an example of commensality (p. 2). She notes that the invocation of such shared experiences points to their exceptionality, and to the pre-existence of notions of difference overcome by the shared practice. The shared meals in Mistreated by Affluence could be read in this way, too: the emerging forms of Arab-Islamic nationalism in 1930s Egypt threw into relief the differences between Muslims and Jews that Mizrahi's meal scenes seek to overcome.

34. For more on popular assumptions about this association in the Egyptian context, see Nieuwkerk (1995).

35. Chalom's expressive whistling in this scene is reminiscent of Harpo Marx. Mistreated by Affluence appears to borrow from and reference Marx Brothers' movies at other junctures as well.

36. The Arabic "tacali ya ruhi" plays on Ruhiya's name.

\section{References}

Abu Shadi, cA. 1996. "Genres in Egyptian Cinema." In Screens of Life: Critical Film Writing from the Arab World, ed. A. Arasoughly, 84-129. St-Hyacinthe, Quebec: World Heritage Press.

Armbrust, W. 2000. "The Golden Age before the Golden Age: Commercial Egyptian Cinema before the 1960s." In Mass Mediations New Approaches to Popular Culture in the Middle East and Beyond, ed. W. Armbrust, 292327. Berkeley: University of California Press.

Aswani, 'A, al-. 2002. 'Imarat Yacqubiyan. al-Qahira: Mirit lil-nashr wa-almaclumat.

- 2006. The Yacoubian Building. New York: Harper Perennial.

Bentley, E. 1964. The Life of the Drama. New York: Atheneum.

Butler, J. 1990. Gender Trouble : Feminism and the Subversion of Identity. New York: Routledge.

Cohan, S. 1999. "Queering the Deal: On the Road with Hope and Crosby." In Out Takes: Essays on Queer Theory and Film, ed. E. Hanson, 23-45. Durham, NC: Duke University Press.

El-Shammaa, M.M. 2007. Shadows of Contemporary Lives: Modernity, Culture, and National Identity in Egyptian Filmmaking. Ph.D. dissertation, University of California at Los Angeles.

"Farce." 1996. In The Concise Oxford Companion to the Theatre, ed. Phyllis Hartnoll and Peter Found. Oxford: Oxford University Press. http://www .oxfordreference.com/10.1093/acref/9780192825742.001.0001/acref-978 0192825742-e-1052.

Farid, S. 1996. "Periodization of Egyptian Cinema." In Screens of Life: Critical Film Writing from the Arab World, ed. A. Arasoughly, 1-18. St-Hyacinthe, Quebec: World Heritage Press.

"Films Set or Filmed in Alexandria." Bibliotheca Alexandrina, http://www.bib alex.org/alexcinema/films/Filmed_Alexandria.html. 
Flibbert, A. 2005. "State and Cinema in Pre-Revolutionary Egypt 1927-1952." In Re-Envisioning Egypt 1919-1952, ed. A. Goldschmidt, A. J. Johnson and B. A. Salmoni, 448-460. Cairo: American University in Cairo Press.

Ford, R.T. 2011. “What's Queer About Race?” In After Sex?: On Writing since Queer Theory, ed. J. Halley and A. Parker, 121-129. Durham, NC: Duke University Press.

Gershoni, I., and J. Jankowski. 1995. Redefining the Egyptian Nation, 1930-1945. Cambridge: Cambridge University Press.

Gordon, J. 2002. Revolutionary Melodrama: Popular Film and Civic Identity in Nasser's Egypt. Chicago: Middle East Documentation Center.

“Greek-Speaking Films." Bibliotheca Alexandrina, http://www.bibalex.org/alex cinema/films/Greek.html.

Habib, S. 2007. Female Homosexuality in the Middle East: Histories and Representations. New York: Routledge.

Hadari, A, al-. 2007. Tarikh al-Sinima fi Misr: Min Bidayat 1931 ila Akhir 1940. Cairo: al-hay'a al-misriyya al-cama li-l-kitab.

Hadeed, K. 2013. "Homosexuality and Epistemic Closure in Modern Arabic Literature." International Journal of Middle East Studies 45: 271-91.

Hammett, D. 1984. The Maltese Falcon. New York: Vintage Books.

Hanson, E. 1999. "Introduction." In Out Takes : Essays on Queer Theory and Film, ed. E. Hanson, 1-19. Durham, NC: Duke University Press.

Hartnoll, P., and P. Found, eds. 1996. "Farce." In The Concise Oxford Companion to the Theatre. 2 ed. Oxford: Oxford University Press.

Jacob, W.C. 2011. Working out Egypt: Effendi Masculinity and Subject Formation in Colonial Modernity, 1870-1940. Durham, NC: Duke University Press.

Kholoussy, H. 2010. For Better, for Worse: The Marriage Crisis That Made Modern Egypt. Stanford, CA: Stanford University Press.

Kutah, M. 1935. "Review of al-Duktur Farhat." Kawkab al-Sharq.

Menicucci, G. 1998. "Unlocking the Arab Celluloid Closet: Homosexuality in Egyptian Film." Middle East Report 206: 32-36.

Murray, S.O. 1997. "Woman-Woman Love in Islamic Societies." In Islamic Homosexualities: Culture, History, and Literature, ed. S.O. Murray and W. Roscoe, 97-104. New York: New York University Press.

Nieuwkerk, K.V. 1995. A Trade Like Any Other: Female Singers and Dancers in Egypt. Austin: University of Texas Press.

Qadi, M. Y, al-. 1935. "Review of al-Duktur Farhat." al-'Arusa, April 3.

Russo, V. 1987. The Celluloid Closet: Homosexuality in the Movies. New York: Harper \& Row.

Samman, H, al-. 2008. "Out of the Closet: Representation of Homosexuals and Lesbians in Modern Arabic Literature." Journal of Arabic Literature 39: 270-310.

Shafi, R. M., al-. 1935. "Review of al-Duktur Farhat." Kawkab al-Sharq, November 27.

Shafik, V. 2007. Popular Egyptian Cinema: Gender, Class, and Nation. Cairo: The American University in Cairo Press. 
Shamir, S. 1987. "The Evolution of the Egyptian Nationality Laws and Their Application to the Jews in the Monarchy Period." In The Jews of Egypt: A Mediterranean Society in Modern Times, ed. S. Shamir, 33-67. Boulder: Westview Press.

Starr, D. A. 2009. Remembering Cosmopolitan Egypt: Literature, Culture, and Empire. London: Routledge.

2011. "Masquerade and the Performance of National Imaginaries: Levantine Ethics, Aesthetics, and Identities in Egyptian Cinema." Journal of Levantine Studies 1: 31-57.

“Togo Mizrahi." Bibliotheca Alexandrina, http://www.bibalex.org/alexcinema/ cinematographers/Togo_Mizrahi.html.

Yusuf, A. 1996. "Safahat min Tarikh al-Sinima al-Misriyya." In Misr: Miat Sana Sinima, ed. A.R.F. Bahjat, 167-172. Cairo: Mihrajan al-Qahira al-Sinima'i al-Dawli al-'Ishrun. 
2. Chapter $6 \cdot 6$

\title{
Memory, Conviviality, and Coexistence
}

\author{
Negotiating Class Differences in Burgazadasl, Istanbul
}

\section{DENIZ NERIMAN DURU}

$\mathrm{I}_{\mathrm{n}}$ much of the literature on peace and conflict resolution in the Balkans, Southern Europe, and the Middle East, scholars attempt to analyze cultural plurality using the concept of coexistence. This is a coexistence that is being excavated from the ruins of conflict, with the idea that it may shed light on how people could live together again. Examples of such coexistence include that between Israelis and Palestinians; Greek and Turkish Cypriots; or Serbs, Croats, and Bosnians (e.g., Wallensteen 2007; Abu-Nimer 2001; Dayton and Kriesberg 2009; Phillips 1996; Anastasiou 2002; Gidron, Katz, and Hasenfeld 2002). This is the coexistence that Bryant, in her introduction, contrasts with "everyday coexistence" and notes "the legal, political, and discursive forms of coexistence that imply the 'living together' of millets or ethnic groups within the empire or nation" (Bryant this volume, p. 8).

This chapter represents a critical engagement with coexistence in the context of Turkey, where the idea of "living together" has been burdened with concepts of "toleration" inherited from the Ottoman past and inscribed in Republican law. Coexistence, with its connotations of different ethnic or religious groups living together, has no equivalent in Turkish. Rather, the most commonly used term to refer to the interaction of such groups is hoşgörü, literally "to see well" and usually translated as "tolerance." While I cannot engage here in all the connotations of the word and ways in which it may diverge from the primarily negative connotations of "toleration," it is a word that has been applied in the post-Ottoman Turkish context primarily to non-Muslim minorities whose status as minorities was secured by the Treaty of Lausanne. As 
Bryant notes in the introduction, this does not mean that there have not been concepts of everyday coexistence in operation, especially the idea of komşuluk and the mahalle. However, these ideas of living together have been problematically projected onto the scale of relations between ethnic and/or religious groups, blurring the scale that equates "the existence of certain neighborhoods where persons of different religions lived side by side, sharing the responsibilities of the mahalle, with the 'peaceful' existence of religious and ethnic minorities within the Empire" (Bryant this volume, p. 17).

To complicate matters further, this discourse of coexistence, with its blurring of scale, furthermore returns to have real impact on actual everyday coexistence in the present. For instance, in the post-Ottoman context, scholars tend to view coexistence as something that belongs to the Ottoman past, a time before conflict based on ethno-religious identities (especially Couroucli 2010). Problematically, this literature tends to view the loss of religious minorities as necessarily creating homogenized nations. Couroucli, for instance, claims that with the departure of the non-Muslim millets - the Jewish, Armenian, and Greek-Orthodox minorities-Turkey has long ago lost its pluralism. Such assumptions, however, rebound to reinforce the idea that minorities are those non-Muslim millets who are the subject of toleration, thus reducing coexistence to a form of hierarchical indulgence. Moreover, this understanding of coexistence, by equating plurality with those differences acknowledged by the millet system of the Ottoman Empire, makes it seem as though other forms of difference in Turkey today are not significant and do not require the sort of "labor of peace" that Bryant discusses in her introduction.

This chapter shifts the emphasis in this study of post-Ottoman plurality from coexistence/toleration to "conviviality" - that is, ways of both sharing and contesting particular lifestyles in a place through daily interactions and a sense of belonging (Duru 2015). I refer to "coexistence/ toleration" to emphasize the complex ways in which local discourses of tolerance are fed by and feed into historical and scholarly understandings of coexistence. And in my analysis of conviviality, "living together" is understood as sharing the same space and socio-economic resources, and a process that involves both cohesion and tension. While I emphasize conviviality and tensions due to differences in lifestyle and class (see also Navaro-Yashin 2006), I also complement conviviality with an analysis of coexistence/toleration, which I understand in the context of Turkey to apply specifically to recognized (former millets) and unrecognized minorities (e.g., Alevis and Kurds) who explicitly articulate their identity based on ethnic and religious difference in relation to the Sunni Muslim majority. My study of pluralism in the Turkish context draws attention 
to the intersection of class with ethnicity and religion (see also Smith 2000) through the concepts of coexistence/toleration and conviviality. In this chapter, I explore three complex effects of class in everyday interactions: (1) the ways in which belonging to the "same" class creates similar lifestyles and tastes and subsumes ethnic and religious differences; (2) how differences in lifestyle become exacerbated by class difference; and (3) how, nonetheless, class difference and economic mutual dependency may create a sense of belonging to Burgaz, through conviviality. Hard times, tensions as well as sensorial pleasures, produce a sense of place, where the islanders enjoy the shared ways of living in this diverse setting.

Throughout the chapter, I distinguish memories and practices of coexistence/toleration, which we might understand as "living with difference," from memories and practices of "conviviality," which I argue here are shared ways of living. While coexistence/toleration places emphasis on the need to share space with persons whom we already presume to be different, conviviality places emphasis on the production of place through shared attitudes and experiences. As I will show, conviviality may be seen as a particular form of everyday coexistence in which pluralism is self-consciously valued for its own sake. In this context, while memories of coexistence/toleration become a nostalgia for multiculturalism or an irreversible loss of pluralism as a result of nationalist homogenization (Bryant this volume, p. 17), memories of conviviality are used to create a sense of belonging to Burgaz. The shared ways of living that create such a sense of belonging to Burgaz include both sweet memories of leisure and also bitter memories of adaptation, hardship, class, and lifestyle differences.

This chapter responds to a particular strain in the analysis of the post-Ottoman space that takes as its subject the paradoxes of contemporary Ottoman nostalgia. In one form, that nostalgia posits that people got along well before the ravages of nation-state homogenization. Interestingly, this particular form of nostalgia coincides with official Turkish versions of the past that see life in the Ottoman Empire as harmonious and assert that it was broken up only by upstart minority nationalists. As a result, others have suggested in regard to Turkey that nostalgia for a pluralism that no longer exists is easy, but dealing with pluralism that actually exists (Kurdish, Alevi, etc.) is much more difficult (e.g., Onar 2009; Tambar 2014). Nicholas Doumanis (2013), in his important Before the Nation, attempts to take seriously the nostalgia of Greeks displaced from Anatolia before and during the 1923 population exchange. In that nostalgia, Greeks tend to assert a good life before they began to feel the effects of nation-state ideologies. However, while Doumanis sees the interactions of various religious groups in the empire as a form of everyday 
practice, he is never sufficiently able to solve the puzzle of its nostalgia today. I argue that this puzzle of nostalgia becomes easier to solve when one sees it as a nostalgia for a place to which one belonged that was created out of shared ways of living that encompassed and enjoyed diversity. This is different from seeing it as nostalgia for diversity itself, which suggests that we are nostalgic for specific features of other cultures.

Burgaz is an especially interesting site for exploring this question, as it is known in Turkey primarily as an elite resort of non-Muslim minorities that is dominated by the lifestyle of a secular upper class (compare Couroucli 2010: 223). Burgaz is one of nine islands in the Marmara Sea that constitute a separate district within the Istanbul Province and are today accessible by a short boat ride from central Istanbul. Based on my ethnographic research, I suggest that, contrary to the dominant perception of Burgaz as a home of non-Muslim elites, there is a significant class difference between the permanent and the summer inhabitants of the island who come from not only different ethno-religious groups but also different socio-economic backgrounds. The economy of Burgaz depends on the mutual relationship between the permanent inhabitants (mainly Zaza, Kurds, and Turks who are Alevi, Sunni, or Shafi'i from eastern and south-eastern Turkey) who run the shops and the restaurants, and the summer inhabitants, who are the customers, clients, and occasionally the employers (for instance hiring cleaners, gardeners, care takers, etc.). Moreover, despite these class differences there are strong community relationships and friendships that go beyond economic exchange and involve forms of recognition, respect, and gift giving.

\section{Conviviality and Cosmopolitanism}

Scholars frequently refer to the upper-class sociality of the Ottoman context as cosmopolitanism, a word with connotations of urban cultural pluralism (see, e.g., Zubaida 2002; Driessen 2005; Gekas 2009). In contradistinction to this, Ulrike Freitag argues that the political normative understanding of cultural pluralism implied in cosmopolitanism does not apply to the daily interactions among non-elite Ottoman subjects, which she describes as a form of conviviality. She shows that craftsmen and traders who belonged to different corporate organizations or guilds (Arabic tai'fa, Ottoman sinıf) engaged with each other in structured quotidian rituals in order to sort out tax collection (Freitag 2014). Locals and strangers socialized in coffee houses, taverns, and bathhouses, while families went on excursions together or visited each other's homes (Freitag 2014). ${ }^{1}$ Freitag's (2014) analysis is useful for thinking about how 
belonging to the same or similar classes intersects ethnic and religious differences. However, her analytical framework neither explains the negotiations between different classes and socio-economic groups nor the ways in which people from different classes negotiate ethno-religious differences.

I chose Burgaz as my fieldwork site because of its diverse population and because it was one of the rare places where people collectively resisted the 1955 riots, one of the most significant events of Republican Turkish history in that it resulted in a mass migration of remaining Greek Orthodox from Istanbul, primarily to Greece. I aimed to understand the diversity that still exists in Burgaz, and how persons who consider themselves "Burgazlı" understand that diversity. Hence I analyzed both the islanders' narratives of past diversity and their current practices of conviviality, notably interactions across different classes and ethno-religious communities. My fourteen months of research in Burgaz (June 2009-September 2010) included both formal and informal interviews regarding past diversity, including life history interviews, as well as long-term participant observation, including in cafes, restaurants, embroidery class, and social clubs, as well as churches, mosque, synagogue, and cemevi (Alevi places of worship). I also analyzed novels and a documentary film that Burgaz islanders have produced. This approach to current and past diversity and conviviality in the island also allowed me to assess how the island's population has changed over time and how long-term residents assess those transformations. As my research progressed, I began to understand the difference between memories and practices of conviviality and a sense of belonging to Burgaz, and my informants' narratives of coexistence/toleration, which fragments the sense of belonging into sharing space with different co-existing groups.

My first introduction to this distinction was when I met Orhan Özalp, a Burgazlı then in his mid-eighties, who was introduced to me by the security officer of one of the social clubs. The officer gave him my mobile number, and Orhan called me to arrange a time to meet. On the phone, I explained to him that I was doing doctoral research about the memories of Burgaz islanders currently living on the island. I added that as he was one of the oldest inhabitants in Burgaz, I would be very grateful for an interview with him. When he arrived for our morning meeting at the Blue Club, one of the island's social clubs, he brought along sheets on which he had listed names of friends, activities, and events. I was surprised that he was so well prepared, and I was happy that he was eager to talk to me. When I took out my small notebook, he exclaimed, "What, how can you write all the memories of many years in such a tiny book! Go get a proper notebook!" So, I went to the security desk and asked for 
a stack of A4 sheets and came back prepared to write, as he preferred me to take notes rather than to record the interview. I quote a section here from the uninterrupted stream in which he narrated his story of Burgaz to me:

Burgaz was an island of Greek fishermen. The permanent inhabitants of Burgaz, such as restaurant and coffee shop owners, storekeepers, fishermen, bakers, and grocers were all Greeks. My father was one of the first Turks, who came to Burgaz between 1915 and the 1920s. They were governmental officers, doctors, or lawyers, and the majority of them used the island as a sayfiye yeri [summer resort place] and were very few in number. In the 1930s and 1940s, summer inhabitants, such as Ashkenazi Jews and Germans, were rich and elite. The Jews of Burgaz were upper class in comparison to the Sephardic Jews who were lower middle class and who lived in Heybeli, another Princes' Island. The Jews of Heybeli and Istanbul used to come for a day trip to Burgaz as they could not afford to have houses in Burgaz. These Sephardic Jews became richer when the Democratic Party was in power between 1945 and 1960. Thus, from the late 1940s onwards, the Jews from Heybeli moved to Burgaz and the ones in Istanbul either rented or bought property in Burgaz.

This island was the island of fish. Greeks were very into fishing. Istavrit, uskumru, palamut, lüfer, torik, lapin, mercan, karagöz, orkinos, sinarit, kllıç balığ [names of fish varieties] ... there were so many fish that the fishnets used to break. When there was excess fish, the fishermen used to throw the excess back to the sea. The fishermen used to compete with each other in order to catch the biggest fish, especially orkinos. The fish caught were always displayed and sold in the market. The fishmonger used to mark the name of the fisherman on the orkinos caught, thus you would know who caught it and see the pride in the eyes of the fisherman when he walked in the market. Now, there are fewer and fewer fish in the sea. People are not as careful as the fishermen of the old days. The new generation put dynamite in the fishes' nests and fish when the fish were reproducing. Now the seagulls are hungry. I used to go fishing with my summer Greek friends. They had boats. We used to go to Sivriada and Yassiada [the uninhabited islands]. These islands were a heaven of fish and mussels. We used to go there in the afternoon, fish and eat the fish there, get drunk and sleep and come back in the morning. Sivriada geceleri [the nights of Sivriada] ...

These times were the times of bolluk [abundance, prosperity]. The rich Greeks had big gardens. For example, Taso's garden was full of 
fruit and vegetables. Quince, plum, lettuce, onion ... Mimi had a flower garden. In Foti's garden there were almond trees. They used to sell their fruit, vegetables and flowers to the islanders. Have you been to the Austrian chapel, high up in Burgaz? [I said "yes."] Good. The Austrian nuns used to sell the spare produce to the islanders. They had cows and chickens. The yogurt, cream, cheese, and milk that came from them were the best I have eaten in my life.

Do you know Kalpazankaya? [I said "yes, I have been there."] Do you know the Hişt Hişt story from Sait Faik?" [I said, "Yes I have read it."] Sait got inspired to write the story on the way to Kalpazankaya. He lived in Burgaz, he was much older than me but he was my friend and Burgaz is known as Sait Faik'in adası [Sait Faik's island]. In the story, Sait is on the Kalpazankaya road, he hears hişt hişt [similar to the "psst" sound that one person whispers to another to get their attention] but he cannot tell where it comes from. A plum tree? A hedgehog? A person? A bird? The sea? Saik writes it so well. It does not matter where the sound comes from. It is the sound of what makes you feel alive. $\mathrm{He}$ says in the end that if you do not hear hişt, then it matters. In Burgaz, you constantly hear a hişt sound, whether it is a person, a tree, the sea, the nature, an animal; these things keep you alive.

The times of the Greeks were the times of fun. I loved attending the church at Christmas and on important Greek Orthodox religious days. They offered pastry, biscuits, cookies, and meals at the church. There was not a mosque on the island until 1954. I did not care about the mosque. I did not care when it was built. I am not interested in religion, but I enjoyed attending the church because it was good fun to socialize with my Greek friends. There were five gazinos [dancing and drinking places] in Burgaz. In gazinos, Greek and foreign music played, sometimes live, sometimes from the gramophone. We danced day and night-tango, slow, swing ... The Greeks knew how to drink. There was always one person at the table who would control anyone who was getting too drunk. Now, people do not know how to drink. They get drunk and they start fights.

Adanın tipleri vard $\imath$ [there were unique, almost crazy people]. You know, every place has its own unique people. Ali Riza Kondos. Kondos means short in Greek. Ali Riza was a short drunkard. He had built a cave for himself in Burgaz. When we saw him, we used to yell pirr, which would make him so angry; he would throw stones at us and run after us. And then Şilep [Ocean liner] Hasan ... He was so huge we used to call him Şilep. The islanders used to give names to these unique people. Now, people are boring. The island was more diverse in the old days, we had adanın tipleri and everyone had a particular character, 
fault, weakness, funniness, craziness that made Burgaz a place of fun. Now, everyone is the same. People watch TV, they go to work. They do not have fun in their lives. There are no adanın tipleri anymore.

Orhan's memories of his youth are memories of conviviality, and they take their sources from the shared life in Burgaz. Orhan began the story of Burgaz with the Greeks, Turks, Ashkenazi Jews, Sephardic Jews, and Germans, which shows that ethnic and religious differences were acknowledged, not as "coexistence/toleration" but as part of what it meant to live in Burgaz. Orhan, like many of my Jewish, Muslim, German, and Armenian informants, joined and enjoyed the sociality at the churches. Greek rituals added to the richness of Burgaz. The luxurious summer lifestyle - full of discos, music and fun, drinking, and fishing lifestylesbrought people from different ethno-religious backgrounds together to socialize.

Furthermore, Orhan's perception of diversity is not limited to ethnic and religious differences. People's particularities, stories of craziness, anger, and jokes made Burgaz diverse and interesting to him. He also criticized greediness as what decreases the diversity in nature. The fact that he remembered what kind of fruits and vegetables grew in which garden, which dairy products came from where, and the names of particular fish shows that the tastes of these foods are significant elements that tie him to the island. He has embodied Burgaz through dancing, fishing, drinking, attending church, socializing with his friends, and having fun. Orhan's memories are of what Chau calls a "social sensorium," a term he uses to refer to "a sensorially rich social space such as found at a temple festival, a busy market, or a packed dance floor" (2008: 489, emphasis in original). However, while Chau explores "redhot sociality," or the way that sociality is produced through a type of heated frenzy, Orhan refers to the way that a sense of the social, of what it means to be a Burgazl, is produced through the experience of sensory diversity. Orhan's concept of bolluk, abundance, includes a diversity of people, animals, and natural beings. The "Hişt Hişt story of Saik Faik Abasıyanık (1993) that Orhan referred to indicates that Burgazwith its people, nature, animals, tastes, trees, and its sea-whispers into islanders' ears and keeps them alive. The experience of diversity is what makes Burgaz the place that it is, and enjoying diversity is what it means to be Burgazl.

However, while Orhan remembers the years prior to the 1950 s mainly as joyful and harmonious times for the non-Muslims and the Sunni Muslims, these were class-based memories. Orhan was a summer inhabitant; his friends were mainly wealthy summer inhabitants from di- 
verse ethno-religious backgrounds. In contrast, in the same years, male Alevi workers came to Burgaz from Turkey's east to do menial jobs. For the Alevis, the 1940s and 1950s were years of hardship, adaptation, and suffering. A couple of Alevi families came to Burgaz from Erzincan after the devastating earthquake in Erzincan in 1939. More male Alevi migrants came from Erzincan in the 1940s, to work during the summer season and take back what they earned to their families in Erzincan. My Greek, Sunni, and Alevi informants relate the immigration of the Alevis to economic factors. In the 1950s and 1960s, the migration from Anatolian villages to cities was increasing.

The Alevi men engaged in temporary migration to Burgaz in the 1940s did menial jobs such as helping the Greek fishermen reel in nets when they came back from fishing. They worked as hamal, carrying the furniture of the summer inhabitants when those inhabitants moved to the island and when they moved back to Istanbul. The Alevi men also built and restored houses, and worked as waiters and helpers in grocery shops, restaurants, and cafes. The building sector in Burgaz had been increasing and hence provided new job opportunities. They worked as doorkeepers and gardeners in Greek houses (especially in the Ay Nikola area, which is higher up, away from the town center), where they were given rooms or flats in which to stay. The zangoç (verger) of the Greek Orthodox Ay Yorgi church in Burgaz explained to me the story of how Ay Nikola became an Alevi neighborhood. He said: "Alevis came to work temporarily in summer. Most of them worked in Garipi monastery, in Ay Nikola, painting walls, and fixing things for the church. The priest who was in charge of the church at that time let the Alevis settle in the Ay Nikola area, near the Garipi church. Hence, they built small houses and made them bigger when they brought their family to the island." Thus, Ay Nikola started to become an Alevi neighborhood.

My male Alevi informants always began their tales of this period with the many difficulties they faced when they started working. Nuri and Mustafa say that their fathers were among the first Alevis to come to work in Burgaz and were looked down upon because they did menial jobs. For instance, Mustafa's father was a shoemaker and now does freelance casual jobs, like painting boats. Mustafa said: "The Greeks used to call us 'kıro.' When we passed near them they said 'To kıro einai' [He is kiro], and we started fighting with each other." Although the sentence was in Greek, the word kiro comes from Kurdish and is used in Turkish as a derogatory term for someone uneducated and ill-mannered. These two Alevi informants recall that when they were children, the rich Greek children used to exclude them because they were kiro. Nuri said, "When we wore shorts, $t$-shirts, and sunglasses, they [Greeks] used to belittle us 
and make fun of us. I was very upset about this because it was as if we did not have the right to wear these clothes and accessories. The Greeks behaved as if the sun and the summer belonged to them."

The tensions that arose between the Greeks and the Alevis were triggered by class differences ${ }^{2}$ as well as lifestyle differences. The summer inhabitants were generally upper-middle class, and they did not appreciate the presence of the Anatolian culture on the island. There were differences in city and village lifestyles. What people wear in Istanbul and Burgaz and in Erzincan and how people talk in these two different regions were markers of difference. The summer people in Burgaz wore bathing suits and modern European clothes such as shorts and t-shirts. When women went out in the afternoon, they wore perfume and elegant evening dresses. The Alevis grew up in villages in Erzincan. They wore modest and comfortable clothes to work in the fields and did not have elegant or fashionable dress. There were also differences in accents. Alevis from Erzincan spoke Zazaki and a version of Turkish that has a harder accent, in which letters like " $\mathrm{k}$ " and "g" are emphasized and syllables are rolled in their throat. In Istanbul, these letters are softer and the syllables are rolled in the mouth. In Burgaz, people sprinkle their speech with many Greek and Ladino words, as well.

Nuri also commented that in the times of his father's generation there was tension between Greek employees and Alevi workers. The Greeks who worked in the building sector, constructing walls and painting, employed Alevis as their assistants. The Alevis of his father's generation wanted to have more experience in the building sector. The Greeks gave menial jobs to Alevis, such as carrying the cement, while they (Greeks) performed the main duties of making the walls. When these Alevi male workers also wanted to learn to paint the walls, the Greeks did not let them. The Alevi men with whom I spoke interpreted this as "the Greeks did not want us to learn more and be better, because we might take their jobs." On the other hand, Nuri also said that the Greek women treated them well, giving food and clothes to them and being hospitable towards Alevi children. This also raises a significant gender issue, because while there was tension between the male Greek employers and the male Alevi employees, the Greek women apparently behaved in a maternal way towards Alevi children.

Nuri's and Mustafa's memories are ones of conviviality in the sense that I am using it here. My use of it derives less from the English and French meanings that connote feasting and celebration, and more from the Spanish convivencia, meaning "a shared life." Expanding on this meaning for their own work in Amazonia, Overing and Passes remark 
that conviviality's "features would include peacefulness, high morale and high affectivity, a metaphysics of human and non-human interconnectedness, a stress on kinship, good gifting-sharing, work relations and dialogue, a propensity for the informal and performative as against the formal and institutional, and an intense ethical and aesthetic valuing of sociable sociality" (2000: xiii-xiv, emphasis added). I would like to put emphasis here on the performative aspect of conviviality, as well as the valuing of "sociable sociality." Sociable sociality, or conviviality in the more conventional English sense, is something that, in this definition, is valued enough to be produced through performances that involve transforming "the violent, angry, ugly capricious forces of the universe into constructive, beautiful knowledge and capacities" (Ibid.: 6).

Conviviality, then, is not only "sociable sociality" but is the production and performance of that sociality, which often also involves control of tensions (see Bryant this volume, p. 21). Moreover, this control of tensions appears often to be gendered. For instance, in her ethnography of gendered spaces in a Karachi apartment building, Laura Ring shows that the production of the apartment building as a peaceful space is achieved not only through pleasurable moments but also through the management of tension in everyday interaction and exchange (Ring 2006). While Mustafa and Nuri were discriminated against because of differences in lifestyle, and Alevi employees and Greek employers experienced competition, Nuri also remembers the hospitality of Greek women. While he articulates that it was hard for them to adapt to island life and that there was tension between the previous settlers and themselves, he also emphasizes that he was a part of this conviviality, attending church, playing marbles, and fighting with Greek children. All of these memories made Burgaz his home.

I suggest, then, that conviviality is not only the ways of living that Orhan remembers so fondly but is a particular valuing of sociable sociality in the making of place. It is the sort of "everyday coexistence" discussed in the introduction but here given "an intense ethical and aesthetic valuing" and self-consciously performed. For those who live there, what makes Burgaz a place with which they identify is precisely this form of sociality; to be Burgazlı is to experience and value this sociality and to invest in its reproduction. That reproduction involves the performance of particular forms of sociality, as well as the management of tensions. Tension, then, is not absent from conviviality, just as it is not absent from what Bryant describes as the everyday "labor of peace." Rather, the management of tension is also a way of reproducing conviviality in that it performatively demonstrates the value placed on shared ways of life over other differences. 


\section{Conviviality and Coexistence}

Throughout the region of what was once the Ottoman Empire, the rise of nationalisms has led to homogenization processes: the construction of ethnic and national differences led to violence; forced migrations; oppression towards "minorities;" ${ }^{3}$ conflicts over territory, shared space, and borders; and changed demographics of the region (see also introduction and chapter 8 by Kasbarian). Political tensions between Turkey, Greece, and Cyprus, followed by the Turkish government's restrictive policies on minorities (e.g., Wealth Tax in 1942, ${ }^{4}$ the expulsion of persons with Greek citizenship in 1964) and the riots of 6-7 September 1955, which were an attack on the socio-economic power of the non-Muslims, were various ways of consolidating the ethnic and religious identity of the non-Muslims and making them feel as though they were "others within." This sensation was, I argue, a local consequence of coexistence/toleration, a creation of an Other and compartmentalization of people into groups that had to coexist or continue to survive within the majority. That sense of coexistence/toleration and its potential consequences triggered the emigration of non-Muslims, while the sense of conviviality tied the non-Muslim islanders to Burgaz and enabled them to remain in the island. Conviviality also enabled the newcomers such as Alevis and Kurds to adapt and become a part of Burgaz diversity.

The sense of coexistence/toleration appeared in Orhan's narrative in the form of the homogenization process that took away his friends. I asked Orhan: "You talk as if all these things do not exist anymore. What happened? What has changed? You said there were many, many Greeks? Where are they now?"

Orhan:

The Greeks left. They went to Greece, Australia, New Zealand, and the United States. Varlk Vergisi [the Wealth Tax], the 6-7 September events in 1955, the 27 May 1960 coup, the Cyprus events scared them all. They said: "Every twenty-five years, something will come up, the government will do something, we better leave." The government did many things wrong. My father had a Jewish friend who was required to pay such a high Varlik Vergisi that it was impossible to pay, thus he was sent to do military service in Aşkale. When my father's Jewish friend came back from Așkale, my father lent him some money that helped him reconstruct his business. Varlk Vergisi made the ekaliyet [an older term used for minorities] suffer economically. Furthermore, the Greeks had many shops in Beyoğlu, they all got destroyed during the 6-7 September events. Here in Burgaz nothing happened. We 
protected the island and no one could enter. However, what was happening in Istanbul and in Turkey was scary enough for them to leave. And they left. They sold their properties at a low price to Erzincanl Alevis who were working for them. Erzincanlis had saved money while working so Erzincanlı bought these properties. Now the permanent inhabitants are Alevis and Kurds.

When I asked Orhan what had changed, he referred to policies (the Wealth Tax in 1942), the riots on 6-7 September 1955, the coup in 1960, and events in Cyprus as what changed life in Burgaz. All of these were a logical consequence of what I refer to here as coexistence/toleration, or the management of difference. In this case, that difference was "managed" by the state as a form of homogenizing social engineering. For Orhan, it appeared as the distinction between the conviviality that he remembered and related with such fondness, his eyes sparkling as he looked dreamily towards the horizon, and the management of difference that led to his friends' departure and the political tensions, which he related staring at the ground and with much reticence. It was clear in his mind that government policies had brought a rupture to people's daily lives. Through those policies, the identity of the religious minorities was crystallized around their difference. Nevertheless, he still stressed the conviviality in Burgaz, in the ways in which his father helped a Jewish friend in Burgaz, and how the islanders did not turn against each other during the riots. On the contrary, the islanders cooperated with the police on Burgaz and protected the island from an outside attack, by waiting at the bays, scaring away the invaders who could not get to the island.

The Lausanne Treaty of 1923 provided the framework for this coexistence/toleration, as it made the Greek Orthodox, Armenians, and Jews remaining in the new Republic of Turkey official minorities. This official status of minority gave them recognition with particular rights, a recognition that Muslim groups, such as Kurds and Alevis, have been denied. But it also set them apart as non-Turkish, not a part of the majority, despite the fact that the Republic of Turkey was originally intended as a civic nationalism in which every Turkish citizen would be a Turk. Moreover, as Istanbul's Greek Orthodox were excluded from the population exchange with Greece, Istanbul remained the center of Greek Orthodox life until the 1950s. Istanbul, then, remained a heterogeneous city despite the nationalizing homogenization that affected the rest of the country, and as a result the Muslims and non-Muslims of Istanbul remember the 1955 riots as the event that caused rupture in a previous harmony.

While in Istanbul the riots are remembered as an experience of coexistence/toleration in which their religious identity made them the sub- 
ject of attack by non-Muslims, ${ }^{5}$ in Burgaz the resistance against the riots is remembered by my Greek, Muslim, German, and Alevi informants as a result of conviviality: Burgaz islanders collectively resisted the riots and protected their island from being invaded by outsiders. Kestane Karast (Aktel 2005) and Son Eylül [Last September] (Aktel 2008), both novelistic memoirs of Burgaz conviviality, describe how the islanders (both Muslims and non-Muslims) gathered together by ringing the bells of the church and made a plan of waiting and protecting the bays in order to prevent invasion of Burgaz during the 1955 riots. For instance, Ajda (a half Turkish - half Kurdish Sunni woman, who later married a Greek) told me that she was around fifteen years old in 1955 and clearly remembers her father saying, "Unless they kill me and step on my dead body, they will not be able to set foot in Burgaz." The shared memories of daily life and conviviality as described in Orhan's vignette had created such a strong Burgaz identity that it overcame ethnic and religious identities in times of crisis. The discursive effect of these memories (Bakhtin 1981: 269 ) is a type of "Burgaz ideology," a sense of belonging to Burgaz that is also infused with a moral discourse about how a "real" Burgazlı should behave, both in everyday life and in times of crisis.

In the early 1960s in Burgaz, people heard on the radio reports of the tensions in Cyprus and of Greek Cypriots oppressing Turkish Cypriots. Because the 1955 riots were linked to events in Cyprus, this later wave of intercommunal violence in this faraway island made the remaining Burgazlı Greeks anxious. And their fear would prove to be justified. The majority of my Burgaz informants, regardless of their ethnicity and religion, told me that 1964 was also one of the most important dates they remember, because that year was the time when their Greek friends with Greek citizenship were expelled. ${ }^{6}$ The islanders reminisce that many Greeks of Greek citizenship were married to Greeks of Turkish citizenship. Hence, not only the Greeks of Greek citizenship left, but their families left as well.

I wanted to explore how the remaining Burgaz islanders interpreted the departure of their Greek friends. Nuri narrated:

I used to play marbles with my friends [probably in the mid-1960s] and realized that my friends were gone. I did not understand why they left, as I was a child. I knew that some Greeks never did military service, and later, I understood that these Greeks were of Greek citizenship. Some of the ones who left were the ones who did not do military service.

The 1964 expulsion was a memory of coexistence/toleration for Nuri, because prior to that, he did not have in his mind a category for "Greeks 
with Greek citizenship" and "Greeks with Turkish citizenship." Nuri realized the ethno-religious and citizenship differences of his childhood friends at the moment when they left Burgaz. One Greek informant with Turkish citizenship (a male aged 65) recalled that when he came back from military service in 1971, the island was "empty." For him, the existence of Greeks made Burgaz a place with meaning and when many Greeks left, Burgaz became empty for him. The departure of the Greek friends who had to leave because of having Greek citizenship was an experienced consequence of coexistence/toleration.

Furthermore, the rise of Islamism and Kurdish nationalism in the 1980s and the Alevi revival in the 1990s helped to create a new appreciation of political and cultural pluralism (Neyzi 2001: 422; Çolak 2006: 587). During the years of my fieldwork (2009-10), the ruling Justice and Development Party (AKP) introduced "democratization packages" that included increased freedom of speech and Kurdish cultural rights intended to meet the Copenhagen criteria for Turkey's accession to the European Union (Baç 2005). In addition, the government initiated a dialogue with the Alevis to discuss their demands for political and cultural rights (Soner and Toktaș 2011). During this period, the Kemalist homogenizing impulses of early Republican Turkey were subject to new historical scrutiny, while varying ethnic and religious groups began to revive their identities, demand education in their native languages, and in the case of Alevis, the right and space to worship.

In Burgaz, this political context created an atmosphere where Alevis started to articulate their memories of coexistence/toleration by expressing the ways in which Alevis had been oppressed in and assimilated into the Ottoman Empire and the Turkish Republic. ${ }^{7}$ Alongside this politicization of identity, however, Alevis in Burgaz also recalled both bitter and sweet memories of conviviality in Burgaz. Quarrelling, fighting and playing marbles with the earlier established settlers in Burgaz and feeling sad about the departure of their Greek friends also signify their sense of belonging in Burgaz. When, at the end of the interview, I asked Nuri what Burgaz meant to him, he said "I was born in Burgaz, and I have sixty years of friendship with my oldest friend. You cannot find these long friendships in Istanbul or somewhere else for example." In this experience of locality, Burgaz is separate from other places. His years in Burgaz and his lifelong friends from there make the island a unique place for him. He added:

The islanders do not know how to walk on the streets of Istanbul. We do not know what traffic is, here on the island, we walk in the middle of the streets. Burgaz is a büyülü [mysterious] place; it has its own way 
of life. Burgaz means the sea, the seagulls and the pine trees for me. Whenever I go outside of Burgaz and I see seagulls and pine trees, it reminds me of Burgaz.

Nuri's comments echo those of Orhan and many other Burgaz islanders whom I met and talked with. This sense of Burgaz as having a special way of life is both what creates the sense of it as a place and also what its inhabitants value and attempt to reproduce.

\section{Negotiating Class and Religious Differences in Today's Burgaz}

Burgaz is heterogeneous not only in terms of ethnicity and religion, but also in terms of class difference. Minority religious communities in Turkey, as well as in Burgaz, tend to be well educated, and are financially comfortable. These minority elites (e.g., Armenian, German, Levantine, Greek, and Jewish) and majority elites (Sunni Muslims) usually go to the same foreign schools in Istanbul, work in similar sectors, and hence can afford to pay to eat out or to become members of social clubs. Sharing the same class creates similarities in lifestyle. In Bourdieu's (1990) terms, they have the economic and also the cultural capital and share a similar habitus. Their similar lifestyle creates milieux for interactions. They spend the weekends at the social clubs mostly swimming, sunbathing, playing scrabble or cards. They can afford to have most meals at cafes and restaurants and do not cook at home, with cleaning done by a maid. Most of the old, wooden mansions are owned by these summer residents. These mansions were designed and built by Armenian and Greek architects, mostly at the end of the nineteenth century (Tuğlacı 1992), and are spread between the center and the peak of the island.

However, the houses in Turgut Reis, toward the back of the island, are concrete constructions, most of them built by the permanent Zaza and Kurdish Alevis and Sunni Muslim inhabitants with their own hands. The waiters, seasonal workers, horse cart drivers, and menial laborers are mostly of Kurdish origin from Southeastern Turkey or of Turkic nationalities (e.g., Azerbaijan, Turkmenistan). Islanders' everyday interactions across classes, between summer and permanent inhabitants, between customers and restaurant and shop owners, form an important part of conviviality on the island. My last ethnographic account illustrates current practices of conviviality and the ways in which class and religious differences are negotiated in Burgaz today. It is a story of an Anatolian family who moved to Burgaz and became Burgazlı through acquired ap- 
preciation of the cultural diversity that is explicitly valued in the island and is what people there consider to be "sociable sociality."

I met Zümrüt on a winter day in January 2010 at the embroidery class taken by the permanent inhabitants, mainly Sunni Turkish and Kurdish Shafi'i women. While the other women were embroidering flowers and animal patterns on their fabric, Zümrüt wanted to embroider a big cross, a symbol of Christianity, and was looking for a cross pattern. I told her that I could bring a pattern and asked what she planned to do with it.

Zümrüt: I want to make a big cross for Niko Ağabey (elder brother). $\mathrm{He}$ is my boss and he is so nice. If I embroider a big cross on a big piece of fabric, he will be very happy and then we can put it in the church.

Author: I know Niko! He is in charge of Ay Yanni Church, isn't he? And how come he is your boss?

Zümrüt: I am the verger of the Metamorphosis church on the top of the island. Niko Ağabey [whom the reader will know from the previous section] is in charge of the bills and formalities of Ay Yanni and Metamorphosis churches.

I was struck by the fact that a Sunni Muslim family took care of the Greek Orthodox Church and that she called her boss ağabey, and so I went to visit Zümrüt Abla, coincidentally on Easter Day 2010. As I was thumbing through her poetry book, where she wrote about welcoming the spring on top of Burgaz, we heard some people entering the garden. A French tourist couple came to visit the church as guests of a Turkish and a Greek Burgazlı couple. I found myself in the middle of translating in Turkish and French the conversations between Zümrüt and the couple. The French woman asked how and why Zümrüt took this job. Zümrüt responded:

When I was young, with my friends, we used to clean the mosque in our village in Sivas, in Anatolia. I married my paternal uncle's son and came to Istanbul as a bride in 1987. While working in Istanbul, my husband developed good relationships with the Greeks. These Greeks who lived in Istanbul also had houses in Burgaz. When they proposed to us the job of taking care of the church, my husband and I accepted. I said: "both mosques and churches are the houses of God. Why wouldn't we take care of the church?"

When the French woman heard this, she had tears in her eyes and said, "While there are wars between different religions, it is very touching 
to see a Muslim woman taking care of a Christian church, this is very moving and impressive." When I translated that, Zümrüt did not react as if she was doing something spectacular or extraordinary but that was a natural act for her.

After regular visits to Zümrüt, I learned more about how she keeps the traces of her Anatolian rural life and how much she has learned from the Greek community. She climbs up and down Burgaz on her donkey, makes mantı (Turkish tortellini), and grows vegetables and herbs in her garden as she did in her village. Nonetheless, through interactions with Greeks and to do the job properly, Zümrüt and her son picked up a few Greek words, which are used in the mass, like $\psi \omega \mu i$ (bread), $\kappa \rho \alpha \sigma i$

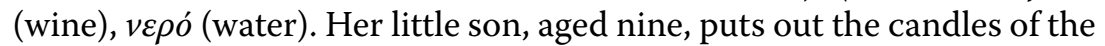
church, carries the ritualistic items listed above and holds the big keys of the church. Zümrüt knows the important Greek Orthodox religious days and the meaning of rituals, and she paints and cleans the church and shows it to visitors. While Niko was telling me the story of the departure of some Greeks, he added, "Today Greeks do not want to work as a verger. There are not many Greeks left to take care of the church, and those who stayed are all educated, with good jobs, and do not want to do this job." This sentence shows a significant class difference and also economic mutual dependency between the Greeks and the Muslims.

In Niko and Zümrüt's case, class difference and mutual dependency played a positive role in the ways in which they embraced their religious differences. Zümrüt and her husband accepted the job out of necessity. As they took care of the church, they were given free accommodation and salary. If Zümrüt and her husband had been religiously conservative or prejudiced, they could have simply refused to work under the authority of a Christian and taken jobs similar to those of other Muslims in the island. On the contrary, Zümrüt and her husband greatly respect Niko, their boss whom they address with a kinship term "elder brother." Zümrüt does not only do the basic duties of a verger, she looks after the church as if it were her own house, through cleaning the crystals of the church lantern one by one. She even embroidered a large cross on a piece of cloth that would be put on the alter table of the church, as a present to Niko Ağabey. To show their appreciation, the Greek community held Zümrüt's son's circumcision ceremony in the garden of Ay Yanni Church: a Muslim ritual took place in a Christian religious setting.

Even though the Muslim family took the job of a verger out of necessity, then, the relationship between Zümrüt and Niko goes beyond an employee/employer relationship. This is again an example of conviviality, where we see that Niko is not a "Greek" in Zümrüt's mind, but an "elder 
brother." Zümrüt, in return, is not "just a verger" or "Muslim" to Niko and the Greek community. They work together, they exchange gifts, and they make Burgaz a place where they can easily practice their religious rituals. The relationship between Zümrüt and Niko is not an exception. The boundaries of client/customer and employer/employee blur quite often and become that of friendship among café and restaurant owners or waiters and their regulars; grocery store owners and their clients; and Burgazlı people from different class, ethnic, and religious backgrounds.

\section{Conclusion}

This chapter argued that in the Turkish context, where the main word for living with difference is "toleration," "coexistence" represents a compartmentalization of the community into fragmented ethnic and religious groups who have to live together and share space. This sense of coexistence/toleration was contrasted with shared ways of living and a sense of belonging to a place through the prism of conviviality. I described the homogenization of nation-building and crystallization of ethnic and religious identities as a logical consequence of coexistence/toleration. Despite the negative connotations of hoşgörü (tolerance), however, a new discourse of human rights attached to minority groups has also resulted in a politics of difference that mobilized Alevis to ask for recognition. My approach to "conviviality," on the other hand, highlighted the cohesions and tensions that emerge from shared lifestyles and class difference, and how these tensions are managed in daily life and create a sense of place and belonging. I suggested that a more careful ethnographic analysis of specific locations in the post-Ottoman space may direct us beyond the coexistence/toleration paradigm to see the ways in which conviviality, or common ways of living, may lead to a conscious valuing of the sociable sociality of plural lives.

The research was supported by the University of Sussex under an Anthropology Departmental Fellowship; ORSAS (Overseas Research Student Awards Scheme); and Funds for Women Graduates under Foundation Grants.

Deniz Neriman Duru is a postdoctoral research fellow at the Media, Cognition, and Communication Department, University of Copenhagen. She wrote her Ph.D. dissertation in Social Anthropology at the University of Sussex on "Coexistence and Conviviality in Multi-Faith, Multi-Ethnic Burgazadası, Istanbul" and worked afterwards at the so- 
ciology department at the University of York. Her research interests include multiculturalism, diversity, conviviality, coexistence, anthropology of Turkey, Turkish migrants in Europe, and international migration within the Eurocrisis context.

\section{Notes}

1. In that sense, Freitag's take on conviviality is similar to Werbner's (2008) working class cosmopolitanism and Diouf's (2000) vernacular cosmopolitanism, in the ways in which they criticize Hannerz's (1990) elitist view of cosmopolitanism.

2. See Passerini (1987) and (1992), where she analyzes memories of the working class in Turin under a totalitarian regime.

3. During the disintegration of the Ottoman Empire and the "minoritization" process (Cowan 2001), the concepts of minority and majority came into the Balkan nations' state system. Cowan (2001:156) points out, "A minority is better understood as a product of particular ideological, social, political and economic processes, rather than a clear-cut component of a pre-existing multiplicity. In most cases, minorities are formulated at the moment of state formulation."

4. The CHP (Republican People's Party) government of İsmet İnönü passed the Varlık Vergisi (Wealth Tax) law in 1942 and explained that Varllk Vergisi aimed to redistribute the capital that was unequally and unfairly distributed during World War II (Ökte 1951: 15, cited in Güven 2006: 135; Kuyucu 2005: 370). Dönmes (non-Muslims, mostly Jews, who had converted to Islam) were supposed to pay double and non-Muslims had to pay ten times more (Güven 2006: 139, 141).

5. There has been a recent proliferation of writing and representation of the events. See especially the documentary films, Unutulmayan iki gün 6-7 Eylül [An unforgettable two days, 6-7 September] (2007) and 6-7 Eylül Belgeseli [The 6-7 September documentary], as well as Aktel (2008), Güven (2006), Kuyucu (2005), and Mills (2010).

6. The Greeks of Turkey with Greek citizenship were blamed for helping the Greek Cypriots economically (Akgönül 2007: 267) and also accused of being on the Greek side (Akgönül 2007: 252). In March 1964, the Inonu government decided to expel the Greeks with Greek citizenship (Akgönül 2007: 257, 409). The Turkish government did not renew the Seyrisefain pact, which was signed between Turkey and Greece in 1930, and which gave residence and free movement to Greek citizens in Turkey (Akgönül 2007: 86-87). With this pact, the Greeks who had migrated to Greece during the population exchange, and who had become Greek citizens were allowed to settle back and work in Turkey (Akgönül 2007: 87). Hence, work permits, freedom of movement and residence of Greeks with Greek citizenship were cancelled. Furthermore, this expulsion would make the Greeks of Greek citizenship lose their jobs thus enabling the Turks to take their places (Ak- 
gönül 2007: 261, 265). This would also "solve" the unemployment problems of the immigrants from the Anatolian villages to cities (Akgönül 2007: 265).

7. See Neyzi (2004) and Shankland (1999) for Alevi memories of the 1938 rebellion in Dersim and the massacres in Çorum, Kahramanmaraş, and Sivas/Madımak.

\section{References}

Abasıyanık, Sait Faik. 1993. "Hișt Hișt." Alemdağ’da var bir yllan [There is a snake in Alemdağ]. Istanbul: Bilgi Yayın Evi.

Abu-Nimer, Mohammed. 2001. Reconciliation, Justice and Coexistence. Maryland: Lexington Books.

Akgönül, Samim. 2007. Türkiye Rumları: Ulus Devlet Çağından Küreselleșme Çă̆ına Bir Azınlı̆̆ın Yok Oluş Süreci [The Greeks of Turkey: A process of annihilation from the age of the nation-state to the age of globalization]. Istanbul: Iletişim Yayınları.

Aktel, Engin. 2005. Kestane Karası. Istanbul: Everest Yayınları.

— 2008. Son Eylül: Elveda Antigoni [The last September: Goodbye Antigoni]. Istanbul: Everest Yayınları.

Anastasiou, Harry. 2002. "Communication Across Conflict Lines: The Case of Ethnically Divided Cyprus." Journal of Peace Research 39(5): 581-96.

Baç, Meltem Müftüler. 2005. “Turkey's Political Reforms and the Impact of the European Union." South European Society E Politics 10(1): 16-30.

Bakhtin, Mikhail Mikhajlovitj. 1981. The Dialogic Imagination. Texas: University of Texas Press.

Bourdieu, Pierre. 1990. The Logic of Practice, trans. Richard Nice. Cambridge: Polity.

Chau, Adam Yuet. 2008. "The Sensorial Production of the Social." Ethnos: Journal of Anthropology 73(4): 485-504.

Couroucli, Maria. 2010. "Empire Dust." In Eastern Christians in Anthropological Perspectives, ed. C. Hann and H. Goltz, 220-239. Oakland: University of California Press.

Cowan, Jane K. 2001. "Ambiguities of an Emancipatory Discourse: the Making of a Macedonian Minority in Greece." In Culture and Rights: Anthropological Perspectives, ed. J. K. Cowan, M. Dembour, and Richard A. Wilson, 152-176. Cambridge: Cambridge University.

Çolak, Yilmaz. 2006. "Ottomanism vs. Kemalism: Collective Memory and Cultural Pluralism in 1990s Turkey." Middle Eastern Studies 42(4): 587-602.

Dayton, Bruce, and Kriesberg, Louis. 2009. Conflict Transformation and Peacebuilding: Moving from Violence to Sustainable Peace. New York: Routledge.

Diouf, Mamadou. 2000. "The Senegalese Murid Trade Diaspora and the Making of a Vernacular Cosmopolitanism." Public Culture 12(3): 679-702.

Doumanis, Nicolas. 2013. Before the Nation: Muslim-Christian Coexistence and Its Destruction in Late Ottoman Anatolia. Oxford: Oxford University Press. 
Driessen, Henk. 2005. "Mediterranean Port Cities: Cosmopolitanism Reconsidered." History and Anthropology 16(1): 129-41.

Duru, Deniz N. 2015. "From Mosaic to Ebru: Conviviality in Multi-ethnic, Multi-faith Burgazadası, Istanbul." South European Society and Politics 20(2): 243-63.

Freitag, Ulrike. 2014. “'Cosmopolitanism' and 'Conviviality'? Some Conceptual Considerations Concerning the Late Ottoman Empire." European Journal of Cultural Studies 17(4): 375-91.

Gekas, Athanasios (Sakis). 2009. "Class and Cosmopolitanism: The Historiographical Fortunes of Merchants in Eastern Mediterranean Ports." Mediterranean Historical Review 24(2): 95-114.

Gidron, Benjamin, Stanley N. Katz, and Yeheskel Hasenfeld. 2002. Mobilising for Peace: Conflict Resolution in Northern Island, Israel/Palestine and South Africa. Oxford: Oxford University Press.

Güven, Dilek. 2006. Cumhuriyet Dönemi Azınlık Politikaları ve Stratejileri Bağlamında 6-7 Eylül Olayları [The events of 6-7 September in connection to the minority politics and strategies of the republican period]. Istanbul: Iletișim Yayınları.

Hannerz, Ulf. 1990. "Cosmopolitans and Locals in World Culture." Theory Culture Society 7: 237-51.

Kuyucu, Ali Tuna. 2005. "Ethno-Religious 'Unmixing' of 'Turkey': 6-7 September Riots as a Case in Turkish Nationalism." Nations and Nationalism 11(3): 361-80.

Mills, Amy. 2010. Streets of Memory: Landscape, Tolerance and National Identity in Istanbul. Athens: University of Georgia Press.

Navaro-Yashin, Yael. 2006. "De-Ethnicizing the Ethnography of Cyprus: Political and Social Conflict between the Turkish Cypriots and the Settlers from Turkey." In Divided Cyprus: Modernity, History, and an Island in Conflict, ed. Y. Papadakis, N. Peristianis, and G. Welz, 84-99. Bloomington: Indiana University Press.

Neyzi, Leyla. 2001. "Object or Subject? The Paradox of 'Youth' in Turkey" International Journal of Middle East Studies 33(2001): 411-32.

Neyzi, Leyla. 2004. "Exploring Memory through Oral History." In Balkan Identities: Nation and Memory, ed. M. Todorova, 60-76. London: Hurst \& Co.

Onar, Nora Fisher. 2009. "Echoes of a Universalism Lost: Rival Representations of the Ottomans in Today's Turkey" Middle Eastern Studies 45(2): 229-41.

Overing, Joanna, and Alan Passes, eds. 2000. The Anthropology of Love and Anger: The Aesthetics of Conviviality in Native Amazonia. London: Routledge.

Passerini, Luisa. 1987. Fascism in Popular Memory. Cambridge: Cambridge University Press.

Passerini, Luisa, ed. 1992. "Introduction." In Memory and Totalitarianism: International Yearbook of Oral History and Life Stories, Vol.1, 1-19. Oxford: Oxford University Press. 
Phillips, David. L. 1996. "Comprehensive Peace in the Balkans: The Kosovo Question." Human Rights Quarterly 18(4): 821-32.

Ring, Laura. 2006. Zenana: Everyday Peace in a Karachi Apartment Building. Bloomington: Indiana University Press.

Shankland, David. 1999. Islam and Society in Turkey. Cambridgeshire: Eothen Press.

Smith, Neil. 2000. "What Happened to Class?” Environment and Planning A, 32: 1011-32.

Soner, Bayram A., and Şule Toktaş. 2011. "Alevis and Alevism in the Changing Context of Turkish Politics: The Justice and Development Party's Alevi Opening." Turkish Studies 12(3): 419-34.

Tambar, Kabir. 2014. The Reckoning of Pluralism: Political Belonging and the Demand of History in Turkey. Stanford, CA: Stanford University Press.

Tuğlacı, Pars. 1992. Tarih Boyunca Istanbul Adaları [The islands of Istanbul throughout history], Vol 2. İstanbul: Pars Yayınları.

Unutulmayan iki gün 6-7 Eylül [An unforgettable two days: 6-7 September]. 2007. Dir. Ridvan Akar. <http://video.google.com/videoplay?docid=82901 05516265035220> (Accessed 18 April 2012).

Wallensteen, Peter. 2007. Understanding Conflict Resolution: War, Peace and the Global System. London: Sage Publications.

Werbner, Pnina, ed. 2008. Anthropology and the New Cosmopolitanism: Rooted Feminist and Vernacular Perspectives. Oxford: Berg Publishing.

Zubaida, Sami. 2002. "Middle Eastern Experiences of Cosmopolitanism." In Conceiving Cosmopolitanism, ed. S. Vertovec and R. Cohen, 32-41. Oxford: Oxford University Press. 
2. Chapter $7 \cdot 6$

\section{"If You Write This Tačno, It Will Be Točno!"}

Language Ideologies and Linguistic Practices

in Postwar Bosnia and Herzegovina

\section{AZRA HROMADŽIĆ}

This chapter is not available in the open access edition due to rights restrictions. It is accessible in the print and retail e-book editions, spanning pages $180-204$. 


\section{Part III \\ $\{\cdot\}$}

Negotiating Everyday Coexistence in the Shadow of Conflict 

2. Chapter $8 \cdot 6$

\title{
The Istanbul Armenians
}

Negotiating Coexistence

\author{
SOSSIE KASBARIAN
}

\section{Dismantling Nationalist Narratives, Critiquing the Nation}

$\mathrm{W}_{\text {it }}$

ith the prospect of membership into the European Union (EU) in sight, Turkey has been undergoing a tortuous democratization since the early 2000s. A question at the heart of this process is whether it can deal with its internal diversity, reconcile historical tensions, and heal deep wounds. ${ }^{1}$ This involves the rethinking of fundamental concepts like nationhood and belonging, citizenship and rights, and relations between state, authority and religion. This chapter looks at everyday personal and social negotiations in being Armenian in Istanbul and the struggle to claim a coexistent Armenian space within the Turkish nation. ${ }^{2}$

One founding myth of the Turkish Republic established in 1923 is the ethnic purity of the nation, rendering the very existence of Others and Other narratives problematic from the outset. Unlike the Ottoman identity, the new republic privileged ethnicity over religion, a particularly difficult condition for the non-Muslim, non-Turkish communities. From the turn of the century onward Ottoman leaders and Young Turks pursued an agenda that relentlessly aimed to decrease the number of non-Muslims living within the new borders of the emerging nation. Mustafa Kemal and his followers introduced policies and programs designed to aggressively homogenize Turkish society and to create a new national identity that excluded Others. A nationalist historiography rooted in the famous three-day speech given by Kemal in 1927 at the Second Congress of the Republican People's Party "articulated and narrated the excluded minorities as the vanquished, and then proceeded to attribute to them the exactly opposite characteristics: the excluded were stripped of most of their agency, and the very little they were permitted to exercise was 
of course depicted within parameters defined by the triumphant group, thereby appearing totally subversive and immoral" (Göçek 2006, 2013: 89). The emerging nation and new state were "constructed through a narrative that denied, forgot and silenced minorities" (Mills 2008: 386). Göçek's analysis links the "hegemony of Turkish nationalism" and "the hegemony of 1915 " in constructing a prevailing master-narrative whereby Armenians (and other non-Muslim minorities) were depicted as untrustworthy and inferior, and ultimately ungrateful and treacherous to Ottoman/Turkish benevolence and tolerance.

Although there was considerable continuity between Ottoman and Turkish institutions, there was a concerted policy of "engineering oblivion" that cut off the Republic from its past and in particular from its non-Muslim and non-Turkish peoples and their histories (Kadıoglu 2007: 289). Kadıoğlu singles out education as the "vehicle for the reproduction of oblivion in Turkey" making contemporary Turks "ignorant about the multi-religious and multi-ethnic history of the lands that they inhabit ... paving the way to an official rhetoric of denial" (Ibid). Hence, the very concept of the coexistence of Others and their respective experiences, their non-Turkish, non-Muslim identities, were wiped out in the foundation of the Turkish state and their continuing existence problematic.

In 1913 one in every five people in (what became) Turkish lands was a non-Muslim. At the end of 1923 that number was one in forty (Keyder 1989: 67). Despite the constitution of 1924 stating that being a Turk is self-ascriptive, in practice non-Muslim minority groups have always been considered Others. The Turkification policies in operation reinforced the dominance of Sunni Islam and Turkishness in every aspect of life. Today the non-Muslim minority groups constitute less than 1 percent of the population of Turkey. Of these, the Armenian Orthodox are estimated to comprise around $65,000^{3}$ (US State Department 2010). ${ }^{4}$ The Turkish state distinguishes between two types of minorities. The first are the three officially recognized non-Muslim minorities (the Armenian Orthodox, the Greek Orthodox, and the Jews) as protected by the Treaty of Lausanne (1923). The second category covers religious communities that are not linked to a particular ethnic group (e.g., the Jehovah's Witnesses and the Baha'is.) All Muslim minorities (Kurds, Alevis, Circassians, etc.) were deemed to belong to the Turkish nation at the time of the foundation of the Republic. Despite the fact that minorities were legal citizens, in practice citizenship became an instrument of forced assimilation to a Turkish national identity rather than a guaranteed set of rights. In discussing the concept of minority in the Turkish context, Akgönül (2013: 77) says, "[N]on-Muslims were meant to be exterminated, not assimilated, during the efforts to build a homogeneous nation. As 
in all nation-building processes, the utopia of a homogenous nation in Turkey based itself on three principal mechanisms: extermination, assimilation and folklorization." The remnant non-Muslims, were either made invisible, forced to flee, or "ornamentalized."

Kemalist secularist principles that founded the state, meant that religion, in particular non-Muslim religions, have not been practiced freely. Religious identity and the practice of religion remains an area fraught with constant negotiation in modern Turkey, caught between the forces of conservative Islamism (as represented by the ruling AKP) and a strict Kemalist secularism (represented by the Republican People's Party, CHP). The Treaty of Lausanne stipulated equal treatment under the law, and rights and privileges to be given to religious minorities, including the right to maintain their own schools, churches, foundations and other institutions, which enabled them to maintain their ethnic, religious, and cultural identity, at least in theory. ${ }^{5}$ In practice all of these institutions face fundamental problems due to this relationship with the state. Since the foundation of the Republic in 1923, there have been strict restrictions on religious minorities owning, maintaining, or transferring their property (individual and communal), as well as restrictions in the training of teachers and clergy of the minority. In fact successive Turkish governments have systematically confiscated properties from religious minorities since the foundation of the republic, most notably in 1936 with the Foundations Law, in 1971 with the Private University Law, and in 1974 when a law recognized only the ownership of religious community properties registered in 1936.

According to the national census of 1927, Turkish was not the native language of around 28 percent of the city's population. Out of 794,000 people in the city, 92,000 spoke Greek, 45,000 spoke Armenian, 39,000 spoke Ladino, 6,000 spoke French, and 6,000 spoke Albanian. The remaining 31,300 spoke a mix of other languages, including Arabic, Kurdish, Persian, Circassian, and Bulgarian (Aslan 2007). After the Republican period, there continued an assault by assimilationist and exclusionary policies and practices, designed to eradicate these differences. The "Citizen Speak Turkish" campaign initiated in 1928 (but with lasting impact) made the speaking of minority languages in public an offence, ${ }^{6}$ enforcing Turkification in the public sphere. Many of my interviewees spoke of childhoods fearful of inadvertently speaking to their parents in Armenian when out in public, creating another layer of personal trauma and insecurity in the shared urban space. The Law of Settlement in 1934, which aimed to assimilate Balkan Muslims and Kurds by settling them in areas populated with Turkish speakers, also banned those whose mother tongue was not Turkish from establishing towns and villages. The state 
changed the names of cities, towns, and villages into Turkish. The Law of Surnames of 1934 forced all citizens to take Turkish surnames (Aslan 2007). There continued state policies designed to make life for the minorities uncomfortable and in some cases to threaten their existence, including the Wealth Tax in 1942 (which disproportionally affected non-Muslim minorities), and the Istanbul pogrom of 6-7 September 1955, when gangs organized by state institutions attacked minority businesses, homes and churches. During the Cyprus crisis in 1963-64, minorities were forced to flee Turkey, and limited to taking only $\$ 100$ with them. These policies together reveal a state intent on eradicating or subjugating its non-Muslim minorities. Göçek (2006, 2013: 102) stresses the historical continuities of the Ottoman Empire and the Turkish republic in "state-sponsored prejudice and violence against minorities in the name of nationalism."

Furthermore, the conceptualization of non-Muslim minorities in modern Turkey is directly linked to how the Ottoman Empire and its legacies are approached in popular and political discourse. There are two broad, seemingly contradictory, myths at play when one looks at the discourse surrounding the change from an Ottoman to a Turkish state. The first is the reigning nationalist discourse that presents Turkey as a homogenous state of ethnic Turks and Muslims. In this exclusionary discourse, all Others are deemed foreigners, and should they not prove docile and compliant, they are seen as threats to the integrity and coherence of the Turkish state.

The second is a nostalgia for a cosmopolitan empire, with Istanbul the city of cities at its center, viewed with a romantic and sentimental wistfulness for a mythical period when people of different ethnicities, religions, languages, classes, and backgrounds lived side by side, in what the late Tony Judt (2010: 206) has called "lost cosmopolitan cities." In recent years this celebratory nostalgia for an apparently peaceful and idealistic past has been expounded by both Turkish and non-Turkish writers and scholars, with little critical reflection, nor adequate engagement with historical data. In Turkey, this extended to musings about the multicultural past inhabitants of Istanbul, of which there are tiny communities left over. In some cases this "boutique multiculturalism" ${ }^{8}$ led to "white Turks" (middle class, secular, Kemalist, Sunni, urban, liberal) attending Christmas services in churches in Istanbul, as part of a self-consciously constructed Europeanness. This nostalgia tends to gloss over the structural and everyday discrimination minorities experienced under the Ottoman regime, and it infantilizes and fossilizes the remaining communities as a historical relic. As Bryant argues in the introduction to this volume (p. 6) "current popular nostalgia for a multicultural past may 
mask denial of the ways in which that multiculturalism was destroyed," and it certainly ignores the intrinsic violence of imperialism and the power asymmetries contained within. Mills, Reilly, and Philliou (2011: 135) talk about the paradoxical way that the Ottoman past is viewed in scholarship, through "the lens of nostalgia," but also as a "time of backwardness and decline leaving a dolorous legacy that must be undone and overcome." This paradox can be extended to the Christian minorities, the "physical and social remnants of the past" in modern Turkey as being "both ubiquitous and unacknowledged, both remembered nostalgically and rejected ideologically" (Ibid.).

Cosmopolitan nostalgia has been very limited in terms of political potential to open up Turkish notions of citizenship, identity, and belonging. This trend among Turks who are unsympathetic to the ruling AKP is partly a response to their perceptions that the party has an Islamist agenda that seeks to dismantle the laicist foundations of the Kemalist state. "White Turks," according to Akgönül (2013: 90) find themselves confronting "a new type of otherness, the 'Islamist' movement-with the headscarf as an icon-on one side and the Kurdish presence associated with violence, on the other," resulting in nostalgia for the "former others" along with "a firm belief that Istanbul was more cosmopolitan, 'civilized' and 'habitable' before the non-Muslims were deported or forced to flee."

Central to the Ottoman nostalgia is "tolerance as a political discourse" and the vision of a pluralist empire with Istanbul as its cosmopolitan center. This tolerance is often presented as a critique of an intolerant present (reflected in the intolerance each Turkish faction has for the others). Implicit in the tolerance discourse is the existence of the dominant majority that is doing the "tolerating" and therefore an intrinsic disapproval at the core for the "tolerated" (Mills 2011). As Bryant discusses in the introduction to this volume (p. 12) "toleration implies living with or tolerating beliefs of practices that one finds wrong or disagreeable for social, economic, or political reasons" and "tolerance assumes that difference is perceived negatively." She contrasts the ideological position of "tolerance" to quotidian realities and negotiations encapsulated in "coexistence," the day to day living together that "attempts to interrogate understandings of difference and boundaries including indifference to difference," where there are "rituals of accommodation that simultaneously define(d) and cross(ed) boundaries."

All nation-states are built on forgetting and remembering selectively. In the Turkish case the persistent denial of the harsh realities of the Ottoman past in relation to the minorities still within constitutes the very foundation of the nationalist state and is constantly reproduced in the 
hegemonic narrative. Central to this hegemony is the complete silencing of the voice of these minorities, where counter-narratives are regarded as threats to the nation. Historically the coexistence of different narratives has not been tolerated, and regardless of the apparent democratization and liberalization policies since 2000 they are interpreted as developments that need to be suppressed, and opposed. Despite this, recent oral history projects have unearthed a hesitant emerging space for counter-memories and counter-narratives (Mills 2008; Üngör 2014). Mills (2010: 211) remarks, "The price of belonging in Turkey comes at a cost-the forgetting of particular histories at the expense of the frequent retelling of others and the silencing of particular memories that cannot entirely be repressed." In the Armenian case, the specter of the genocide of 1915 and being considered fifth columns in the state of the perpetrators led to a particularly alienated position. As one recent analysis has poetically put it, it has led to "one hundred years of abandonment," alongside "a clear disengagement from a quest of justice for themselves, but also a clear-albeit forced-disengagement from their relatives in the diaspora.... The never-spoken cost for Istanbul Armenians was the complete negation of their political identity and history" (Erbal and Suciyan 2011). Suciyan (2012), drawing on Hannah Arendt's study of being a Jew in Europe in the nineteenth century, talks of the pressure on Armenians in Turkey "to assimilate into anti-Armenian campaigns, which also entails hatred against and dehumanization of the Armenian diaspora.... In this way, you are expected to become an enemy of your own past, of your own biography, and reject your own present." One recent example of this, in April 2014, was the apparent wish of Turkey's Armenians to nominate PM Erdoğan for the Nobel Peace Prize. ${ }^{9}$ This demonstrates the utter subjugation of this community, who (outwardly at least) were grateful and impressed by Erdoğan's acknowledgment of the deaths of Armenians during the end days of the Ottoman Empire ${ }^{10}$ in a statement ${ }^{11}$ that Öktem has called a "perfect example of denialist-lite,"12 much to the dismay and shock of the Armenian diaspora. Suciyan posits that a rejection or surrendering of the Armenian past and indeed the present in Turkey is the "only way offered to survive in a state of denial." The charge is that "coexistence" in the Turkish state for Armenians has necessitated the usurping of one's identity and an alienation of the self, leading to a chastened and insecure existence. The Istanbul Armenians are in the unique position of being the physical embodiment of a highly politicized wound in the nationalist narrative-physical reminders of the genocidal past but also the remnants of centuries of Ottoman Armenian lives and contributions to the nation, both of which the Turkish state denies, erases, or belittles. 


\section{Signs of Change: Post-2005}

While there have been ground-breaking works in scholarship on the tragic fate of the Ottoman Armenians in recent years, ${ }^{13}$ it is the emergence of pioneering Turkish academics engaging with these issues in a critical manner that has had the most impact in Turkey itself. ${ }^{14}$ In late 2008 a controversial "apology campaign" initiated by four Turkish intellectuals was circulated, gathering over 30,000 signatures of Turks and Kurds "apologizing" for the events of $1915 .{ }^{15}$ The works of novelists like Nobel laureate Orhan Pamuk and Elif Shafak have also had widespread international impact, although both, along with other public intellectuals and journalists, have been chastened by the threats from the state, under Article 301 of the Turkish penal code that makes it a crime to "insult the Turkish nation."

If one were to pinpoint a date for the "opening" of a public debate on Armenians in the Ottoman Empire, it would be 2005, when the ninetieth anniversary of the genocide sparked a new effort by a few Turkish intellectuals to confront the official denialist line by focusing on the human story. The ground-breaking conference, "Ottoman Armenians during the Demise of the Empire: Responsible Scholarship and Issues of Democracy," in September of that year marked a turning point in public discourse in terms of what was possible to discuss and the terms of that debate. The conference was referred to as the Genocide Conference in the mainstream media, and there was pressure to cancel it from politicians and officials, leading the venue to be changed several times and some ugly scenes at Bilgi University, where it was eventually held. Those present, upon returning to their home institutions, continued working in this field, creating, claiming, and shaping a new space and discourse that transgressed the hegemonic operative of genocide recognition and denial (Kasbarian and Öktem 2014).

Arguably the most influential vehicle for a change in social attitudes in Turkey was My Grandmother (Çetin 2004, 2008), a biographical story written by the human rights lawyer Fethiye Çetin about her grandmother, who revealed near her death that she had in fact been born Armenian and had survived the genocide by being taken in by a Turkish family. The incredible impact of this modest book lies in its poignant human story. Columnist Tuba Akyol in her review of the book stated, "stories can do what large numbers or concepts cannot do.... Concepts are cold, stories can touch you inside" (Akyol 2005). Ayșe Gül Altınay has written of the success of My Grandmother in employing "Arendtian storytelling to open up a creative space for historical critique and reconciliation" (2006: 127), by evoking curiosity about one's ancestry, de- 
constructing the nationalist homogenous nation, thereby allowing for a construction of a hybrid Self. She describes the momentum the book has created as a completely unexpected "phenomenon," with Çetin touring throughout Turkey and internationally, being treated as a "celebrity" by both Turks and Armenians ${ }^{16}$ (and others) who are touched by this powerful personal story in surprising ways. Çetin herself talks about the shocking discovery of her Armenian roots as suddenly seeing "the world through different eyes" (quoted in Bilefsky 2012).

This development in particular, tapping into the critical studies and gender studies space, introduces a radical new space for empathy, the exploration of personal and historical memories and sharing of personal stories. It is both subtle and powerful, as it is not taken seriously in the realm of high politics and yet has a real impact on people's attitudes. This approach is a serious challenge as it is an entirely different kind of discourse to which nationalists cannot respond-thereby acting as a transgressive undermining of the state discourse.

These tentative surfacings of hidden or silenced histories and identities have led to a wave of Turkish citizens discovering and uncovering their Armenian (and other non-Turkish) roots and working through their family histories. Some Armenian orphans of the genocide and later massacres were taken in by local Muslim families, who changed their names and converted the children to Islam. The Dersim Armenians are one such case of a group reclaiming their Armenian identity and some now choosing to get baptized. They have even formed a union to teach Armenian and restore graves and churches in the Tunceli province. ${ }^{17}$ There has emerged a distinct phenomenon of the "Islamized (or Muslim) Armenians," a subject explored in a trail-blazing conference at Boğaziçi University in November 2013. ${ }^{18}$ Islamized Armenians as a concept are a huge challenge for the Turkish (almost exclusively Muslim) state, which has to confront the previously silenced, growing numbers of citizens rediscovering and claiming Armenian roots. There has simultaneously also been a new awareness of the mongrel roots of most Turkish citizens, something that contradicts and challenges Kemalist principles and the state's official nationalist discourse. This process of discovery for some has led to a personal crisis; for others it has been a chance to question the exclusionary racist tenets of Turkish nationalism from a personal position. Nükhet Kardam, writing in Today's Zaman, expressed this lyrically:

Once I dug into my family history, I found forgotten, hidden and suppressed identities. My grandmother's father is a "Rum," the descendent of a Byzantine "Tekfur" who fought alongside the Ottomans and later converted to Islam. My grandmother's mother is the grandchild of the 
revered Kurdish leader Mir Bedirhan who ruled a large semi-autonomous Kurdish territory in the Ottoman Empire. My great uncle's wife is Greek but had to change her name and religion in order to marry the love of her life. My family adopted a girl and included her in our family registry. She was born in 1910, in Erzincan in Eastern Turkey. She could very well be Armenian, as many Armenian children were saved and adopted by Turkish families during that time. I now look at Greeks, Armenians, and Kurds with a very different eye, now that I know I belong to each one in some way. I then began to ask myself many questions about who really is a Turk. (Kardam 2011)

This intertwining of the historical, the political, and the intimate offers a radical new space for exploration, expression, and political action. Whereas high politics has a distancing quality and can be ignored by (the increasing number of) disenfranchised and disinterested populations, politics as embodied in the personal speaks to our common humanity and revives interest from a human position.

These developments have led to the inevitable nationalist backlash. The most significant event was the gunning down of the prominent Istanbul Armenian and newspaper editor, Hrant Dink, outside the offices of $\operatorname{Agos}^{19}$ in central Istanbul on 19 January 2007. His murder and his funeral march when hundreds of thousands took to the streets bearing the signs "We are all Armenians; we are all Hrant Dink" marked a turning point for Istanbul Armenians, and arguably for Turkish society as a whole. This great show of solidarity with the Armenians of Turkey was highly symbolic and perhaps the most public display of the possibility of an emerging shared post-nationalist common identity in Turkey (despite immediate nationalist backlashes). This unprecedented development also exposed the polarized attitudes around "the Armenian issue," and forced the idea of "Turkishness" forward for public debate and reflection (Türkmen-Dervişoğlu 2013: 675).

The loss of the most noted Armenian public intellectual in Turkey was an unmitigated calamity for the community. One Turkish activist said to me, "the Armenian community has lost its voice," and yet his death has given an impetus to many others. Dink's murder brought the plight of the Istanbul Armenians to the forefront, and opened up the parameters of what it was possible to discuss. The same activist explained, "What has changed is that people can now talk freely about the genocide, it seeped into people's discourse and conversation more. People also started talking about their own families and the past." ${ }^{20}$

Within the Armenian community Hrant Dink's murder resulted in two apparently contradictory trends: on the one hand there is greater 
fear and retreat by some elements of the Armenian community; and on the other, especially among the younger generation, an increased boldness in remembering and claiming their identity and making demands. With regard to the former tendency, I heard several stories of Armenian families buying property in Armenia or getting visas for the West in case they had to make a quick escape. For the latter group, the assassination was a wake-up call to fight for the rights and freedoms that Dink had dedicated his life to, to retrieve their lost and silenced voices and identities. ${ }^{21}$ The murder has also made the local and transnational network of Turkish, Armenian, and other activists working in this new, emerging shared space, closer, more coherent, and more confident (Kasbarian and Öktem 2014).

The perpetrators of Dink's murder have not been brought to justice, and the protracted legal process has been farcical. Murders of religious minorities have continued steadily with few repercussions, giving the impression that the infamous deep state tolerates this. ${ }^{22}$ Turkey is considered a "country of particular concern" by the U.S. Commission on International Religious Freedom..$^{23}$ Most recently, an Armenian soldier was shot dead under suspicious circumstances while performing his national service, on 24 April (the day the genocide is commemorated) 2011. His murder was whitewashed by a military court in Diyarbakır in March 2013. ${ }^{24}$

And yet there does seem to be a creeping sense of realization that despite the nationalist backlashes, and denialist strongholds in state institutions, developments in the liberal public sphere have radical longterm potential. Nonetheless, there is no real change at the official level, nor is there a mellowing in the militancy of nationalists, and arguably among wider Turkish society, where negative portrayals of, and attitudes toward, Armenians are the norm..$^{25}$

\section{Istanbul as Hub and Synergy}

Istanbul acts as a hub for the launch of new Armenian-Turkish initiatives and the creation of a new space and discourse. While not the focus of this chapter, it is important to recognize that Istanbul also acts as a site for reconciliation initiatives, often financed or led by non-Turkish or Armenian groups, mediators, and international organizations. ${ }^{26}$ In this process the Istanbul Armenians have a potentially unique pivotal role to play, and yet they rarely seem to be at the forefront of such projects, lacking the agency to take on a leadership or public role. 
Osman Kavala, Chairman of the Board of Anadolu Kültür, ${ }^{27}$ a prominent NGO working in art and culture, talked about a three-pronged approach-local community, diaspora, and the Republic of Armenia. He stressed the importance of the city as the site where all these factions can meet: "Istanbul is really a cosmopolitan place and the infrastructure allows us to work well with others here-NGOs, academics, artists.... Istanbul is a natural place for such meetings, making for a kind of synergy." ${ }^{28}$ Kavala prefers to limit his remit to the civil society sector, though getting involved with the state is sometimes unavoidable, as in the case of Anadolu Kültür's project in Ani to restore churches. Being located in Istanbul has meant that these initiatives are able to attract external funding from a wide range of sources invested in these fields. Kavala is realistic about the impact of exhibitions and programs in Istanbul, saying that the audience is usually limited to a progressive elite who are already receptive to these ideas, but at least these projects document and publicize the historic and contemporary presence of minorities.

There is also a recent trend to explore or rediscover the multi-ethnic past (inhabitants) of Turkey through artistic projects. Many of these projects also travel to other countries, facilitated and supported by diaspora groups and institutions, an intrinsic part of the burgeoning transnational network of Turks, Armenians, Kurds, Greeks, Cypriots, and others committed to constructing an emerging shared space. One prominent exhibition was My Dear Brother: Armenians in Turkey 100 Years Ago, a collection of eight hundred postcards depicting Armenian life in Anatolia at the turn of the century. The exhibition opened at the Karş1 Gallery in Istanbul in January 2005 and travelled to several cities, including London, where it attracted great attention at the Brunei Gallery of the School of Oriental and African Studies for nearly three months. ${ }^{29}$ The exhibition of both enlarged images and original postcards was conceived and put together by Osman Köker. A few initiatives showcasing the minorities came through the Istanbul 2010 European City of Culture program, including the book Classical Ottoman Music and Armenians by Istanbul-born French Armenian Aram Kerovpyan (2010). Most important in articulating the position of Armenians in Turkey (amid a wider remit of democracy-building and human rights issues in Turkey and beyond) is the Hrant Dink Foundation, ${ }^{30}$ established after the assassination of the most prominent Istanbul Armenian.

While Istanbul is the natural hub for meetings, negotiations, and plans, many of the actual projects also concern the historic Armenian lands in the east. The retrieving and piecing together of past Armenian life might emanate from Istanbul where the residual community survives, but it 
also connects to their historical spaces in Anatolia in particular. One notable recent development concerned the tenth-century Cathedral Church of the Holy Cross, on Aktamar Island on Lake Van. Between May 2005 and October 2006, the church underwent a controversial restoration program financed by the Turkish Ministry of Culture. It officially re-opened as a museum on 29 March 2007 in a ceremony attended by the Turkish Minister of Culture, government officials, ambassadors of several countries, the Armenian Patriarch of Istanbul Mesrob II, a delegation from Armenia, and international journalists. The Governor of Van described the refurbishing of the church as "a show of Turkey's respect for history and culture," and yet the fact that it was turned into a museum rather than re-opened as a place of worship, that permission to remount the cross on top of the church was not given, that the official name of the museum was changed to Turkish, and very sparse reference was made to anything Armenian, led many others to criticize the move as a public relations stunt. ${ }^{31}$

In September 2011, for the first time in a century or so, a church service was permitted to take place in Aktamar, with worshippers coming from Armenia, Istanbul, and a smattering from the diaspora. The now annual service was controversial, with many in the diaspora interpreting it as a shallow gesture. Yet for others, like the British Armenian historian Ara Sarafian, it is a meaningful and unprecedented first step upon which to build. ${ }^{32}$ Sarafian was at the helm of the publication of Aghtamar: A Jewel of Medieval Armenian Architecture, a bilingual Turkish and English book launched in Van and Istanbul in September 2010, ${ }^{33}$ where it attracted much discussion. These developments require a radical shift in mindset on the part of diasporans to comprehend the changing political landscape of Turkey, and also to capitalize on it, something that only small sections of the diaspora have thus far been able to do whole-heartedly. In general there is a cautious attitude to "wait and see" how things will actually pan out.

The current big project concerns the sixteenth-century Armenian Apostolic Cathedral Sourp (Saint) Giragos in Diyarbakır, the biggest Armenian church in the Middle East with a capacity of three thousand, which has lain in ruin for decades. Abdullah Demirtaş, Diyarbakır Sur's district mayor, seems sincerely committed to the principle of multiculturalism, through the resurrection of the different languages, places of worship and cultures of the city. ${ }^{34}$ This renovation has been mostly financed by the Armenian diaspora, through the initiatives of Vartkes Ergün Ayık, a businessman of Armenian origin from Diyarbakır, and Raffi Bedrosyan, an Istanbul Armenian now living in Canada. Bedrosyan explains, "The church, when reconstruction is completed, will become 
a historic destination of pilgrimage for all Armenians-a memorial and reminder of the past Armenian presence in Anatolia, and a hope for the future." ${ }^{35}$ At the heart of this project (and others like it) seems to be the need to validate (and consecrate) the past coexistence of Armenians alongside Turks, Kurds, Greeks, and others in Anatolian lands, rather than a realistic possibility of future such coexistence. It is important to recognize that in the wider Armenian-Turkish terrain, the struggle for negotiating coexistence is premised upon the perceived need to "prove" and document past coexistence, and the past lives of Armenians in these, their historic homelands. The fact that these past inhabitants were forcefully expelled or annihilated makes this an extremely charged and complex mission. It is understandable then that this project is best undertaken by Western diasporans who are relatively exempt from the powers and tentacles of the Turkish state, as opposed to Turkish Armenians who live with the possibility of being charged with "insulting Turkishness" or Islam. ${ }^{36}$

By using private funds, the church can be used as a consecrated house of worship, rather than a state-controlled museum like the Aktamar Church in Van, where only one annual religious ceremony is permitted. Although there is no Armenian community in Diyarbakır, a priest has been named by the Patriarchate to conduct occasional services for visitors. At the conclusion of the inaugural mass, Diyarbakır Mayor Osman Baydemir movingly addressed the congregation, in Armenian, and then Kurdish, Turkish, English, and Arabic: "Welcome to your home. You are not guests here; this is your home.... We all know about past events," he said, referring to the genocide, "and our wish is that our children will celebrate together the coming achievements." The Sourp Giragos project has also been controversial among some diasporans and locals, with the charge that it is supporting Turkish and Kurdish interests and is unnecessary as there are no Armenians left in the region.

In Istanbul I spent some time with a visiting group of diasporan Armenians who visited the Sourp Giragos Cathedral along with some Istanbul Armenians who helped facilitate the trip. Despite it being deemed a good thing, the renovation was criticized by several of them in that it (paraphrased) "is essentially like being given permission by the people who stole your house to renovate it and pay to visit it now and again while it continues to be in their possession." ${ }^{37}$ Beyond the sentimentalism of visiting "the old country" that was very much embraced by this group, this renovation was criticized, especially by the younger members of the group as a "PR exercise by the Kurdish community as a model of managing minorities." Rather than having significant impact for potential diasporan tourism the project was considered by one 
interviewee as "a propaganda device by the Kurds and very clever of them."

The Kurdish role in the Armenian-Turkish terrain has yet to be fully critically engaged with. The Kurdish leadership's acknowledgement of the role played by the Kurds in the genocide has affected the public discourse of some Kurdish activists, as well as leading to the uncovering of Armenian grandparents and unearthing of hidden identities. Some Kurds, as more recent victims of aggressive Turkish nationalism, have claimed solidarity with Armenians in a pan-minority movement in the democratization process (Neyzi and Kharatyan-Araqelyan 2010: 19-20). Yet from the perspective of many Istanbul Armenians, and especially diasporan Armenians, there is much that still needs to be addressed and reflected upon with greater critical honesty. There is also the sense that in the current political context Armenians lack agency and are reacting to initiatives and the unfolding agenda of others with uncertainty.

In recent years a tiny tourism industry run by Istanbul Armenians has started and is aimed at Western diasporans seeking to explore the lands from which their families originated pre-genocide. This phenomenon defies its small numbers in terms of impact in the diaspora communities from which the tourists come and the wider diaspora, as well as contributing to a change of attitudes towards the Turkish people (though not the state) of Western, mostly North American diasporans. Bakalian and Turan (2015) have written eloquently of the "subversive" quality of this tourism and its potential impact within the transnational space of Armenians, Turks, Kurds, and others, dedicated to uncovering, rediscovering, and remembering the Armenians of the Ottoman, particularly Anatolian, lands and centuries of coexistence.

\section{Negotiating Identity and Coexistence in Private and Public Spaces}

On the personal level interviewees shared many moving memories and encounters that they were in the process of reflecting upon from a more informed position. Thus the "everyday diplomacy" (Bryant this volume, p. 21) intrinsic to coexistence was constructed, narrated, and reflected upon in their own oral histories as the interviews unfolded.

Rana, a middle-aged Turkish woman, told the story of how as a young girl she had been invited to her friend's house where they had eaten pastries unfamiliar to her and colored, hard-boiled eggs. Only years later did she realize that this had been an Easter celebration and that the family had wanted to share the occasion with her but had been unable to 
tell her what it was, which would have meant revealing that they were Christians and Armenians. Rana remembers that "there was fear in the mother's eyes" and is able to reflect upon this with empathy and sadness.

As a filmmaker, Rana is now working on a film project of the "genocide trail" through Anatolia to the Levant. She recounted how, even before she gets the chance to ask, the elderly village and townspeople spontaneously share the fact that they once had Armenian neighbors and share stories of this past. It is an interesting realization that just as genocide survivors and their descendants are haunted by memories (personal and received), so too are the perpetrators and bystanders, and their descendants: "There was a desperate need to unburden themselves," Rana observed.

Pelin is a 62-year-old professional working in the media, having lived a typical Armenian life-born in Istanbul, living for long spells in London, the U.S., travelling regularly to her extended diaspora family and friends scattered in the Middle East, Paris, and North America, and finally resettled in Istanbul. She wryly observed, "Wherever you go you are a foreigner, even here where I am born." Her personal reflections, while representative of others of her age group, were also poignantly unique. When asked about what part her Armenian identity has played in her everyday life in her childhood, she shared:

My grandparents never told us their stories; we grew up without knowing these things. Now there are books and you can find out and learn. But in those days we knew nothing. We started questioning as we got older, but they always covered up and closed the subject. It was only after we moved to the U.K. that my grandfather told us the storieshe explained, so as not to make us turn against the country where we lived.

Many others spoke of this lack of information, that they were aware that there were secrets and hidden areas, and that they felt powerless to probe their elders, as there were subjects that were clearly off-limits and couched in fear and insecurity. This "subliminal knowledge" and the struggle to "piece together" a true version of the past was also something Turkish interviewees talked about, through their childhoods in the 1970s and 1980s where information within Turkey was limited. Silences and gaps featured in stories of the past of their elders and society more widely (Kasbarian and Öktem 2014).

Pelin and many other interviewees recalled having Turkish friends who were "like siblings," who protected her through trials like the reactions to the ASALA campaign ${ }^{38}$ in the 1970 s and 1980s. A Turkish family 
friend loaned her father the money for her brother to study in the U.S. after he was expelled from a Turkish university following a politically motivated quarrel with a professor. Indeed, she and others recounted many acts of extreme kindness and experiences bordering on familial closeness and intimacy. ${ }^{39}$ Implicit in these stories lies also a postcolonial dynamic-“the Armenian" as needing protection (from "bad Turks"?) and as infantilized in this encounter with "the Turk." By lacking agency and reduced to appealing to the good will of "good Turks," the Armenians continued the subjugated relationship from Ottoman times, and power structures were replicated in diluted forms, extending to Armenians' self-perception. ${ }^{40}$

Most interviewees, when asked if they had suffered discrimination, insisted that they had not, and yet within minutes remembered incidents from their childhood or even quite recently. Yet officially the answer seems to be "no," perhaps putting a brave face on, perhaps because these memories have been buried, maybe because they are commonplace occurrences to which one is immunized through time, or because there is no safe space to adequately express and articulate these experiences. The silencing of Armenian voices extends well beyond the genocide to contemporary experiences, where individuals lack the tools, the language, or the agency to own and express their experiences openly. The perceived impossibility of the coexistence of different narratives leads to the complete negation of the Armenian experience in the public sphere. The hegemonic narrative invalidates the Armenian experience to the extent that individuals have internalized this obliteration and are only able to extract and read their memories upon conscious, focused reflection, almost as if the stories that surface happened to someone else.

When contemplating coexistence, therefore, the coexistence of different narratives is at least as essential as physical coexistence. This marks a need for the radical reconceptualization of the master (nationalist) narrative, which can make space for the experience of others. Thus, stories like Çetin's or the subsequent Grandchildren (Altınay and Çetin 2011) are pioneering trajectories that are carving out a space in the public sphere for the possibility of counter-narratives from below and from the margins. The deconstruction and critique of the state master-narrative and the proliferation of other voices is an essential part of coexistence beyond "everyday diplomacy," underpinned by narratives that articulate and validate the subaltern experience. Spivak (1994) when asking "Can the Subaltern speak?" argues that a narrative of identity is an essential condition for agency and subjectivity. Arendt (1958) too stresses the need to hear one's story from others as key to constructions of identity and also to social relations. 
The lack of coexisting multiple narratives of identity led to deeply buried and ambivalent identities. Helin recounts that in 1960, when she was ten years old,

We had very good Turkish neighbours and we little girls used to play together every day. One day I went over as usual to her house, the little girl stood at the door and said "My grandmother does not want us to be friends anymore because you are Armenian." I didn't understand what this meant and went home crying, "what does being Armenian mean?"

Hagop, a 38-year-old man, recounted how as the only Armenian in high school he encountered some problems especially in the "ASALA days," was referred to as The Armenian, and was involved in a few fights. This resulted in him becoming withdrawn, something that seems to have become a permanent part of his character. He has two clear sets of friends that do not overlap-Turks and Armenians. He said "with some Turks when they find out you're Armenian they make banal and patronizing statements like 'they are good people,' and other Turks don't want to be friends once they find out."

This in-betweenness also applies to many individuals who are professionally active in mainstream society, where they have to negotiate (or hide) their Armenianness, and are also involved with the factious Armenian community, where they also have to manage their identities. Journalist Anahid, who has experienced extensive criticism from the various Armenian factions and their competing agendas, finds this is a tiring and demanding position: "I feel very lonely deep inside" and "sometimes I am more afraid of Armenians than Turks." This example also demonstrates the complexities of a layered identity, which can be stifling and restrictive when the state (and your community) deems you different and polices boundaries of identity and belonging. In the words of an interviewee in Beirut "it's impossible to escape my Armenian identity even if I wanted to." ${ }^{41}$

It became apparent through my interviews that individuals thought in terms of clearly defined spheres and the need to transgress and move from one to the other. There are a few ways in which these demarcations were blurred. For example all the Istanbul Armenians I met had Turkified surnames, and many had first names that were not obviously Armenian (like Helin). Schools reported a decrease each year of obviously Armenian-sounding first names. I was also told that some Catholic Armenians are using Turkish first names, the expressed aim being "to be totally invisible." Some Istanbul Armenians have two business cardsone with their Armenian name and another with the Turkish version. 
Many individuals recalled taking on a Turkish name when in the workplace-for example as boys working in the Grand Bazaar. Famous places like Ara Café owned by the noted Istanbul Armenian photographer Ara Güler also play on the fact that Ara means gap or interval in Turkish (the café is in a pedestrian side street), and most of the clientele are unaware that this is an Armenian establishment. These subtle forms of negotiation have the desired effect of being able to blend in and not attract unwanted attention. ${ }^{42}$

This sometimes extends to a kind of duality in that Armenian, if spoken at all, is confined to the house. Public life to all appearances must be Turkish, including names. Community identity therefore is limited to the private sphere, and often not even that. This divided self can result in feelings of exclusion from every side, being neither a Turk nor an Armenian, especially if one does not speak Armenian (an increasing trend) or practice the religion. Identities are complex and multi-layered but when politicized can result in profound disempowerment for those that fall outside the boundaries. This process affects individuals from a young age when they are grappling with their identity and sense of belonging. This often results in a compartmentalizing of identity, based on context. Neyzi and Kharatyan-Araqelyan (2010: 57) quote one such person from Sason in southeastern Turkey: "We are three things. We are Kurds at home, we speak Kurdish. Second, we are Turks at school, we speak Turkish. Third we are Armenians at the camp, we speak Armenian. We are Armenians in summer, Turks in school in winter, and Kurds at home."

\section{Negotiating Coexistence, Rights, and Belonging}

The Armenian Patriarchate of Istanbul (past and present) has traditionally kept a low profile, a policy considered to be the wisest in order to protect the community from nationalist backlashes. ${ }^{43}$ This extends to taking positions contrary to those of the diaspora, leading at times to a fraught relationship of mutual disappointment and misunderstanding. For example, genocide recognition is viewed fearfully by many Istanbul Armenians, including Patriarch Mesrob II, who conveyed this to the ambassador of the United States following the nationalist backlash after the murder of Hrant Dink (as leaked by Wikileaks in 2011). ${ }^{44}$ The diaspora in general is perceived as not being appropriately sensitive to the vulnerable nature of the Istanbul Armenians, who will ultimately bear the brunt of any repercussions, as they have previously.

Minority religious leaders at first seemed cautiously optimistic about the AKP government. There were initially a number of positive signs 
and gestures from the government, though these were on an "ad hoc basis, leaving open the possibility that they could be revoked or discontinued." ${ }^{45}$ Historically, the Armenian religious foundations and the Istanbul Armenian Patriarchate have faced great difficulty in preserving or protecting the church buildings and schools under their jurisdiction. There would be no permission from the government to carry out repairs or renovations. But this seems to have changed somewhat with the present government. The Deacon at the Patriarchate was cautiously optimistic about the future, saying that the current government has taken unprecedented steps, due to pressure from the EU as part of the conditions in the accession package. ${ }^{46}$ The Armenian Patriarchate has also lost its strength in the last few years as the Patriarch has been seriously ill and the institution has been left in a kind of limbo with squabbles among the community as to the way forward. Since 2008 Archbishop Aram Atesyan has been the acting patriarch, his appointment a point of great contention in the community.

The government has recently announced its plans to return the properties confiscated after 1974-a move deemed "necessary but insufficient" but hailed as a magnanimous gesture by the state itself. In fact it is also a shrewd and strategic act to avoid having to pay compensation through the European Court of Human Rights, and one undertaken with pressure from both the EU and the U.S. The present government has pledged to return 162 of the 1,410 assets of minorities confiscated in 1974. The state closed down minorities' seminaries so clergy cannot be trained in Turkey, and there are currently only twenty-six Armenian Orthodox priests in the whole of Turkey (U.S. Commission on International Religious Freedom, 2012 Annual Report). These restrictive measures seriously threaten the long-term viability of the Armenian community as a religious community.

There are also thought to be up to 25,000 Armenians from Armenia living illegally in Istanbul, forced to migrate temporarily for economic reasons. ${ }^{47}$ A 2009 study carried out for the Eurasia Partnership Foundation (Ozinian 2009) reported that most illegal Armenian migrants in an interview pool of 150 originated from the northwestern Armenian region of Shirak, the site of the devastating 1988 earthquake. Of the respondents 94 percent were women employed in domestic work. Prime Minister Erdoğan has made threats to expel illegal Armenian migrants several times, claiming that there are close to 100,000. These comments are seen as retaliation for Armenia's push for recognition of the genocide. Alongside this regressive talk, there are some promising signs, too. For example, the children of the thousands of illegal Armenian workers have until recently not been allowed to attend (Armenian) community 
schools. However in 2011 the government announced that this ban would be lifted so long as the children did not receive any official documents that might facilitate their long-term stay in Turkey (Ozinian 2011).

Although this is hailed as a step forward by the Armenian community, there are also fears about the already-limited resources of the fourteen primary schools and five high schools in Istanbul being further stretched. This concerns not just material resources but also teachers. The general trend is acknowledged to be one of decline, both in terms of enrollment numbers and in terms of the quality of Armenian education. The schools must follow the Turkish curriculum in full, while allowing for classes in Armenian language and literature. However, they are not permitted to recruit teachers from outside Turkey and hence the standard of teaching of Armenian is limited. They are only permitted to teach official Turkish history. Furthermore, all minority schools have a Turkish vice-principal appointed by the state to act as the "eyes and ears" of the state and make sure they stay in line. This role is apparently being taken less seriously in schools in recent years, but it is still a reminder of the watchful state, along with the images of Ataturk adorning every classroom. The fact that there is no Armenian Studies at university level in Turkey means that the schools are forced to employ teachers of Armenian language who are merely high school graduates, thereby also compromising the standard of instruction. The general decline of the Armenian language in Turkey is also evident in the reduced number of pages published in Armenian of Agos. ${ }^{48}$ This has led to much soul-searching among many in community leadership roles, about "what makes us and keeps us Armenian, just language ... or religion or something else?” Armenian schools are full of pupils who "are already very Turkified, speak Armenian with Turkish accents, sometimes struggling to speak it at all." ${ }^{49}$

Whether change should come from above or below is a subject of much discussion. Traditionally the community organizations have kept a low profile and have only very cautiously made the slightest responses to adverse state policy. This docile position was taken in order to protect and preserve an already threatened and fearful community, thereby leading to a culture of meekness. Some groups and individuals are now arguing that the community needs to take on an active role in making changes rather than just accepting things. One primary school principal talked too of a "self-censorship" by the community that is entrenched in its ways, exuding inertia and acceptance of the situation. This bind also results in contradictory positions. For instance, wealthier patrons of the schools gift money but do not send their children there, preferring to send them to private, more prestigious schools, where the standard 
of education is higher. So although they are committed to (financially) supporting community institutions, they are not so invested personally. The same principal and others talked about the need to be "clever and creative" in their teaching - to bring in Armenian history in an oblique or roundabout way, as it is not permitted to be taught. ${ }^{50}$ In the case of the Church, Armenian history is brought in where possible under the guise of religious lessons, another example of the subversive "weapons of the weak" (Scott 1990) that subaltern groups use to resist the power of, in this case, the authoritative state.

\section{Contemplating Coexistence, Beyond "Tolerance”}

One major area of contention with regard to the coexistence of the minorities in Turkey is the properties of their foundations, religious and secular. These valuable and impressive properties and their extent hark back to a period where there were significant minority populations in Turkey, and in Istanbul in particular. Akgönül (2013: 91), considers the foundations as "the most important element that guarantees the existence of non-Muslim minorities in Turkey" and the foundation system as "a tether for minority institutions-religiously and symbolically as well as financially" Historically there have been severe restrictions on the minorities with regard to these properties, their ownership, use and maintenance. In 2008 the Foundations Law was amended in several ways, including the possibility of applying for the return of minorities' property confiscated by the Turkish state, though the scope and mechanisms of the law are limited and a small number of properties have been returned to the religious foundations thus far.

Lakis Vingas is the minority representative on the General Directorate Council for Foundations, representing the 162 minority foundations in Turkey. He is the first ever such representative, serving alongside fourteen others representing the non-minorities, since December 2008. For the first time in the history of the republic a representative has been appointed especially for minorities, and his position has been a difficult one, balancing the suspicions and criticisms of the directorate on the one hand and the minority foundations on the other. He believes that the time is right for minorities to be at the forefront of the demand for change:

I know there is progress because I know both Turkeys. I know from where to where (we have come).... The progress is huge, but we have no time, we are tired. We cannot have more suffering. The new gen- 
erations will not work as we used to. We need to be demanding, to be claiming-look at how far the Kurds have progressed in this compared to ten years ago and they say still it is not sufficient. Things need to happen quickly!

The Ottoman principles of "tolerance" and "protection" with which the religious minorities are still approached sound anachronistic and potentially offensive. As discussed by Bryant in the introduction to this volume, etymological meanings of tolerance carry a sense of burden and forbearance (Kaya and Harmanyeri 2012: 398). In the Ottoman Empire tolerance simply meant a lack of persecution, so long as the subjects obeyed the laws and obligations set out through the dhimmi system of governing. Kaya and Harmanyeri (2012: 414) talk about the myth of tolerance that functions to "conceal the mistreatment of ethno-cultural and religious minorities." "Tolerance" as a political principle has been criticized by minorities for its grudging acceptance of difference as opposed to the possibility of incorporating and celebrating diversity (Kasbarian 2009; see also Duru this volume). In the words of one middle-aged interviewee, "I don't want to be tolerated, private, and special, I want to be equal. I don't need to be treated as a piece of antique that needs to be protected.... If we don't feel equal or if they don't see us as equal we cannot progress!"

Formally, minorities in Turkey have the status of "equal citizens," yet they cannot use the same rights granted by this citizenship, with discriminatory practices commonplace in the institutional, political and social realms. Citizenship is increasingly viewed beyond its legal definition, as "a set of discourses and practices that are translated unevenly across unequal social groups and local contexts" and as a "hegemonic strategy" that "works to define these groups or localities, to fix the power differentials between them, and then to naturalize these operations" (Secor 2004: 354). The prospect of EU membership has acted as a reforming project in Turkey, as it has in other candidate countries (Kasbarian 2009), gradually addressing restrictions upon minorities. Since 2002 Turkey has undergone a serious program of reform, but this has fallen short of addressing non-Muslim minorities' demands and rights (Goltz 2006, 2013). While meeting EU standards is a promising means of promoting freedom, democracy, and human rights, legislation alone cannot change deep-seated attitudes and historic grievances. What we are witnessing in Turkey is the potential for redefining Turkish identity, to reconsider the question of "who is a Turk"-and the creation of a Turkey not for ethnic Turks but for all citizens of Turkey, regardless 
of ethnicity or religion. Though there have been a few overtures by the state, ${ }^{51}$ window-dressing gestures fall short of the fundamental changes that are necessary. What is needed is for the state to redefine and create meaningful and sufficiently open categories of identity and belonging, and for policy to reinforce the gradual advances in civil society.

Clearly, genuine coexistence that fully acknowledges Others needs to go beyond "tolerance." For genuine coexistence there needs to be a structural framework that underpins equality and respect for diverse groups (and allows for their internal differences). For this the work of civil society is essential in changing attitudes, opening up spaces for discussion and expression, and challenging the nationalist and exclusionary foundations of the Turkish state. Acknowledging different narratives may liberate people from being forced to inhabit fixed categories of identities ascribed by competing nationalizing projects, and allow for a reconceptualization of identity (on all levels). Where nationalizing projects and practices seek to enclose and confine identities, the reality of lived experience, of coexistence despite real and perceived difference, is testimony to a different narrative and with it the possibility of a redemptive post-nationalist future. The legacy of the genocide and its continuing denial make the Armenian existence in Turkey highly politicized. Yet despite state denialism and a wider climate of political regression and polarization, there continue to be significant developments at the level of civil society (Kasbarian and Öktem 2014). Intrinsic to this process is the recognition of different narratives and of being able to articulate and own one's own story. That this is a mutually reinforcing project, and needs to be underpinned by a transformation in the state narrative (and structures) is a given. Only then can Istanbul Armenians speak and act with confidence and dignity as Armenians and Turkish citizens.

Sossie Kasbarian is Lecturer in Middle East Politics at Lancaster University. She is co-editor of the book Diasporas of the Middle East - Contextualising Community (with Anthony Gorman, Edinburgh University Press, 2015) and author of several articles relating to the Middle East and Diaspora Studies. She is co-editor (with Kerem Öktem) of the special issue of the journal Patterns of Prejudice entitled Armenians, Turks and Kurds Beyond Denial (Vol. 48, May 2014), as well as co-editor (with Kerem Öktem) of the forthcoming special issue of the journal Nationalities Papers, entitled, Possibilities of a shared memory: Reflecting on "Travails de memoire", civil society activism, nation-building and contestation in Armenia, Turkey and the Diaspora in 2015. 


\section{Notes}

My thanks to the editor and two anonymous reviewers for insightful and helpful feedback on this chapter.

1. This chapter was written before the dramatic downward spiral in Turkey and the polarization of Turkish society, exemplified by the Gezi Park protests of 2013; the witchhunt against the AKP's former Islamist allies, the Hizmet movement of US-based cleric Fethullah Gülen; the clear re-emergence of ultra-nationalists and the 'deep state' in violent attacks against opponents of the AKP, and the complete collapse of the uneasy peace with the PKK in 2015. There has been an escalating crackdown on basic freedoms and rights, to the extent that a recent report by the senior Turkey researcher at Human Rights Watch stated, "Human rights and the rule of law in Turkey are at the worst level I've seen in the 12 years I've worked on Turkey's human rights." (Emma Sinclair-Webb, "No EU, Turkey is not safe for everyone" 23 October 2015, Open Democracy, https://www.opendem ocracy.net/emma-sinclair-webb/no-eu-turkey-is-not-safe-for-everyone)

2. This chapter draws upon one month of fieldwork and over thirty formal and informal interviews in Istanbul in June-July 2011. This included (Armenian) community leaders and activists, as well as a representative crosssection of the Armenian community, spanning different ages, socio-economic and educational backgrounds, and degrees of affiliation and involvement with the Armenian community. All names (unless speaking in an official capacity) have been changed to protect anonymity.

3. This figure refers to Turkish citizens. It does not count the significant numbers of Armenians from Armenia working in Turkey as seasonal or more long-term economic migrants, usually illegally. This has been a subject of media and political concern, as well as being used as a political tool on more than one occasion. See section below.

4. The 2010 estimates from the U.S. State Department include 23,000 Jews; 15,000 Syriac Christians; 10,000 Baha'is, 5,000 Yezidis; 3,300 Jehovah's Witnesses; 3,000 Protestants; and 1,700 Greek Orthodox.

5. For an analysis of the Treaty of Lausanne and "Protection of Minorities" see Akgönül (2013: 65-101).

6. For a comprehensive analysis of the campaign and its legacies, see Aslan (2007).

7. Göçek's latest book focusses on this. (Fatma Müge Göçek [2015], Denial of Violence - Ottoman Past, Turkish Present, and the Collective Violence against the Armenians 1789-2009. Oxford and New York: Oxford University Press.)

8. Stanley Fish (1997: 1) says, "Boutique multiculturalism is characterized by its superficial or cosmetic relationship to the objects of its affection. Boutique multiculturalists admire or appreciate or enjoy or sympathize with or (at the very least) 'recognize the legitimacy of' the traditions of cultures other than their own; but boutique multiculturalists will always stop short 
of approving other cultures at a point where some value at their center generates an act that offends against the canons of civilized decency as they have been either declared or assumed."

9. http://www.worldbulletin.net/news/134778/turkeys-armenians-suggest-er dogan-for-nobel-prize

10. Erdoğan went on the Charlie Rose show that same week and claimed that if there had been a genocide there would not be any Armenians still living in Turkey, thereby exposing the way that this community are held hostage and employed instrumentally by the state, and the extremely precarious position they find themselves in. See http://www.charlierose.com/watch/60382027

11. http://www.basbakanlik.gov.tr/Forms/_Article/pg_Article.aspx?Id=e11 bde56-a0b7-4ea6-8a9a-954c68157df9.

12. Personal communication, June 2014.

13. See, for example, Bloxham (2005).

14. The most significant include Taner Akçam, Fatma Müge Göçek, Baskın Oran, Uğur Ümit Üngör, Kerem Öktem, Ayşe Kadioğlu, Cengiz Aktar, Ayşe Gül Altınay, among others. There is also a growing new generation of scholars whose work follows these pioneers and promises to be very exciting.

15. The instigators were scholars Ahmet İnsel, Baskın Oran, Cengiz Aktar, and journalist Ali Bayramoğlu. The campaign was denounced by the Turkish state and nationalists, and criticized for not going far enough by others. For a critical reading of the campaign see Erbal (2012).

16. Interview with Ayse Gül Altınay, Istanbul, June 2011.

17. The founder of the union, Mihran Gültekin, says that he knew that he was Armenian since he was seven but only managed to reclaim his identity formally at the age of fifty. His 21-year-old son has also been converted, and is baptized Hrant. Over 200 families in the region have reclaimed their Armenian identity in recent years. Gültekin claims that 75 percent of the Dersim population is composed of converted Armenians. (Dersim is a region of eastern Turkey that includes Tunceli Province, Elazığ Province, and Bingöl Province.) See for example, http://massispost.com/archives/ 1752.

18. The conference on Islamized Armenians was organized by the History Department of Boğaziçi University, the Hrant Dink Foundation and the Charitable Association of Armenians from Malatya (HAYDer), and held in Istanbul on 2-4 November 2013. For links to the conference and related pieces, see "Conference on Islamized Armenians," 14 November 2013, available on the Hrant Dink Foundation website (www.hrantdink.org/?Detail $=753 \&$ Lang=en) $($ accessed 2 April 2014).

19. Agos (meaning "furrow" in Armenian) is an Armenian weekly newspaper published in Istanbul since 1996. It has both Armenian and Turkish pages (see http://www.agos.com.tr). Hrant Dink was one of its founders and chief editor until his murder in January 2007.

20. Interview, Istanbul, June 2011.

21. This theme is eloquently explored in Anahit (2014). 
22. For a discussion of the deep state in contemporary Turkey, see Karabekir Akkoyunlu (2015) “Old Demons in New Faces - The 'Deep State' meets Erdogan's 'New Turkey”' (October 25, 2015, The Huffington Post http:// www.huffingtonpost.com/karabekir-akkoyunlu/old-demons-in-new-fac es-t_1_b_8383086.html

23. U.S. Commission on International Religious Freedom 2012 Annual Report.

24. See for example, "Sevag Balıkçı was Shot By Mistake, Court Rules" by Ekin Karaca, http://www.bianet.org/english/minorities/145402-sevag-bal ikci-was-shot-by-mistake-court-rules.

25 This was apparent in the run-up to the commemoration of the centenary of the Armenian Genocide in April 2015. See Kasbarian and Öktem, 2016 (forthcoming).

26. There are currently a number of successful Armenian-Turkish initiatives at the level of civil society aimed at encouraging relations between the two countries. For instance, the Armenia-Turkey Cinema Platform (ATCP) organizes meetings between film-makers of both countries and explores themes of identity and common roots. ATCP was founded through the cooperation of Anadolu Kültür and Golden Apricot Yerevan International Film Festival in 2008 to encourage a common network and projects, and has been supported by organizations including USAID, the Eurasia Partnership Foundation, the International Center for Human Development, the Yerevan Press Club, and the Union of Manufacturers and Businessmen of Armenia.

27. http://www.anadolukultur.org/

28. Interview with Osman Kavala, Istanbul, June 2011.

29. The Armenian Institute organized the exhibition and cultural program, sponsored by the St. Sarkis Charity Trust and Diana and Panos Katsouris. http://www.soas.ac.uk/gallery/mydearbrother/

30. For the vision and activities of the Foundation see http://www.hrantdink. org/index.php?About=18\&Lang=en

31. The controversial cross was finally erected on the top of the church on 2 October 2010.

32. Book Launch in Hai Doon (Armenia House), London, October 2010.

33. Coproduction between Gomidas Institute in London and Birzamanlar Yayıncılık in Istanbul.

34. For which he has had charges brought against him numerous times. Located in the city's Gavur (infidel) district, St. Giragos is close to St. Peter's Chaldean Catholic church (also undergoing restoration), a mosque, the Diyarbakır Protestant Church, and a synagogue, with construction plans for places of worship along the same street for Alawites and Yezidis. Mayor Demirtaş's vision is to make Diyarbakır "Anatolia's Jerusalem."

35. "Evolving Armenian Realities and the Surp Giragos Dikranagerd Church" by Raffi Bedrosyan. Posted on July 1, 2011, http://www.armenianweekly .com/2011/07/01/evolving-armenian-realities-and-surp-giragos-dikranag erd-church. 
36. The latest victim of this is the writer and linguist Sevan Nişanyan (May 2013), sentenced to prison for alleged blasphemy, http://www.globalpost .com/dispatch/news/regions/europe/turkey/130523/sevan-nisanyan-turk ish-armenian-blogger-jailed-blasphemy.

37. Informal conversations, Istanbul, July 2011.

38. The Armenian Secret Army for the Liberation of Armenia (ASALA) launched a violent campaign against Turkish diplomats from the late 1970s to the early 1990s. For an overview see Dugana, Huang, LaFree, and McCauley (2008). For a reading of these groups as part of a third world liberation movement and their mission to awaken the Armenian diaspora, see Tölölyan (1988).

39. See also Anahit 2014.

40. In Ottoman times, the Armenians were known as "the Loyal Millet" (Millet-i Sadika).

41. Interview, Beirut, March/April 2003. In Lebanon, the "country of minorities," the Armenian Catholics, Orthodox, and Protestants are among the eighteen state-recognized religious minorities, with the "private domain" being conducted by religious leaders and within the arena of the community.

42. Not one of my interviewees (apart from the few that spoke in an official capacity) was willing to be recorded, revealing an insecurity and fear of repercussions.

43. In contrast, the Greek Patriarch Bartholomew is viewed as strong and outspoken in a way that Armenian equivalents feel they cannot be. This is explained not just by personality but also by the relative strength and importance of Greece compared to Armenia, as well as the much more cordial links.

44. For full text from Wikileaks (based on a meeting between Patriarch Mesrob II and then-Deputy U.S. Assistant Secretary of State for European and Eurasian Affairs Matthew Bryza in February 2007) and analysis see Barsoumian (2011).

45. U.S. Commission on International Religious Freedom, 2012 Annual Report.

46. Interview at the Patriarchate, Istanbul, June 2011.

47. See for example, Grigoriyan and Hayrapetyan (2011).

48. Interview with Agos journalists, Istanbul, June 2011

49. Interview, Armenian high school principal, Istanbul, June 2011.

50. Interview, Armenian primary school principal, Istanbul, June 2011.

51. Examples include the appointment of Armenians in minor official posts.

\section{References}

Akçam, Taner. 2004. From Empire to Republic: Turkish Nationalism and the Armenian Genocide. New York: Zed Books.

Akgönül, Samim. 2013. The Minority Concept in the Turkish Context. Leiden: Brill. 
Akyol, Tuba. 2005. “Özür Dilerim.” Milliyet Pazar, 19 March 2005 (available on the publisher's website: http://www.metiskitap.com/Metis/Catalog/Text/ 61202).

Altınay, Ayşe Gül. 2006. "In Search of Silenced Grandparents: Ottoman Armenian Survivors and Their (Muslim) Grandchildren." In Der Völkermord an den Armeniern, die Türkei und Europa=The Armenian genocide, Turkey and Europe, ed. H.L. Kieser and E. Plozza, 117-32. Zürich: Chronos

Altınay, Ayşe Gül, and Fethiye Çetin. 2011. Torunlar [Grandchildren]. Istanbul: Metis Publications.

Anahit, Helin. 2014. "Bounded Totalities, Collective Inventions: Exploring Identity and Cultural Assumptions in Turkey through the Armenian Experience." In Patterns of Prejudice special issue Beyond Denial: Armenians and Turks, One Hundred Years Since 1915, 48(2): 201-222.

Arendt, Hannah. 1958. The Human Condition. Chicago: University of Chicago Press.

Aslan, Senem. 2007. "Citizen Speak Turkish! A Nation in the Making." Nationalism and Ethnic Politics 13(2): 245-72.

Bakalian, Anny, and Zeynep Turan. 2015. "Diaspora Tourism and Identity: Subversion and Consolation in Armenian Pilgrimages to Eastern Turkey." In Diasporas of the Modern Middle East - Contextualising Community, ed. A. Gorman and S. Kasbarian, p. 173-211. Edinburgh: Edinburgh University Press.

Barsoumian, Nanore. 2011. "Wikileaks: Turkey's Armenians Fearful of 'Violent Backlash,' Facing Uncertain Future.” Armenian Weekly, 10 September 2011, http://www.armenianweekly.com/2011/09/10/wikileaks-turkeyarmenians/.

Bilefsky, Dan. 2010. "Secrets Revealed in Turkey Revive Armenian Identity." The New York Times, 10 January 2010.

Bloxham, Donald. 2005. The Great Game of Genocide: Imperialism, Nationalism and the Destruction of the Ottoman Armenians. Oxford: Oxford University Press.

Braude, Benjamin, and Bernard Lewis, eds. 1982. Christians and Jews in the Ottoman Empire. New York: Holmes \& Meier Publishers Inc.

Çetin, Fethiye. 2004. Anneannem [My grandmother]. Istanbul: Metis Yayinlari.

- 2008. My Grandmother, trans. Maureen Freely. London: Verso.

Dugana, Laura, Jullie Y. Huang, Gary LaFree, and Clark McCauley. 2008. "Sudden Desistance from Terrorism: The Armenian Secret Army for the Liberation of Armenia and the Justice Commandos of the Armenian Genocide." Dynamics of Asymmetric Conflict: Pathways Toward Terrorism and Genocide 1(3): 231-49.

Erbal, Ayda. 2012. "Mea Culpas, Negotiations, Apologias: Revisiting the 'Apology of Turkish Intellectuals." In Reconciliation, Civil Society and the Politics of Memory: Transnational Initiatives in the 20th and 21st Century, ed. B. Schweilling, p. 51-94. Bielefield: Transcript.

Erbal, Ayda, and Talin Suciyan. 2011. "One Hundred Years of Abandonment." 
The Armenian Weekly, April 2011, http://www.armenianweekly.com/2011/ 04/29/erbal-and-suciyan-one-hundred-years-of-abandonment.

Fish, Stanley. 1997. "Boutique Multiculturalism, or Why Liberals are Incapable of Thinking About Hate Speech." Critical Inquiry 23(2): 378-95.

Göçek, Fatma Müge. 2007. "Furor against the West: Nationalism as the Dangerous Underbelly of the Modern Turkish Republic." In Nationalism and European Integration: The Need for New Theoretical and Empirical Insights, ed. I.P. Karolewski and A.M. Suszycki, 167-79. New York: Continuum International Publishing.

— . (2006) 2013. "Defining the Parameters of a Post-Nationalist Turkish Historiography Through the Case of the Anatolian Armenians: Going Back to 1902." In Turkey Beyond Nationalism-Towards Post-Nationalist Identities, ed. H.L. Kieser, 85-103. London: I.B. Tauris.

Göçek, Fatma Müge. 2015. Denial of Violence - Ottoman Past, Turkish Present, and the Collective Violence against the Armenians 1789-2009. Oxford and New York. Oxford University Press.

Goltz, Gabriel. (2006) 2013. "The Non-Muslim Minorities and Reform in Turkey." Turkey Beyond Nationalism-Towards Post-Nationalist Identities, ed. H.L. Kieser, 175-82. London: I.B. Tauris.

Gorman, Anthony, and Sossie Kasbarian, eds. 2015. Diasporas of the Modern Middle East - Contextualising Community. Edinburgh: Edinburgh University Press.

Grigoriadis, Ioannis N. 2011. "Redefining the Nation: Shifting Boundaries of the 'Other' in Greece and Turkey.' Middle Eastern Studies 47(1): 16782.

Grigoryan, Marianna, and Anahit Hayrapetyan. 2011. "Turkey: Armenian Illegal Migrants Put National Grievances Aside for Work." Eurasianet, 2 September 2011, http://www.eurasianet.org/node/64116.

Judt, Tony. 2010. The Memory Chalet. New York: Vintage.

Kadığlu, Ayşe. 2007. "Denationalization of Citizenship? The Turkish Experience." Citizenship Studies 11(3): 283-99.

Kardam, Nükhet. "Who is a Turk?” Today's Zaman, 29 August 2011.

Kasbarian, Sossie and Kerem Öktem. 2016. Special issue of the journal Nationalities Papers, Possibilities of a shared memory: Reflecting on "Travails de memoire", civil society activism, nation-building and contestation in Armenia, Turkey and the Diaspora in 2015.

Kasbarian, Sossie, and Kerem Öktem. 2014. "Subversive Friendships: Turkish and Armenian Encounters in Transnational Space." Patterns of Prejudice special issue Beyond Denial: Armenians and Turks, One Hundred Years Since 1915 48: 2: 121-46.

Kasbarian, Sossie. 2009. "The Armenian Community in Cyprus at the Beginning of the 21st Century: From Insecurity to Integration." In The Minorities of Cyprus: Development Patterns and the Identity of the Internal-Exclusion, ed. A. Varnava, N. Koureas, and M. Elia, 175-91. Newcastle-upon-Tyne: Cambridge Scholars Publishing. 
Kaya, Ayhan, and Ece Harmanyeri. 2012. “Turkey." In Addressing Tolerance and Diversity Discourses in Europe: A Comparative Overview of 16 European Countries, ed. R. Zapata-Barrero and A. Triandafyllidou, p. 397-415. Barcelona: CIDOB, Barcelona Centre for International Affairs.

Keyder, Çağlar, ed. 1989. Türkiye'de Devlet ve Sinıflar [State and the Classes in Turkey]. Istanbul: İletișim.

Kieser, Hans-Lukas, ed. 2013. Turkey Beyond Nationalism-Towards PostNationalist Identities. London: I.B. Tauris.

Mills, Amy, James A. Reilly, and Christine Philliou. 2011. "The Ottoman Empire from Present to Past: Memory and Ideology in Turkey and the Arab World." Comparative Studies of South Asia, Africa and the Middle East 31(1): 133-36.

Mills, Amy. 2008. "The Place of Locality for Identity in the Nation: Minority Narratives of Cosmopolitan Istanbul." International Journal of Middle East Studies 40: 383-401.

- 2010. Streets of Memory: Landscape, Tolerance and National Identity in Istanbul. Athens, GA: University of Georgia Press.

- 2011. "The Ottoman Legacy: Urban Geographies, National Imaginaries, and Global Discourses of Tolerance." Comparative Studies of South Asia, Africa and the Middle East 31(1): 183-95.

Neyzi, Leyla, and Hranush Kharatyan-Araqelyan. 2010. Speaking to One Another: Personal Memories of the Past in Armenia and Turkey. Bonn: Des Deutschen Volkshochschul-Verbandes.

Oğuz, Aziz. 2012. “Turkey's Last Armenian Schools." Le Monde Diplomatique (English edition), 14 December 2012.

Öktem, Kerem, Ayşe Kadığlu, Mehmet Karlı, eds. 2012. Another Empire? A Decade of Turkey's Foreign Policy under the Justice and Development Party. Istanbul: Istanbul Bilgi University Press and SEESOX Oxford.

Ozinian, Alin. 2010. "Identifying the State of Armenian Migrants in Turkey." Available at http://www.epfound.am/files/epf_migration_report_feb_2010 _final_march_5_1.pdf.

- 2011. "The Children of Istanbul's 'Illegal' Armenians; Lost in the Educational Shuffle Up Until Now." Today's Zaman, 21 September 2011, http://www.todayszaman.com/newsDetail_getNewsById.action;jsessionid =E1C727974FFACAD7FA2215A47189A803?load=detay\&newsId=257545.

Secor, Anna. 2004. "There is an Istanbul that Belongs to Me: Citizenship, Space and Identity in the City." Annals of the Association of American Geographers 94(2): 352-68.

Scott, James C. 1990. Weapons of the Weak: Everyday Forms of Peasant Resistance. Delhi: Oxford University Press.

Spivak, Gayatri. 1994. "Can the Subaltern Speak?" In Colonial Discourse and Post-Colonial Theory: A Reader, ed. P. Williams and L. Chrisman, 66-111. New York: Columbia University Press.

Suciyan, Talin. 2012. “Armenian Representation in Turkey?” The Armenian Weekly Magazine, April 2012, http://www.armenianweekly.com/2012/06/ 12/suciyan-armenian-representation-in-turkey. 
Tölölyan, Khachig. 1988. “Book Review." Conflict Quarterly 8: 101-5.

Türkmen-Dervişoğlu, Gülay. 2013. "Coming to Terms with a Difficult Past: The Trauma of the Assassination of Hrant Dink and Its Repercussions on Turkish National Identity." Nations and Nationalism 19(4): 674-92.

Üngör, Uğur Ümit. 2014. "Lost in Commemoration: The Armenian Genocide in Memory and Identity." In Patterns of Prejudice special issue Beyond Denial: Armenians and Turks, One Hundred Years Since 1915 48(2):147-66.

U.S. Commission on International Religious Freedom, 2012 Annual Report, http://www.uscirf.gov/images/Annual\%20Report\%20of\%20USCIRF\%20 2012(2).pdf. 
2. Chapter $9 \cdot 6$

\title{
A Conflict of Spaces or of Recognition?
}

\author{
Co-presence in Divided Jerusalem
}

SYLVAINE BULLE

\begin{abstract}
$T_{1}$
he breakdown of the peace accords, the resumption of the Intifada in 2000, and the numerous military incursions that followed marked a new phase in the Israeli-Palestinian conflict. Today, Jerusalem is a city cut in two by a security barrier-called a wall by the Palestinians - whose conception and ongoing construction was initiated by the State of Israel in 2006. With the decision to build a security barrier cutting Jerusalem in two-separating the Palestinians of East Jerusalem from other Palestinians and from Israeli citizens-Israel created a visible and impermeable border and in so doing, affirmed the spatial delimitation of an enemy territory behind it (Brown 2010). The security barrier acts to redefine a symbolic and spatial nomos ${ }^{1}$ (Schmitt 2003), and to safeguard the limits between Israel and the surrounding world: a world conceived as a threat.

In this context of separation, studies of the Israel-Palestine conflict for the most part operate under a theory of simple domination: a primary relation between dominators (Israeli) and those who are dominated (Palestinians), where transgression and resistance can only be understood as interiorization or some continuation of power by which the subject is stripped of subjectivity, thus making it impossible for a communal world to exist. The exteriorization of power assumes that no description of relations is possible that is unrelated to government techniques, to juridical means of exception from the common law, to modes of exclusion that operate through enclosure within Palestinian enclaves, or else the symbolic violence of the Israeli state.
\end{abstract}

The approach elaborated here is different. It proposes to consider the reality of separation through the observation of Jerusalem and its bor- 


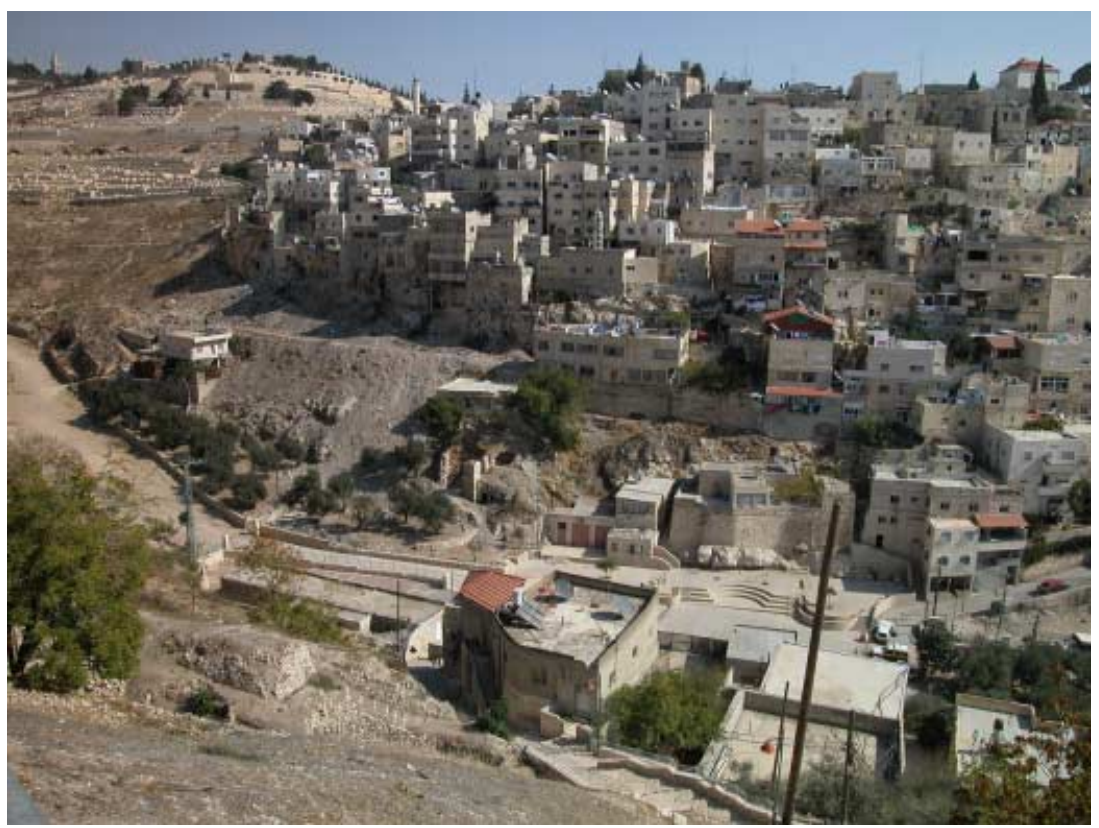

Figure 9.1. Confrontation in Jerusalem: Mt. of Olives and East Jerusalem (photo by Sylvaine Bulle).

ders and walls. Without discounting the real constraints that have been created by the wall and its limits, this approach also considers subtle interactions between segmented populations (Israeli and Palestinian, Jewish and Arab) and the ways in which these interactions shape links between these social worlds. We will thus highlight examples of acts of communication and the mechanisms actors use to continue exchange at the edges of Jerusalem and between Jerusalem and the Palestinian territories. These operations may seem improbable or minor. But is it possible to find a model of balanced justice that assumes this state of facts, and the possibility of exchanging within a space that is fragmented and conflictual? Does not the vision of a politics of co-presence offer an alternative to theories and abstract political scenarios in the search for a solution to the spatial and inter-community conflict of Jerusalem?

\section{Co-presence or Separation? Holding onto Contiguity at Any Price}

What is this security barrier called a wall in the case of East Jerusalem? It is a militarized and social frontier. Certain people find themselves within 
the limits of Jerusalem (on the "good" side of the wall, within the perimeter of the Municipality of Jerusalem). They benefit from their status as residents of Jerusalem, a kind of socio-economic citizenship-providing Israeli social rights to education, health, the right to live and circulateeven if the accordance of residency has been considerably limited since the creation of the barrier. Family reunification is difficult. Residency status can be taken away from Palestinians from Jerusalem who leave the territory. The de facto acquisition of residency status for a wife and children no longer applies. ${ }^{2}$ On the other side of the wall stretches a gray zone. In this zone, despite being a dependent part of Jerusalem, residents are now under the control of Palestinian institutions, and as such, lack the possibility of exchange with those who find themselves on the opposite side of the wall. The wall has thus instituted a within and a without; it has redefined social relations and fixed an internal limit to the Palestinian community by distinguishing those who are included and those who are shut out, deprived of their rights at the periphery of the city.

Rather than aiming here to make an argument about the nature of Israeli sovereignty in Jerusalem - the exercise or not of the "state of exception" (Agamben 1998) - this chapter shows how different interactions exist along the barrier and how these interactions coexist with the idea of enclosure itself. These situations provide ways to think about the politics of separation, modes of thinking that do not operate through a strict vision of vertical power as it is understood in radical critical theory (in political science or geography). ${ }^{3}$ What I would like to examine is less a theory of exception (defined as the suspension of rights and of the frontier between within and without) and more a theory of heteronomy (Simmel 1999). Heteronomy is usually defined as influence over one's will, i.e., less than full autonomy. For Simmel, however, heteronomy has a dual face: it is a form of interdependence, defined by both autonomy and constraint, and this may be figured by spatial frontiers. The tension between the two polarities of freedom and constraint may be seen as structural (Simmel says "grammatical") elements of social life. In Simmel's reasoning, parts are isolated from the whole while still belonging to that whole. Individuals or groups, even if they are confined by physical boundaries, react to each other because there is a totality of meaningful effects that both emanates from and influences them. The everyday constraint on autonomy is also a theory of contiguity or co-presence.

In their approach to social theory, the sociologists of the Chicago School (Grafmeyer and Joseph 1984) also emphasized this aspect and define what they call an "urban mentality." For Wirth and Park, a citizen is understood as a person who is able to communicate, able to distrib- 
ute attention, and to live at the same time in several worlds, between or among multiple spheres of belonging. By extension-and as Simmel (1971) emphasizes-the most significant aspect of the metropolis lies in this contiguity or co-presence upon which urban life is erected. Despite its division, co-presence also defines the city Jerusalem. The physical "contiguity" of different communities (Jews, Arabs, and other minorities) gives the city its psychological and aesthetic foundation. The atmosphere of the city depends upon different lifestyles that intersect at every street corner-between customers and merchants, or in other casual encounters-generating unexpected exchanges, conversations, and emotions. The atmosphere of the city emerges both from the possibility of such encounters and from their realization. The city is a place where such encounters can occur, and its atmosphere emerges from the fact of their occurrence. Conversely, however, the very interdependence of parts of the city defined as hostile to each other may engender fear, anticipation, and other emotions caused by the threat of violence and the permanent conflict and division. In other words, it is the fact that Palestinians and Israelis interact and move in the city despite the wall that both creates the city as "Jerusalem" and also lays the groundwork for fear. The military presence and erection of the security fence inside the borders of Jerusalem give to its metropolitan life a new significance but do not end that life altogether.

Paradoxically, it is because the foundations of exchange, of neighborhoods, or of existence itself are threatened that the texture of the urban exchanges appears, i.e., the texture of the city. These are the particularly intense urban exchanges of a divided and militarized city. Spatial confinement creates practical ordeals through which an individual measures himself in relation to his environment. It is in the most problematic of conditions that this research makes sense, when individuals affected and troubled by events (Boltanski 2009; Dewey 2005) work to resolve the enigma of their own lives.

To achieve this, it is useful as a sociologist to turn to ethnographic research that may give us insight beyond a first general impression of the constraints of the wall. Ethnography enables us to see the ways that actors use various principles and resources to resolve the problems of their everyday lives in the face of enclosure and thereby how they assert the plurality of their forms of existence and action. We see here that people are not only subject to the barrier and its enforced separation but that they also have critical and reflexive capacities. They work to continue their existence. Within the regime of enclosure, they use an eclecticism of relationships and actions to access primary goods: housing, labor, mobility, education, and domestic production. We can only touch on a 
few of the actions-some superficial, others more profound-through which the confined individual (in this case a Palestinian) reconsiders his or her universe and sometimes his or her relation to the Other (the Israeli).

\section{Excursus Outside the Boundaries: Workers, Residents and Merchants as "Transfugees"}

For the citizens of East Jerusalem, the political model of separation and security implies a new definition of territorial belonging, of exchange, and of mobility. The separation wall has been complete since 2009 and has become the residents' visual and existential horizon. It puts into place a new type of challenge that is no longer a test of force (by military control) but a challenge to reality-through administrative control and new mechanisms for exchange and circulation. The wall has become a frontier. Crossing through the wall is only possible at one of thirteen checkpoints that are regulated and controlled by the Israeli military administration, which also carries out exacting and regular patrols from the watch-stations situated along the wall. To enter Jerusalem, Palestinian residents or workers must have special work permits ${ }^{4}$ that are contingent on certain civic, familial, or security-based criteria and also on the economic needs of Israel (in the case of workers).

By describing a within and a without, the separation wall has redefined social relations, erased advantages and privileges, weakened the capacities of individuals to move about, and brought internal fractures to light. Since the completion of the security barrier, Jerusalem as a place of work has become inaccessible, despite the active trade and extensive job and knowledge networks that existed in the preceding period. The judicial and physical separation has considerably reduced the personal connections that once existed between Palestinians and Jews or among Palestinians from Jerusalem, while informal transactions have been curtailed. Despite this, maintaining exchanges with Israel or the Territories remains a priority for Palestinians. It is necessary to differentiate superficial engagements that are created for instrumental ends-the search for work or for business-and those that are longer lasting where the person's ontology, as well as the ontology of the group, is itself destabilized. In all cases, the interactions comprise practical, situated actions that allow actors to meet.

Restaurant owners and shopkeepers situated at the limit of the wall are an instance of those who must develop concrete transactions and strategies to continue their trade. An example would be the shopkeepers 
in the city of A-Ram, situated at the limit of the security barrier, near the main entry and exit checkpoint to East Jerusalem (Qalandiya). This checkpoint forms a true buffer zone with Israel and is particularly constraining for people entering the West Bank (where Israeli settlements are located) but also for the Palestinians of Jerusalem who continue to pursue activities or have family in Palestine. All crossings at this checkpoint-cars, trucks, pedestrians-are verified. ${ }^{5}$ Workers hailing from the Territories who are authorized to make the crossing into Jerusalem are particularly scrutinized. These workers are not able to use their personal vehicles and must be in possession of a work or residence permit. Despite the closed and rigid character of these security measures, many interactions take place around the checkpoint, creating a public spectacle where every act is visible to those taking part, including those of the Israeli military personnel charged with controlling the frontier. The area surrounding the checkpoint forms a microeconomic space with the presence of small shopkeepers offering their services: we find coffee and water from the nearby refugee camp al-Amari, restaurants, taxis. All are interested in maintaining their economic interests despite the rarefied nature of the exchanges between Jerusalem and the zones located on the other side of the security barrier, which itself has become an impassable frontier.

One example is striking: the ritual undertaken by certain restaurants to "deliver" to checkpoints in order to maintain their commercial activities. This concerns, for example, restaurant owners situated near the security barrier (A-Ram), who have created links to a Jewish or Arab clientele within Jerusalem who previously frequented these restaurants and have been deprived of this possibility by this newly constructed segment of the barrier. This is the case for Elias, a resident of Jerusalem who chose the site for his restaurant only several months before the erection of the barrier at A-Ram. His pizzeria, known for the quality of its products, is now hidden and inaccessible. Elias' movement has also been limited, and his restaurant lost many potential clients. Nevertheless, the young entrepreneur found a way to counteract this loss of business. Armed with a strong network of relations with Jewish and Christian Israelis and with Palestinian families from the Old City, he is able to deliver his pizzas to these privileged clients. Sensitive to Elias' economic situation, they make the journey specially to buy his products at the Qalandiya checkpoint. Pizza delivery, like a well-honed choreography, takes place in the presence of military personnel who closely watch the exchange.

The "delivery" of merchandise, of meals, is an urban experience that creates interactions within public space. The physical environment is mobilized, while communication between partners in the exchange, Israelis 
and Palestinians, takes place within neutral and interstitial spaces such as checkpoint parking areas (Qalandiya and Bethlehem). In the case of these "deliveries" - or of certain micro-commercial activities that take place along frontiers, in a space of surveillance-sovereign space relaxes or transforms into a space of civility based on the conversation and ordinary acts (oral exchanges, food exchanges). These types of exchanges, which continue despite the divide and the growing hostility between the two communities, make it possible to stabilize relations between actors.

Take, for example, the case of farmers of Bethlehem and Hebron, who arrive every morning at the gates of East Jerusalem to sell their products. Their portals to the outside world (Jerusalem and Israel) - the checkpoint crossings to Bethlehem-are only possible because of a chain of tolerance and the support of different partners. In certain cases, their excursions require the complicity of military personnel, because the farmers do not legally have access to Israeli territory or to Jerusalem. The officers close their eyes to foodstuffs transported in sacks, baskets and blouses, and give the farmers the right to enter the capital clandestinely. In turn, Palestinian boutique owners in Jerusalem agree to keep or stock the farmers' products. The farmers themselves, often elderly, spend the night in the back of the shops, in the doorways of shops, in residences in the Old City or in public spaces. ${ }^{6}$ Concern for the common decency of the Other has made it possible to establish this chain of acts that links individuals otherwise divided socially and geographically, differentiated one from another in terms of their status as citizens.

The consolidation of exchanges in the workplace is also striking. Lacking Jerusalem-resident status, ever more difficult to come by, or else without permits to work or freely circulate that require drastic measures to obtain, it is difficult for businesses and job-seekers to develop contacts. In part because of the increasingly complex nature of legal immigration procedures, maintaining access to work is almost impossible without the aid of formal or informal networks that assist with border crossings between Jerusalem and the West Bank. For a Palestinian to acquire a job, for example in Jerusalem or in Israel, requires that he or she go through an organized network - with companies based in Jerusalem or in Israel that have contacts with the military administration-to negotiate a permit or to sell products or services in Israel.

Permits are rare, depending entirely on a vertical organization between employees, employers, and the Israeli administration: a liberal state model where economic interests-and corruption-combine with military interests. Parallel to the official network of entrepreneurs, other types of practices are developing. They can be understood as a possible response to the coercion that is placed upon Palestinians wanting to 
work in Israel-despite the fact that Palestinian institutions symbolically forbid Palestinians from doing so in the name of the boycott and of the "White Intifada," the call for a sustained, nonviolent campaign of Palestinian resistance. Informal practices that deal with work and the crossing of the wall are indissociable from a horizontal chain of confidence between employees and employers or within a controlled community.

Then there is an entirely different clandestine organization that shuttles people through the wall with organized passage points or with ladders that make it possible to climb over. These activities imply complicit neighbors, people to organize shuttling back and forth-passers-and an entire way of thinking that leads to the creation of temporary neighborhood communities of passers (Druze, Arab Israelis), businesses, and neighbors. The interactions vary from a paid barrier crossing service to simply the aid of the neighbors-for example, watching for the arrival of the police. This leads to coordination between the various actors-that is to say, communication skills. Of course, these interactions are rarer than the everyday transactions described earlier, and they develop only in situations where the illicit crossings are a last resort. The relationship that links these individuals is built within space through connections and fleeting agreements.

"We just want to live," repeat day-workers, residents of A-Ram, Bir Nabala, or Bethlehem. Their voluntary actions take shape in a world of suffering. To stake one's life by crossing the security barrier means risking prison for a salary, putting one's family in peril with illegal actions, and risking the judgment of those close to you or of the community. The latter is especially problematic in the case of Palestinian workers in the Israeli settlements - a type of work strongly forbidden by the Palestinian authorities ${ }^{7}$ - and also in the case of intelligence cooperation with the military regarding counterfeit work certificates. Palestinians from Jerusalem or the Territories working intermittently on the construction or cleaning of the security barrier are also taking great risks.

These workers' excursions into an "enemy" world are, by all accounts, linked to the economic motivations of the two parties. Employers have access to labor that is flexible, easily managed, and readily available, and the employee sees the opportunity for Israeli work as a means to better his condition. These workers may also invoke a moral justification for this excursion and the "collaboration" it entails. For example, he may speak of his own victimhood and the instrumentalization of judicial and economic resources of the "Israeli enemy" as a political act of resistance. In most cases, the workers are blind to moral and political divergences, or to communitarian or cultural differences between them and their employers, instead revealing mutual understandings based on confidence 
and common interest. ${ }^{8}$ But the regime of forced connections with the Other through labor and business may also lead to a moral and social duplicity. The workers, moving between one world and another, modulate their rhetoric and appearance based on whether they are inside their communities, outside, or between several sets of juridical and political norms - for instance, situations in which they must recognize the State of Israel or not). The actors can also be destabilized in terms of their relation to their own community by entering into contacts with other norms during the period of transaction. They can also destabilize the grammar of their own community-by betraying their own patriotism.

If we take, for example, the case of Palestinian workers, Bedouins, workers in the formal and informal sector of the industrial complexes in Mishor Adumim and in the Jordan Valley, perceived indignity and humiliation often reappear in these workers' statements and are linked to their labor conditions (low salaries, no social rights, and no vacation days). And it is through these injustices that certain workers today get in touch with humanitarian organizations to defend their basic rights and to benefit from the same working conditions as Israelis. By turning to the courts and to workers' aid associations with their demands and with the discrimination they face, they implicitly recognize Israeli law and the presence of Israeli interlocutors, such as Israeli legal aid associations. Thus, contact with the adversary in the name of the defense of basic rights but also with a certain liberal individualism would suggest the renunciation of the principles of a Palestinian resistance that is founded on non-contact and the boycott of enemy interlocutors in the name of group solidarity. Encounters with outside partners (lawyers, NGOs, courts), the confidence these meetings create and the feeling of being defended, lead these workers to experience a certain distance from their own community. Their families, on the other hand, may feel embarrassed by these public efforts and the disobedience to their own group's rules that they imply.

\section{Situational Exchanges}

We could also cite a second case that speaks of a less superficial engagement with the renegotiation of collective norms through individual choice: Palestinians who settle in Jewish quarters called Israeli settlements because they are built outside of the frontier of 1967. These urban Jewish districts (like Pisgat Zeev) are populated with religious Jews (often Hasidim) or National Religious (Zionist) and were the first to be built outside of the Green Line. They are home to several hundred Pal- 
estinians. Thirteen hundred of the 42,000 residents of Pisgat Zeev are Arab. Very close to Pisgat Zeev, on French Hill, one person out of six is Arab out of a population of 7,000. Finally, in Neve Yaakov, there are six hundred Arabs out of 20,000. ${ }^{9}$

There are two motivations for this phenomenon. The first is what many perceive as the necessity of retaining their Jerusalem residence permit. In such cases, persons who were residents of Jerusalem before the erection of the wall have left what is now the Palestinian side to relocate to an area where they can retain their residency. ${ }^{10}$ The wave of returning Palestinians inside the limits of East Jerusalem has been an important factor in skyrocketing real estate prices. ${ }^{11}$ As a result, Palestinians concerned with conserving their rights sought out apartments in the first settlements in East Jerusalem such as Pisgat Zeev. This rental activity creates transactions with a network of real estate agents-Jewish-that are more or less discrete, and a redeployment of communitarian movements that are more or less accepted: Palestinians turn up in cafes and in malls located in Jewish neighborhoods and more or less also in public spaces. The recent public nature of identity has been the source of some incidents: verbal abuse and mutual violence in the shopping malls, protest posters fixed to synagogue walls, the intimidation of Jewish real estate agents selling land to Arabs. The press and activists for Israeli religious rights often speak out about a troubling menace: the turning back of Jewish repopulation through Arab settlement. "The Jews are leaving and the Arabs returning," announced a community Israeli newspaper, ${ }^{12}$ as if the latter were imitating the former through a reconquest of the space, ethnicity, and real estate of Jerusalem.

But another type of more individual mobility exists: Palestinians who already live within the perimeter of Jerusalem and make the choice to live in the Jewish districts at the entry of East Jerusalem. Here we find an example of pluralism that is expressed by the decision to maintain a social life outside of one's own community. Decisions to leave Arab neighborhoods to attempt to integrate into quarters such as Pisgat Zeev or Ramot become a choice that speaks to concerns for a way of life: a desire for social ascension that also makes it possible to benefit from the cultural, educational and health facilities of Israeli Jews, judged to be better that those in Arab neighborhoods. Such decisions to settle in Jewish districts are discrete and remain unpublicized among their community because they cannot be argued in terms of necessity. ${ }^{13}$ On the one hand, middle-class and professional Palestinians-for instance, officeworkers, professors, or doctors working in Israeli hospitals-make a pragmatic and subjective choice to settle within Jewish districts that may be seen as betrayal by their own family and community. On the other hand, 
the diversity within a Jewish neighborhood imposes rules of civility. We find ourselves here within the public rules of "civil inattention" (Goffman 1971) that define a mode of living together based on an indifference toward communitarianism and respect for private life. ${ }^{14}$

The last example comes from the Jerusalem tramway that was put into service in the spring of 2012. It crosses the city from northeast to southwest, through Israeli neighborhoods created in 1948 and into the city center. It runs parallel to the Old City, crossing Arab quarters, and ending in colonies that are at the frontier of 1967. The tramway project led to important ideological controversies: it was denounced as an instrument of Zionism, a consolidation of the annexation of Jerusalem, and as a political project destined to achieve the unification of Jerusalem by serving the residents of the settlements. Nevertheless, the project can be understood as a kind of laboratory for the study of the city as mosaic-the open city. We note the high participation of Arab citizens and the network's utilization by a mixed group of inhabitants: frequent tram users are Orthodox religious Jews as well as young and old Palestinians. Circulation is a moment of civility and diversity, a moment where a public space is created that breaks up communitarian divisions. Mobility is a place of contiguity and a personal or collective test where the voyagers have to show their ability to be face to face. ${ }^{15}$ Here we find again the notion of "civil inattention" and of reserve. The social order of the tramway functions through a minimum amount of tact and a visual courtesy that operate as a kind of poor interaction (Joseph 1997) or civil inattention. The oxymoron suggests that the importance of the superficial exchange is having a social function that guarantees civility. It requires participants in a situation that is public and delicate because of its intercommunal nature to not presume the Other has hostile intentions and to not manifest feelings of discomfort or shame. This visual courtesy also enables a superficial sociability to take shape. Within the tram, we speak several languages and we identify different ways of being-religious first of all, secular, Jewish, Arab, tourist, and foreigner-without a communitarian hierarchy, which is exactly the definition of a public space. This mode of transportation of course makes it possible to cross the city and also implies collective surveillance, vigilance, and a certain confidence between groups. Circulation is thus the means through which ephemeral ways of living together are understood. From this point of view, the tram is a success in that it does not lead to incidents of conflict or violence, as if it is able to engender that which diplomacy has itself been unable to create.

Such examples give us the contours of temporary communities of confidence-within economic activity, or public space-that are created in 
situations where people simply come together, without affirmations of belonging. All these situations require communication and informal exchange and show the potentiality of the city of Jerusalem itself, despite the political situation, to elucidate a theory of interdependence that is both political and sociological. From such cases, we open up several potential questions related to contiguity and hospitality in divided cities such as Jerusalem.

\section{For a Theory of Minimal Co-presence as Sociological and Political Frame}

Rebecca Bryant, in the introduction to this volume, makes a subtle distinction in approaches to coexistence. While the term "coexistence" is often used in general, historical, and even diplomatic terms, without practical considerations, she asks what coexistence means at the level of quotidian interactions. She suggests everyday diplomacy as a way to expand spaces, relations inside a constructive ambiguity, considering the potential self-transformation of identities and places. Bryant, in her introduction, speaks of the necessity of a constructive ambiguity of the boundaries of belonging as a language allowing the parties to overcome the issues about which they were at first irreconcilable.

In a previous chapter, Anita Bakshi discusses Simmel's notion of the stranger as descriptive of relations between Greek Cypriots and Turkish Cypriots in the Nicosia marketplace. These were the relations of shopkeepers with customers, of traders with clients, and of neighboring traders within the marketplace. In a city whose neighborhoods were mostly ethno-religiously divided, the marketplace became one of the few spaces where interactions occurred that are today remembered as "coexistence." Although those relations for the most part were not able to survive the fracturing of violence, they were the basic foundation for interaction outside one's group in the context of a relatively divided society.

In Jerusalem, institutions, habits, and the recurrence of geopolitical conflict have put into place a closed, east to west, functioning of neighborhoods that reflect the hardening of identities. The disordered, chaotic, hyper-dense, and walled-in space of East Jerusalem evokes a painful geopolitical history. Enclaves, the wall, and the refugee camps mark places of minority life excluded from municipal politics. They form what Oren Yiftachel calls "gray spaces":

The concept of "gray space" refers to developments, enclaves, populations and transactions positioned between the "lightness" of legality/ 
approval/safety and the "darkness" of eviction/destruction/death. Gray spaces are neither integrated nor eliminated, forming pseudo-permanent margins of today's urban regions, which exist partially outside the gaze of state authorities and city plans. (Yiftachel 2009: 243)

However, even within the confines of these gray spaces, and even in the context of growing hatred, it is difficult to overlook the physical and spatial interdependence that is the basis or has been the basis of relations.

We know that Jerusalem was always a cosmopolitan city, and that until recent wars its Arab and Jewish populations had spaces for interaction. In the early twentieth century, Jerusalem was home to cosmopolitan cafes, interactions between Arab and Jewish intellectuals and activists, and a certain atmosphere of bilingualism that characterizes the "spirit" of many cities. The sociologist Salim Tamari (2008) has shown that subsequent wars, nationalism, and sometimes the destruction of public spaces have removed this urbanity. But does this assessment privilege certain forms of sociality over others? Can or should the pluralist city exist in a context of conflict and tension?

Paradoxically, the material manifestation of the Israeli-Palestinian or Israeli-Arab conflict in the divided city of Jerusalem allows consideration of the positive aspects of coexistence. Even inside the divided city, citizens are not constrained to a trajectory on the basis of communal affinity. Citizens weave a path, encounter obstacles and opportunities. They travel in "foreign" areas, and necessarily encounter Others. Being Jewish or Arab-not to mention a member of the mizrahim (Eastern) or Ethiopian minorities, for example-today refers to a particular condition, that of identification with a neighborhood, a mosque, a synagogue, a part of the occupied city. Yet the real city does not coincide with the illusion of harmonious communities locked inside their own territories. Instead, the character of the city is also one of dissonance-what Bryant in the introduction, citing Laura Ring, refers to as "bearing tension"where laboring to surmount obstacles and overcome potential conflict is also part of what it means to live together in the city.

This "moral crossing" or co-presence, I claim, is an organizing principle of civil life that can be not only understood as an urban phenomenon but also deployed as a philosophical principle. I consider co-presence as a sociological and political method that exceeds the metaphor of a "mosaic" of communities and their territories, and one that may help us think about the sources for a regeneration of urban dynamics. What, then, are the features of a notion of co-presence? The first is understanding the city as a milieu for acquaintance where the stranger might be seen less as a foreigner-a representative or custodian of a community-and 
more as a smuggler. The stranger as smuggler crosses spatial and moral regions using bilingualism, resourcefulness, and skills of cultural translation. As a type of "everyday diplomacy," it requires self-transformation, but it does not have the connotation of the diplomat as emissary.

A second element is the porosity of the city, which encourages all sorts of interaction, including the right to intrusion and mobility. The latter includes intercultural circulation, guaranteeing mixing, with the possibility of leaving the community to which one belongs (Park 1967). Co-presence occurs, for instance, through the circulation of people, and the choice to live in different areas. The spatial entanglement, the dependence of Palestinians on the Israeli job market, and the need for economic trade between the two parts of the city or of the Territories make relations necessary. And this physical contiguity in Jerusalem has, in the very near past, resulted in an ensemble of relations.

The city of Jerusalem could be viewed as one that encourages interaction-in the image of the journey of the tramway, a crossing of multiple worlds, near and far, those by which the individual reconsiders his or her universe of belonging. It is the replacement of communitarian links by social relations that create a form of positive urban interaction. Co-presence, then, is possible within the open city, a form of sociality not structurally determined, but rather dependent upon circulation, chance meetings, and superficial exchanges. Only social interaction (what Bryant in this volume calls everyday diplomacy) can break the rigidity of closed groups and of ethnic circles bound by familiarity, making it possible to decrease hostilities.

In other words, following the sociologists of the Chicago School, we might say that the city needs more sociality and less society: that is to say, less collective treatment of social realities by institutions. The idea of co-presence puts emphasis on living together as a practice rather than as an ideal. Rather than ideals or ideologies, co-presence is a matter of tact. It assumes that citizens in the public space present themselves with distance and reserve, as suggested in the notion of civil inattention. In Jerusalem, tact may be seen in the case of tram transportation that crosses various districts of the Palestinian neighborhoods, caught between the Jewish settlements in East Jerusalem. Mobility can be seen as a test of citizens' capacities to interact in public, to demonstrate some communicative competences. ${ }^{16}$

A third, normative element of co-presence is pluralism, understood here not as a juridical frame but as pragmatic governance. Pluralism in this sense begins with the encouragement of mobility and a politics of contact. The capacity to visit, as both a moral and social virtue, assures the possibility of meetings between individuals. This kind of co-presence, 
still existing, does not erase frontiers, but it marks forms and spaces of contiguities. They must be understood as moments of relational contiguity and of the presence between people, beyond the threshold of rupture. This is the pluralism of hospitality, of being open to the other while also recognizing scales of sovereignty (see Bryant this volume; also Joseph 1997). ${ }^{17}$

Sociologically, such practical efforts already exist in Jerusalem even if they are rare. They appear in the social mixity of adjacent neighborsfor instance, in Pisgat Zeev-and in associations made possible by property and social diversity. Politically, in the absence of a common governance in Jerusalem - the PLO and the Palestinian political parties all refuse any kind of representation in local political bodies-some associations (Jews and Arabs) create common cause through common associations. ${ }^{18}$ In East Jerusalem (Beit Hanina), shopkeepers, residents, and property-owners, already engaged in the maintenance of exchanges, progressively make up a shared community. Such practices in turn create a habitus (Bourdieu 1980) that may be mobilized for other politics. Such uncommon "communities of confidence" are rare and discrete but demonstrate the potential for an idea of coexistence that includes conflict and tension within sociality and that allows us to think differently about forms of urban governance (Lofland 1998).

\section{Conclusion}

Individual and ethnographic portraits have shown us forms of interaction even within the most extreme conditions of division and polarization. Viewed not from the perspective of an ideal model of coexistence but rather from its actual practice, we see that small acts of respect for the Other-the exercise or not of domination, of courtesy, of civilitymay be able to construct a livable space, creating a place for people, while at the same time helping to build a shared life. This is a minimalist portrait of what Bryant refers to as the "labor of peace," depending not on the active maintenance of neighborly relations but instead on ordinary civility. It is this form of "peace building" - the constraints of ordinary civility-that I claim are central in the context of hostility where cultural and communitarian influences are strong.

The Palestinian philosopher Sari Nusseibeh ${ }^{19}$ reminds us that the future of Jerusalem, and more broadly speaking the treatment of the Israeli-Palestinian conflict, depends on "new ideas" (Nusseibeh 2011). Here I have addressed not the practice of coexistence per se, but rather its necessity and pragmatics in a non-ideal world (Anderson 2010). I also 


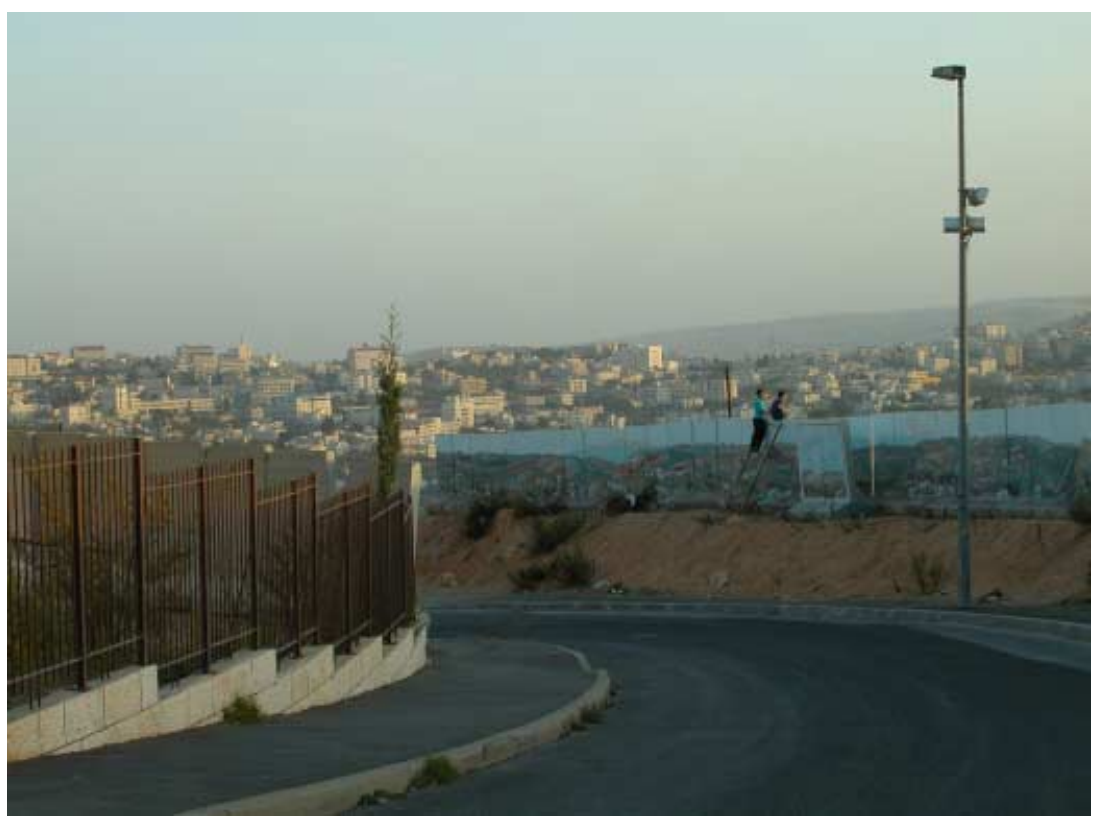

Figure 9.2. East Jerusalem (photo by Sylvaine Bulle).

suggest, however, that such a pragmatic approach to living together may form the basis for a politics beyond the communitarian, based on socioeconomic rights and an equality of spaces. This vision of justice is based not on control of institutions but on spatial contiguity and social respect on the neighborhood scale. From a sociological perspective, it is not improbable that ordinary politics may make it possible to achieve a more equitable city. It requires that violence disappear so that democracy can take its place.

Sylvaine Bulle is a sociologist, assistant professor and researcher at CRESPPA (University of Paris 8) who studies the Israeli and Palestinian post-national societies, with a special focus on social justice and the sociology of conflict. Her recent research concerns intercommunal relations, state transformation, and social mobilization. She has published widely on questions of justice, critical theory, and the political anthropology of war, and is now working on the new waves of contestation in Israel as well as in the Palestinian Territories. Her latest publication in English is, "Toward Some Social Ecology: Policies of Domestication in a Confined Territory (East-Jerusalem)," in Between the Lines: Social Ecologies in a Liminal Landscape, ed. A. Grichting and M. Zebich-Knos (Chicago: University of Chicago Press, forthcoming). 


\section{Notes}

1. According to Schmitt, the nomos is a kind of juridical order based on a territorial delimitation of the nation.

2. The demographic policy of Israel aims first of all to limit the presence and the social cost of Palestinians in East Jerusalem. The capital has 765,000 people, 495,000 of whom are Jewish (65 percent), half living in the eastern section, and 270,000 Arabs (35 percent), almost entirely Palestinians in East Jerusalem. Furthermore, 80,000 Palestinians currently have permanent resident status in Jerusalem but do not live within the municipal limits of the capital. The Israeli administration is currently controlling the situation by ending residence status for married persons whose partners come from the Territories but live abroad.

3. See for instance Graham (2010); Weizman (2003); and Azoulay and Ophir (2005).

4. Based on the needs of certain sectors open to Palestinians, such as construction (approximately 60,000 authorized and legal workers) and according to the demographic equilibrium objective in Jerusalem between the Jewish populations (70 percent) and Arabs (30 percent) for requests for residence in Jerusalem.

5. Every Palestinian crossing into one of the Palestinian sub-zones is henceforth subject to computer and biometric verification based on a personal dossier that includes information about a person's geographic and family origins and their employer. The management of these checkpoints is under the control of the Israeli Defense Forces and in certain cases is subcontracted to private security firms with contracts with the army. Palestinians hailing from the Territories are not authorized to enter Jerusalem except under exceptional circumstances (sickness or a special permit). Marriages and family reunification between citizens of the Territories and Jerusalem are extremely rare and must fall under specific criteria (birth in Jerusalem, security criteria, children born in Jerusalem).

6. For example, the Damascus Gate, the northwestern gate of the Old City. Analysis is based on surveys in Jerusalem and the West Bank (2009-12).

7. Approximately 25,000 Palestinian workers are employed in the Jewish settlements (Israeli statistic 2011). Israeli settlements are military or civilian implantations built on lands occupied by Israel during and after the 1967 Six-Day War. Such settlements currently exist in the West Bank, East Jerusalem, and in the Golan Heights. In the 121 officially recognized settlements in the West Bank live 300,000 Jews; over 300,000 Israelis live in settlements in East Jerusalem. They have their own jurisdictions, law, and regulations due to their extra-territorial status.

8. On this aspect see Hirschman's essay (1970) on the moral economy at the age of capitalism.

9. According to the press.

10. The Palestinians of East Jerusalem, born and residing within the city perimeter benefit from resident status (without citizenship and therefore without 
a passport). They have economic, health and social rights, access to public institutions (hospitals, doctors, social aid), and pay city taxes.

11. Historically, only a few Palestinians inhabitants of Jerusalem live in the western or central areas (except the historical quarters of Beit Safafa, Ein Karem, and the old cities).

12. Matzav.com (The Online Voice of the Torah Jewry), 2/9/2009. See http:// www.thesanhedrin.org/en/index.php/Psak_5769_Av_23.

13. This also concerns the young Palestinians who choose to study, and sometimes live, at the Hebrew University located on Mt. Scopus, rather than in a Palestinian university.

14. For Goffman, the notion of civil inattention is an attention not focused on the Other. It consists of showing to the Other that we have understood and are attentive to his or her presence, but without taking notice of the verbal, oral, or gestural habits of the Other, thus without intruding into the life of the Other.

15. Elaborated by Erving Goffman (1971). The face to face is not only a way we define and interpret for ourselves a situation but also the way we engage ourselves in a course of action.

16. We can refer here to a recent experience in the tram, in which sixty young Israelis planned a demonstration in which they would speak Arabic while using public transportation in order to encourage contact.

17. For a philosophical and closed approach, see Derrida (1997).

18. For example, there is the case of the association that was against the demolition of the ancient village of Lifta situated at the entrance to West Jerusalem. Composed of activists as well as Jewish and Arab residents, the association demanded that the village be listed as a world heritage site in the name of environmental preservation.

19. Sari Nusseibeh is a Palestinian philosopher and an influential leader who is based in East Jerusalem.

\section{References}

Agamben, Georgio. 2003. Homo Sacer. II, 1, État d'exception. Paris: Seuil.

Anderson, Elizabeth. 2010. The Imperative of Integration. Princeton: Princeton University Press.

Azoulay, Ariella, and Ophir Adir. 2005. “The Monster's Tail: The Wall and the Logic of the Occupation." In Against the Wall, ed. M. Sorkin, p. 95-118. New York: The New Press.

Boltanski, Luc. 2009. De la critique: Précis de sociologie de l'émancipation. Paris: Gallimard.

Bourdieu, Pierre. 1980. Le sens pratique. Paris: Editions de Minuit.

Brown, Wendy. 2010. Walled States, Waning Sovereignty. New York: Zones Books. Cheshin, Amir, Bill Hutman, and Avi Melamed. 2001. Separate and Unequal:

The Inside Story of Israeli Rule in East Jerusalem. Cambridge: Harvard University Press. 
Derrida, Jacques. 1997. De l'hospitalité. Paris: Calmann-Levy.

Descola, Philippe. 2005. Par delà nature et culture. Paris: Gallimard.

Dewey, John. 2005. Art as Experience. New York: Berkley Publishing (1st ed. 1934).

- 2012. The Public and Its Problems: An Essay in Political Inquiry. University Park, PA: Pennsylvania State Press (1st ed. 1924).

Dumper, Michael. 1996. The Politics of Jerusalem Since 1967. New York: Columbia University Press.

- 2014. Jerusalem Unbound: Geography, History, and the Future of the Holy City. New York: Columbia University Press.

Fraser, Nancy. 2008. Scales of Justice: Reimagining Political Space in a Globalizing World. New York: Columbia University Press.

Goffman, Erving. 1971. Relations in Public: Microstudies of the Public Order. New York: Basic Books.

Grafmeyer, Yves, and Joseph Isaac. 1984. L'Ecole de Chicago: Naissance de l'écologie urbaine. Paris: Aubier.

Graham, Stephen. 2010. Under Siege: The New Military Urbanism. London: Verso Publishers.

Harvey, David. 2009. Social Justice and the City. Athens, GA: University of Georgia Press (1st ed. 1973).

Hirschmann, Albert. 1970. Exit, Voice, and Loyalty: Responses to Decline in Firms, Organizations, and States. Cambridge, MA: Harvard University Press.

Honneth, Axel. 1996. The Struggle for Recognition: The Moral Grammar of Social Conflicts. Cambridge, MA: MIT Press.

Ingold, Tim. 2000. The Perception of the Environment: Essays on Livelihood, Dwelling and Skill. London: Routledge.

Joseph, Isaac. 1997. "Prises, réserves, épreuves." Communications 65, p. 131142.

Kimlycka, Will. 2001. Politics in the Vernacular: Nationalism, Multiculturalism, Citizenship. Oxford: Oxford University Press.

Lofland, Lyn. 1998. Public Realm: Exploring the City's Quintessential Social Territory. New York: Aldine Transaction.

Marcuse, Peter, and Ronald Van Kempen. 2002. Of States and Cities: The Partitioning of Urban Space. Oxford: Oxford Geographical and Environmental Studies.

Nussbaum, Martha. 2006. Frontiers of Justice. Cambridge, MA: Harvard University Press.

Nusseibeh, Sari. 2011. What is a Palestinian State Worth? Cambridge, MA: Harvard University Press.

Park, Robert, and Burgess Ernest. 1987. The City: Suggestions for Investigations of Human Behavior of the Urban Environment. Oakland, CA: University of Chicago Press.

__ 1984. "La ville comme laboratoire social." In L'Ecole de Chicago: Naissance de l'écologie urbaine, ed. Y. Grafmeyer and I. Joseph, p. 167-179. Paris: Aubier. 
Pettit, Philip. 2001. A Theory of Freedom: From the Psychology to the Politics of Agency. Oxford: Oxford University Press.

Rawls, John. 1999. A Theory of Justice. Cambridge, MA: Belknap Press of Harvard University Press (1st ed. 1971).

Rancière, Jacques. 1995. La Mésentente. Paris: Galilée.

Schmitt, Carl. 2003. The Nomos of the Earth in the International Law of the Jus Publicum Europaeum. New York: Telos Press Publishing (1st ed. 1951).

Sen, Amartya. 2010. The Idea of Justice. London: Penguin Books.

Simmel, Georg. 1903. "The Sociology of Conflict: I." American Journal of Sociology 9: 490-525.

- 1971. "The Metropolis and Mental Life." In On Individuality and Social Forms: Selected Writings, ed. Donald N. Levine, 324-39. Chicago: University of Chicago Press.

- 1999. Sociologie: Études sur les formes de la socialization. Paris: Puf.

—. 1984. "Digressions sur l'étranger." In L'Ecole de Chicago: Naissance de l'écologie urbaine, ed. Y. Grafmeyer and I. Joseph, p. 53-60. Paris: Aubier.

Tamir, Yael. 1993. Liberal Nationalism. Princeton, NJ: Princeton University Press.

Tamari, Salim. 2008. Mountain Against the Sea: Essays on Palestinian Society and Culture. Oakland: University of California Press

Tilly, Charles. 1998. Durable Inequality. Berkeley: University of California Press.

Weizman, Eyal. 2003. A Civilian Occupation. London: Verso Books.

Wirth, Louis. "Le phénomène urbain comme mode de vie." In L'Ecole de Chicago: Naissance de lécologie urbaine, ed. Y. Grafmeyer and I. Joseph, p. 255-282. Paris: Aubier.

Yacobi, Haim. 2009. The Jewish-Arab City: Spatio-Politics in a Mixed Community. London: Routledge.

Yiftachel, Oren. 2009. "Critical Theory and 'Gray Space': Mobilization of the Colonized." Cities 13(2-3): 240-256.

Young, Iris Marion. 2007. Global Challenges: War, Self-Determination, and Responsibility for Justice. Cambridge: Polity Press.

- 2010. Responsibility for Justice. Oxford: Oxford University Press.

Walzer, Michael. 1983. Spheres of Justice. New York: Basic Books. 
\%. Chapter $10 \cdot 6$

\title{
Grounds for Sharing- Occasions for Conflict
}

\author{
An Inquiry into the Social Foundations \\ of Cohabitation and Antagonism
}

GLENN BOWMAN

\begin{abstract}
A lthough the title of this collective project refers to "shared spaces," we are for the most part discussing places rather than spaces when we talk of the social aspects of cohabitation and/or antagonism. Places in this context are lived-in spaces or, in more academic terms, sites of inhabitance, while space denotes an area, of general or unlimited extent, indifferently providing the physical setting for such places; hence the Oxford English Dictionary notes that "place" is "a space that can be occupied ... a particular spot or area inhabited or frequented by people; a city, a town, a village." 1 Spaces are far more easily "shared" than places, if sharing is the correct term to use when referring to coexisting in contiguous space. When suitably organized, entities can move past and around each other in space without effecting significant contact. Movement in shared places, however, entails negotiation, commensality, and at times conflict insofar as persons occupying place not only coexist with each other but are very much aware of the fact of that coexistence. In Michael Sorkin's fascinating discussion of "traffic" in Giving Ground: The Politics of Propinquity we see a modernist mode of organization that channels persons and vehicles into nonintersecting pathways in order to give priority to unimpeded flow at the expense of relations between entities moving across the same terrain. Counterposed to this Sorkin shows us a more traditional setting in which flow is impeded by repeated intersection and the necessary and mutually aware sharing of place:
\end{abstract}

Modern city planning is structured around an armature of ... conflict avoidance. Elevated highways, pedestrian skyways, subway systems 
and other movement technologies clarify relations between classes of vehicles for the sake of efficient flow.... The result is a city altogether different from the older Indian cities with their indigenous styles of motion.... Typically Indian traffic is completely mixed up, a slow-moving mass of cows and pedicabs, motor-rickshaws, trucks and buses, camels and people on foot, the antithesis of "efficient" separation. Motion through this sluggish maelstrom does not proceed so much by absolute right as through a continuing process of local negotiation for the right of passage. (Sorkin 1999: 2)

In the latter case we are shown not only a space occupied by persons and entities but a place in which those inhabiting the terrain are linked together by what he terms "a primal rite of giving ground ... the deference to one's neighbour that urban existence daily demands" (Ibid.). Here, rather than a skein of distinct and mutually disengaged pathways encompassed within a common space we see a place inhabited by a diversity of persons and objects, shared through processes of mutual recognition and accommodation.

I would like to look further at this issue of "giving ground" in the context of shared holy places in the post-Ottoman Mediterranean so as to evaluate how such places are shared, what sorts of situations support that sharing and what sorts of events or developments disrupt it. Sylvaine Bulle's chapter, in this volume, investigates neighborhood and the way that within a neighborhood a multitude of different groups of people are tied together into a community by networks that variously engage them as individuals and groups. Foregrounded by her examination of how shared practices of being in a neighborhood enable both the recognition of the difference of others and the framing of that difference as something beneficial rather than problematic is the issue of whether we can see local communities, and the set of relations that constitute them, as forms of what Bourdieu called habitus. ${ }^{2}$ Bourdieu, in the rather dense terminology of his Logic of Practice, writes that

[t] he conditionings associated with a particular class of conditions of existence produce habitus, systems of durable, transposable dispositions, structured structures predisposed to function as structuring structures, that is, as principles which generate and organize practices and representations that can be objectively adapted to their outcomes without presupposing a conscious aiming at ends or an express mastery of the operations necessary to attain them. (Bourdieu 1990 [orig. 1980]: 53)

Practices of interaction and negotiation of place experienced through living in a community imprint themselves in individuals as preconscious 
dispositions to act, and interpret, in the future in accordance with those earlier experiences. A person's dispositions are neither habits nor consciously applied rules but tacit knowledge, often embodied, learned through the "prestigious imitation ... [of] actions which have succeeded and which he has seen successfully performed by people in whom he has confidence and who have authority over him" (Mauss 1979 [orig. 1935]: 101). As Mauss, and Bourdieu after him, make clear, it is this process of internalizing social practices (actions, interpretations, self-presentations) that imposes the social on the individual and that, in effect, maps the neighborhood-and its modes of incorporating and negotiating with internal difference-onto the selves who traverse it. "Giving ground," recognizing the right of the Other to be in the same place as oneself as well as committing to the rites of negotiating her presence, is a core element of the habitus of neighborhood.

Two ethnographic studies, one on South India and one on the North, exemplify the ways neighborhoods constituted by nominally distinct religious communities (communities that are elsewhere mutually antagonistic) are able to share place peacefully. The first text, Jackie Assayag's At the Confluence of Two Rivers-Muslims and Hindus in South India (2004), discusses what might be called a situational syncretism whereby Muslims and Hindus are able to celebrate at each others' religious festivals because, in the course of the communities living together for nearly a millennium, cultural elements that might have in the past been the exclusive properties of distinct communities have become part of an annual cycle of neighborhood practices and thus, in effect, common property:

The religion of Mohammed insinuated itself very gradually in a Hindu environment already segmented by numerous castes, sects and local traditions. This mixture of discreet elements gave rise to many subtle and complex forms of acculturation caused by alteration, addition, superimposition and innovation, which vary from region to region. So by absorbing elements that were no longer either strictly Hindu or Muslim, but may have been the result of an earlier assimilation, these cultural forms allowed movement between systems of action and representation that seemed to be mutually exclusive. (Assayag 2004: 41)

Anna Bigelow's Sharing the Sacred: Practicing Pluralism in Muslim North India (Bigelow 2010; see also Bowman 2013) treats a seemingly more conscious process of intercommunal cohabitation in the town of Malerkotla, located in the Punjab, a far more conflicted region than Assayag's Karnataka. Bigelow notes that the town's cultivated tolerance 
might be seen as a response to Malerkotlan residents' horror of the sectarian cleansing that afflicted the Punjab during Partition (as well as of the violence of subsequent sectarian riots that have taken place in the region over the past few decades) leading to their recognition that "all religious groups are in some regard vulnerable ... [making them] cognizant that their wellbeing depends on their positive relations with others" (Bigelow 2010: 10). She, however, demonstrates fulsomely that overt intercommunalism is very much grounded on the town's "practice of everyday pluralism" (Ibid.: 217) and is a projection of "the vibrant community life in the streets and homes and shrines of a locale" (Ibid.: 223). In each case the "cultural property" of one sectarian community is seen by members of adjacent communities as theirs as well, not because they wish to appropriate it but because, via a process of living with the "owners" of the property and engaging with them in their quotidian lives, that property and the practices surrounding it have come to be seen as common. Whereas in some cases, such as those described by Assayag, sharing is for the most part unconscious because the traces of the ownership of significant elements of cultural property have been effaced by time, in others, as in Bigelow's Malerkotla, practices of mutual engagement in religious festivals and shrine worship are conscious moves to affirm community solidarities across sectarian borders. In both instances, however, sharing in religious celebrations and festivities is an extension of the habitus of a shared communal life. ${ }^{3}$

This is not, of course, to say that an identical "script" of community response is instilled in all the community's members by their participation in a neighborhood. While the term "disposition" suggests a tendency to interpret situations and act in response to them in certain ways familiar from past engagements with similar events, Bourdieu's work, like Mauss' before it, makes clear that there is "play" in the system of application allowing for accommodating specificities of context, of individuality, and of intention. A disposition is a proclivity rather than an imperative. Part of what accounts for the lability of persons' responses in communities in general and mixed communities in particular is the multitude of identities at play in any individual's experience of everyday life. The concept of "situational identities" ${ }^{4}$ enables us to recognize a multitude of identity contexts existing in even the least complex of societies, and when a community creates complexity to the extent of encompassing multiple ethnic and/or religious identities, the opportunities for a proliferation of identity strategies expands commensurately. At different moments of interaction within the community, different dispositions will be called to the fore. Thus in one instance you might be working with someone as a coworker or in an employee-employer relation whereas in another, 
sometimes even contiguous with the first, you might be called on to represent a family or a religious denomination. Each of these situations will call on distinct dispositions and may in fact call for enunciating those dispositions in ways that improvise on previous enactments. What is important to stress is that none of these enacted identities are primary other than in situations - some of which will be elaborated below-in which the primacy of one of those identities is staged as more important than, and either subsuming or obviating, others. Recognition of the situatedness of identity articulations allows us to understand the ways numerous linkages can be made between diverse persons within a community, but also to see that certain events or developments might render previously amenable identities incommensurate and thus conflictual.

Nonetheless investigation of the character of neighborhood bonds resonates with Bigelow's investigation of Malerkotla's "daily work of community maintenance" (2010: 122) and indicates that in most instances communities will seek to perpetuate communal cohesion. The concept of habitus makes clear that the degree to which people are who they are is a consequence of the appropriateness of their learned dispositions to settings the same as, or not unlike, those in which they imbued those dispositions. Radical reworkings of those settings-either through intercommunal conflict and separation or through migration or exile-threaten selfhood. There are, of course, circumstances that bring about the fragmentation of communities, but these often come about through external influences that, through direct action or the indirect impact of rumors or propaganda, create distrust and antagonism between elements of the community (compare Tone Bringa's film We Are All Neighbours [Bringa 1993]). Left to its own devices a community will not only celebrate its social arrangement as natural and heimlich (homelike) but may, as in the instances described by Marcel Mauss in his study of magic, imagine the domain of its everyday life as knitted together by a skein of connections defying scientific conceptions of cause and effect and allowing efficacy at a distance through the manipulation of objects or settings associated via contiguity, similarity, or opposition (see Mauss 1972 [orig. 1950]). Here persons, powers, and things associated in everyday experience are seen as connected even when literally apart. For Mauss magic works by laying over the place of the everyday a distorting mirror that not only draws together diffuse elements but also allows power to operate across its surfaces. "In society there is an inexhaustible source of diffuse magic.... Everything happens as though society, from a distance, formed a kind of huge magical conclave around [the magician]" (Ibid.: 138). For Mauss, rites can bring about "direct, automatic efficacy, without the presence of differentiated spiritual intermediaries" 
(Ibid.: 136) so that, in the case of Dayak women engaged in war dances to support their men, who have gone off to battle,

time and space no longer exist; they are on the field of battle.... Their sensibilities are overwhelmed by the awareness of their existence as a group of women and the social role they are playing in relation to the warriors, an awareness which is translated into sentiments about their own power and the relation of this power with that of their menfolk. (Ibid.)

\section{Muslims and Christians in the Monastery of Sveti Bogoroditsa Prechista}

I mention this embodied sense of a habitus accessible through magic and ritual not so much to explain the mechanisms of how shrine practices can effect cures or the redirection of fortune but to suggest that the powers people imagine as working in and on their world are social powers, imagined in the image of their own experience of the world. Let me expand on this using an ethnographic encounter I had in Kicevo, Macedonia, in April 2006. I had been researching, with the help of Elizabeta Koneska of the National Museum of Macedonia, Muslim and Orthodox Christian uses of Sveti Bogoroditsa Prechista (the church of the Holy Mother of God Most Innocent) outside of Kicevo, itself a mixed Muslim and Christian town. In the course of examining the context of shared shrine practices, we interviewed the imam of the local Sunni mosque. $\mathrm{He}$, trained in the renowned Faculty of Islamic Studies in Sarajevo, responded to our queries about Muslims attending the nearby Sveti Bogoroditsa monastery by asserting strongly that he had never gone there and never would. He nonetheless went on to explain that he would advise members of his congregation to go to the monastery for help with particular problems because "the world of demons, like our world, is made up of Christians and Muslims. When someone is afflicted by a Muslim demon I can deal with the problem, but when someone is troubled by a Christian demon there is nothing I can do, so I send them to the church" (interview Kicevo, 30 April 2006).

What is of interest here, besides the concept of a mirror world of demons that replicates the demography of the lived world, is that-in this local context-the imam seems to see no incommensurability between this vision of the interaction of the demonic and the human worlds and that of a more Orthodox Sunni theology with its considerably more strict definition of domains, borders, and pollutions. However, as I will 
show later, when the world of religious orthodoxy impinges upon local practices it disrupts this inter-communalism, asserting property and propriety issues at the expense of sharing. Here, however, relations between the human and the demonic world are analogous to those occurring in the quotidian world of social interaction, and rites and obeisances made in the human world engage an economy or reciprocity with the demonic. Just as the demonic world mirrors the intermixing of Muslim and Christian while maintaining the difference between the two, so too do movements within the ritual space of the church maintain that differentiation, even as Muslims "tap into" Christian rituals to ward off Christian demons.

Sharing the space of the Sveti Bogoroditsa monastery's chapel does not entail a syncretic blending of identities, just as interacting on the streets and in the markets of Kicevo and its satellite villages does not effect an effacement of sectarian identities (compare Lockwood 1975: especially 195-211). Muslims within the walls of the church seem, on initial observation, to go through the same procedures of reverencing the saints and the sites of power as do the Christians: they circulate through the church, they light candles in front of the icons (particularly those of the iconostasis before which they lay gifts of clothing, towels, and sometimes money), they proceed to the rear left of the church where, like the Christians, they pass a string of cross-inscribed beads over their bodies three times before crawling three times through a passageway beneath a pair of healing icons toward a well from which, in leaving, they take water to splash on their faces and carry home in bottles for healing (see Bowman 2010: 206-9, for a more detailed description). Closer observation reveals that this apparent mimicry is subtly but significantly differentiated. Muslims, holding back from Christian groups, introduce small but important differences of deportment. They do not cross themselves, they bow their heads to but do not kiss the icons, and in praying they silently mouth Muslim prayers while holding their hands close to their chests in front of them with their palms up. Muslims here "work" an environment they know through the social world they share with their Christian neighbors and in so doing both engage in ritual acts that they have learned are efficacious from their neighbors (and their imam) and render appropriate obeisance to the powers resident in the place (the Virgin Mary, the saints, the Mother Superior, and the nuns). At the same time they refuse to violate their own identities by sacrilegiously adopting the signifiers of Christians as though they were their own. Here, in a religious setting we have an interaction analogous to what Sorkin describes in the dense streets of Indian cities-"the continuing process of local negotiation for the right of passage" (Sorkin 1999: 2). 


\section{Property and Propriety in Jerusalem's Church of the Holy Sepulchre}

The "sharing" described above-a sharing extending into religious places the same modes of intercommunal mixing one sees in the everyday interactions of neighbors in the streets and workplaces of the regiondiffers substantially from the types of interactions one sees between strangers in sites they commonly revere, but not "in common." I will try to resolve that seeming contradiction between "commonly revering" but not "in common" through the use of Slavoj Žižek's rendering of Saul Kripke's concept of the "rigid designator" (Kripke 1980). Žižek contends that the name for a phenomenon - the rigid designator-constitutes the ideological experience of the thing rather than the thing itself. Thus it is

the word which, as a word, on the level of the signifier itself, unifies a given field, constitutes its identity. It is, so to speak, the word to which "things" themselves refer to recognize themselves in their unity.... It is not the real object which guarantees as the point of reference the unity and identity of a certain ideological experience-on the contrary it is the reference to a "pure" signifier which gives unity and identity to our experience of historical reality itself. (Žižek 1989: 95-96 and 97; see also Vološinov 1973 [orig. 1929]: 79-80)

Generally, in a world of shared experience, "rigid designators" suffice to indicate objects and experiences common to those sharing that world, subsuming idiosyncrasies of personal experience or contextual application. However where quotidian experience is not shared, identical signifiers may conjure up very different signifieds for the communities using them, and the differences may in fact prove to be incommensurabilities. In earlier examinations of the politics of Palestinian identity before and after Oslo (Bowman 1988, 1994) I wrote of the different ways the name "Palestine" signified both a future homeland and a reunified people to communities in different locales of exile, both outside and inside the borders of historic Palestine. So long as those populations remained isolated from each other those disparities of understanding remained relatively unproblematic, but once Oslo effected a regathering of the Palestinians from the various sites of their dispersion serious conflicts erupted between groups over what Palestine should be, what Palestinians should be like, and who in fact was even truly Palestinian.

Something very similar happens at holy places with constituencies that gather from dispersed locales. Rather than neighbors sharing a sacred place we talk here of strangers coming together in the same space. 
The Holy Sepulchre in Jerusalem, known to Orthodox Christians as the Anastasis, lies at the center of an extended web of narratives dealing with the death and resurrection of Jesus. ${ }^{5}$ When I carried out field research on Jerusalem pilgrimage in the early 1980s, the Holy Sepulchre, like other sites throughout the "holy city" of Jerusalem, was visited by pilgrims from twenty-seven distinct Christian denominations (these, for the most part, are further divided into distinct national and linguistic communities) as well as by a multitude of tourists, many from Christian backgrounds but also many non-Christians. Five sects had places within the church-the Greek Orthodox, Catholics, and Armenians occupying the most territory, with the Coptic and Syrian Orthodox holding tiny chapels-while a sixth, the Ethiopians, held two external chapels and a rooftop. Despite that sectarian topography the church was swept daily with crowds of pilgrims and tourists flowing indiscriminately through the corridors and chapels. ${ }^{6}$ Such heterodoxy within a limited space could give rise to "traffic problems" (pushing, expressions of hostility, and occasionally fights, usually between individuals not travelling in organized groups), but for the most part conflicts were avoided by what appeared to be spontaneous traffic management. This took place not through "local negotiation" but because groups moving through the church effectively "enclaved" themselves into mobile units flowing past and alongside each other without either engagement or significant recognition (see Bowman 2011: 376-77). These groups, often made up of people coming from the same locale or brought together prior to the visit by an institution or a leader, constituted "in-groups" able not only to insulate themselves from others but also, under the authority of spiritual or secular guides associated with the respective groups, to ensure that their perceptions of the sites and events they encountered confirmed and built upon their expectations. Such a mode of engaging with holy sites ${ }^{7}$ protected the integrity of the connection between rigid designators and the experiences they signed while preventing the cognitive dissonance of other's readings of those shared designators from disrupting that alignment. While individuals within these groups shared with each other an experience of place, they simultaneously related to members of other groups like bodies in space, moving past and around them without effecting significant contact. Thus while this site might nominally be termed a "shared site," the character of this interaction throws doubt on the applicability of the phrase "shared."

The relations described above rarely become conflictual because while those involved share the same space they rarely share the same place. For the majority of pilgrims travelling in mobile enclaves the experience of holy places provides an intimate confirmation of the "reality" of those 
sites and of the pilgrims' personal relations to that "reality"; seeing the "real" place, without being forced to acknowledge the dissonance of others' interpretations of its reality, provides a sense of spiritual ownership that visitors take back to their places of origin. "Strangers" do not need literally to own the place because they do not live there. For them it is enough to experience the place and possess the knowledge of its reality.

Relation to place is very different for the monks and priests who move through and live in the immediate vicinity of the church. They see themselves as "owning" the holy sites in a much more literal way, and their conception of property-and of propriety (an etymologically related term) - can but be conflictual when others who are not of the same community have similar claims on the sites and different conceptions of the modes of deportment proper to them. The Franciscan, Armenian, and Greek Orthodox brotherhoods that care for their respective chapels within the building ${ }^{9}$ are brought into daily, often conflictual, contact with others whose senses of the site's significance, the legitimacy of its possession, and the appropriateness of ritual activities carried out therein differ on numerous points. Although these men cohabit the Holy Sepulchre and its neighborhood, they do not share locale and dispositions in the ways set out in the opening of this chapter. Jeff Halper describes the monasteries of the Christian Quarter in the late Ottoman period as each enclosing radically different lifeworlds, redolent of the nations of the monks' origins (Greece, France, Armenia) rather than of Jerusalem (Halper 1984). In many ways, at least in terms of self-sufficiency and ideological closure, the situations in the monasteries have not changed much. These insulated habitus produce literal neighbors who are, in effect, strangers (compare Duru and Bulle this volume). Unlike pilgrims who move past each other in the holy sites as migratory strangers, these hierophants are continuously forced to deal in "their" holy places with the presence of others who see those places as their own. For the monks and priests the holy sites in the "shared" space of the Anastasis or Holy Sepulchre are organically connected to the "pure" cultural spaces of the monasteries, and the presence of others in "their" spaces, much less the attempt of those others to claim the spaces as "their" own, is anathema. Whereas in the above cited situations of urban Indian traffic and Macedonian shrine sharing mutual investment in "common ground" gives rise to generally amenable and decorous ritual processes of negotiation over co-presence, in the Holy Sepulchre quotidian encounters between representatives of the respective churches are only prevented from routinely breaking into open violence by the regimen of the Status Quo, a system of spatial and temporal regulations initially imposed by the Otto- 
man state and currently maintained through fear of the open intercommunal warfare and state side-taking that its rejection would provoke. ${ }^{10}$

At the core of this conflict is not a simple issue of property ownership; actual property can - as the tenets of the Status Quo themselves assertbe shared, albeit through complex ritual regimes. We are instead looking at issues more closely tied to propriety, and through that to identity. Monks and priests associated with the Holy Sepulchre are able, when outside of domains demarcated as sacred, to relate to secular locals and even to members of other fraternities in non-conflictual-sometimes even amenable-ways. In contexts where religious identities are foregrounded, however, particularly in the choreographies of movements through the spaces of the holy sites, they become representatives of their particular religious community or, in the terms members of the Greek Orthodox Brotherhood of the Holy Sepulchre in the wake of a fight with Armenian monks over territory referred to themselves, as "defenders of the holy places" (fieldnotes, 31/12/84). In these contexts they, and the places they "protect," manifest the truth value of their church and its theology; their presence in the places, and the rituals they carry out there, are seen to "suture" their dogma and their orthopraxy toward real Christian revelation. The presence of others carrying out their apostate rituals and asserting their authority in those places constitutes what Laclau and Mouffe term an "antagonism" (Laclau and Mouffe 1985: 93-148)-literally a radical denial of their own assertions of identity as the sole vehicles of the true church.

In the case of antagonism ... the presence of the 'Other' prevents me from being totally myself.... (it is because a peasant cannot be a peasant that an antagonism exists with the landowner who is expelling him from his land). Insofar as there is antagonism, I cannot be a full presence for myself. (Ibid.: 125)

It is in this context that property, and the propriety of liturgical demeanor therein, becomes an issue of overarching concern. Concern with overcoming the antagonism presented by the presence of other belief communities is what motivates the insistence of the various religious communities that they "own" holy places and drives the demands of religious authorities worldwide that shrines and holy places be purged of heterodox practices and persons. The politics of the "rigid designator" is insistence that there is but one signified for the signifier. While this may appear to take the shape of straightforward demands for sole possession and inhabitance of a holy place, beneath that demand is the assertion of the truth value of a core identity and the insistence that no other 
representation can lay claim to the place where that identity manifests and celebrates itself. As a Greek monk told Nikos Kazantzakis when he visited the Anastasis in 1927: "this entire church belongs to us, the Orthodox. All the sacred shrines are ours.... [W] Armenians out.... Whatever the Latins tell you is a lie. All their shrines are fakes. I hope to God the day comes when we can throw them out" (Kazantzakis 1973: 153).

\section{Sveti Nikola/Hadir Bābā: Simultaneity of Place}

The concept of "property" functions in various ways in sites we refer to as "shared." In the case of Sveti Bogoroditsa Prechista, Muslims attending the monastery's church do not in any way dispute the Macedonian Orthodox Church's ownership of the site, visiting and using it with due deference to the nuns who live there. The Mother Superior and the majority of the nuns are in no way threatened by the presence of Muslims in the church, appreciating their generosity ("they give more than the Christians") and recognizing coexistence within the site as a welcome consequence of the long-term good relations of Muslims and Christians in the nearby town and surrounding countryside ${ }^{11}$ (see Bowman 2010: 209). In another Macedonian site I have written on, Sveti Nikola in Makedonski Brod, Sufi and Sunni Muslims praying in the church recognize the authority of the Orthodox caretakers, yet simultaneously associate the edifice and the tomb within with the Bektashi saint Hadir Bābā. Relations between the Christian visitors from the town and the Muslim visitors from neighboring settlements are cordial, and lubricated-as at Sveti Bogoroditsa-by the generosity of Muslims whose copious gifts are auctioned off to support the town's main church. Intriguingly, in the case of Sveti Nikola/Hadir Bābā mutual commitment by both communities to the continued sharing of the site is manifest in the simultaneous display of Sufi and Christian iconography within the church although, as I describe in my study of the site, perceived imbalances of display are able to give rise to aggrievement and potential hostility (Bowman 2010: 203-6). In both instances, as at the shrine of Haider Shaikh in Malerkotla described by Anna Bigelow, the local communities as well as the officiants at the religious sites commit themselves to maintaining forms of intercommunal cooperation in the shrines cognate with those taking place beyond their perimeters. Changes in that wider context of social relations, resulting in a breakdown of conviviality, can fracture that commitment, making way for one or the other community to attempt to force the other from the shrine; such an expulsion would mirror that 
effected in the surrounding social world. In other instances religious authorities, often backed by individuals of influence over local members of one or the other local religious community, may exploit frictions or fissures in the local community to push for the "purification" of a shrine. Even, however, in such instances the perceived sanctity of a site may be retained by the general population so that not only might members of the religious and ethnic communities banished from the site return, covertly and sometimes overtly, but also, as relatively amicable intercommunal relations in the surrounding locale are re-established, the site may again begin to be shared (see Bowman 2012: 215-17; see also Hayden this volume).

Shrines such as the Anastasis or Holy Sepulchre are very different insofar as rather than being perceived as properties of the local community (in both the sense of belonging to the local milieu and being characteristic of that social formation) they are presented as standing outside of their immediate context, belonging instead to ideologically constituted communities that may originate, and even reside, at a substantial physical and cultural distance from their literal site. For pilgrims visiting such sites from afar the holy places "belong" to them in a spiritual or devotional sense. They ideologically imagine the place as a spiritual possession that, once witnessed, can be "taken home" with them for meditation and validation, but their desire to literally possess the place rarely extends further than their wish to collect relics (oil, candles, carved olive wood crosses) to metonymically connect them with the place. For resident clergy, however, such holy places not only "belong" to their sects in a spiritual sense but must literally belong to their churches, since possession of the site both confirms their core identities as guardians of the holy places and authorizes and amplifies the sanctity of the site through their provision of appropriate liturgical practices (and their blockage of heterodox practices). Here the presence of others not only presents an integral challenge to their identities but also desecrates the sanctity of that central site (see Hassner 2009). "Tolerance" is anything but toleration in this context as it is in effect no more than enforced cohabitation.

\section{Strangers and Neighbors}

The distinction between "space" and "place" set out at the opening of this chapter is key to understanding the emergence of antagonism in shared sites. Space, as an encompassing container, is able to hold a number of entities without their having any relation aside from that of con- 
tiguity. Place, as a site of inhabitance, can contain differentiated bodies, but these, by sharing place, enter into relations with each other. Thus, on the one hand pilgrim groups, converging on the same holy sites from different places of origin, are able to flow around and past each other, each pursuing their own realizations of their own envisionings of the significance of the sites they temporarily occupy. The "place" each group inhabits is effectively rendered discontinuous with the "places" of others, and interaction is kept minimal and impersonal. On the other hand, neighbors of different sectarian affiliations can meet in local holy places, engaging with each other through media of negotiation and mutual recognition analogous to those they use in their everyday interactions outside of holy ground. Here each group simultaneously occupies the same place and must engage modes of mutual accommodation, rendering that coexistence as non-conflictual and as mutually beneficial as possible. In the instance of the Holy Sepulchre or Anastasis, a situation not unlike others worldwide in which religious powers work to present a site as a pure signifier of an exclusive identity that must be defended from the pollution of other forms of worship, ${ }^{12}$ two or more communities attempt to construct, and inhabit (literally and ritually), exclusive places at the same time in coterminous spaces. Such cohabitation is, in terms of their respective discourses, an impossibility, and thus the presence of the other presents a literal antagonism that must either be overcome through expulsion or succumbed to by withdrawal. The "stand-off" that is the current status quo effected by the Status Quo is an ideological impossibility, and the Holy Sepulchre/Anastasis will remain a flashpoint, surrounded by the tinder of cadres of ideologically motivated monks, until either a discursive shift in the respective theologies replaces antagonism with fraternity or one group successfully expropriates and "cleanses" the site.

In the post-Ottoman sphere, where conceptions of "nationalist" identity increasingly impose themselves on domains where "national" identities had served as markers of nominal difference within mixed communities, ${ }^{13}$ places that had been shared-whether secular or sacred-are transformed into the exclusive properties of ethno-nationalist groupings. Sharing, or even mixing, is there rendered contentious, and local events in which individuals with different allegiances clash come to be read more widely as indubitable signifiers of irresolvable inter-communal antagonisms. Once such a discursive shift has taken place, and shared sites have been transformed into terrains on which struggles for possession take place, it becomes increasingly impossible to imagine contemporary cohabitation and sharing, and the image of coexistence fades into a utopian fantasy of a distant "Ottoman" past. 
Glenn Bowman is Professor of Socio-historical Anthropology at the University of Kent, Canterbury. He has conducted fieldwork in Jerusalem, the Occupied West Bank, Yugoslavia, and Macedonia, on how people in communities marked by diversity-particularly by different religious affiliations-manage for the most part to live together but, in certain circumstances, divide into antagonistic groupings that war with each other. Since 2004 he has researched "walling," i.e., processes to block any contacts between communities, in Israel and Cyprus. He is a former editor of the Journal of the Royal Anthropological Institute, the author of numerous articles and the editor of Sharing the Sacra: The Politics and Pragmatics of Inter-Communal Relations around Holy Places (Oxford: Berghahn, 2012).

\section{Notes}

1. Place, n.1. OED Online. March 2013. Oxford University Press (accessed 19 April 2013), see also Casey (1997), Casey (2002), and Massey (2005).

2. The concept of habitus, itself a Latin translation of the Greek hexis, has a long genealogy stretching back nearly two and a half millennia from Bourdieu's Outline of a Theory of Practice (1977 [orig. 1972]) and Logic of Practice (1990 [orig. 1980]) via Mauss' Les Techniques du Corps (1935, see also 1979) and Aquinas's Summa Theologica (la2ae, 49-54) to Aristotle's Nichomachean Ethics (1098b33).

3. See too the essays collected in Albera and Couroucli (2009 and 2012) and Bowman (2012).

4. "Situational identity" is a concept generally assumed to have been generated by, but not specifically used in, Erving Goffman's theory of the dramaturgical construction of social identity developed in The Presentation of Self in Everyday Life (1959). Max Gluckman had, however, elaborated the concept of "situational selection" in 1940 whereby individuals shape their behaviors, in different social contexts, so as to conform to the values and practices of groups they associate with there: "the shifting membership of groups in different situations is the functioning of the structure, for an individual's membership of a particular group in a particular situation is determined by the motives and values influencing him in that situation. Individuals can thus live coherent lives by situational selection from a medley of contradictory values, ill-assorted beliefs, and varied interests and techniques" (Gluckman 1958 [orig. 1940]: 26).

5. Despite the difference in name the "place" of the crucifixion, tomb ("sepulchre"), and resurrection ("anastasis") of Jesus is established at the heart of New Testament biblical narratives so that that "place" can be seen to function as a rigid designator even when ideas of its actual location can differ by several hundred meters (as with the Anglican Garden Tomb). 
6. The Greek Orthodox Katholicon was, however, normally closed to all but the Greek Orthodox.

7. These strategies were carried out throughout Holy Land pilgrimages and, one suspects, across other forms of organized travel-see Schmidt (1979).

8. Those whose experiences do not live up to their expectations, or in fact seem to refute them, may be impelled to deny that the sites are the "real" sites (either because the real sites are elsewhere or because they have been effaced by time) or may be forced to question their previous assumptions and beliefs.

9. The Coptic, Syrian, and Ethiopian Orthodox, who possess chapels because of historic precedent, are small communities with little political or economic power, and their presence in the church is rarely challenged by the dominant religious communities (although they fight among themselves over the territories they do control; see Bowman 2011: 389-91).

10. See Fisher-Ilan (2004) for one of many examples, Cohen (2008) and Bowman $(2011,2014)$ for different interpretations of how and why the Status Quo is maintained.

11. Although one university-trained novice, recently relocated to the monastery from Skopje, expressed hostility toward Muslim visitors, claiming they were planning to "steal" the church (Bowman 2010: 209).

12. A salient example is the 1992 destruction by Hindu activists of the Babri Mosque at Ayodhya in order to clear the site for the construction of the Sri Ram Janam Bhumi Temple commemorating the birthplace of Lord Rama (an avatar of Vishnu).

13. See Bowman 2015 as well as my discussion of the Titoist treatment of "national" versus "nationalist" identities in Bowman (2003: 229-30).

\section{References}

Albera, Dionigi, and Maria Couroucli, eds. 2009. Religions traversées; Lieux saints partagés entre chrétiens, musulmans et juifs en Mediterranée. Arles: Actes Sud.

- 2012. Sharing Sacred Spaces in the Mediterranean: Christians, Muslims, and Jews at Shrines and Sanctuaries. Bloomington: Indiana University Press.

Assayag, Jackie. 2004. At the Confluence of Two Rivers: Muslims and Hindus in South India. New Delhi: Manohar.

Bigelow, Anna. 2010. Sharing the Sacred: Practicing Pluralism in Muslim North India. Oxford: Oxford University Press.

Bourdieu, Pierre. 1977 [orig. 1972]. Outline of a Theory of Practice, trans. Richard Nice. Cambridge: Cambridge University Press.

— 1990 [orig. 1980]. The Logic of Practice, trans. Richard Nice. London: Polity Press.

Bowman, Glenn. 1988. "Tales of the Lost Land: Palestinian Identity and the Formation of Nationalist Consciousness." New Formations 4: 31-52. 
1994. "A Country of Words': Conceiving the Palestinian Nation from the Position of Exile." In The Making of Political Identities, ed. Ernesto Laclau, 138-70. London: Verso.

_ 2003. "Constitutive Violence and the Nationalist Imaginary: Antagonism and Defensive Solidarity in 'Palestine' and 'Former Yugoslavia.' Social Anthropology XI: 319-40.

_- 2010. "Orthodox-Muslim Interactions at 'Mixed Shrines' in Macedonia." In Eastern Christians in Anthropological Perspective, ed. C. Hann and H. Goltz, 195-219. Berkeley: University of California Press.

—_. 2011. “In Dubious Battle on the Plains of Heav'n': The Politics of Possession in Jerusalem's Holy Sepulchre." History and Anthropology XXII: 371-99.

- 2012. "Nationalizing and Denationalizing the Sacred: Shrines and Shifting Identities in the Israeli-Occupied Territories." In Sacred Space in Israel and Palestine: Religion and Politics, ed. Y. Reiter, M. Breger and L. Hammer, 195-227. London: Routledge.

—_ ed. 2012. Sharing the Sacra: the Politics and Pragmatics of Inter-communal Relations around Holy Places. New York: Berghahn Books.

_- 2013. "Review of Anna Bigelow, Sharing the Sacred: Practicing Pluralism in Muslim North India." Comparative Studies in Society and History 55: 507-9.

- 2014. “The Politics of Ownership: State, Governance and the Status Quo in the Anastasis (Holy Sepulchre)." In Choreographies of Shared Sacred Sites, ed. Elazar Barkan and Karen Barkey, 202-40. New York: Columbia University Press.

—_ 2015. "Lieux Saints Partagés: An Analytical Review". Medieval Worlds 1: 2 (Empires: Elements of Cohesion and Signs of Decay), 89-99.

Bringa, Tone, dir. 1993. We Are All Neighbours. Disappearing World. Debbie Christie, Ser. Dir. Granada Television.

Casey, Edward S. 1997. The Fate of Place: A Philosophical History. Berkeley: University of California Press.

- 2002. Representing Place: Landscape Painting and Maps. Minneapolis: University of Minnesota Press.

Cohen, Raymond. 2008. Saving the Holy Sepulchre: How Rival Christians Came Together to Rescue Their Holiest Shrine. New York: Oxford University Press.

Fisher-Ilan, Allyn. 2004. "Dozens Hurt as Clerics Clash in Jerusalem Church.” In AlertNet: Reuters Foundation.

Gluckman, Max. 1958. The Analysis of a Social Situation in Modern Zululand. (Rhodes Livingston Paper No. 28 [originally in Bantu Studies 14 (1940) pp. 1-30]). Manchester: Manchester University Press.

Goffman, Erving. 1959. The Presentation of Self in Everyday Life. Garden City, NJ: Doubleday Anchor.

Halper, Jeff. 1984. "On the Way: the Transition of Jerusalem from a Ritual to a Colonial City (1800-1917)." Urban Anthropology XIII: 1-32.

Hassner, Ron. 2009. War on Sacred Grounds. Ithaca: Cornell University Press. 
Kazantzakis, Nikos. 1973 [1961]. Journeying: Travels in Italy, Egypt, Sinai, Jerusalem and Cyprus, trans. Themi Vasils and Theodora Vasils. Boston: Little, Brown and Company.

Kripke, Saul. 1980. Naming and Necessity. Oxford: Blackwell.

Laclau, Ernesto, and Chantal Mouffe. 1985. Hegemony and Socialist Strategy: Towards a Radical Democratic Politics, trans. Winston Moore and Paul Cammack. London: Verso.

Lockwood, William. 1975. European Moslems: Economy and Ethnicity in Western Bosnia. (Studies in Anthropology). New York: Academic Press.

Massey, Doreen. 2005. For Space. London: Sage Publications.

Mauss, Marcel. 1935. "Les Techniques du corps." Journal de psychologie normale et pathologique XXXII: 271-93.

— 1972 [1950]. A General Theory of Magic, trans. Robert Brain. London: Routledge and Kegan Paul.

— 1979 [1935]. "Body Techniques." In Sociology and Psychology: Essays, trans. Ben Brewster, 95-123. London: Routledge and Kegan Paul.

Schmidt, Catherine. 1979. "The Guided Tour: Insulated Adventure." Urban Life 7: 441-68.

Sorkin, Michael. 1999. "Introduction: Traffic in Democracy." In Giving Ground: The Politics of Propinquity, ed. J. Copjec and M. Sorkin, 1-15. London: Verso.

Vološinov, V. N. 1973 [1929]. Marxism and the Philosophy of Language, trans. Ladislav Matejka and I. R. Titunik. Cambridge, MA: Harvard University Press.

Žižek, Slavoj. 1989. The Sublime Object of Ideology (Phronesis). London: Verso. 


\section{Index}

A

A-Ram, 243, 245

Abasıyanık, Sait Faik, 163-64.

Abdul Mecid, Sultan, 45

Agamben, Giorgio, 240

Agos (newspaper), 215, 226, 231

agriculture, 26, 44, 46-48, 51, 55n8

cultivation, 44, 45, 47, 48, 51, $55 \mathrm{n} 8$

agro-sylvo-pastoral system, 47

irrigation, 47-48, 51, 55n9

sharecropping, 48

shifting cultivation, $47-48,55 \mathrm{n} 8$ subsistence, 44

AK Party (AKP, Turkey), 171, 209, 211, 224, 230

Ak-yazul Baba tomb (Bulgaria), 75-76

Akgönül, Samim, 208, 211, 227, 230n 5

Aktamar, 218-19

Aleksander Nevsky Cathedral (Sofia), 75

Alevis, 158, 165-66, 168-69, $171-72,175,208$

Alexandria, 29, 129-31, 134-36, 145, 151-52

Allerton, Catherine, 20

Altınay, Ayșe Gül, 213, 241n14, $241 \mathrm{n} 16$

Anadolu Kültür, 217, 232

Anastasis (Jerusalem). See Church of the Holy Sepulchre apology campaign (Turkey), 213 Arab Israelis, 245

Arendt, Hannah, 212-13, 222
Armenians

Armenia-Turkey Cinema Platform, 232

Armenian Club (Nicosia), 118-19, 122

Armenian Orthodox, 208, 225

in Istanbul, 28, 215-16, 219, 220, 223-26, 229, 230n2

in Turkey, 4, 212, 217

Article 301 (Turkish Penal Code), 213

ASALA (Armenian Secret Army for the Liberation of Armenia), 221, 223, 233n38

Assayag, Jackie, 260-61

Ayık, Vartkes Ergün, 218

B

Balkan wars. See Yugoslavia, war

Banya Başı Mosque (Sofia), 74-5

Barkey, Karen, 12-13, 15, 60

Bartholomew, Patriarch (Greek

Orthodox), 233

Baydemir, Osman, 219, 232

Bedrosyan, Raffi, 218

Bethlehem, 244-45

Bentley, Eric, 133, 153

Bektashi

religious order, 76-78, 99

saint, 77, 269

Bigelow, Anna, 260-62, 269

Bilaniuk, Laada, 199, 201

Black Mosque (Sofia), 74-5

Bosnia-Herzegovina, 181-92,

194-96, 199-200

Herzegovina, 186, 194, 196 
Bosnian language, 185, 189, 191, 200 and Bosniak, 191, 193, 197

Bourdieu, Pierre, 172, 259-61, 272n2

Boykov, Grigor, 82n2

Brahim Baba (Crete). See Ibrahim Baba spring

Bringa, Tone, 1-2, 262

Brubaker, Rogers, 31n10, 79-80

Buffer Zone (Nicosia), 107-8

Burgaz Island, 7-8, 29, 159-75

Bursa (Turkey), 59-60, 62-63

Butler, Judith, 134

C

Çağaptay, Suna, 61, 63

Candea, Mattei, 19

Cathedral Church of the Holy Cross, 218

Cathedral of the Holy Mother of God (Plovdiv), 73-4

centrality (concept), 73-74, 81n1

Çetin, Fethiye, 213-14, 222

My Grandmother (Anneannem), 213

Chalom (character), 129-32, 135, 138, 144-49, 151n10, 152n22, 153n32, 154n35

Chau, Adam Yuet, 164

Chicago School, 240, 251

Christodoulou, Demetrios, 42, $48-49$

Church of the Holy Mother of God Most Innocent, 263-64, 269

Church of the Holy Sepulchre (Jerusalem), 69, 266-68, 270-71, 272n5

Church of the Resurrected Christ (Serbia), 66

"Citizen Speak Turkish" campaign, 209

civil inattention, $8,27,30,248,251$, 255

coexistence, $3-12,14,21-30,31 \mathrm{n} 12$, 41-44, 53-54, 62, 67, 80-81, 8687, 92-94, 97, 100-2, 108-110,
121, 129-30, 135-36, 144, 148-49, 152n21, 157-59, 161, 164, 167-71, 175, 180, 186, 208, 211-12, 21920, 222, 227, 229, 249-50, 252, 258, 269, 271

peaceful, 4, 9-11, 23, 28, 41, 62, 80, 86-87, 93-94, 97, 100, 102 cohabitation, $8,14,144,258,260$, 270-71

Cohan, Steven, 150n2

commensality, 2, 154n33, 258

communities of confidence, 8,30 , 248, 252

Constantinou, Costas M., 2, 9, 21

constructive ambiguity, 21-23,

25-27, 29, 46, 121, 249

contiguity, 29-30, 240-41, 248-49, 251-53, 262

conviviality (convivencia), 7, 158-61, 164, 166-75, 176n1, 269

co-presence, 8, 29, 120, 239-41, 250-51, 267

cosmopolitanism, 6-7, 91-92, 102-3, 151n13, 160, 176n1

Cowan, Jane, 176n3

Cretan Question, 97

Croatian language, 181, 183-84, 188-98, 200. See also SerboCroatian language cultural fundamentalism, 180 cultural property, 261

Cyprus, 1, 3, 10, 19-20, 22, 28, 31n11, 41-44, 46-52, 54, 55n8, 55n10, 56n15, 64, 79-80, 108-9, 112-14, 116, 123, 168-70, 210

D

Demirtaş, Abdullah, 218, 232n34

Derinkuyu (Turkey), 79

Dersim (Tunceli), 176n7, 214, 231n17

Dink, Hrant, 215-216, 224, 231n19

Hrant Dink Foundation, 217, 231n18, 232n30

diplomacy, everyday, 9, 21, 23, 25, $27,30,42,101,220,222,249,251$ 
domovina, 29, 193-94

dönme, 176n4

Doumanis, Nicholas, 5-6, 10, 25-26, 30n3, 31n8, 159

Druze, 245

Dumont, Louis, 60

E

effendi masculinity, 134-35, 152n22

effendiyya, 135

enclaves, Turkish Cypriot, 52

endogamy, 4, 61

Erdoğan, Recep Tayyıp, 212, 225, $231 \mathrm{n} 10$

Erzincan, 165-66, 169, 215

European Court of Human Rights, 53, 225

European Union (EU), 77, 171, 207

\section{$\mathbf{F}$}

farce, 29, 132-33, 143, 153n28

bedroom farce, 133-34, 140, 146

Victorian, 152n16

vs. burlesque, 133

Fish, Stanley, 230n8

Ford, Richard Thompson, 134

Forty Martyrs Church (Sofia), 75

Foundations Law. See Law of Foundations

\section{G}

giving ground, 8, 30, 258-60

Goffman, Irving, 29-30, 255n15, 272n 4

Gluckman, Max, 272n4

gray spaces, 249-50

Güler, Ara, 224

Ara Café, 224

Gültekin, Mihran, 231n17

H

Habitus, 120, 172, 197, 252, 259-63, 267, 272n2

Hadir Bābā tomb (Macedonia), 77, 269
Hagia Sophia (Istanbul), 66, 68

hali, 45

halloumi, 21, 114-15

Halper, Jeff, 267

Hammett, Dashiell, 152n20

Hanson, Ellis, 134

Harmanyeri, Ece, 228

Hasluck, F. W., 62, 67, 75-76, 78

Hassner, Ron, 81n 1

Hatay, Mete, 10, 80

Hebron, 244

heteronormativity, 142-43

Hocart, A. M., 20

Holy Sepulchre, Church of

(Jerusalem), 69, 266-71

Horden, Peregrine, 46, 48

hoşgörü, 157, 175

hospitality, 9, 19-21, 24, 26-27,

32nn18-19, 42, 167, 249, 252

huzur, 9, 15

I

Ibrahim Baba spring (Crete), 93

Ibrahim Pasha Mosque (Bulgaria), 173

Immovable Property Law of 1946

(Cyprus), 49

intercommunality, 5, 25-26

interdependence, 18, 27-28, 240-41, 249-50

intertemporality, 68-70

Intifada, 238, 245 "White Intifada," 245

Iraklio, 6, 87-89, 92, 95-96, 99, 102, 103 n. 1

Islam, 60-63, 79, 94, 96, 153n27, 171,

176n4, 208-9, 211, 214, 219

Islamism, 171, 209

Islamist, 211, 230n1

Islamized Armenians, 213-14, $231 n 18$

Sunni, 24, 77-78, 158, 160, 164-65, 170, 172-73, 208, 210, 263, 269

Shafi'i, 160, 173 
Israeli-Palestinian conflict, 238, 250, 252

Israeli settlements, 243, 245-248, $251,254 \mathrm{n} 7$

Istanbul, 6-7, 17, 28-29, 66, 68, 160-62, 165-66, 169, 171-73, 207, 210-12, 215-21, 223-27, 229

Armenian community. See Armenians, in Istanbul Greek community, 6, 162-66, $168,170-71,173-75,176 n 6$ riots (1955), 161, 168-70, 176 n 5,210

J

Jacob, Wilson, 134-35, 152n22 Jerusalem, 69, 120, 238-45, 247-52, 254-55, 266-67

East, 238-39, 242-44, 247, 249, 251-52, 254

Municipality of, 240

tramway, 30, 248, 251

Jordan Valley, 246

Justice and Development Party

(Turkey). See AK Party

$\mathbf{K}$

$k a d l, 44$

Kardam, Nükhet, 214-15

Kardjali (also Karcali), 83-84

Kasim Pasha Mosque, 64

al-Kassar, 'Ali, 131-32, 135, 151n11, 152n16

Kavala, Osman, 217

Kaya, Ayhan, 228

Kazantzakis, Nikos, 93-94, 269

Kemalism, 171, 209, 209-11, 214

Kicevo (Macedonia), 263-64

komşuluk (komšiluk), 14, 16-18, 23, 31n15, 158, 181, 199n1

Koneska, Elizabeta, 77-78, 263

Kosovo, 79

Kripke, Saul, 265

Kurds, 158, 160, 168-69, 208-9, 213, 215, 217, 219-20, 224, 228
$\mathbf{L}$

labor of peace, 9, 17, 21-22, 25, 27, 46, 158, 167, 252

Laclau, Ernesto, 268

Lafi, Nora, 7

land fragmentation, 47-48, 50. See also agriculture and inheritance, 41, 47, 49

Land Reform of 1946 (Cyprus), 49-50

language ideologies, 181, 201n15

Law of Foundations, 209, 227

Law of Settlement (1934), 209

Law of Surnames (1934), 210

Levantine

aesthetics, 29, 136, 144-145, 148

ethics of coexistence, 136, 144

identity, 8, 29, 133-136, 148, 152nn19-21

idiom, 8, 29, 130, 133-135, 143, $152 \mathrm{n} 24$

queerness and, 130, 134, 152nn19-21

"liberation churches," 74

linguistic nationalism, 196

linguistic purism, 190

Lowry, Heath, 78

M

mahalle, 9, 14-15, 17, 22, 24, 99, 103n5, 107, 117, 121, 158. See also neighborhood (concept)

Malerkotla, 260-62, 269

manuals, ethics, 16, 32n17

Market Mosque (Sofia), 74

Massey, Doreen, 110, 120, 125n16

Mauss, Marcel, 260-62, 272n2

Melnyk, Svetlana, 199, 201

melodrama, 132-33, 152n18

and the nation, 133

Menicucci, Garay, 152n24

Mesrob II, Patriarch of Istanbul

(Armenian Orthodox), 218, 224, 233n 44

metruk, 45 
micro-region, 46-48

millet, 4, 8, 11-12, 92, 95, 97-98, 157-58, 233n40

Mills, Amy, 6, 211-12

miri, 44-45

Mishor Adumim, 246

mizrahi (pl. mizrahim), 143, 250 and mashriqi, 143

Mizrahi, Togo, 129-36, 143, 150n3, 151nn5-6, 151n9, 151nn11-12, 151n14, 152nn19-22, 153n24, 153n27, 153n30, 153n32, 154n33 Doctor Farahat, 130, 132, 13643, 146-47, 150n3, 151n6, 151n12, 151n15, 153n30

Mistreated by Affluence, 129-30, 136, 138, 143-44, 146, 148-49, 150n 5, 151n 9, 153n25, 153n32, 154n33, 154 n 35

modernization, 28, 43, 49-50, 89

Mostar, 9, 29, 181, 185-96, 198, $201 n 16$

bridge, 9

Gymnasium, 29, 181, 185-96, 198, 201n16

Mouffe, Chantal, 268

Movement for Rights and Freedoms (Bulgaria), 74

mülk, 45

Muradiye Mosque (Bulgaria), 73

\section{$\mathbf{N}$}

narod, 189, 193

neighbor's right, 16

neighborhood (concept), 2-3, 5 , 8-9, 14-21, 24-26, 31n15, 41-43, 45-48, 53, 54n1, 71, 101, 107, 117-18, 121, 148, 199n1, 241, 245, 249-50, 253, 259-62.

neighborliness (also see komşuluk), $9,14,16-19,21,23,26-28,30$, $31 n 15,42$

Nicosia, 8, 27, 51, 107-10, 114-20, $122,124 \mathrm{n} 7,125 \mathrm{n} 10,249$
Nişanyan, Sevan, 233n36

nostalgia, 4, 6-7, 10, 17, 26, 88, 91, $94,98,103,123,151 n 13,159-60$, 210-11 cosmopolitan, 6-7, 88, 151n13, 159, 210-11 imperialist, 91 neo-Ottoman, 7 post-Ottoman, 17, 159

Nusseibeh, Sari, 252, 255n19

O

Obrochiste (Bulgaria), 75

Öktem, Kerem, 212, 231n14

örf, 44

OSCE (Organization for Security and Co-operation in Europe), 188, 191-92, 196

Oslo Accords, 71, 265

Ottoman Empire (also Ottomans), 3-4, 8, 11-15, 17, 22, 24, 31n8, 43, 45, 55n10, 59-60, 62, 64-67, 72-73, 87, 90-92, 98, 157-59, 168, 171, 176n3, 183, 210-15, 228 Ottoman Land Code, 45-46, 49, 55 Overing, Joanna, 166-67

P

Palestinian territories, 239, 253

Pantopolio/Bandabulya, 113, 115-16, 123, 125n12

Park, Robert, 240

Partition (South Asia), 3, 261

Pasieka, Agnieszka, 6

Passes, Alan, 166-67

Peasants, 43-44, 47, 49-50, 53, $56 \mathrm{n} 12,60$

Pecs, 59, 63-64

Peleikis, Anja, 25-26 perceptibility, 72-74 performance (concept), 8, 20, 26-27, 29-30, 134-136, 141, 149, 167, $181,186,196-198$ language, 181, 186, 193, 197-8 performativity, 18, 26, 29, 134-36 
Philliou, Christine, 211

Pisgat Zeev, 246-47, 252

place (concept), 2-4, 7-8, 16-18, 21, $26,30,59,71,80,109-11,122-23$, 159-60, 167, 171-172, 175, 217, 241, 249, 252, 258-260, 265-271, 272n1, 272n5

Plovdiv (Bulgaria), 72-74

population exchange, 79 of $1923,66,91,98,159,169$, $176 \mathrm{n} 6$

Purcell, Nicholas, 46, 48

Q

Qalandiya, 243-44

queer (including queerness, queering), 129-30, 133-34, 136, 138, 141, 149, 150n2, 152nn19-21 theory, 134 and gender identity, 129, 138

$\mathbf{R}$

Radcliffe-Brown, A. R., 69

Razgrad (Bulgaria), 73

Reilly, James A., 211

religioscape, $24,67,71,74-75$, 7881

Republican People's Party (CHP), 176n4, 207, 209

Republika Srpska, 79, 182

rigid designator, 265-66, 268, 272n5

Ring, Laura, 22-23, 26, 167, 250

riot, in South Asia, 13, 30n2

Robbins, Joel, 60, 91

Rodrigue, Aron, 6, 13

Rosaldo, Renato, 88

\section{S}

Saint Atamas tomb (Bulgaria), 76

Saint Barnabus Monastery (Cyprus), 79

Saint Mamas Church (Cyprus), 79-80

Saint Mary of the Mongols Church (Istanbul), 66
Saint Nedelya Church (Sofia), 74-75

Saint Nicholas Church in Chania, Crete, 65 in Famagusta, Cyprus, 64 in Makedonski Brod, Macedonia (also Sveti Nikola), 64-65, 73, 77

Saint Sophia Mosque (Cyprus) (also Aya Sofya), 64, 113, 117, 125n13

Sarafian, Ara, 218

Sarajevo, 16, 59, 72, 195, 263

scale (concept), 9, 17, 19, 24-25, 71,

$78,80,158,252-53$

scale-free abstraction, 19

Schmitt, Carl, 254n1

security barrier (Israel), 238-39, 242-43, 245. See also separation wall (Israel)

separation wall (Israel), 238-42, 245,249 . See also security barrier (Israel)

Serbo-Croatian language, 181, 183-84, 195, 198, 200

Sharia, 44-45

Shryock, Andrew, 24-25, 32n18

Simmel, Georg, 8, 27, 108, 120, 123, 125n17, 240-41, 249

Sinclair-Webb, Emma, 230n1

situational identities, 261, 272n4

smuggler (as stranger), 251

social stratification, 44,53

Sofia (city), 66, 74, 78

Sorabji, Cornelia, 16

Sorkin, Michael, 258-59, 264

Sourp Giragos Cathedral (Diyarbakır), 218-19, 232n34 sovereignty, 9, 18-21, 24-25, 240, 252

multi-scalar, 8, 18, 24, 119 space (concept), 2-4, 8-9, 12-14, $16,19,21,24-25,27-30,31 n 14$, 41-2, 59-63, 66-67, 71-73, 78-81, 81n1, 93, 98-102, 107-11, 118-19, 121, 125n8, 158-59, 161, $164,167-68,175,180,192,198$, 


$$
\begin{gathered}
216-17,239,243-45,247-53, \\
258-59,263-68,270-71 \\
\text { post-Ottoman, 3-4, 9, 16, 21, } \\
25,59-61,78,159,175
\end{gathered}
$$

spatial governmentality, 182, 186, 200n6

Spivak, Gayatri, 222

Status Quo, the (Jerusalem), 267-68, 271, 273n10

stranger (concept), 20-22, 250, 265, 267

the (Simmel), 8, 27, 108, 120, 123, 125n17, 249-251

structural functionalism, 69

Suciyan, Talin, 212

sulh, 6, 9, 15, 22

Sveti Bogoroditsa (Plovdiv). See Cathedral of the Holy Mother of God

Sveti Bogoroditsa Prechista

(Bulgaria). See Church of the Holy Mother of God Most Innocent Sveti Nikola Church (Macedonia), 77, 269

\section{$\mathbf{T}$}

Tal'at Harb, Muhammad, 131

Tamari, Salim, 250

\section{Tanzimat, 74}

Tarnovo, Veliko, 60

threshold (house), 21, 23-24, 26-27

tolerance (also toleration), 5-7, 11-13, 17, 67, 157-159, 161, 164, 168-71, 175, 186, 208, 211, 228-229, 244, 260, 270 antagonistic, 5, 31n5, 60, 67 Ottoman, 11-12, 17, 31n12, 31n8, 208, 218

traffic (concept), 258-59, 266-67 trapped minority, 189, 201n17
Treaty of Lausanne, 98, 157, 169, 208-9

Trigg, Dylan, 108

Trilye (also Triglea), 63, 66

Tunceli, 214, 231. See also Dersim

Turkification, 208-9, 223, 226

Turkocretan, 87, 90-91, 95, 97-99, 101-102

$\mathbf{U}$

Umm Kulthum, 131, 151n8

Uzundzhovo (Bulgaria), 79

V

vaklf (pl., evkaf), 45, 53, 116, 124n6

Valtchinova, Galia, 14

Van, Governor of, 218

Varlık Vergisi (Wealth Tax, Turkey), 168, 176n4, 210

Varshney, Ashutosh, 27

W

Wealth Tax. See Varlık Vergisi

West Bank, 243-44, 254nn6-7

Wirth, Lewis, 240-1

$\mathbf{Y}$

Yiftachel, Oren, 249-50

Yllmaz, Fikret, 15

Yugoslavia, 183-184, 186, 190-1, 196, 200n10 war (also Balkan wars), 1, 9, 31n15, 180, 186

\section{$\mathbf{Z}$}

Zagreb, 193-94

Zaim, Derviş, 1-2

Zaza, 160, 166, 172

Žižek, Slavoj, 98, 265 